\title{
Cost-Effective Cementitious Material Compatible with Yucca Mountain Repository Geochemistry
}

\section{December 2004}

Prepared by

Les Dole ${ }^{1}$

Catherine Mattus ${ }^{1}$

Mostafa Fayek ${ }^{2}$

Lawrence M. Anovitz ${ }^{1}$

Juan J. Ferrada ${ }^{1}$

David J. Wesolowski ${ }^{1}$

Don Olander ${ }^{3}$

Don A. Palmer ${ }^{1}$

Lee R. Riciputi ${ }^{1}$

Lætitia Delmau ${ }^{1}$

Sergé Ermichev ${ }^{4} *$

Vyacheslav I. Shapovalov ${ }^{4}$.

${ }^{1}$ Oak Ridge National Laboratory,

${ }^{2}$ University of Tennessee, ${ }^{3}$ University of California Berkeley,

${ }^{4}$ MINATOM VNIIEF, Sarov, * funded by ISTC programs 



\title{
COST-EFFECTIVE CEMENTITIOUS MATERIAL COMPATIBLE WITH YUCCA MOUNTAIN REPOSITORY GEOCHEMISTRY
}

December 2004

\author{
Les Dole $^{1}$, Catherine Mattus ${ }^{1}$, \\ Mostafa Fayek ${ }^{2}$, Lawrence M. Anovitz ${ }^{1}$, \\ Juan J. Ferrada ${ }^{1}$, David J. Wesolowski ${ }^{1}$, Don Olander ${ }^{3}$, \\ Don A. Palmer ${ }^{1}$, Lee R. Riciputi ${ }^{1}$, Lætitia Delmau ${ }^{1}$, \\ Sergé Ermichev ${ }^{4}$, Vyacheslav I. Shapovalov ${ }^{4} *$ \\ ${ }^{1}$ Oak Ridge National Laboratory, \\ ${ }^{2}$ University of Tennessee, ${ }^{3}$ University of \\ California Berkeley, ${ }^{4}$ MINATOM VNIIEF, \\ Sarov, *funded by ISTC programs.
}

Contact: Les Dole, 865-576-4319, dolelr@ornl.gov, Nuclear Science and Technology Division, Oak Ridge National Laboratory

\author{
Prepared by \\ OAK RIDGE NATIONAL LABORATORY \\ P.O. Box 2008 \\ Oak Ridge, Tennessee 37831-6254 \\ managed by \\ UT-Battelle, LLC \\ for the \\ U.S. DEPARTMENT OF ENERGY \\ under contract DE-AC05-00OR22725
}





\section{TABLE OF CONTENTS}

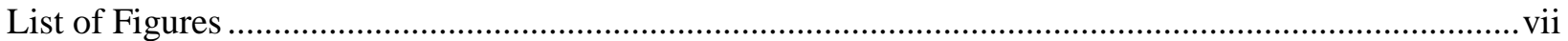

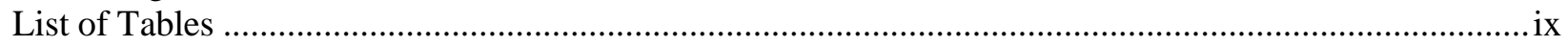

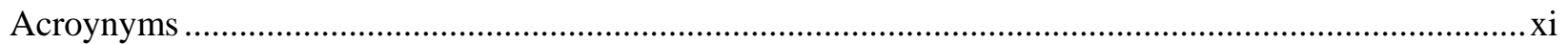

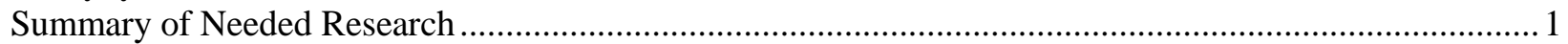

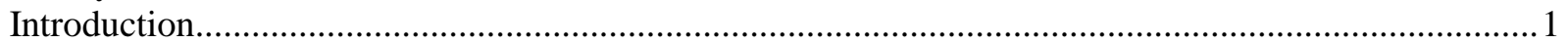

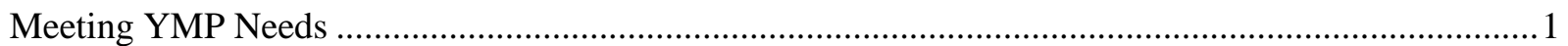

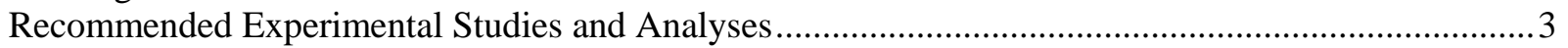

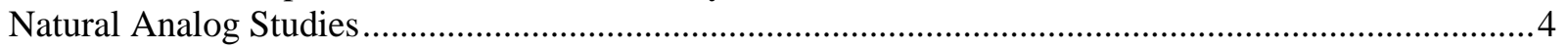

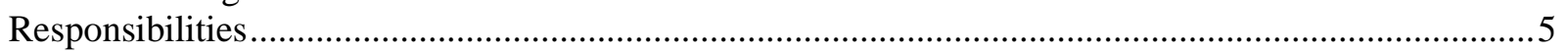

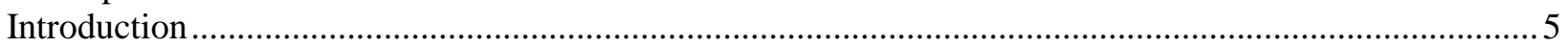

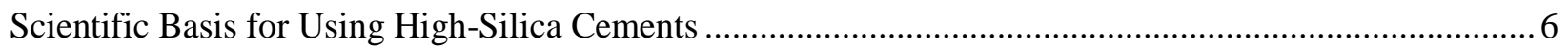

Yucca Mountain Project Concerns with the Uses of Cements in the YM Repository ............................6

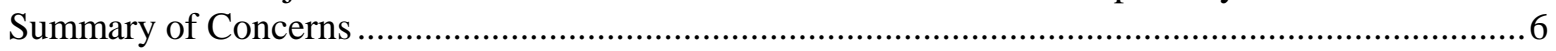

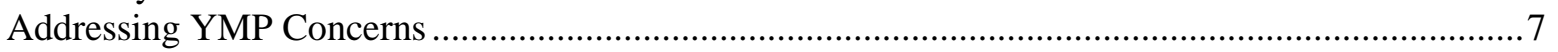

Silicates Suppress the Formation of Calcium Hydroxide ......................................................... 7

Fine Pore Distribution in High-Silica Cements Reduces the Release of Moisture ....................... 19

Silica-Saturated Cement Leachates Will Not Dissolve Adjacent Vitreous Tuff.............................22

Pozzolanic Additives Are Water-Reducing Agents and Minimize the Need for Surfactants ........22

High-Silica Cements Limit the Bioavailability of Nutrients....................................................23

Natural and Anthropogenic Analogs Can Predict Long-Term Performance ................................24

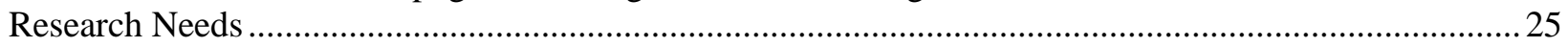

Need 1: Develop and Test Cost-Effective, High-Silica Cementitious Materials for Construction of

Yucca Mountain (YM) Inverts, Drift Liners, and Bulkheads............................................................25

Preliminary Analysis of Potential Cost Savings .........................................................................29

Potential Economic Impacts of Substituting a Conservative 100-mm Thickness of Fiber-

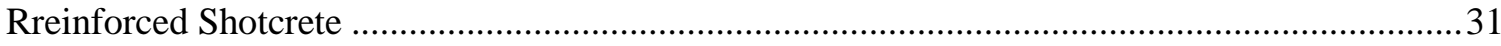

Economic Impact of Using a More Likely 50-mm Thickness of Shotcrete...................................31

Summary and Comparisons of Preliminary Economic Analyses ................................................ 31

The Laboratory Tasks to Support these Objectives .......................................................................... 31

Need 2: Establish Long-Term Performance of High-Silica Concretes by Studying and

Characterizing Natural and Anthropogenic Analogs in order To Predict the Long-Term

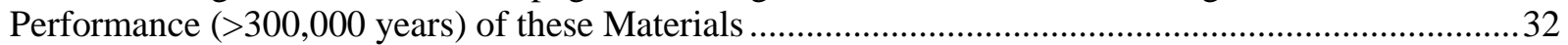

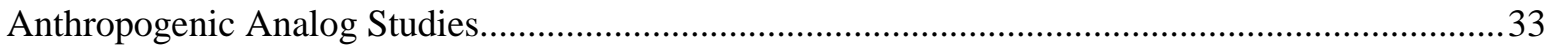

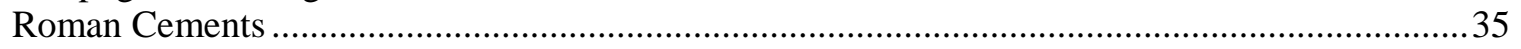

Natural Analogs ............................................................................................................... 36

Need 3: Negotiate and Coordinate Work Plans with Parallel Russian Program under an

International Science and Technology Center (ISTC) Agreement with the Russian Federation ............38

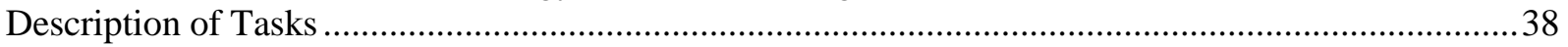

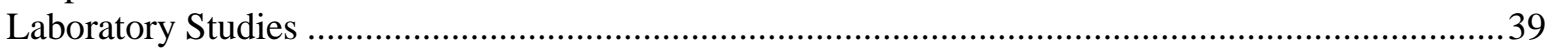

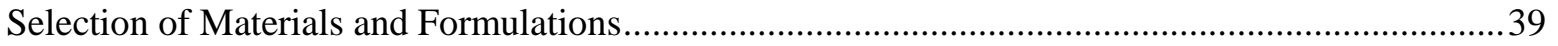

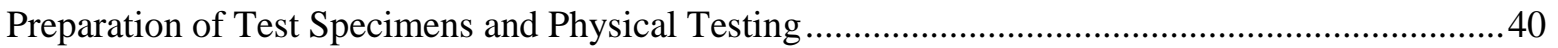

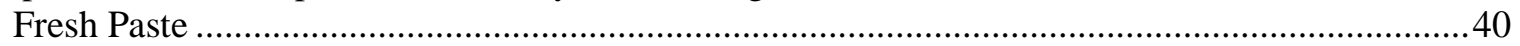

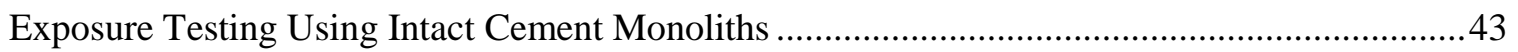

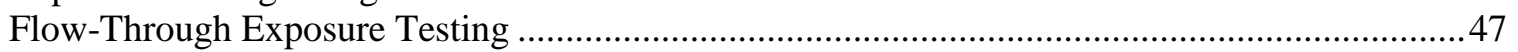

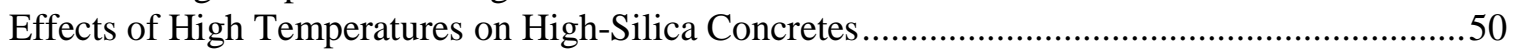

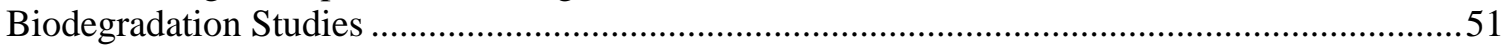

Chemical Analyses of Solid and Liquid Phases and Mineralogical Changes ..............................51 
Characterize and Detect the Phases that Form due to Interaction with Groundwater...................51

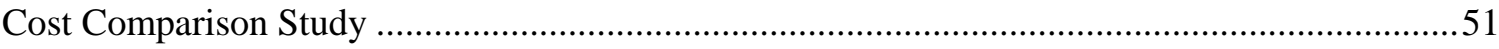

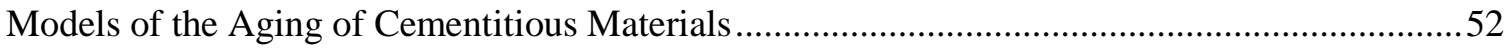

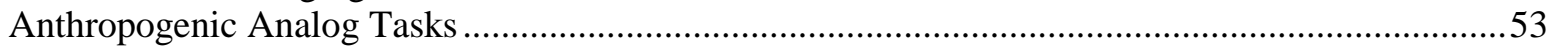

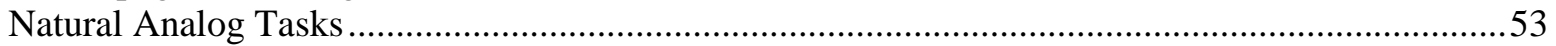

Laboratory Examination on Anthropogenic and Natural Samples ............................................54

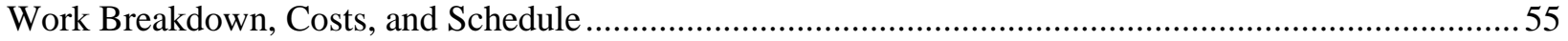

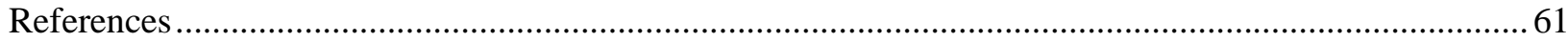

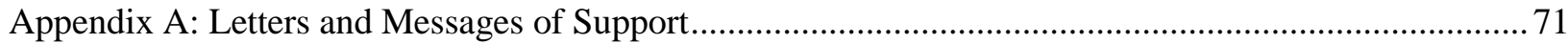

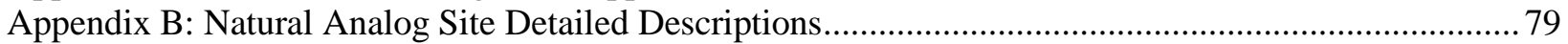

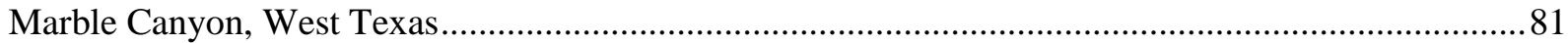

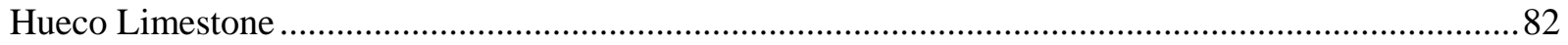

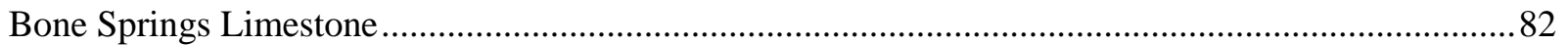

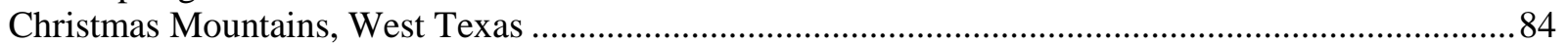

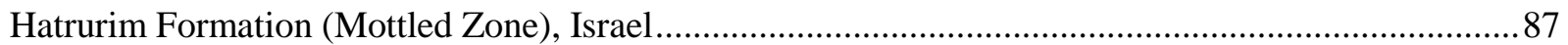

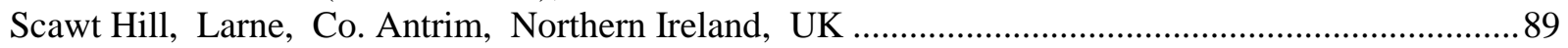

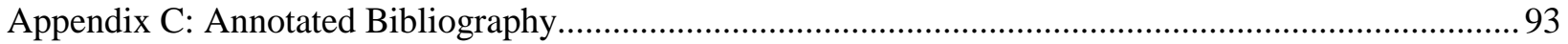




\section{LIST OF FIGURES}

Figure

1.

2.

3.

4.

5. Secondary mineral formation of the surface of the $\mathrm{UO}_{2}$ particles.

Blending selected slags, Class F fly ash, and other high-silica pozzolans with OPC

to form a composition that prevents the formation of a strong base calcium hydroxide

Portland cement with a pozzolanic additive suppresses the formation of free $\mathrm{Ca}(\mathrm{OH})_{2}$ and reduces hydroxide ion in solution, $\mathrm{OH}^{-}$, by the formation of insoluble and

soluble silica species.

Evolution of silicon concentration during the leaching of calcium silicate

hydrate $(\mathrm{CSH})$ gels - comparison of the leaching model with experimental results.

(a) Variation in $\mathrm{pH}$ during leaching of higher $\mathrm{Ca} / \mathrm{Si}$ ratio synthetic $\mathrm{CSH}$ gels in

demineralized water. (b) Variation in $\mathrm{pH}$ during leaching of lower $\mathrm{Ca} / \mathrm{Si}$ ratio synthetic

$\mathrm{CSH}$ gels in demineralized water.

Uranium fraction of the $\mathrm{U}$ leached from the basalt-sintered $\mathrm{UO}_{2}$ into DI-water,

$1 \mathrm{M} \mathrm{NaOH}$, and cement and OPC with blast furnace slag (BFS) porewaters

at 20,67 , and $150^{\circ} \mathrm{C}$ for up to 26 months..

7. Reaction sequence showing the alteration of precipitated uranyl phases observed

in drip tests with unirradiated $\mathrm{UO}_{2}$ and expected from observations on surficial weathering

zones on natural uraninite deposits.

8. With temperature, the solubility of $\mathrm{O}_{2}(\mathrm{~g})$ in groundwater influences the oxidative environment, along with $\mathrm{pH}$.

9. When saturated $\mathrm{O}_{2}$ (a) controls the groundwater Eh (based on Eq. 4), the conditions are always oxidizing (Eh $>0$ ) over the expected $\mathrm{pH}$ ranges of the buffered YM repository groundwater.

10. Activity-activity diagram for the system $\mathrm{SiO}_{2}-\mathrm{CaO}-\mathrm{UO}_{3}-\mathrm{H}_{2} \mathrm{O}$, constructed

excluding swanboite, uranosilite, haiweeite, and ursilite with the composition

typical groundwaters from crystalline rocks and for YM J-13.

11. Galvanic cells can form on the surface of metals through various mechanisms

associated with small inhomogeneities.

12. When the silica leached from the adjacent high-silica concrete structures, contacts the WP's metal surface, monomeric silica adsorbs onto metal surfaces at the anodic sites, forming a thin, insulating monomolecular film, preventing any further corrosive reaction at the anode.

13. (a) These plots show the pore size distributions in normal sand (quartz) filled cement mortars.

(b) Additions of blast furnace slag and silica fume (pozzolans) significantly

reduce the pore sizes in cement mortars.

14. Bound water contents of CSH gels.

15. Current YMP baseline underground tunnel build-out construction technology......................26

16. Examples of applications using high-silica concretes for the finish liners of YM disposal drifts and connecting tunnels. .28

17. For the YM repository, this illustrates the proposed application of a fiber-reinforced shotcrete tunnel lining with a high-strength concrete invert, both of which are fabricated using high-silica cements.

18. (a) Electron backscatter image of K-spar replacing albite at $600^{\circ} \mathrm{C}$. .......................................34

(b) ${ }^{18} \mathrm{O}$-enriched zones (light) coincident with K-Na exchange..................................................34

(c) NanoSIMS ion imaging (contour map on left; line scan on right) of

$\mathrm{O}$ isotopes in a reaction zone in which albite reacted with ${ }^{18} \mathrm{O}$-enriched

2 molal $\mathrm{KCl}$ at $600^{\circ} \mathrm{C}, 200 \mathrm{MPa}$ for 6 days. 



\section{LIST OF TABLES}

Table

1. Original concerns and current knowledge about the use of concretes in the

Page construction of YM Repository tunnels and drifts....

2. Values of $\mathrm{G}_{\mathrm{f}, 298}^{\circ}$ for the $\mathrm{U}(\mathrm{VI})$ minerals used in the construction of Fig. 10 .......................... 16

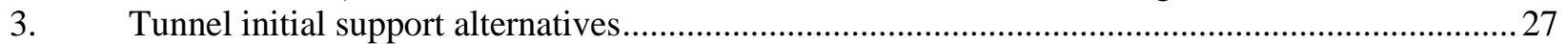

4. Final YM disposal drifts and connecting tunnels lining alternatives .......................................22

5. The composite YM solution to be used in this study compared with the J13

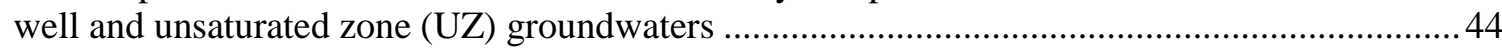





\section{ACROYNYMS}

$\begin{array}{ll}\text { ACI } & \text { American Concrete Institute } \\ \text { AMS } & \text { accelerator mass spectrometry } \\ \text { ASTM } & \text { American Society for Testing and Materials } \\ \text { BFS } & \text { blast furnace slag } \\ \text { CEA } & \text { Commissariat à l'Energie Atomique } \\ \text { CRWMS } & \text { Civilian Radioactive Waste Management System } \\ \text { CSH } & \text { calcium silicate hydrate } \\ \text { DIN } & \text { Deutsche Industrie Norm } \\ \text { EDX } & \text { electron dispersive X-ray } \\ \text { GFAA, } & \text { graphite furnace atomic adsorption } \\ \text { HECC } & \text { hydrogen electrode concentration cell } \\ \text { HRTEM } & \text { high-resolution transmission electron microscopy } \\ \text { IC } & \text { ion chromatography } \\ \text { ICP-AES } & \text { ion-coupled plasma emission spectra } \\ \text { ICP-MS } & \text { ion-coupled plasma mass spectra } \\ \text { ISTC } & \text { International Science and Technology Center } \\ \text { MGR } & \text { Monitored Geological Repository } \\ \text { MID } & \text { microbial influenced degradation } \\ \text { NRC } & \text { Nuclear Regulatory Commission } \\ \text { OCED/NEA } & \text { Organization for Economic Cooperation and Development/Nuclear Energy Agency } \\ \text { OPC } & \text { ordinary Portland cement } \\ \text { ORNL } & \text { Oak Ridge National Laboratory } \\ \text { ORP } & \text { oxidation-reduction potential } \\ \text { PTn } & \text { Paintbrush } \\ \text { RF } & \text { Russian Federation } \\ \text { SEM } & \text { scanning electron microscopy } \\ \text { SEMPA } & \text { scanning electron microscopy with polarization analysis } \\ \text { SIMS } & \text { secondary ion mass spectrometry } \\ \text { TEM } & \text { transmission electron microscopy } \\ \text { UZ } & \text { unsaturated zone } \\ \text { W/C } & \text { water-to-cement weight ratio } \\ \text { WP } & \text { waste package } \\ \text { YM } & \text { Yucca Mountain } \\ \text { YMP } & \text { Yucca Mountain Project } \\ & \end{array}$





\section{SUMMARY OF NEEDED RESEARCH}

\section{INTRODUCTION}

The current plans for the Yucca Mountain (YM) repository project (YMP) use steel structures to stabilize the disposal drifts and connecting tunnels that are collectively over 100 kilometers in length. The potential exist to reduce the underground construction cost by 100s of millions of dollars and improve the repository's performance. These economic and engineering goals can be achieved by using the appropriate cementitious materials to build out these tunnels. This report describes the required properties of YM compatible cements and reviews the literature that proves the efficacy of this approach. This report also describes a comprehensive program to develop and test materials for a suite of underground construction technologies.

\section{MEeting YMP NeEdS}

This project must develop and test high-silica cementitious materials for use in construction of Yucca Mountain inverts, drift liners, and bulkheads. The examinations of archaeological and geological samples show that high-silica cement binders are extremely durable. The cements, used by the Greeks and Romans, have survived for hundreds of years in hot water and for thousands of years in marine environments. Also, there are natural analogs with similar compositions that have persisted for millions of years. For the past century, high-silica cements have been widely used in civil engineering applications that require resistance and durability under extreme environmental stresses.

Through (1) these formulation studies, (2) the proposed testing protocols, (3) the study of anthropogenic and natural analogs, and (4) the applications of aging models, this study could present evidence to support a claim for liner performance that may reach up to 10,000 years or more.

In addition to having superior long-term durability to the steel support system, the application of highsilica cements to the build-out and lining of the YM repository connecting tunnels and disposal drifts results in potential cost savings of $\$ 112 \mathrm{M}$ or more in construction costs.

The formulations developed and tested in this study will be compatible with the following potential, initial YM tunnel support systems, which include the use of

- precast concrete segments,

- cast-in-place concrete, and

- $\quad$ shotcrete with or without rock bolts (and microreinforcement).

The selection of the preferred methods will depend on the actual ground conditions and the preference of the tunnel contractor, given their skill and experience with certain types of systems.

Both laboratory experiments and natural analog studies should be conducted to develop and test highsilica hydraulic, cementitious binders for use at YM. Personnel with the combination of expertise should conduct this work. The major tasks of this project are to (1) formulate and make candidate high-silica cementitious materials (e.g., pozzolans, trass, blast furnace slags), (2) measure their physical and chemical properties, (3) expose them [along with waste package (WP) materials] to static and flowing YM groundwater at expected repository temperatures, and (4) periodically examine specimens with nanoscale probes for chemical and mineralogical changes. 
These cementitious materials will be designed to buffer the $\mathrm{pH}$ and Eh of the groundwater, to slow corrosion of waste packages, and to retard migration of radionuclides. Compared to ordinary Portland cement (OPC), these materials, which are as strong and more durable, will be less expensive to produce (by as much as 30-50\%). As discussed in detail in the following sections, building the repository with cementitious materials will improve short- $(<2,000$ year) and long-term ( $>10,000$ year) repository performance.

As an additional benefit, high-silica binders suppress the formation of free calcium hydroxide in a OPC matrix that could leach and elevate the $\mathrm{pH}$ of any groundwater or brines with which it may come in contact.

By forming alteration minerals, this excess silica can also affect the capability of the cementitious structures to heal small micro-cracks caused by local tectonic stresses. A Canadian study verifies the results of Organization for Economic Cooperation and Development/Nuclear Energy Agency (OCED/NEA) in the Stripa mine in Sweden, confirming that the addition of silica fume reduced the hydraulic conductivity and increased the ability of the matrix to heal small fractures. Also, leachates from these cementitious binders are saturated in orthosilicates $\left(\mathrm{SiO}_{4} \mathrm{H}_{\mathrm{x}}{ }^{\mathrm{x}-4}\right)$ that are capable of passivating metal surfaces. These silicate minerals form very insoluble silicates of the actinides, fission products, and uranium, thereby significantly reducing the source-term mobility of radionuclides transported to the nearfield and far-field rocks by flowing groundwater.

Based on previous analyses (BCAA00000-01717-0200-00013 REV 00), the Yucca Mountain Project (YMP) has had reservations with regard to the use of Portland cement and concrete in the construction of the repository's underground drifts and tunnels. Current YMP documentation assumes that the chemistry of OPC and concrete will increase the 10,000-year dose-to-man by a hundred times. While inaccurate in the case of high-silica cements, some of YMP's conservative assumptions about the behavior and effects of high-silica concretes are summarized in Table 1.

The discussions that follow will show that the chemistry and physical properties of high-silica cements mitigate the concerns because of the current YMP assumptions. In addition, these proposed materials will substantially delay the release and reduce the mobility of uranium and the associated radionuclides. The experiments and analyses described in the following sections are expected to prove that high-silica cements are beneficial and cost-effective when used to construct the tunnel and drift build-out in the YMP Repository.

In the conditions expected in the YMP Repository, the ultimate objective of the project is to determine reaction mechanisms and kinetics of degradation and dissolution of this and other construction materials in order to predict their in-repository performance by thermodynamic and near-field transport modeling. Comparisons of the models with natural analogs will support the predicted long-term behavior of the proposed cementitious materials. 
Table 1. Original concerns and current knowledge about the use of concretes in the construction of YM Repository tunnels and drifts

\begin{tabular}{ll}
\multicolumn{1}{c}{ Assumptions/concern } & $\begin{array}{c}\text { Current knowledge about properties of } \\
\text { high-silica cements }\end{array}$ \\
\hline $\begin{array}{l}\text { 1. Concrete pore solutions with a high pH could } \\
\text { increase radionuclide solubility and mobility }\end{array}$ & $\begin{array}{l}\text { High-silica cements reduce the pH of } \\
\text { leachates that then react to form } \\
\text { insoluble uranium silicates }\end{array}$ \\
$\begin{array}{l}\text { 2. Water from dehydration of concretes increase the } \\
\text { relative humidity in tunnels and drifts }\end{array}$ & $\begin{array}{l}\text { The very fine closed-porosity and } \\
\text { capillary texture of high-silica cements } \\
\text { minimize moisture loss }\end{array}$ \\
$\begin{array}{l}\text { 3. The porosity, permeability, and transport } \\
\text { properties of the adjacent formation could be } \\
\text { changed to effect higher nuclide transport rates }\end{array}$ & $\begin{array}{l}\text { Silica-saturated leachates will reduce the } \\
\text { porosity and permeability in the adjacent } \\
\text { vitreous tuff }\end{array}$ \\
$\begin{array}{l}\text { 4. The superplasticizers in the concrete matrix could } \\
\text { form organic acids leading to the stabilization of } \\
\text { colloids, thereby increasing nuclide transport }\end{array}$ & $\begin{array}{l}\text { High-silica additives are water reducers } \\
\text { and lessen or eliminate the need for } \\
\text { organic surfactant additives }\end{array}$ \\
$\begin{array}{l}\text { 5.Organics and calcium sulfate in the concretes } \\
\text { could provide nutrients for microbiological } \\
\text { growth, accelerating corrosion of the waste } \\
\text { packages }\end{array}$ & $\begin{array}{l}\text { Microorganisms cannot extract nutrients } \\
\text { from impermeable, high-silica cements }\end{array}$ \\
$\begin{array}{l}\text { 6.Little can be done to show that engineered } \\
\text { materials are durable in the time scales (10,000 to } \\
\text { 1,000,000 years) of the YMP risk assessments }\end{array}$ & $\begin{array}{l}\text { High-silica grouts and cements have } \\
\text { existed for 6,000 years, and natural } \\
\text { analogs have weathered for 10s of } \\
\text { millions of years }\end{array}$ \\
\hline
\end{tabular}

\section{ReCommended EXPerimental Studies AND ANALySeS}

This array of experiments and analytical tools must be used to determine the primary mechanisms and rates of elemental releases to the YM groundwater during the alteration and corrosion of the candidate cementitious construction and waste package materials. Also, modeling in conjunction with analog studies permits extrapolation of the performance of the selected high-silica binders into the time frames necessary to show improvements in the YMP risks to the environment and human health.

- Anthropogenic samples can be collected with the cooperation of museums and archeologists from Europe and Asia.

- Natural samples can be collected both by field trips and by cooperation with geologists from the United States, Europe, and Asia.

- Archeological and natural samples should be examined and compared to the samples exposed during the laboratory studies.

- Laboratory and natural analog data should be compared with the prediction of current, selected models of the aging of cementitious materials. 
The laboratory studies should include:

1. Static and flow-through (dynamic) tests lasting up to 3 years will study interactions of candidate cementitious materials and WP materials with YM groundwater at $30-160^{\circ} \mathrm{C}$.

2. During these tests, the chemistry of the solid and liquid phases and the mineralogical changes in the cement should be measured to determine the extent of mineral alterations and formation of corrosion products.

3. GFAA, ICP-MS, ICP-AES, and IC are the principal tools for monitoring the composition and $\mathrm{pH}$ of the groundwater. However, the extent of dissolution of the cements is expected to be very small and below the limit of detection of normal analytical methods. Therefore, measuring the concentration of cement constituents in water may require analysis by radiochemical means. For example, ${ }^{90} \mathrm{Sr}$ could substitute for a small part of the calcium content.

4. Petrographic and scanning electron microscopy (SEM), along with scanning electron microscopy with polarization analysis (SEMPA), high-resolution transmission electron microscopy (HRTEM) techniques, and transmission electron microscopy (TEM) imaging can be used to characterize and detect the phases that form due to interaction with groundwater.

5. Isotopically labeled water will allow isotopic and elemental imaging using secondary ion mass spectrometry (SIMS) to track the migration of the fluid into the solid samples at the micro- and nanoscale.

6. Cost comparison study of current practices that use concretes in the build-out of underground tunnels and drifts with the current YMP underground construction baseline should evaluate potential reductions in costs.

7. Comparisons of laboratory and natural analog data will be compared with the predicted characteristics of current selected models of the aging of cementitious materials to allow the extrapolation of measured performances and the long-term source terms in order to be included in the YMP risk models.

\section{Natural Analog Studies}

Extrapolation of laboratory data to longer periods used in performance assessment calculations is a challenge. Spent fuel is required to remain isolated for more than 10,000 years. Natural analogs must be used to provide evidence of this type of longevity. Such analogs have been used extensively to evaluate the long-term performance of radioactive waste repositories at realistic time scales and geological conditions. Natural laboratories exist in which to study the environmental effects on materials over very large spatial and temporal scales.

To assess the long-term stability of the candidate cementitious materials, researchers should characterize the effects of weathering and alteration of natural and man-made analogs of the cementitious matrices proposed for YM. This effort should first examine ancient Roman pozzolans, then million-year-old natural samples from sanidinite-facies metamorphic rocks in Marble Canyon, Texas, and the Hatrurim formation in Israel. These formations contain many of the same phases that form in high-silica cements. For example, the minerals hatrurite, larnite, and their polymorphs exist in these rocks and are natural analogs for the common cement-clinker phases "alite" $\left(\mathrm{Ca}_{3} \mathrm{SiO}_{5}\right)$ and "belite" $\left(\mathrm{Ca}_{2} \mathrm{SiO}_{4}\right)$. These cementitious analogs and their alteration products provide the opportunity to study transport processes and durabilities on geologic time scales. 


\section{RESPONSIBILITIES}

Experienced laboratories must be used to formulate, prepare, and distribute the experimental cements; perform the physical testing, petrography, HRTEM, SEMPA, SIMS, SEM, TEM, GFAA, ICP-AES, IC, and ICP-MS analyses; and conduct the static exposure experiments. They should also perform the flowthrough tests and lead the modeling and the natural analog studies. This work should be coordinated with the Russian Minatom program at Sarov for the study of similar materials and exchange samples and information with the U.S. program.

\section{INTRODUCTION}

Construction plans for the Yucca Mountain (YM) Repository do not currently call for significant use of cements or concretes despite the obvious advantages of these materials for construction purposes. This is due to several concerns about the long-term effects and stability of cements in the repository environment described throughout Yucca Mountain Project (YMP) documentation and summarized in Table 1. For example, Sections 6.2.1- 6.2.2 of the Evaluation of Alternative Materials for Emplacement Drift Ground Control (BCAA00000-01717-0200-00013 REV 00) and Table 6-1 report the results of transport analysis, which suggested that cements would accelerate the rate of release and increase the mobility of uranium, fission products, and actinides. Based on evidence as to how groundwaters modified by standard ordinary Portland cement (OPC) form and behave, this model indicates that the presence of OPCs will increase the mobility of radionuclides.

While the specific chemical reactions leading to these results are based on experimental data that have been extrapolated to anticipated YM conditions, these severe consequences can be avoided. Significant advantages can be realized under the conditions in the YM repository by using high-silica cements rather than OPC. The addition of reactive silica to OPC significantly modifies its chemistry. Therefore, the use of high-silica cements would allow the construction and cost-saving advantages of cements to be obtained in the repository without the apparent disadvantages. This report addresses the six major assumptions used in the YMP analysis of the use of OPC and demonstrates that the use of high-silica cements results in practical advantages.

High-silica binders have a number of advantages for YM applications. The examinations of archaeological and geological samples show that high-silica cement binders are extremely durable. These cements, used by the Greeks and Romans, have survived for hundreds of years in hot water and for thousands of years in marine environments. As an additional benefit, high-silica binders are as strong as OPC, but suppress the formation of free calcium hydroxide that elevates the $\mathrm{pH}$ in OPC. High-silica binders also cost 30-50\% less. Furthermore, stoichiometric-excess silica in these binders seals stress cracks in structures by forming alteration minerals and leachates from these cementitious binders are nearly saturated in orthosilicates $\left[\mathrm{SiO}_{4} \mathrm{H}_{\mathrm{x}}{ }^{\mathrm{x}-4}\right]$, which passivate metal surfaces. In addition, silicate minerals are also very strong radionuclide absorbers. Reactions between free actinides, fission products, or uranium with silica in the cement, its alteration products, or its leachates result in the formation of very insoluble silicates. Therefore, it is expected to be demonstrated that, by increasing the glassy-silica (pozzolanic) content of the concretes conditions can be prevented under which mobilizing reactions occur. This formulation will also significantly delay the release and retard the mobility of uranium, fission products, and actinides by factors of 100 to 10,000 .

One of the most challenging aspects of nuclear waste management is the extrapolation of laboratory data, collected over short periods of time (hours to years) to longer periods used in performance assessment calculations (e.g., Finch and Ewing, 1992; Janeczek et al., 1996). Most geologic disposal concepts require that the spent fuel remain isolated from the accessible environment for more than 10,000 years (i.e., the time required for the fission and actinide products to decay to safe levels), and recent court decisions may 
require isolation at YM to exceed 300,000 years. Extrapolation of laboratory data can lead to significant uncertainty that can potentially impact public acceptance of the findings.

For this reason, natural analogs for predicting the fate of various components of the Yucca Mountain repository have been used extensively to evaluate the long-term performance of radioactive waste repositories under realistic time scales and geological conditions. The environments that host these natural analogs are ideal natural laboratories in which to study the environmental effects on materials over very large spatial (nanometers to kilometers) and temporal scales (thousands to millions of years).

\section{SCIENTIFIC BASIS FOR USING HIGH-SILICA CEMENTS}

\section{Yucca Mountain Project Concerns with the Uses of Cements in the YM REPOSITORY}

Based on several concerns described throughout the YMP document on the Evaluation of Alternative Materials for Emplacement Drift Ground Control (BCAA00000-01717-0200-00013 REV 00), the wide use of cements is currently not included in the YM repository construction plans.

Currently the YMP assumes that (1) cements accelerate the release and increase the mobility of uranium, fission products, and actinides and (2) specific selected mechanisms apply to the formation and behavior of uranium and radionuclides in concrete-modified groundwater. These assumptions resulted in the prediction of a dose rate increase of a 100-fold for the 10,000-year peak dose to the average member of the critical group. The specific chemical reactions supporting these assumptions are based on previous experience in processing uranium ore, which are then extrapolated to the geochemical conditions of the YM site. These assumptions, however, are based on the free calcium hydroxide found in OPC-cements, and do not consider the beneficial reactions that would occur in the presence of high-silica cements. With high-silica cements, the waste package (WP), uranium, and groundwater interactions actually retard the release and migration of radioactivity from the repository.

In particular, increasing the glassy-silica (pozzolanic) content of the concretes can prevent reactions leading to dissolution and transport of nuclides. With high-silica materials, the concrete-modified YM groundwater can significantly delay the release and retard the mobility of uranium, fission products, and actinides by factors of 1/100 to 1/10,000 (Mattus, Dole 2003).

\section{Summary of Concerns}

The principal concerns with the use of OPC in YMP are

1. Leachates from concrete with a high $\mathrm{pH}(>10)$ in contact with $\mathrm{UO}_{2}$ could increase radionuclide solubility and mobility.

2. Water from the dehydration of concretes could increase the relative humidity in the tunnels and drifts.

3. Leachates dissolving the adjacent vitreous tuff could increase the porosity, permeability, and transport properties of the adjacent formation and could result in higher water-borne transport rates of nuclides.

4. Superplasticizers in the concrete matrix could form organic acids that stabilize colloids, thereby increasing radionuclide transport from the repository.

5. The organics and calcium sulfate hydrate (gypsum) could provide a substrate for microbiological growth that would accelerate corrosion of the waste package and increase the availability of radionuclides for transport to near and far field.

6. Little can be done to show that engineered materials are durable in the time scales $(10,000$ to $1,000,000$ years) of the YMP risk assessments. 
The discussions that follow will show that these assumptions do not apply to the chemistry and physical properties of high-silica cements. To the contrary, these proposed materials will substantially reduce the time of release and will reduce the mobility of uranium and the associated radionuclides. The experiments and analyses described in the following sections are expected to prove that high-silica cements will be beneficial and cost effective for construction of the tunnel and drift build-out in the YM repository.

\section{Addressing YMP Concerns}

The following discussions respond to concerns about using cements and provide support for the use of pozzolan-modified OPC in the build-out of the YM tunnels and disposal drifts.

\section{Silicates Suppress the Formation of Calcium Hydroxide}

One of the most important YMP concerns is that YM groundwater that comes in contact with concrete will have a very high $\mathrm{pH}(>10)$ from leaching the Portlandite ${ }^{\mathrm{a}}$. Then, this high $\mathrm{pH}$ will increase the mobility of uranium and other radionuclides. During the setting of cement pastes, the calcined minerals that make up OPC powder react with water to form in calcium hydroxide $\left(\mathrm{Ca}(\mathrm{OH})_{2}\right.$, Portlandite, $\left.\mathrm{CH}^{\mathrm{b}}\right)$ as a by-product of solidification. For water and tricalcium silicate $\left(\mathrm{C} 3 \mathrm{~S}^{\mathrm{b}}\right)$, Equation 1 gives an example of the spontaneous reaction at $35^{\circ} \mathrm{C}$ with a negative Gibbs energy $\left(\mathrm{G}_{35^{\circ} \mathrm{C}}=32 \mathrm{kcal} / \mathrm{mol}\right)$ and a large release of heat $\left(\mathrm{H}_{35^{\circ} \mathrm{C}}=-51 \mathrm{kcal} / \mathrm{mol}\right)$.

$$
\begin{aligned}
2(\mathrm{CaO})_{3} \mathrm{SiO}_{2}+7 \mathrm{H}_{2} \mathrm{O}(\mathrm{l}) & =5 \mathrm{Ca}(\mathrm{OH})_{2}+\mathrm{CaO}\left(\mathrm{SiO}_{2}\right)_{2} * 2 \mathrm{H}_{2} \mathrm{O} \\
\mathrm{G}_{35^{\circ} \mathrm{C}} & =-32 \mathrm{kcal} / \mathrm{mol}
\end{aligned}
$$

The hexagonal crystals of Portlandite $\left(\mathrm{Ca}(\mathrm{OH})_{2}\right)$ are the most soluble, leachable phase that is embedded in the cured OPC matrix. If there were no additional buffering of the $\mathrm{pH}$ by a solution saturated in silicates, the hydroxyl ion, $\mathrm{OH}^{-}$, concentrations could rise to above $1 \times 10^{-4} \mathrm{~mol} / \mathrm{L}(\mathrm{pH}>10)$. In the presence of this high $\mathrm{pH}$ and groundwater carbonate anions, $\mathrm{CO}_{3}{ }^{-2}$, formation of very soluble, mobile uranyl carbonate species, such as $\mathrm{UO}_{2}\left(\mathrm{CO}_{3}\right)_{2}{ }^{-2}$ and $\mathrm{UO}_{2}\left(\mathrm{CO}_{3}\right)_{3}{ }^{-4}$ (Langmuir 1978) do occur. However, this situation does not occur if the groundwater-leachate or cement porewaters are saturated in silicates and aluminates and are consequently buffered.

In the case of high-silica pozzolanic cement formulations, calcium hydroxide is consumed by reaction with glassy silica $\left(\mathrm{SiO}_{2}(\mathrm{G})\right)$.

$$
\begin{gathered}
\mathrm{Ca}(\mathrm{OH})_{2}+2 \mathrm{SiO}_{2}(\mathrm{G})+\mathrm{H}_{2} \mathrm{O}=\mathrm{CaO} * 2 \mathrm{SiO}_{2} * 2 \mathrm{H}_{2} \mathrm{O} \\
\mathrm{G}_{35^{\circ} \mathrm{C}}=-9 \mathrm{kcal} / \mathrm{mol}
\end{gathered}
$$

The candidate cements proposed for YM will have a stoichiometric excess of glassy silica to minimize the formation of calcium hydroxide. The extent of silica addition is limited by the mechanical strength and setting requirements of the specific concrete application.

An example of the effect of silica on cement pastes is shown in Fig. 1 (Hoyle 1988; Roy, Scheetz 1992) that shows the stability field of compositions of $\mathrm{SiO}_{2}-\mathrm{CaO}+\mathrm{MgO}-\mathrm{Al}_{2} \mathrm{O}_{3}$ in which calcium hydroxide is not stable. By blending OPC with high-silica additives, the composition can be moved into a composition field in which the free hydroxide cannot form.

a Portlandite is also known as calcium hydroxide $\left(\mathrm{Ca}(\mathrm{OH})_{2}\right)$ and "slaked" lime.

b Cement clinker phases are described in a confusing cement chemist's shorthand where: $\mathrm{C}=\mathrm{CaO}, \mathrm{S}=\mathrm{SiO}_{2}, \mathrm{H}=$ $\mathrm{H}_{2} \mathrm{O}, \mathrm{A}=\mathrm{Al}_{2} \mathrm{O}_{3}, \mathrm{~F}=\mathrm{Fe}_{2} \mathrm{O}_{3}$, and $\hat{\mathrm{S}}=\mathrm{SO}_{3}$ 


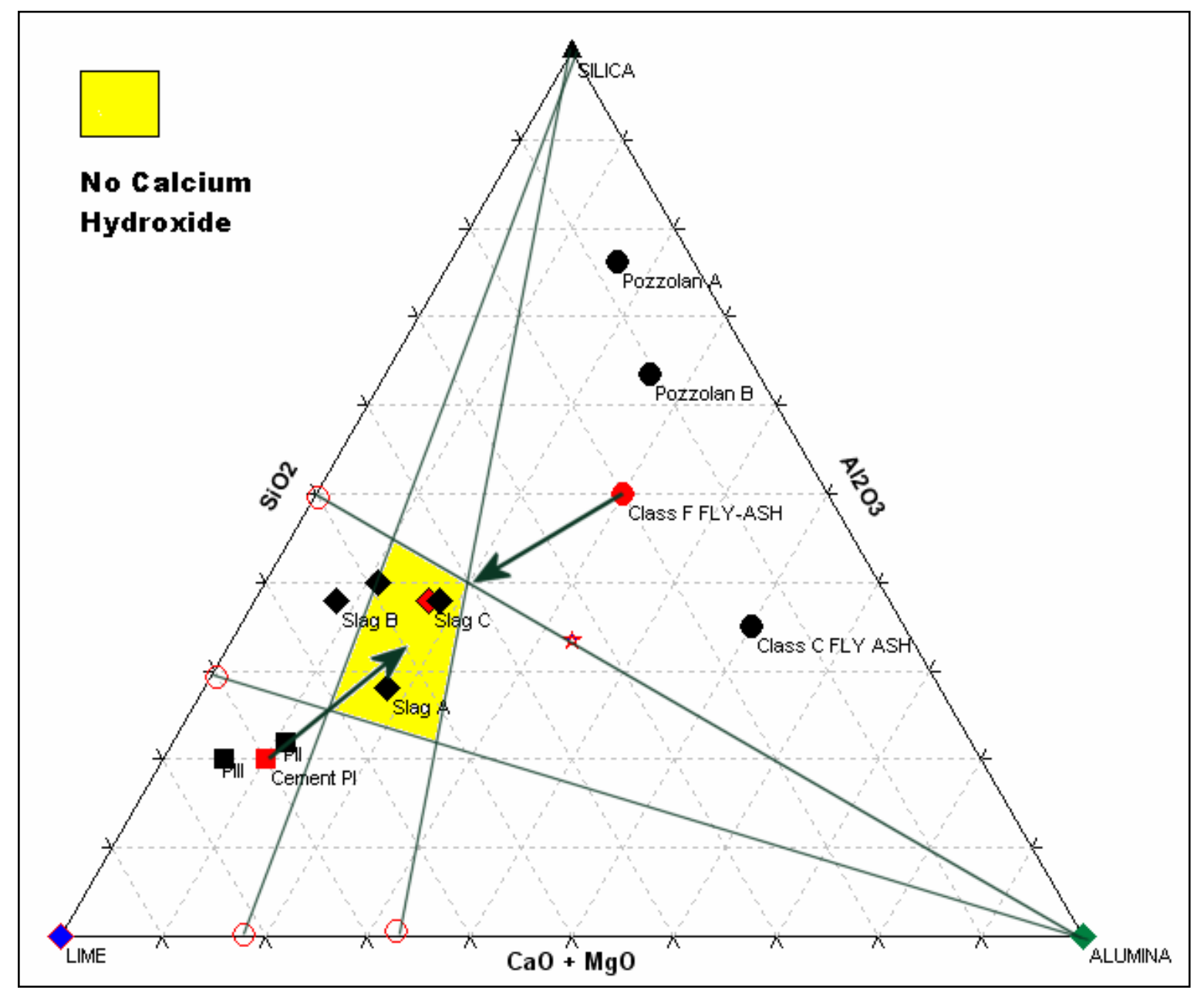

Fig. 1. Blending selected slags, Class $\mathrm{F}$ fly ash, and other high-silica pozzolans with OPC to form a composition that prevents the formation of a strong base calcium hydroxide (Roy, Scheetz 1992). The potential sources of fine glassy silica are American Society for Testing and Materials (ASTM) Class F fly ashes (ASTM C 618-99), blast furnace slags (Daube, Bakker 1986), silica fume (Malhota et al. 1987, Hooton 1986), volcanic pumice $^{a}$, and other high-silica glassy powders (Glasser et al. 1987).

High-silica contents of blended cements develop finer pore structures and give the final concrete matrices enhanced chemical resistances (Hooton 1986, Malhota et al. 1987, Gaal et al. 2003). Also, these highsilica binders can seal small stress cracks in structures by forming alteration-minerals that close microcracks caused by localized stresses. A Canadian study verified the results of the OCED/NEA in the Stripa Mine in Sweden, confirming that the addition of silica fume reduced the hydraulic conductivity and increased the matrix's ability to heal small fractures (Onofrei et al. 1989).

There are extensive monographs and international proceedings on the beneficial results of adding pozzolans to cements in order to lower their permeability and increase their durability (Calleja 1980; Ramachandran 1984; Daube, Bakker 1986; Roberts 1989; ACI SP-114 1989; Malhota 1989; Spence 1993; Calleja 1997; ACI 233R-03 2004).

\footnotetext{
a A glassy volcanic rock, usually of dacite or rhyolite composition; it is formed by the expansion of gas in erupting lava. Commonly seen as lumps or fragments of pea-size and larger; also occurs as ash-size particles.
} 
At equilibrium, high-silica cement systems are dominated by silicates, such as $\mathrm{Si}(\mathrm{OH})_{3}{ }_{3}, \mathrm{H}_{4} \mathrm{SiO}_{4}, \mathrm{H}_{2} \mathrm{SiO}_{3}$, and $\mathrm{SiO}_{2}(\mathrm{G})$. These silicate species can react with actinides, fission products, and uranium to form very insoluble silicate compounds. This can significantly reduce the concentrations of radionuclides transported by flowing groundwater from the YM waste disposal horizon to the near-field and far-field rocks. Figure 2 presents equilibrium compositional calculations of some of the predominant compounds and solution species as the temperature of the OPC-silica-water system is raised to the boiling point of water. These calculations were performed using Outokumpu HSC V5.11 software and thermodynamic database.

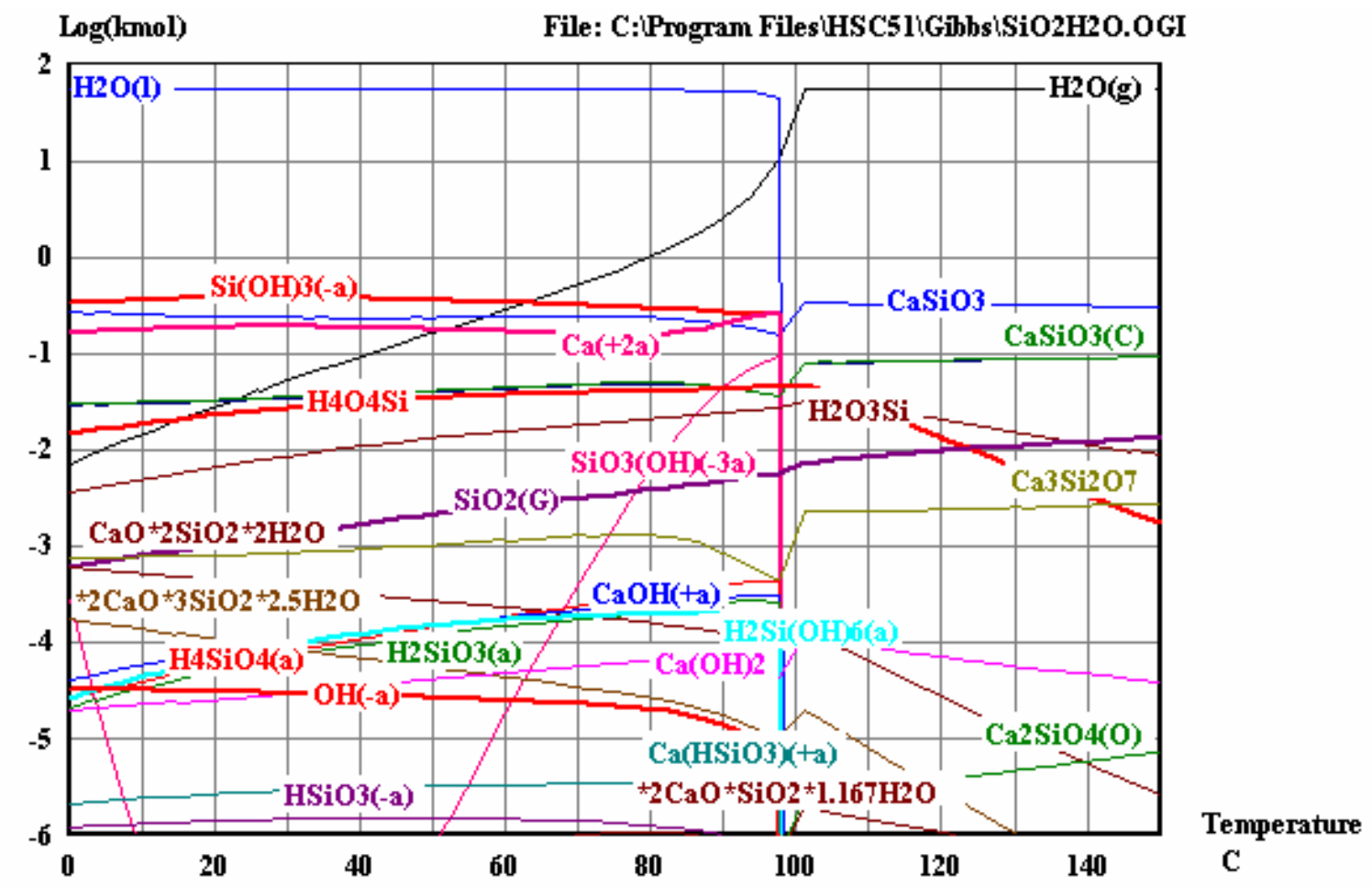

Fig. 2. Portland cement with a pozzolanic additive suppresses the formation of free $\mathrm{Ca}(\mathrm{OH})_{2}$ and reduces hydroxide ion in solution, $\mathrm{OH}^{-}$, by the formation of insoluble and soluble silica species. (Outokumpu Research Oy HCS V5.1 code and database created this graph).

At equilibrium with a stoichiometric excess of glassy silica, $\mathrm{SiO}_{2}(\mathrm{G})$, the cement porewater and leachates are saturated in silica to a range of $10^{-3}$ to $10^{-2} \mathrm{~mol} / \mathrm{L}$. Aerobic conditions at a $\mathrm{pH}<10$ promote the formation of very insoluble uranium oxides and silicates (Langmuir 1978). Uranyl silicates readily form in the presence of soluble silicates at temperatures of $80-150^{\circ} \mathrm{C}$ (Oji 2004). Compared to the adjacent YM groundwater in the adjacent unsaturated zone (UZ) and in the J13 groundwater with silica concentrations that range from $4.8 \times 10^{-4}$ to $6.5 \times 10^{-4} \mathrm{~mol} / \mathrm{L}$ (Rosenberg et al. 2001), insoluble silicates are more likely to be formed in the presence of high-silica cement leachates. Therefore, nuclides will be less mobile.

Evidence is clear that increasing the silica content of concrete formulas will result in higher silica concentration in the leachates, as is shown by Harris et al. (2002) in Fig 3. 


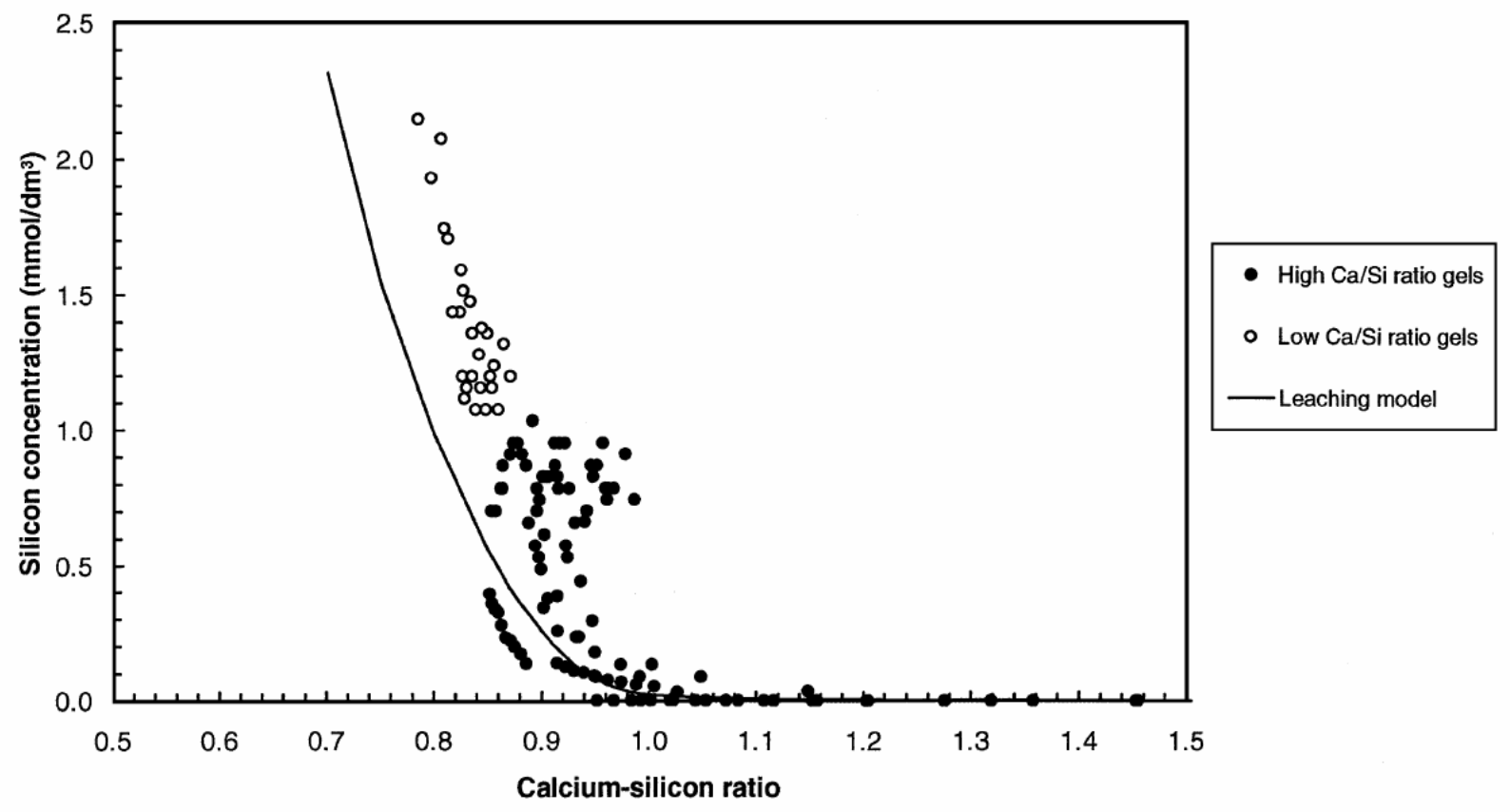

Fig. 3. Evolution of silicon concentration during the leaching of calcium silicate hydrate (CSH) gelscomparison of the leaching model with experimental results (Harris et al. 2002).

The increased silica concentrations in the cement porewater and adjacent leachates also moderate the $\mathrm{pH}$, as shown in Fig. 4. The variation in $\mathrm{pH}$ with the degree of leaching by demineralized water is shown in Fig. 4 (a) and Fig. 4 (b) for the higher and lower $\mathrm{Ca} / \mathrm{Si}$ ratio gels, respectively. These results demonstrate that the initial stages of the dissolution of a range of $\mathrm{CaO} \bullet \mathrm{SiO}_{2} \bullet \mathrm{H}_{2} \mathrm{O}$ [calcium silicate hydrate (CSH)] gels into dematerialized water are not incongruent, and are then followed by an approach to congruent behavior (Harris et al. 2002). This sequential leaching of CSH gels apparently results in a lower solubility for the congruently dissolving composition than is predicted from static dissolution.

As a recent experimental example of $\mathrm{UO}_{2}$ interaction with cement and silica under mild hydrothermal conditions, leaching tests on $\mathrm{UO}_{2}$ sintered with basalt that were exposed to cement porewater for over 6 months at temperatures of $25-150^{\circ} \mathrm{C}$ showed $1 / 100$ to $1 / 10,000$ uranium solubility (Mattus, Dole 2003). Figure 5 shows the secondary mineral formation of the surface of the $\mathrm{UO}_{2}$ particles resulting from the reactions between the cement porewater and the silicate-basalt sintering agent (Mattus, Dole 2003).

In Fig. 5, panel 5A shows the clean, etched surface of the basalt-sintered $\mathrm{UO}_{2}$ particles. Panel 5B shows the mineralization on the $\mathrm{UO}_{2}$ surface of etched basalt components in $1 \mathrm{M} \mathrm{NaOH}$. Panels $5 \mathrm{C}$ and $5 \mathrm{D}$ show the occlusion of the $\mathrm{UO}_{2}$ particle surfaces with a calcium aluminosilicate layer that forms from the cement porewater constituents and the leached silicates from the basalt sintering agent.

Similar to effects of glassy pozzolanic additives, this coating suppresses uranium's solubility and availability for transport, as well as the other radionuclides contained within the $\mathrm{UO}_{2}$ matrix. Also, this coating slows the dissolution of the cement's aluminosilicate matrix (Faucon et al. 1998). In another significant example, a Canadian study verifies the results of OCED/NEA in Stripa Mine, confirming that chemical changes as a result of the interactions with groundwater cause the formation of secondary alteration phases that repress the leaching processes (Onofrei, Gray 1989). 
(a)

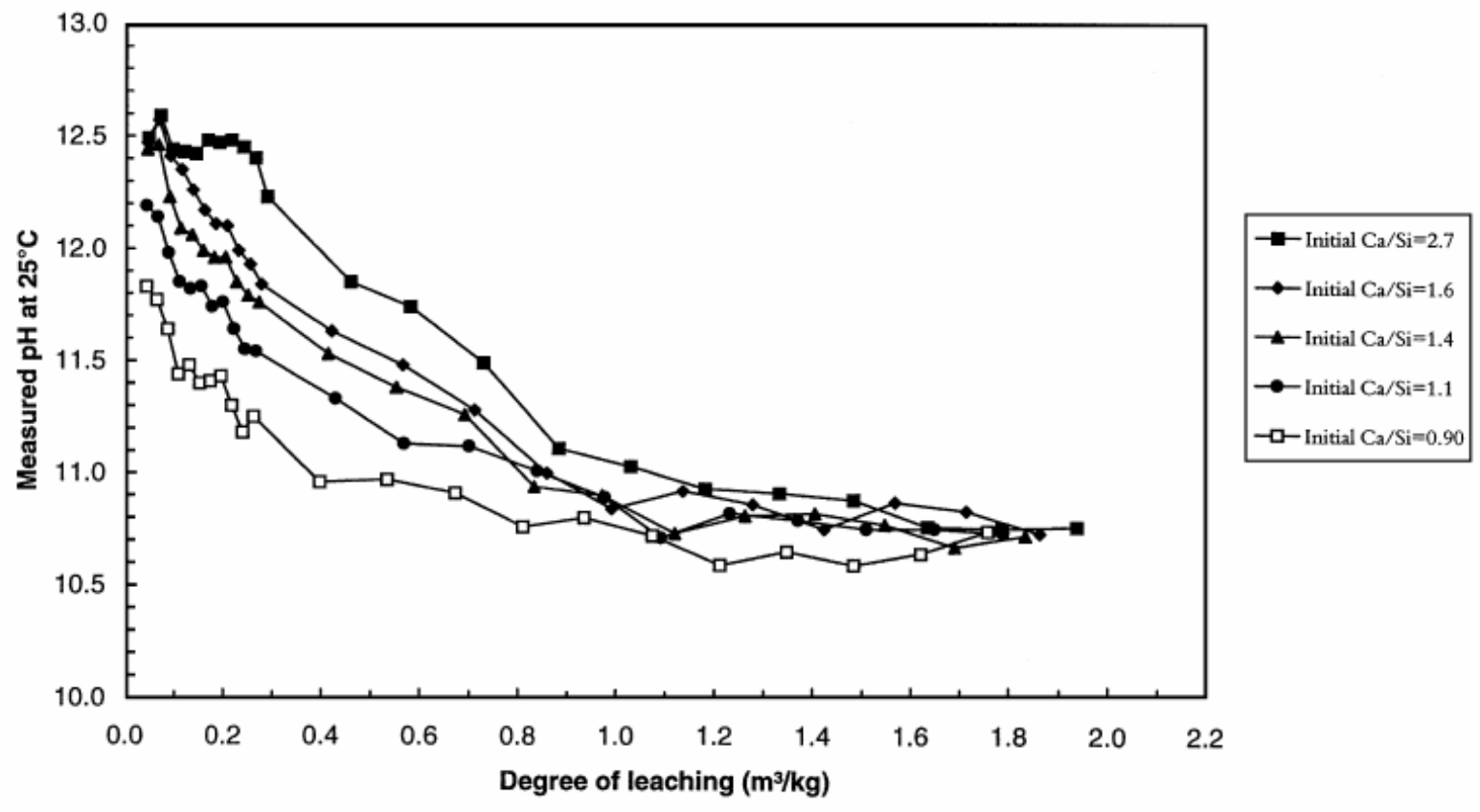

(b)

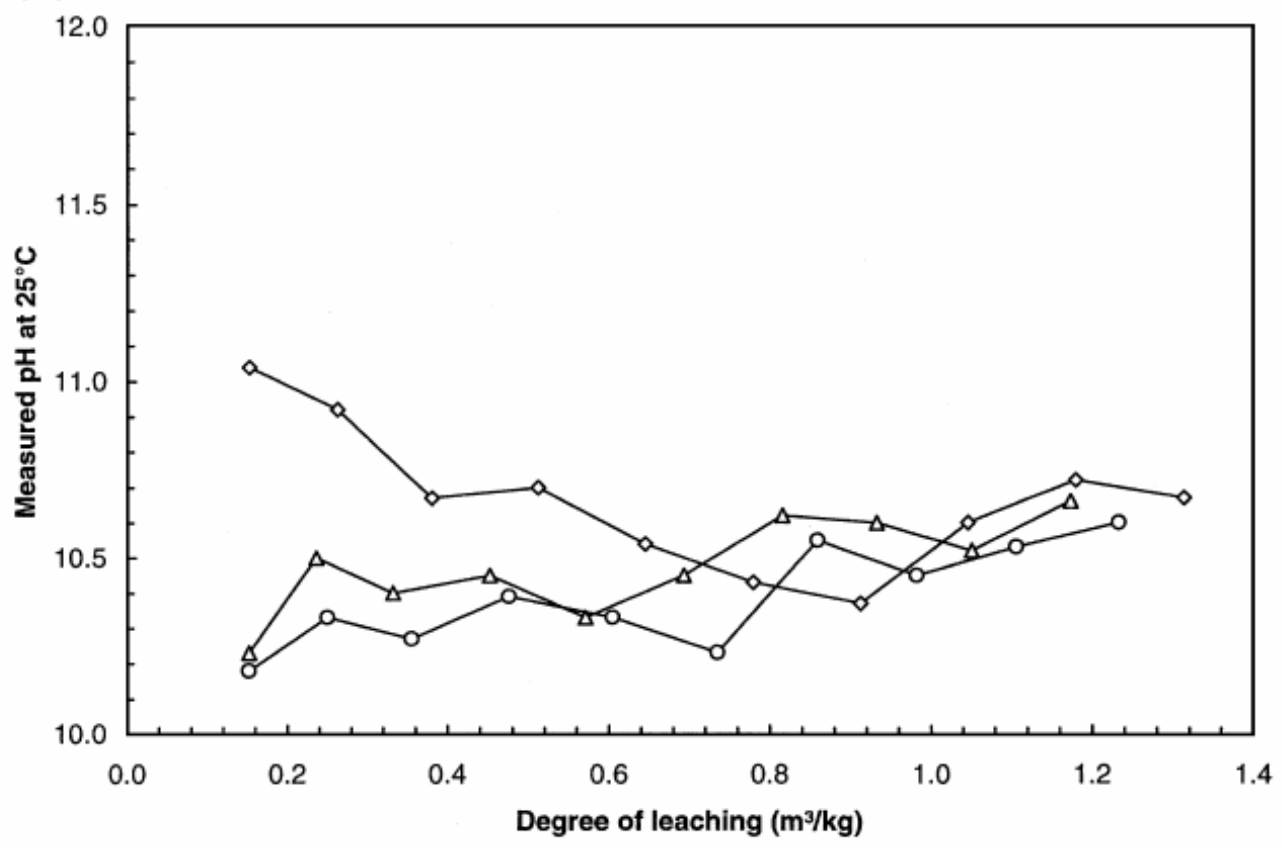

$\leadsto$ Initial $\mathrm{Ca}_{2} / \mathrm{Si}=0.81$ $\triangle-$ Initial $\mathrm{Ca} / \mathrm{Si}=0.76$ -0 - Initial $\mathrm{Ca} / \mathrm{Si}=0.72$

Fig. 4. (a) Variation in $\mathrm{pH}$ during leaching of higher $\mathrm{Ca} / \mathrm{Si}$ ratio synthetic $\mathrm{CSH}$ gels in demineralized water. (b) Variation in pH during leaching of lower $\mathrm{Ca} / \mathrm{Si}$ ratio synthetic CSH gels in demineralized water (Harris et al. 2002). 


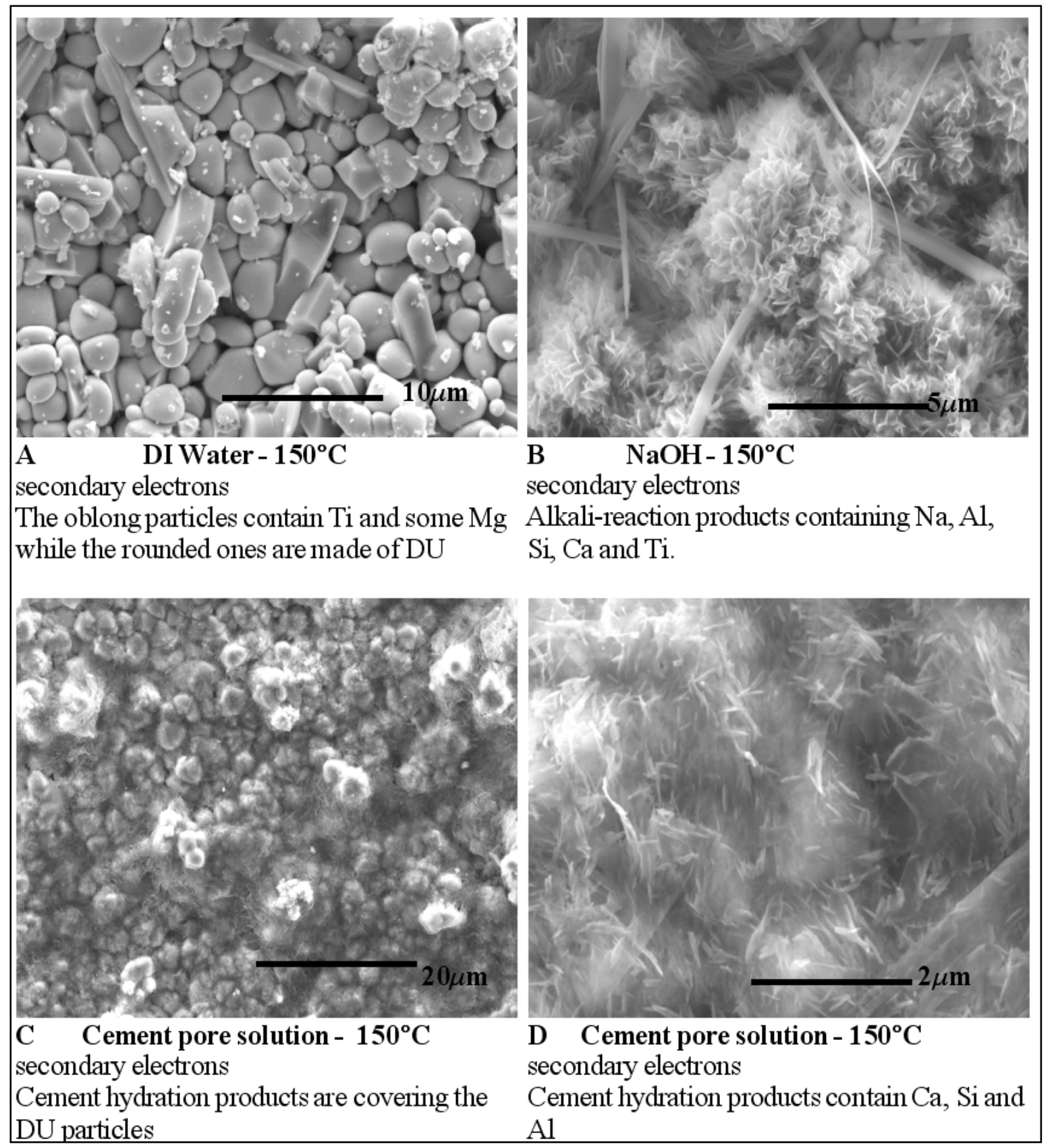

Fig. 5. Secondary mineral formation of the surface of the $\mathbf{U O}_{2}$ particles. Panel A shows the clean, etched surface of the basalt-sintered $\mathrm{UO}_{2}$ particles. Panel B shows the mineralization on the $\mathrm{UO}_{2}$ surface of etched basalt components in $1 \mathrm{M} \mathrm{NaOH}$. Panels $\mathrm{C}$ and $\mathrm{D}$ show the dense covering and occlusion of the $\mathrm{UO}_{2}$ particle surfaces with dense calcium aluminosilicates that form from the cement porewater and the silicates in the basalt sintering agent. Source: Mattus, C. H. and L. R. Dole. 2003. "Durability of Depleted Uranium Aggregates (DUAGG) in DUCRETE Shielding Applications," International High-Level Radioactive Waste Management Conference, Las Vegas, NV, USA, American Nuclear Society, La Grange Park, IL USA, 03/30/2003-04/02/2003. 
Figure 6 shows the associated uranium leaching data from the case in Fig. 5. Figure 6 compares the relative leaching between OPC and blast-furnace slag (BFS) altered-cement porewaters at 20,67, and $150^{\circ} \mathrm{C}$ for up to 13 months (Mattus, Dole 2003). The pattern of the slight rise and fall of the percentage of $\mathrm{U}$ leached in the $1 \mathrm{M} \mathrm{NaOH}$ and the cement porewater reflects the formation and scavenger precipitation of insoluble silicates in conjunction with the dense hydroaluminosilicate phases that form on the $\mathrm{UO}_{2}$ surfaces (Fig. 5).

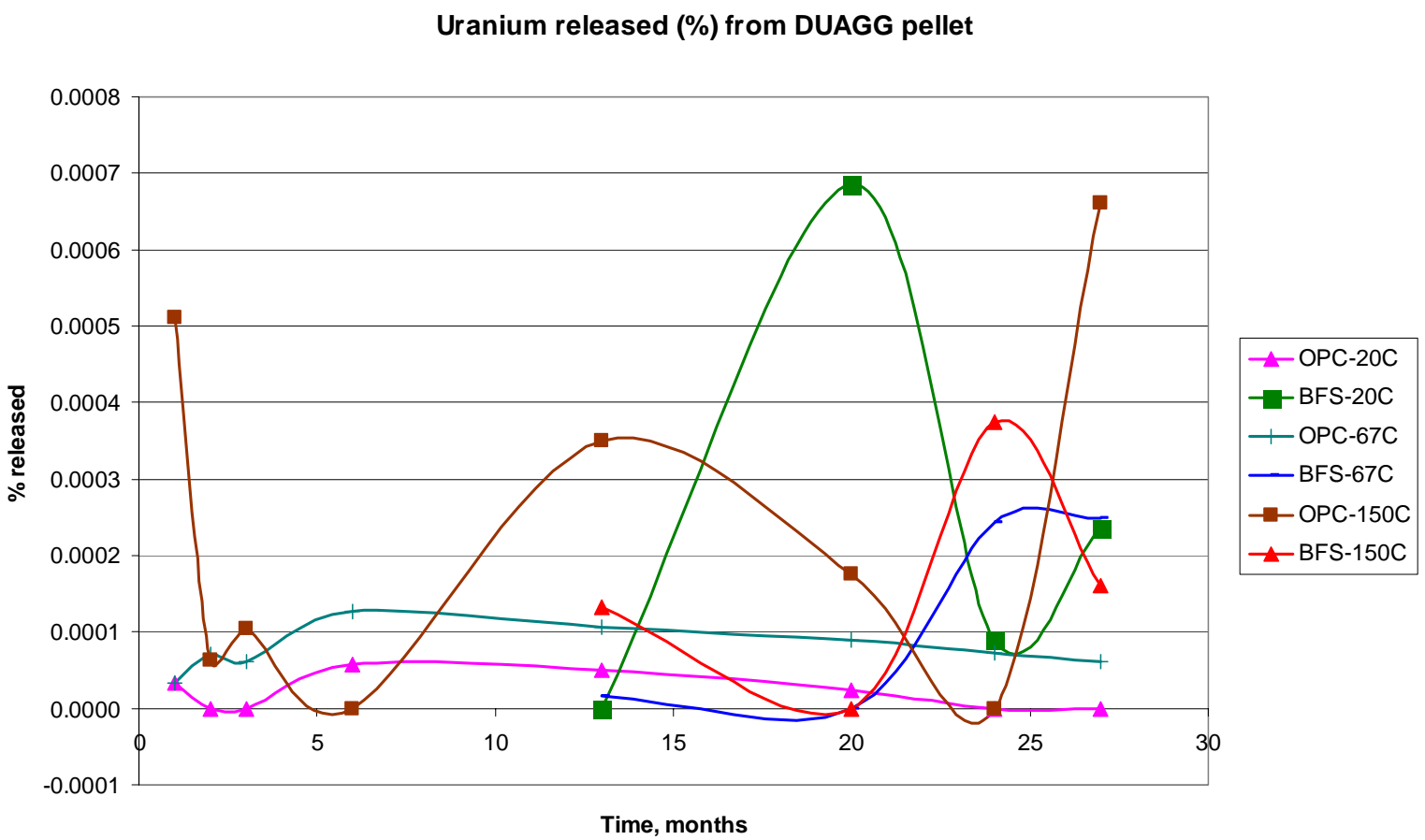

Fig. 6. Uranium fraction of the $\mathrm{U}$ leached from the basalt-sintered $\mathrm{UO}_{2}$ into blast-furnace slag (BFS) altered-cement and OPC porewaters at 20,67 , and $150^{\circ} \mathrm{C}$ for up to 26 months. The pattern of the slight rise and fall of the percentage of $U$ leached in the cement porewater is indicative of forming insoluble silicates in the dense hydroaluminosilicate phases that form on the UO2 surfaces. Source: Mattus, C. H. and L. R. Dole. 2003. "Durability of Depleted Uranium Aggregates (DUAGG) in DUCRETE Shielding Applications," International High-Level Radioactive Waste Management Conference, Las Vegas, NV, USA, American Nuclear Society, La Grange Park, IL, USA, 03/30/2003-04/02/2003.

In a literature study (Mattus, Gilliam 1994), it was found that by tailoring the concrete formulation, good retention of radionuclides was achieved by cementitious waste forms. Also, Glasser (1993) indicates that in the case of uranium-doped cements, the solubility in the short term is caused mainly by precipitation of hydrous oxides, but in the long term, the hydrated compounds that uranium form with calcium and silicon lower the solubility by orders of magnitude.

Further evidence shows a dense mat of alteration phases developed on the fuel surface, accompanied by depletion in the alkali and alkaline earth cations and $\mathrm{Si}$ in the leachate solution. The nature of these alteration phases and the sequence in which they appear on the fuel are similar to those observed in surficial weathering zones of natural uraninite deposits, with alkali and alkaline earth uranyl silicates being the long-term solubility limiting phases for uranium. The sequence observed is represented schematically in Fig. 7. The formation of this layer of alteration (or corrosion) products prevents further release of $\mathrm{UO}_{2}$ particles, hence leading to a drop in the $\mathrm{U}$ release rate (Shoesmith 2000). 


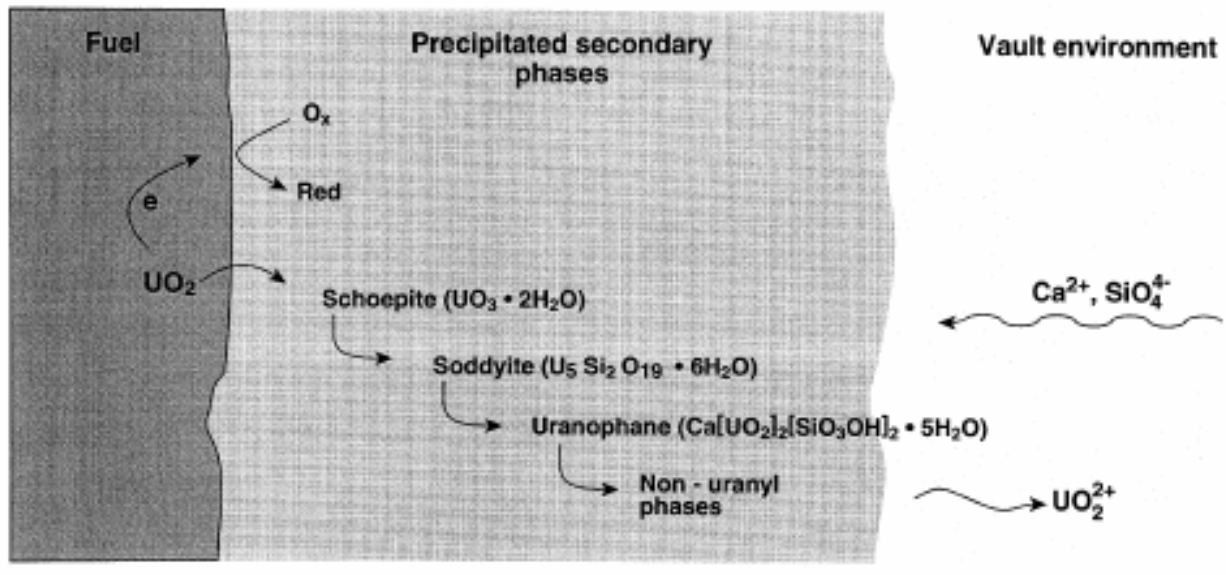

Fig. 7. Reaction sequence showing the alteration of precipitated uranyl phases observed in drip tests with unirradiated $\mathrm{UO}_{2}$ and expected from observations on surficial weathering zones on natural uraninite deposits. Source: Wronkiewicz, D.J.; J. K. Bates, S. F. Wolf, and E.C. Buck. 1996. J. Nucl. Mater. 238,78 .

Under oxidizing conditions, the U(IV) ions become incorporated into U(VI) deposits with very low solubilities, and the rapidity of the reduction of the corrosion rate by the addition of $\mathrm{Ca} / \mathrm{SiO}_{2}$ species suppress corrosion (Shoesmith 2000). This is consistent with electrochemical experiments which show that the incorporation of $\mathrm{Ca}$ and $\mathrm{Si}$ into U(VI) surface phases is very rapid and that only a few nm can suppress uranium oxide substantially. Corrosion experiments in the presence of $\gamma$-radiation fields show that the accumulation of secondary phases begins as soon as steady-state corrosion conditions are established.

At the proposed YM repository horizon, aerobic conditions will exist in YM. The oxidizing redox conditions and $\mathrm{pH}$ strongly affect the stability of uranium species that result from dissolved oxygen and the $\mathrm{pH}$ of the solution

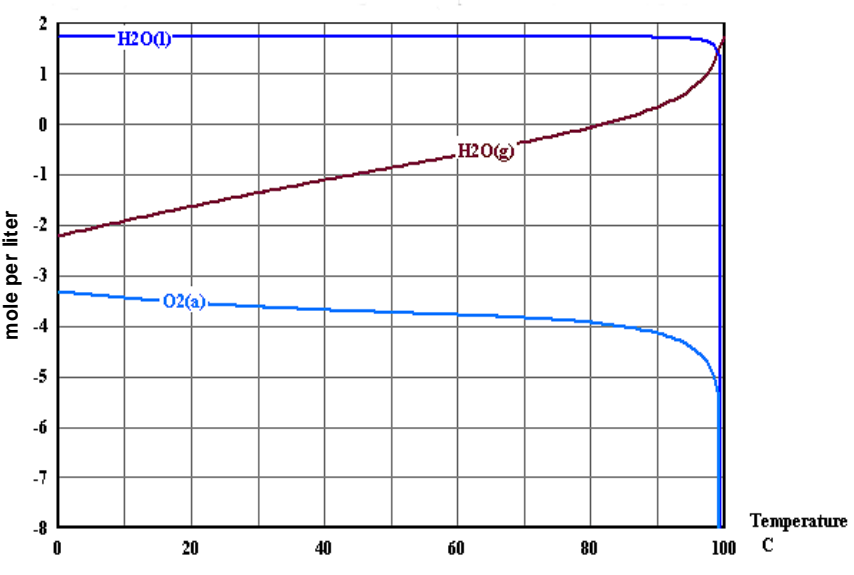

Fig. 8. With temperature, the solubility of $\mathrm{O}_{2}(\mathrm{~g})$ in groundwater influences the oxidative environment, along with $\mathbf{p H}$. At $25^{\circ} \mathrm{C}$, the solubility of oxygen is $\sim 3 \times$ $10^{-4} \mathrm{~mol} / \mathrm{L}$, using the HCS V5.1 code by Outokumpu Research Oy. (Fig. 8). The measure of reducing or oxidative conditions is described by Eh, an electromotive motive force (emf, volts) described by the Nernst equation for dissolved oxygen in water (Anderson 1996). 
From the Nernst equation, the relationship of Eh to dissolved $\mathrm{O}_{2}(\mathrm{a})$ and $\mathrm{pH}$ can be reduced to Equation 4 .

$$
\mathrm{Eh}=1.23+0.0148 \log f_{\mathrm{O}_{2}}-0.0592 \mathrm{pH}
$$

Where $f_{\mathrm{O}_{2}}$ is the dissolved oxygen fugacity.

Figure 9 shows the relationship Eh and $\mathrm{pH}$ for $\mathrm{O}_{2}(\mathrm{a})$ saturated groundwater given by Eq. 3 .

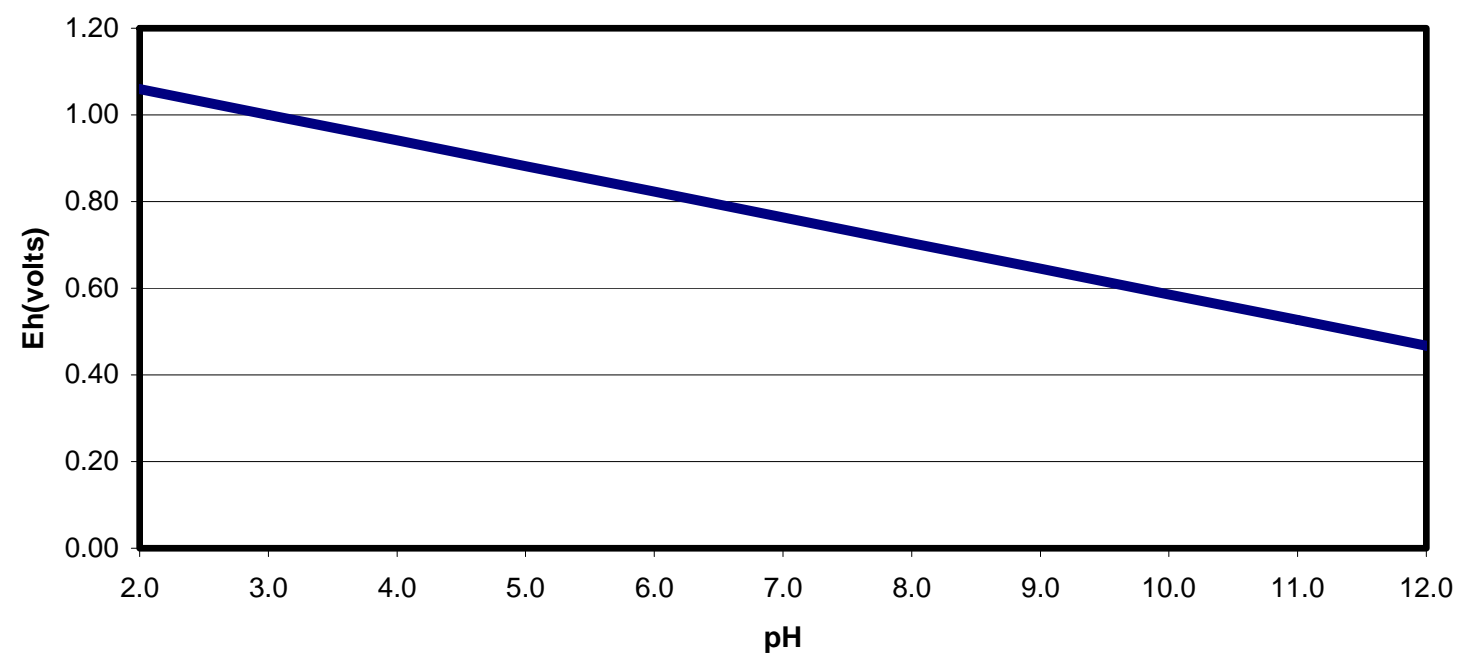

Fig. 9. When saturated $\mathrm{O}_{2}$ (a) controls the groundwater Eh (based on Eq. 4), the conditions are always oxidizing (Eh >0) over the expected $\mathrm{pH}$ ranges of the buffered YM repository groundwater.

Table 2 lists U(VI) species that can form under these Eh and $\mathrm{pH}$ conditions in the aerobic YM repository with calcium-silica saturation. For these major U(VI) species that have been observed, Table 2 also shows their Gibbs energies of formation, $G_{\mathrm{f}, 298}^{\circ}$ (Freeze, Cherry 1979; Bruton, Shaw 1988; Finch 1997; Chen et al. 1999).

Figure 10 shows that under aerobic condition in the YM repository U(VI) species are expected to form. Whereas, the expected Eh lies between 1.1 and 0.45 volts, and the $\mathrm{pH}$ is $<10$. Figure 10 also shows the compositional plots for typical groundwaters (Freeze and Cherry 1979) and for YM J-13 groundwater (Bruton and Shaw 1988).

The flat dashed lines in Fig. 10 represent quartz (lower) and amorphous silica (upper) equilibria. The mineral stability fields defined by the light dashed lines are based on the Gibbs energies for the minerals given by Finch (1997). If haiweeite and ursilite are included in the $\log \left(\left[\mathrm{Ca}^{+2}\right] /\left[\mathrm{H}^{+}\right]^{2}\right)$ vs. $\log \left[\mathrm{H}_{4} \mathrm{SiO}_{4}\right]$ diagram for the $\mathrm{SiO}_{2}-\mathrm{CaO}-\mathrm{UO}_{3}-\mathrm{H}_{2} \mathrm{O}$ system, the predicted stability fields for these phases replace most of the field for uranophane (Chen et al. 1999). 
Table 2. Values of $G_{f, 298}^{\circ}$ for the U(VI) minerals used in the construction of Fig. 10

\begin{tabular}{|c|c|c|c|}
\hline Uranyl phases & Formula & $\mathrm{kJoule} / \mathrm{mol}^{a}$ & kJoule/mol ${ }^{b}$ \\
\hline Metaschoepite & {$\left[\left(\mathrm{UO}_{2}\right)_{8} \mathrm{O}_{2}(\mathrm{OH})_{12}\right]^{*}\left(\mathrm{H}_{2} \mathrm{O}\right)_{10}$} & $-13,092.0$ & $-13,092.0$ \\
\hline Becquerelite & $\mathrm{Ca}\left[\left(\mathrm{UO}_{2}\right)_{6} \mathrm{O}_{4}(\mathrm{OH})_{6}\right]^{*}\left(\mathrm{H}_{2} \mathrm{O}\right)_{8}$ & $-10,324.7$ & $-10,305.8$ \\
\hline Rutherfordine & $\mathrm{UO}_{2} \mathrm{CO}_{3}$ & $-1,563.0$ & $-1,563.0$ \\
\hline Urancalcarite & $\mathrm{Ca}_{2}\left[\left(\mathrm{UO}_{2}\right)_{3}\left(\mathrm{CO}_{3}\right)(\mathrm{OH})_{6}\right]^{*}\left(\mathrm{H}_{2} \mathrm{O}\right)_{3}$ & $-6,036.7$ & $-6,037.0$ \\
\hline Sharpite & $\mathrm{Ca}\left[\left(\mathrm{UO}_{2}\right)_{6}\left(\mathrm{CO}_{3}\right)_{5}(\mathrm{OH})_{4}\right]^{*}\left(\mathrm{H}_{2} \mathrm{O}\right)_{6}$ & $-11,607.6$ & $-11,601.1$ \\
\hline Fontanite & $\mathrm{Ca}\left[\left(\mathrm{UO}_{2}\right)_{3}\left(\mathrm{CO}_{3}\right)_{4}\right] *\left(\mathrm{H}_{2} \mathrm{O}\right)_{3}$ & $-6,524.7$ & $-6,523.1$ \\
\hline Liebigite & $\mathrm{Ca}_{2}\left[\left(\mathrm{UO}_{2}\right)\left(\mathrm{CO}_{3}\right)_{3}\right]^{*}\left(\mathrm{H}_{2} \mathrm{O}\right)_{11}$ & $-6,446.4$ & $-6,468.6$ \\
\hline Haiweeite & $\mathrm{Ca}\left[\left(\mathrm{UO}_{2}\right)_{2}\left(\mathrm{Si}_{2} \mathrm{O}_{5}\right)_{3}\right] *\left(\mathrm{H}_{2} \mathrm{O}\right)_{5}$ & $-9,367.2$ & $-9,431.4$ \\
\hline Ursilite & $\mathrm{Ca}_{4}\left[\left(\mathrm{UO}_{2}\right)_{4}\left(\mathrm{Si}_{2} \mathrm{O}_{5}\right)_{5}(\mathrm{OH})_{6}\right] *\left(\mathrm{H}_{2} \mathrm{O}\right)_{15}$ & $-20,377.4$ & $-20,504.6$ \\
\hline Soddyite & {$\left[\left(\mathrm{UO}_{2}\right)_{2} \mathrm{SiO}_{4}\right] *\left(\mathrm{H}_{2} \mathrm{O}\right)_{2}$} & $-3,653.0$ & $-3,658.0$ \\
\hline Uranophane & $\mathrm{Ca}\left[\left(\mathrm{UO}_{2}\right)\left(\mathrm{SiO}_{3} \mathrm{OH}\right)\right]_{2} *\left(\mathrm{H}_{2} \mathrm{O}\right)_{5}$ & $-6,192.3$ & $-6,210.6$ \\
\hline \multicolumn{4}{|c|}{$\begin{array}{l}{ }^{a} \text { Source: } \\
\text { Ehen, F.; R. C., Ewing; and S. B., Clark. 1999. "The Gibbs Free Energies and Enthalpies of U }{ }^{6+} \text { Phases: An } \\
\text { Empirical Method of Prediction." American Mineralogist Vol. 84, pp 650-664. } \\
{ }^{b} \text { Source: Finch, R. J. 1997. "Thermodynamic Stabilities of U(VI) Minerals: Estimated and Observed Relationships, } \\
\text { Scientific Basis for Nuclear Waste Management XX," Materials Research Society Proceedings, W.J. Gray } \\
\text { and I.R. Triay, Eds., 465, pp. 1185-1192. }\end{array}$} \\
\hline
\end{tabular}

Because the uranyl oxide hydrates, $\left(\mathrm{UO}_{2}\right)_{\mathrm{x}}(\mathrm{OH})_{\mathrm{y}}$, are the first corrosion products to form on $\mathrm{UO}_{2}(\mathrm{Fig} 7)$, their paragenesis is the principal reaction path for uraninite corrosion (Finch 1997). Kinetics favor the early formation of $\left(\mathrm{UO}_{2}\right)_{\mathrm{x}}(\mathrm{OH})_{\mathrm{y}}$, such as schoepite (Table 2), which can apparently form from solutions with low silica. The presence of $\mathrm{Si}\left(10^{-3} \mathrm{M}\right)$ was shown to retard the transformation of schoepite to becquerelite in $10^{-2}$ and $10^{-3} \mathrm{M}$ Ca systems (Sowder et al. 1996). Even then, small inclusions (unidentified) of uranyl silicates occur within schoepite grains, suggesting that while low silica was present in the groundwater, the nucleation and growth was more rapid for schoepite than for other uranyl silicates. Therefore, the precipitation of uranyl silicates directly from solution requires a large over saturation as shown in Figs. 2 and 3. This will happen when high-silica conditions exist from the presence of pozzolan-modified OPC and the tuffaceous YM formations. Also, the 1:3 silicates (the "haiweeite group," see Table 1) are only known from Si-rich environments such as tuffaceous rocks, where weeksite is also common. The presence of uranosilite is another indication of higher Si concentrations.

A literature study by Mattus and Gilliam (1994) found that by tailoring the concrete formulation, good retention of radionuclides was achieved by cementitious waste forms. Also, Glasser (1993) indicates that in the case of uranium-doped cements, the solubility in the short term is caused mainly by precipitation of hydrous oxides, but in the long term the hydrated compounds that uranium form with calcium and silica lower the solubility by orders of magnitude. Glasser also found that uranium is in the U(VI) oxidation state in the cement matrix. 


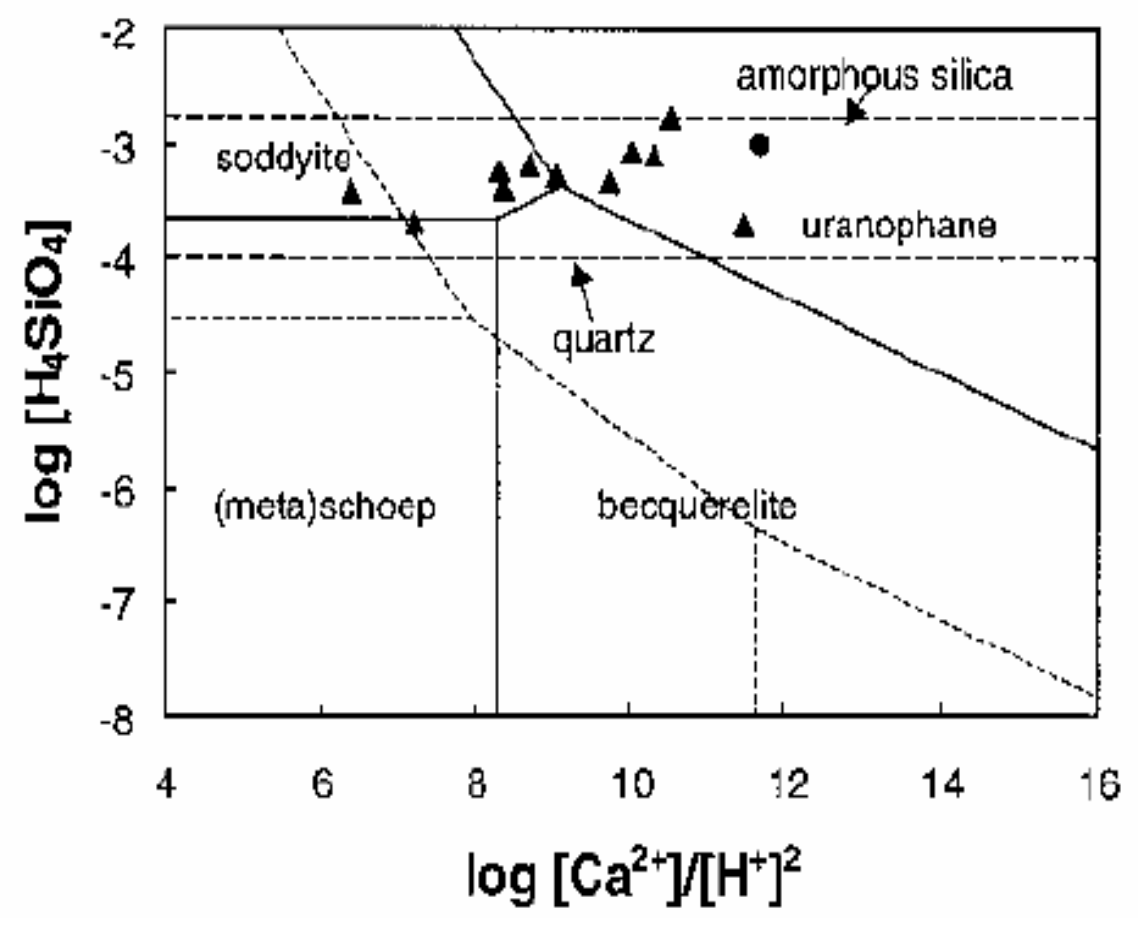

Fig. 10. Activity-activity diagram for the system $\mathrm{SiO}_{2}-\mathrm{CaO}-\mathrm{UO}_{3}$ $\mathrm{H}_{2} \mathrm{O}$, constructed excluding swanboite, uranosilite, haiweeite, and ursilite with the composition typical groundwaters from crystalline rocks and for YM J-13. Triangles from Freeze and Cherry (1979) and circles are from Bruton and Shaw (1988). ${ }^{a}$ Source: Chen, F.; R. C., Ewing; and S. B., Clark. 1999. "The Gibbs Free Energies and Enthalpies of $\mathrm{U}^{6+}$ Phases: An Empirical Method of Prediction." American Mineralogist Vol. 84, pp. 650-664.

The excess silica can also react in the adjacent porewater, modifying its composition to reduce the potential of forming corrosive brines as seeps drip and evaporate on the hot waste packages. Strong evidence exists that the silica-saturated concrete leachates will aid in passivating the metal surfaces of the WPs by suppressing the localized galvanic corrosion that can form from surface inhomogeneities in the alloy (Fig. 11). Silicates react with dissolved metal ions at anodic sites on the metal's surface. The resultant insoluble silicate complex forms a nonconductive gel that deposits on the metal surfaces at these anodic sites (Fig. 12). This insulating gel forms a thin, adherent layer that is relatively unaffected by $\mathrm{pH}$ in comparison to other corrosion inhibitors. The silicates' inhibiting properties actually increase with temperature and $\mathrm{pH}$; the $\mathrm{pH}$ levels can be up to 9.5 to 10.5 . 


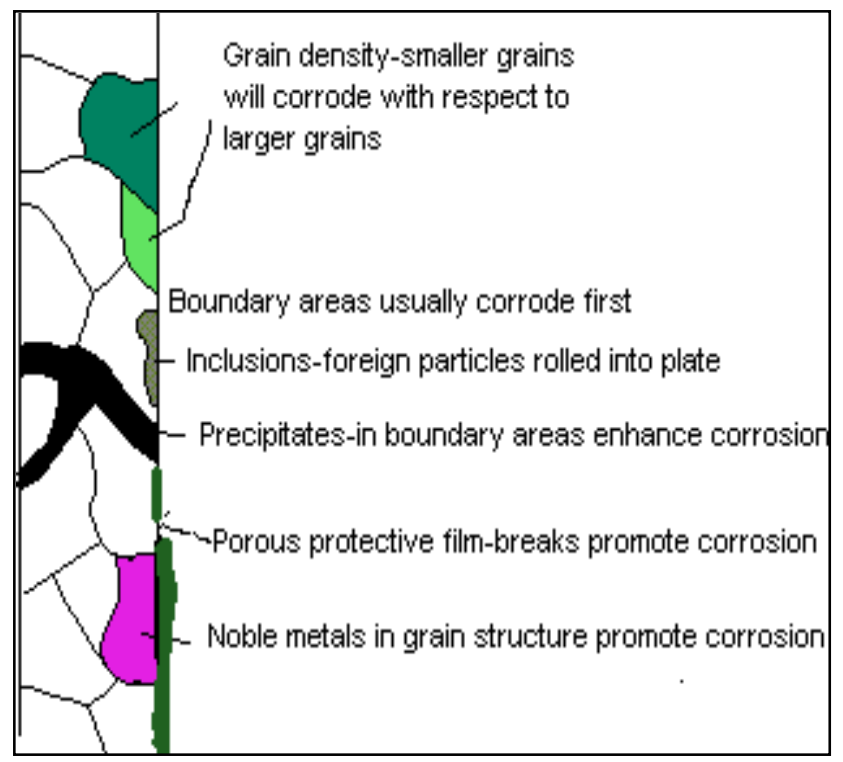

Fig. 11. Galvanic cells can form on the surface of metals through various mechanisms associated with small inhomogeneities. Source: Marine Engineering Organization. UK. 2004. "Corrosion Inhibitors Used in Jacket Water System." http://www.marineengineering.org.uk/motjktwtr/motc orinhibMain.htm.

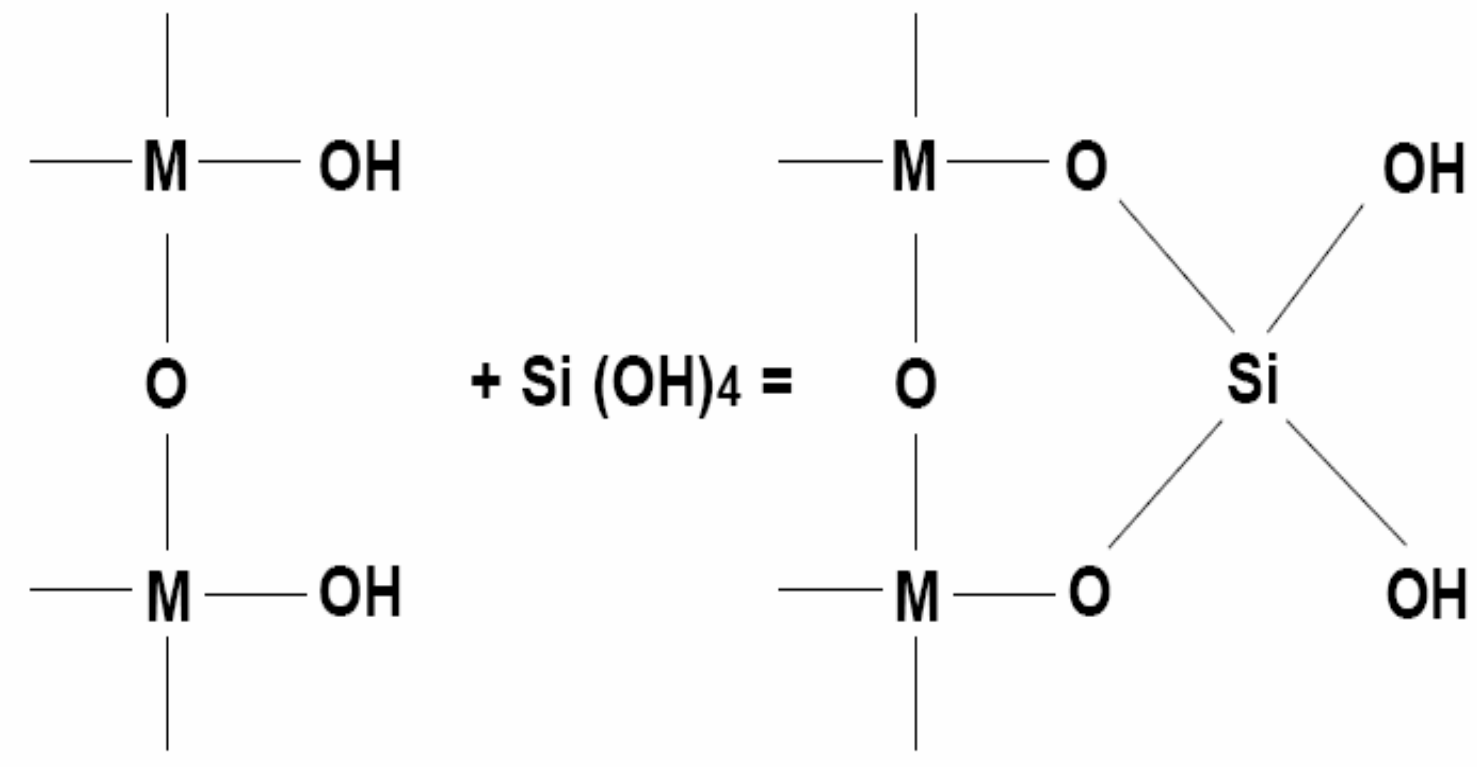

Fig. 12. When the silica leached from the adjacent high-silica concrete structures contacts the WP's metal surface, monomeric silica adsorbs onto metal surfaces at the anodic sites, forming a thin, insulating monomolecular film, preventing any further corrosive reaction at the anode. Source: PQ Quartz. 2004. Bulletin 37-3, "PQ® Soluble Silicates: For Protection of Water Systems From Corrosion.” P.O. Box 840, Valley Forge, PA 19482-0840. 
So contrary to the YMP concerns, high-silica concretes will decrease the mobility of uranium and its associated radionuclides. High-silica, cement-based concretes reduce the solubility, dissolution, and transport of uranium oxides and their constituents, while prolonging the expected lives of the metal waste packages.

\section{Fine Pore Distribution in High-Silica Cements Reduces the Release of Moisture}

The YMP was concerned that the water of hydration in concretes would increase the humidity in the tunnels and drifts and promote corrosion of the WPs.

The additions of ASTM Class F fly ash, silica fume, and blast furnace slags to OPC can result in lowering the matrices' permeabilities to $<3 \times 10^{-12} \mathrm{~cm} / \mathrm{s}$. In addition, these silica additives greatly reduce the pore sizes and the pore volumes. Adding $>30 \%$ by weight of pozzolan to OPC at a water-to-cement weight ratio (W/C) approaching 0.25 results in a matrix with a critical pore radius ${ }^{\mathrm{a}}$ is between 0.04 and $0.01 \mu \mathrm{m}$ (Hooton 1986) and a porosity approaching 6 vol \% (Massazza 2004). At 28 days of curing, OPCs have critical pore radii between 1 and $0.1 \mu \mathrm{m}$.

Saito and Deguchi (2000) measured the effects of granulated blast furnace slags on the distribution of pore sizes in mortars (only fine aggregate) (Fig. 13). The characteristics of the cement hydrate structure reflect differences in mix proportions and pozzolanic admixture. In particular, pozzolanic admixture replacement decreases $\mathrm{Ca}(\mathrm{OH})_{2}$ content to from a tight cement hydrate structure (Saito and Deguchi 2000). Pozzolanic admixture replacement for a part of the cement is very useful for mix proportion design of a durable concrete that resists leaching and shows small loss of performances after leaching.

In another example, a 30\% substitution of silica fume for OPC can reduce the pore volume by $50 \%$ (Malhota et al. 1987). The porosity in high-silica cements is relatively closed-cell porosity, having dense silica-hydrogels that constrict the connections between the pores. These constrictions result in very low hydraulic conductivities $\left(<3 \times 10^{-12} \mathrm{~cm} / \mathrm{s}\right)$ and low critical-pore diameters (between 0.04 and $\left.0.01 \mu \mathrm{m}\right)$.

The pore volume and pore size distribution are important because the vapor pressure at equilibrium with the pores of a cement matrix depends on the curvature of the porewater surface. For such a capillary system, the equilibrium vapor pressure described by the Kelvin equation (Eq. 4), is proportional to $\mathrm{e}^{-(1 / \mathrm{r})}$, where $r$ is the pore radius (Soroka 1980A).

$$
\ln \left(\mathrm{p}_{\mathrm{v}} / \mathrm{p}_{\mathrm{w}}\right)=-2 \sigma /\left(\mathrm{r} \rho_{\mathrm{w}} \mathrm{RT}\right)
$$

where

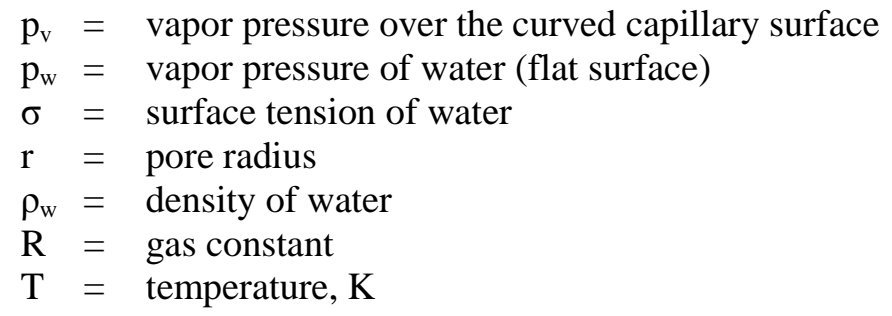

This means that the vapor pressure of the cement capillary water is very low when compared with other water that may seep into the tunnels from the adjacent YM formation. Conversely, it takes an extremely low humidity to desiccate the cement paste in high-silica cements.

a The critical pore radius is the pore radius at which the cumulative pore distribution curve has the highest slope (i.e., the highest population). 


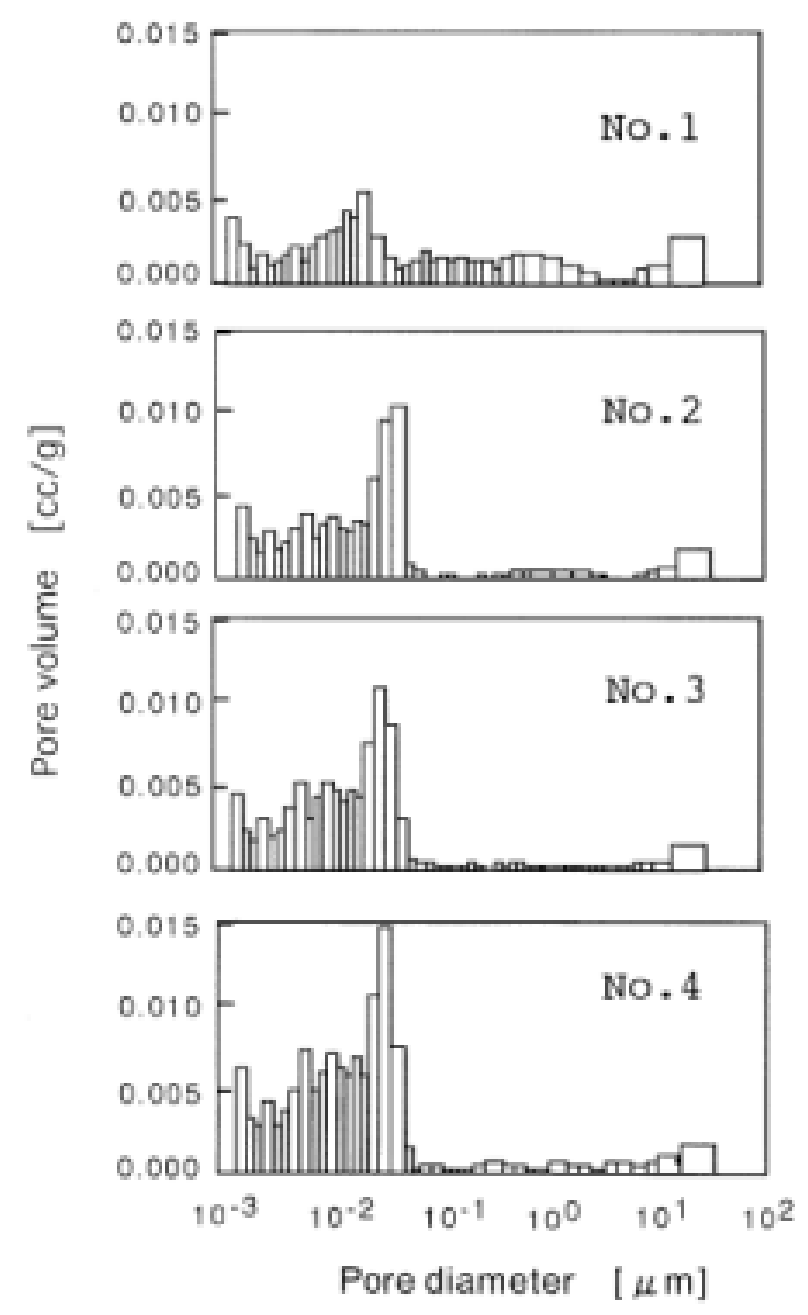

Fig. 13. (a) These plots show the pore size distributions in normal sand (quartz) filled cement mortars. Source: Saito, Hiroshi and Akira Deguchi. 2000. "Leaching Tests on Different Mortars Using Accelerated Electrochemical Method." Cement and Concrete Research 30, pp. 1815-1825.

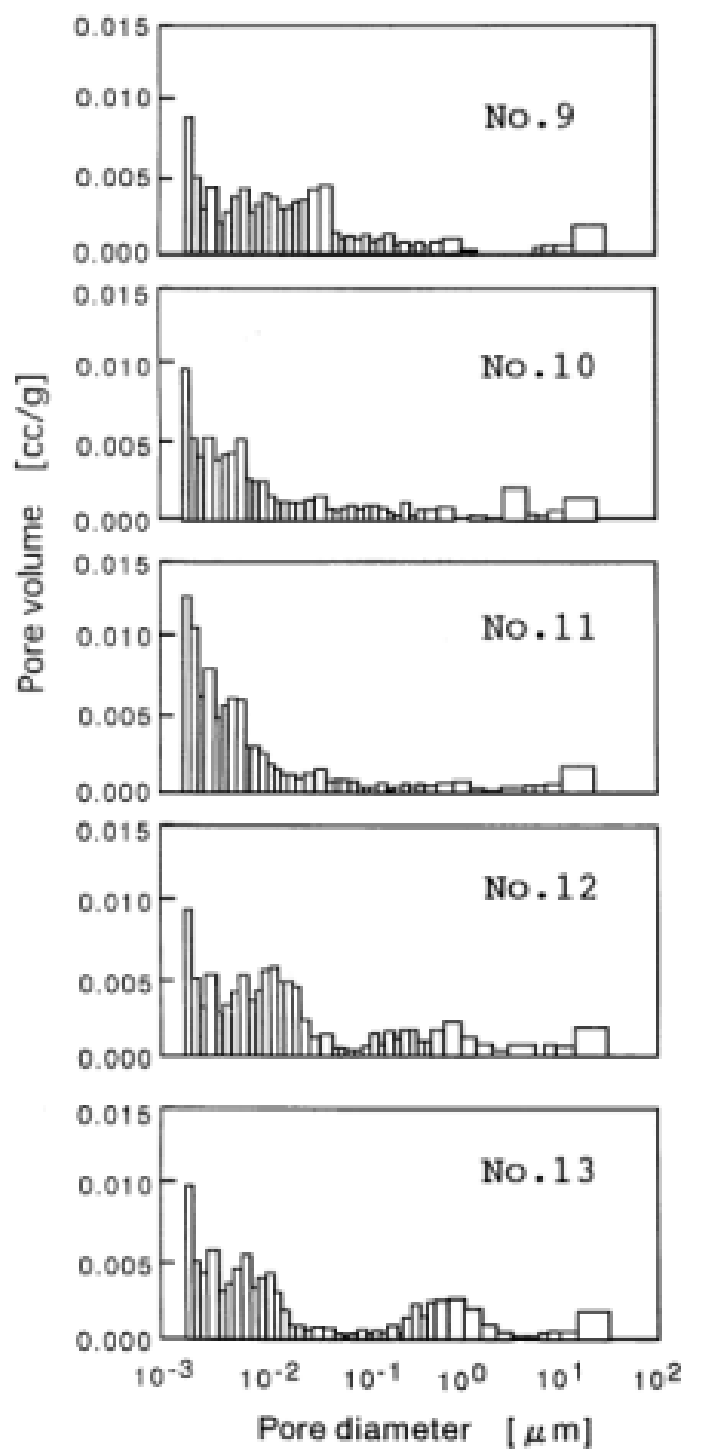

Fig. 13. (b) Additions of blast furnace slag and silica fume (pozzolans) significantly reduce the pore sizes in cement mortars. Source: Saito and Deguchi 2000. 
Glasser and Hong

(2003) compared treatments at 25,130 , and $200^{\circ} \mathrm{C}$ (Fig. 14).

Very little of the remaining water can be removed upon subsequent drying at $<105^{\circ} \mathrm{C}$. The amount of water retained to higher temperatures, $>105^{\circ} \mathrm{C}$, is therefore substantial and is in theory sufficient to form all but the more highly hydrated crystalline phases of the $\mathrm{CaO}-\mathrm{SiO}_{2}-\mathrm{H}_{2} \mathrm{O}$ system. Silica can be added in reactive form (e.g., as quartz flour, fly ash) to lower the bulk $\mathrm{Ca} / \mathrm{Si}$ ratio to $0.8-1.5$. This leads to development of phases such as tobermorite, xonotlite and possibly afwillite, which enable better strength retention and reduced solubility in an aqueous phase, relative to either OPC

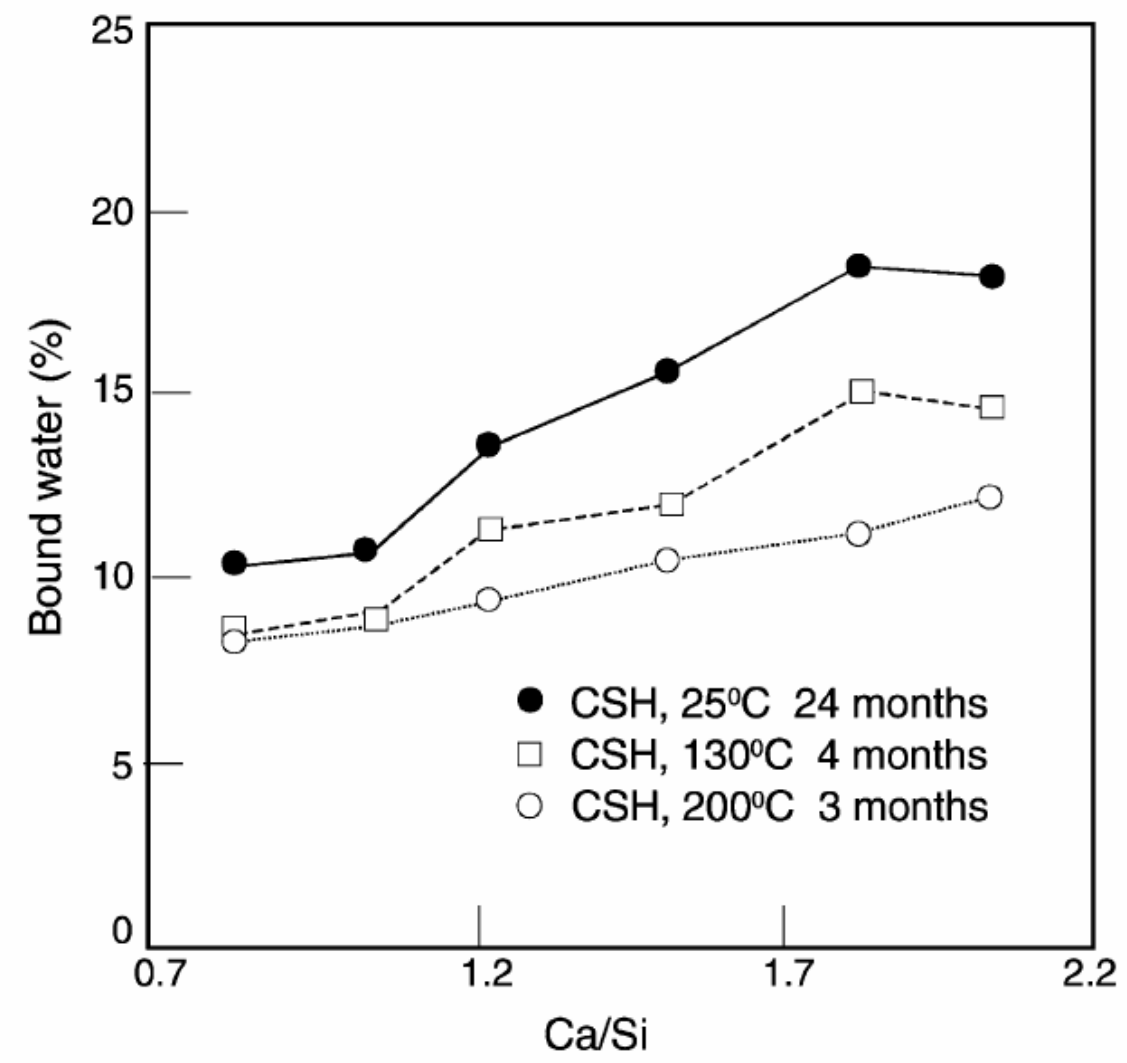
or $\mathrm{Ca}(\mathrm{OH})_{2}$ (Taylor 1990).

In comparison, the texture of the Topopah Spring welded unit (Montazer and Wilson 1984) consists of a very thin upper vitrophyre, a thick central zone consisting of several densely welded, devitrified ash-flow sheets, and a thin lower vitrophyre ${ }^{\mathrm{a}}$. The unit contains several lithophysal ${ }^{\mathrm{b}}$ cavity zones of varying thickness, and the rocks are intensely fractured. This unit is the thickest and most extensive of the Paintbrush Group and contains the central-lower, densely-welded devitrified-zones being considered for the potential repository. The subunits typically have porosities between 9 and 14 vol $\%$ (Flint 1998).

Therefore, high-silica concretes will not contribute significant additional humidity to the drift and tunnel. The finely textured, impermeable high-silica cements will bind moisture more tightly than the adjacent vitreous tuff formation.

\footnotetext{
${ }^{a}$ Vitrophyre is a glassy igneous rock.

${ }^{\mathrm{b}}$ Lithophysal is a condition of having large glassy bubbles, usually in basalt or rhyolites, also known as stone bubbles.
} 


\section{Silica-Saturated Cement Leachates Will Not Dissolve Adjacent Vitreous Tuff}

The YMP was concerned that the porosity, permeability, and transport properties of the adjacent formation could be altered by concrete leachates and lead to higher transport rates of nuclides.

YM groundwater ranges in silica concentrations between $61 \mathrm{ppm}\left(\sim 6.5 \times 10^{-4} \mathrm{M}\right)$ for the $\mathrm{J} 13$ well and $46 \mathrm{ppm}\left(\sim 1.1 \times 10^{-4} \mathrm{M}\right)$ for the unsaturated zone (UZ) groundwater in the adjacent vitreous tuff (Rosenberg et al. 2001). The formation above the repository horizon is an unfractured vitreous tuff, the Paintbrush (PTn) hydrostratographic unit (Flint 1998). This is a welded unit of the Tonopah Springs Tuff (Sonnenberg and Bodvarsson 1999). The groundwater in equilibrium with this UZ tuff has much lower concentrations of soluble silica $\left(10^{-4} \mathrm{M}\right)$ than has the collective concentrations of silicates $\left(>1 \times 10^{-3} \mathrm{M}\right)$ that are in equilibrium with pozzolanic glass (Fig. 2 and Fig. 3).

Therefore, cement leachates will be supersaturated in silica species as it mixes with the native groundwaters in the adjacent pores of the tuff. These silicates will precipitate in the adjacent pores, reducing the local permeability. Similar to that expected for the thermo-hydraulic changes, Nitao (1999) found that thermally driven silica deposition will modify hydrologic properties of the rock mass in the vicinity of waste-emplacement drifts (i.e., reduce hydraulic conductivity) and that these changes are large and irreversible.

Therefore, these silica precipitates from cement leachates would also reduce the porosity, permeability, matrix, and fracture saturation in the vicinity of waste-emplacement drifts. In addition, uranium and associated radionuclides will be converted to insoluble, immobile phases.

YMP's concern about the transport of uranium and nuclides can be resolved through the use of high-silica cements that will decrease transport within the adjacent YM formation. Because silica-saturated cement leachates will reduce the concentration of soluble species and reduce the permeability at the contact zone of the cement and vitreous-tuff, less uranium will be available for transport, and it will move at a slower rate than assumed by the early concerns.

\section{Pozzolanic Additives Are Water-Reducing Agents and Minimize the Need for Surfactants}

The YMP was concerned that the introduction of organic surfactants as water-reducing superplasticizers into the concrete mix could form organic acids, thereby stabilizing colloids and resulting in an increase in the radionuclide transport from the repository.

To increase strength and to minimize permeability and porosity, a water-to-cement ratio approaching the ideal of 0.25 is needed. However, the mix must still maintain workability and emplacement qualities to produce an acceptable concrete. Therefore, to minimize the use of organic surfactants (superplasticizers), pozzolans will be selected that also function as water reducers, such as ASTM Class F fly ash, blast furnace slag, and silica fume (Ramachandran 1984, ACI 233R-03 2004, ACI 211.1-97).

$\mathrm{Wu}$ and Roy (1982) found that pastes containing slag showed different rheological properties when compared with pastes of OPC alone. Fulton (1974) investigated workability in great detail and suggested that a cementitious matrix containing slag cements exhibited greater workability because the increased paste-silica content increased cohesiveness of the paste. Wood (1981) reported that the workability and placeability of concrete containing slag cement was improved when compared with concrete containing no slag. He further observed that this result was due to the surface characteristics of the slag cement, which created smooth slip planes in the paste. He also theorized that, due to the smooth, dense surfaces of the slag particles, they absorbed little if any water during initial mixing, unlike OPCs. His results indicate a better particle dispersion and higher fluidity of the pastes and mortars, both with and without waterreducing admixtures. Concrete containing slag cement is consolidated under mechanical vibration more easily than concrete that does not contain slag cement. 
If surfactants are needed to achieve workable mixtures with low mix water, non-ionic surfactants will be chosen so that they will be limited to $<0.5 \mathrm{wt} \%$. Also, non-ionic surfactants will be chosen, such as unsaturated polyols ${ }^{\mathrm{a}}$, to minimize the potential for the surfactant-superplastizer to hydrolyze into organic acids, which could form chelating agents and mobilized radionuclides.

In order for any organic molecules in the cement paste to have any effect, they must first diffuse through the cement and aggregate matrices to the surface of the concrete. There may be some hydrolysis products from the small amount of surfactants in the cement paste, the diffusion coefficients for small organic molecules have been measured at $\sim 1 \times 10^{-6} \mathrm{~cm}^{2} / \mathrm{s}$ for chloroform, $\sim 3.5 \times 10^{-8} \mathrm{~cm}^{2} / \mathrm{s}$ for acetone, 1,2dichloroetylene, and benzene, and $\sim 3 \times 10^{-9} \mathrm{~cm}^{2} / \mathrm{s}$ for chlorobenzene and percloroethene (Spence et al. 1992). For larger organic molecules, the diffusion coefficients are as low as $1 \times 10^{-12}$ to $1 \times 10^{-15} \mathrm{~cm}^{2} / \mathrm{s}$ (Dole 1991; Dole et al. 1993). Because the rates at which organic molecules diffuse to the high-silica concrete surface are so low, they are not likely to affect the solubilities of uranium and its associated radionuclides. (These low diffusion rates also do not allow potential organic nutrients to diffuse to the surface of the concrete and prevent biological growth.)

So while pozzolans minimize the need for superplasticizers by lowering the mix viscosity and the water requirements for workability (Malhota et al. 1987), the pozzolans also develop an impermeable matrix (Hooton 1986). This impermeable matrix also retards the release of any organic hydrolysis products.

\section{High-Silica Cements Limit the Bioavailability of Nutrients}

The YMP was concerned that the organics and calcium sulfate hydrate $\left(\mathrm{CaSO}_{4} \cdot 2 \mathrm{H}_{2} \mathrm{O}\right.$, gypsum $)$ contained within the concrete could provide nutrients and a substrate for microbiological growth that would in turn accelerate the corrosion of the waste package and increases the availability and transport of nuclides.

Man-made pozzolanic structures have persisted for up to 6,000 years in a broad range of terrestrial, fresh water, and marine environments (See the discussion of the proposed study of ancient and natural cementanalogs in following sections). Also, naturally formed cementitious materials have been weathering for 10's of millions of years (Petit 1992). This archaeological and geological record is evidence that these materials can have significant resistances to degradation by biological mechanisms.

However, cementitious materials can be a substrate for colonies of a wide variety of algae, bacteria, fungus, molds, and lichens, but cement matrix components themselves are very rarely food for these colonies. Cases of surficial concrete degradation result from attack by the acids and enzymes produced by the metabolism of these colonies. However, these microorganisms must receive their nutrients from an external source, such as sewage, rainwater, or the deposition of airborne industrial pollutants (Herrera et al. 2003). Also, the Portlandite in OPC surfaces reacts with ambient $\mathrm{CO}_{2}$ or $\mathrm{HCO}_{3}{ }^{-}$to form calcite $\left(\mathrm{CaCO}_{3}\right.$, limestone) that seals the surface and seals the internal matrix from the colonies that inhabit the surface. Conversely, lichen only grow on OPC surfaces after a period of exposure to $\mathrm{CO}_{2}$ that carbonizes the concrete surface and seals the lichen from the high $\mathrm{pH}$ of the Portlandite embedded in the cement paste matrix (Rosato and Treversa 2000).

Because of their low porosity and permeability, pozzolans severely limit the rate that potential nutrients can diffuse to the surface of the concretes and are the least likely of the cementitious materials to supply food for biological colonies on their surfaces. Surface colonies can produce organic acids and amino acids, which can etch their substrate. However, pozzolanic additives eliminate free Portlandite (Onofrei

\footnotetext{
${ }^{a}$ Polyol surfactants are made by reacting its ethylene oxide with fatty alcohols, alkyl phenol, amines and/or other chemicals to produce a broad range of surface-active chemicals. These non-ionic surfactants make up about twothirds of the world's current market.
} 
and Gray 1989) $\left(\mathrm{Ca}(\mathrm{OH})_{2}\right)$, preventing acid dissolution of the $\mathrm{Ca}(\mathrm{OH})_{2}$ (Pinheiro and Silva 2003), which is the principal mechanisms for surficial degradation. Also, the low permeability of high-silica cements prevents the diffusion of biological metabolites into it and prevents degradation.

As seen from the previous discussion, for any organic molecules or sulfate ions in the cement to become food for biota on the surface, that compound must first diffuse through the cement and aggregate matrices to the surface of the concrete. The diffusion coefficients are very small even for small organic molecules (Spence et al. 1992, Dole 1991, Dole et al. 1993). Because these diffusion rates are so low, high-silica concretes cannot support colonies without an external source of nutrients. Also, the impermeability and low diffusion rates retard mechanisms by which metabolites, salts, and acids can penetrate and disrupt these matrices (Glasser et al. 1987, Massazza 2004, Gaal et al. 2003).

In order to minimize the potential for biological degradation, researchers must take care to formulate YMP concretes with a minimum of potential nutrients. Components must be chosen to minimize the surfactant and sulfur contents of the Portland cement, slags, and pozzolans mixture for use in the YMP. To further ensure the suitability of the formulations chosen for use in the YM repository, they must be subjected to the testing protocol suggested by Rogers and others (2003), inoculating the test specimens with flora and fauna expected to be present in the YM repository. This testing protocol overcomes the limitations of the ASTM and Nuclear Regulatory Commission (NRC) accelerated microbial degradation tests.

\section{Natural and Anthropogenic Analogs Can Predict Long-Term Performance}

Natural, historical, or archaeological materials can be considered to be good analogs (Ewing 1979), while their use has been quite limited in the past for the design of matrices, both qualitative and quantitative information of great (and in some cases unique) interest has already been inferred for assessing their longterm performance (Petit 1992B). For example, several historical and archaeological cements (notably Roman and Gallo-Roman cements) have been studied as analogs of cement-based matrices (Rassineaux et al. 1989, Jull and Lees 1990).

Although most of these materials were made with a different technology than that used currently, similar constituents (hydrated calcium silicates, ettringite, etc.) can be found. Accepted guidelines must be followed for selecting samples and interpreting results of these tasks (Chapman et al. 1984, Petit 1992A, IAEA 1989).

A comparison of these studies with current cement-ageing models will bridge these proposed laboratory studies to the characterization of ancient cements and natural analogs. Through these comparisons, an attempt should also be made to extrapolate the predicted performance and the long-term source term to the time frames of the YMP risk models 


\section{RESEARCH NEEDS}

This program identifies research tasks that are required to realize the reduction of the underground construction cost by 100s of millions of dollars and significant improvements in the repository's performance through the applications of high-silica cements. This encompasses the (1) selection of local materials, (2) formulation of high-silica cements that meet the chemical and physical specification for use in YM, as determined by specific underground construction technologies, (3) precise characterization and exhaustive exposure testing of this series of high-silica cement formulations, (4) examination and comparison of ancient anthropomorphic and natural analogs with modern formulations, and (5) reduction and merging of this data into information to support the application of these formulation in the underground construction at YM.

\section{Need 1: Develop and Test Cost-Effective, High-Silica Cementitious Materials for Construction Of Yucca MOUNTAIN (YM) INVERTS, DRIFT LINERS, AND BULKHEADS.}

High-silica cementitious materials with admixtures can be designed to generate reducing Eh conditions, and prevent the formation of high-pH leachates. These modified concretes will slow the rate of waste package corrosion, and retard radionuclide migration, while remaining compatible with other YM repository systems. Importantly, these materials will be cost-effective, strong, and more durable than OPC and will avoid the issues that have previously limited the use of OPC in the current YM design. Building out the repository with these cementitious materials will, therefore, reduce the costs and will increase confidence in short- ( 10,000 year) and long-term ( $>100,000$ year) repository performance. Through (1) formulation studies, (2) the proposed testing protocols, (3) the study of anthropogenic and natural analogs, and (4) the applications of aging models, this study could present evidence to support a claim for liner performance that may reach 10,000 years.

Research should focus on cement formulations employing high-silica additives and aggregate materials with well-known performance characteristics and established engineering testing procedures. However, a possible future candidate material, the Topapah Springs Tuff formation, at the proposed repository level is itself a high-silica material (about $76 \% \mathrm{SiO}_{2}$ ), is remarkably uniform in chemical composition, and contains abundant vitreous material (Peterman and Cloke 2002).

Therefore later, if high-silica cements prove to be acceptable construction materials, future studies in this program could investigate the use of finely ground and coarse aggregate tuff removed by on-site tunnel boring equipment for the formulation of acceptable cements for the specific applications discussed in this report, as well as backfill grout for various applications associated with repository development and closure.

The principal objectives are to replace the current steel-sets drift construction in Fig. 15 with high-silica concretes that (a) reduce costs,(b) accelerate schedule,(c) improve durability, (d) contribute to protection of the waste packages, and (e) retard migration of radionuclides from the repository. 
The current driftconstruction is built with steels sets with a steel mesh for ground control and with rock bolts in the rock in unstable zones. To support the rails for the transport of waste packages, the invert systems on the tunnel floors are also built of steel lattice (Fig. 15).

In addition to having long-term durability superior to steel, the replacement of the current YMP steel tunnel support system with the application of high-silica cements to the build-out and lining of the YM repository connecting tunnels and disposal drifts will also result in potential cost savings of $\$ 112 \mathrm{M}$ or more in construction costs.

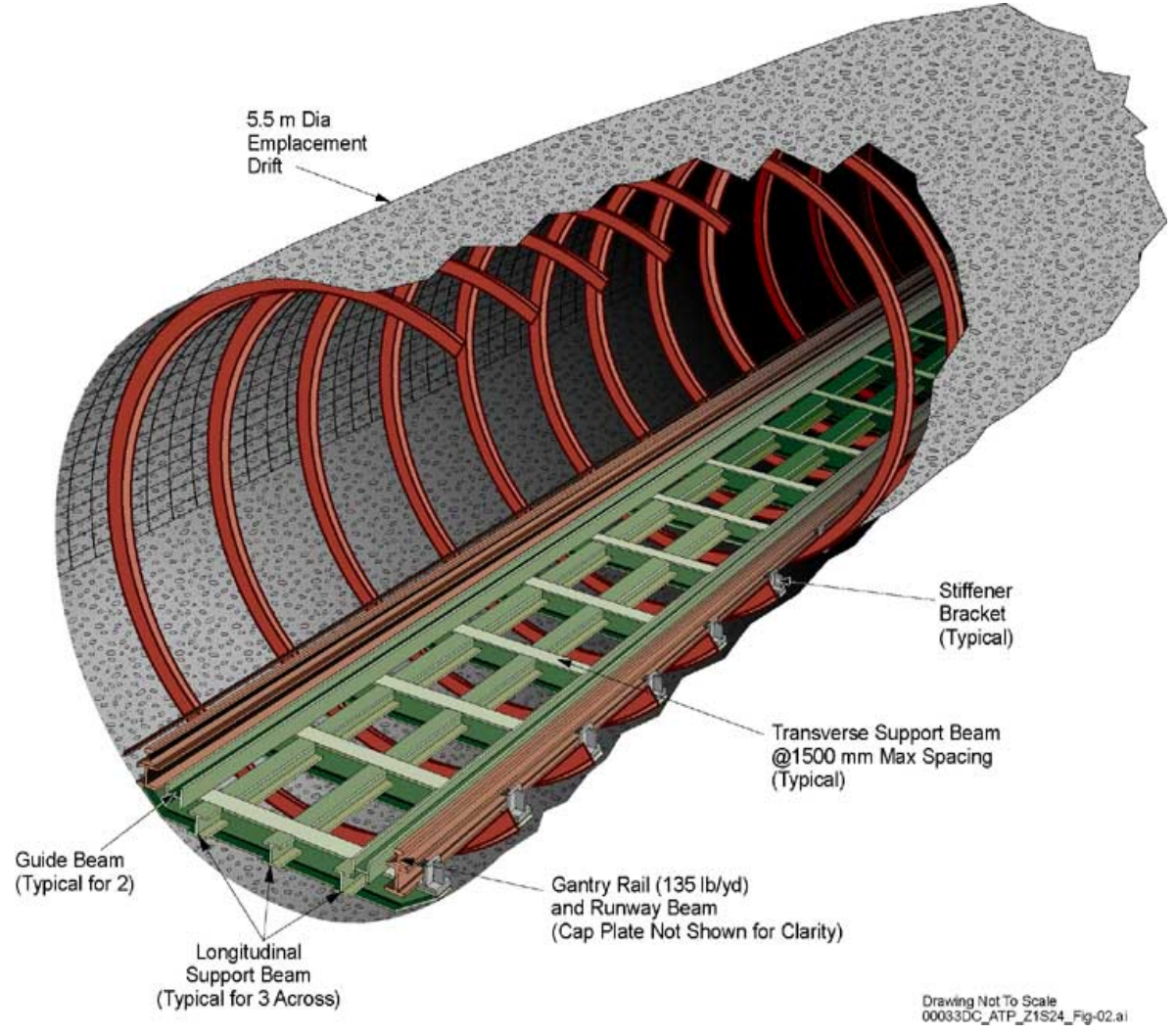

Fig. 15. Current YMP baseline underground tunnel build-out construction technology.

In order to give the YMP designers a broad selection of underground construction options, this study should develop and test a suite of high-silica concrete formulations that will be compatible with the following final YM tunnel lining alternatives, as well as an alternative invert system:

1. Cast-in place concrete;

2. Precast, prestressed high-strength concrete segments;

3. Vibratory, roller compacted high-strength concrete (for inverts and roadbeds); and

4. Shotcrete with or without microreinforcement (latter recommended).

The Table 3 summarizes some applications for the initial YM tunnel support. 
Table 3. Tunnel initial support alternatives

\begin{tabular}{lcl}
\hline Type of initial support & Possible applications \\
\hline Steel ribs with or without mesh and/or shotcrete & $\bullet$ Tunnel-boring machine starter tunnels \\
& $\bullet$ Fault and shear zones \\
Cast-in-place concrete & - Tunnel-boring machine starter tunnels \\
Shotcrete, light mesh, and rock bolts as required & - Starter tunnels \\
& - Connecting tunnels and disposal drifts \\
Precast concrete segments & - Boring machine tunnels \\
\hline
\end{tabular}

The selection of the preferred alternative will depend on the cost, initial support system compatibility, tunnel excavation method, and contractor experience (Boyle SD-S241-310-11, 2002). Table 4 summarizes some lining alternatives for the final support and finishing for the YM repository tunnels and disposal drifts.

Table 4. Final YM disposal drifts and connecting tunnels lining alternatives

\begin{tabular}{|c|c|}
\hline Type of final lining & Applications \\
\hline Cast-in-place concrete & $\begin{array}{l}\text { - } \quad \text { Tunnel-boring machine and drill and blast tunneling } \\
\text { - } \quad \text { Compatible with all initial support systems } \\
\text { - } \quad \text { May be done with light reinforcement in good rock } \\
\text { - Tunnel-boring machine starter tunnels }\end{array}$ \\
\hline $\begin{array}{l}\text { Precast concrete } \\
\text { segments }\end{array}$ & $\begin{array}{l}\text { - Compatible only with tunnel boring machine excavation } \\
\text { - Potential for high-speed and lower-cost installation } \\
\text { - Use as both initial and final lining }\end{array}$ \\
\hline Shotcrete & $\begin{array}{l}\text { - Applicable to tunnel-boring machine and drill and blast tunneling } \\
\text { - Combine with rock anchors, wire mesh, and steel fiber microreinforcement, as } \\
\text { needed }\end{array}$ \\
\hline
\end{tabular}

Fig. 16 illustrates the principal applications (above) for which the formulas in this study are aimed. These applications are (1) precast segments, (2) cast-in-place, (3) shotcrete with rock bolts and mesh, and (4) shotcrete with only mesh. Again, the final choice of support system for initial and final finishing will depend on (a) actual ground conditions, (b) cost, (c) initial support system compatibility, (d) tunnel excavation method, and (d) preference of the tunnel contractor, based on their skill and experience with certain types of systems. 

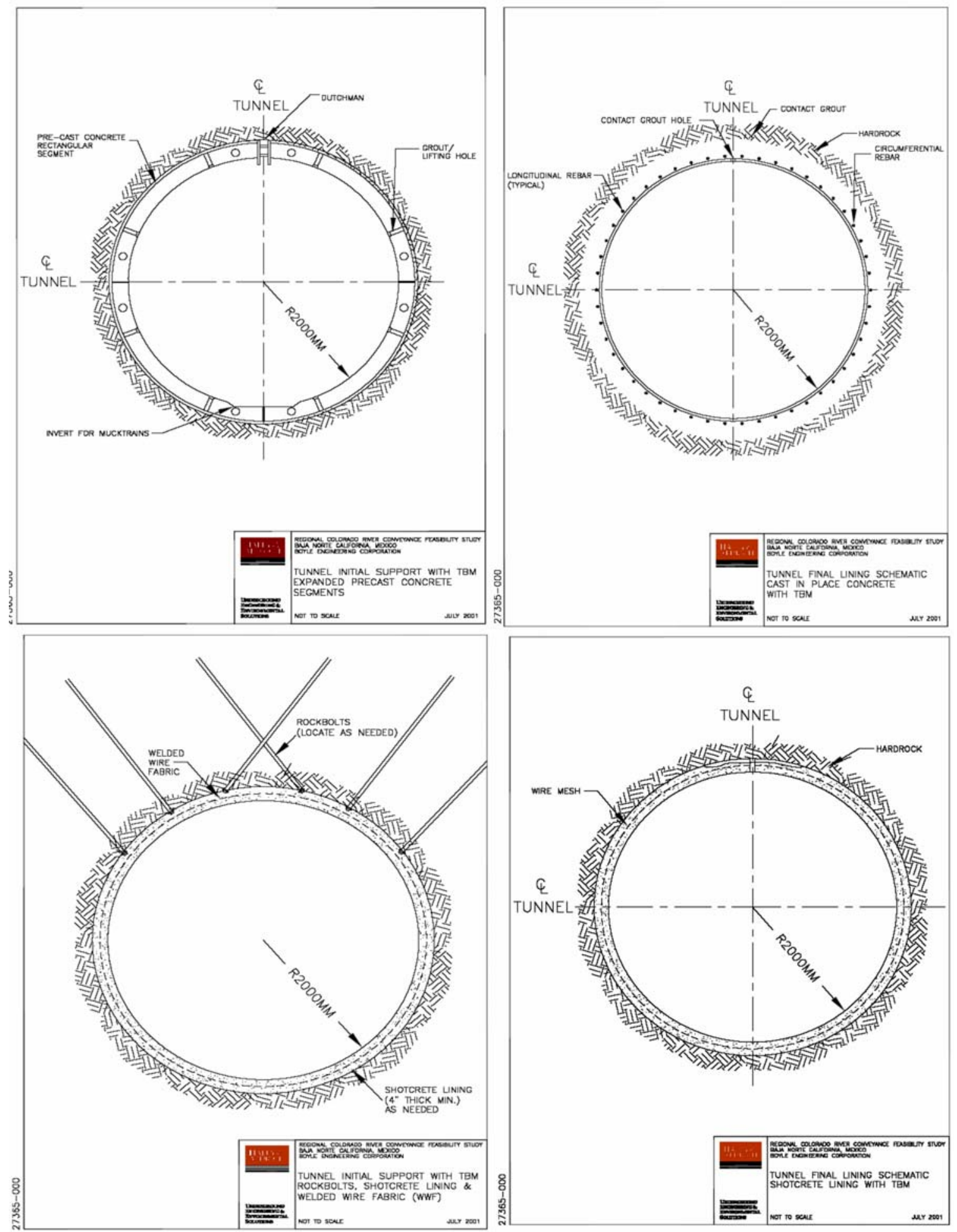

Fig. 16. Examples of applications using high-silica concretes for the finish-liners of YM disposal drifts and connecting tunnels. Top left: precast, top right: cast-in-place, bottom left: shotcrete with rock bolts and mesh, and bottom right: shotcrete with mesh. Source: Boyle. 2002. SD-S241-310-11, "Chapter 9: Tunnel Investigations and Cost Estimates,” Boyle Inc., 7807 Convoy Court, Suite 200, San Diego, California. 


\section{Preliminary Analysis of Potential Cost Savings}

An estimate of the impact of using concrete as a replacement for the current steel repository construction material was performed and a preliminary cost analysis was made to assess the potential savings of using one of the four proposed cement-based technical options to replace the current YMP baseline design for the repository underground construction. The existing baseline design assumes that the a steel lattice on the floor of the repository supports the rail track for WP transport within the repository, as illustrated in Fig. 17. The rails are fastened to this floor lattice with steel stiffener brackets. There are transverse steel support beams spaced at a maximum of $1500 \mathrm{~mm}$ and three longitudinal support beams that parallel the tracks. In addition, there are also two guide beams in this floor system. For ground control, rib-steel sets are crucial supporting components of this tunnel-liner system. The ribs fit the circumference of the tunnel and are spaced about $1000 \mathrm{~mm}$ apart. Behind these ribs, there is a steel mesh to protect the waste canisters from falling rocks.

At least four high-silica, cement-based options can be used to replace the current repository design. These include (1) precast concrete segments, (2) cast-in-place concrete, (3) shotcrete lining, and (4) rock bolts/shotcrete lining with welded wire fabric. These options are illustrated in Fig. 16. The potential future YM tunnel support system may involve full or partial replacement of the current steel-rib system by one or more of these alternatives.

In this preliminary assessment, the option analyzed fully replaces the steel-rib system with a steel fiberreinforced shotcrete (Fig 16). Shotcrete consists of concrete with various admixtures. The additives are mixed with the concrete slurry and pneumatically projected at high velocity onto rock surfaces requiring support. This shotcrete prevents or minimizes rock displacement by filling large open joints and fractures, transferring the rock load to adjacent stable rock, and sealing the rock face to prevent raveling and sloughing. The steel fiber microreinforcement increases the tensile strength of the shotcrete, increasing its fracture toughness by $10-20$ times.

There is an increasing trend in the Canadian mining industry to use shotcrete support systems that are combined with fiber reinforcement. The fiber-reinforced shotcrete offers the flexibility needed to adapt to rapidly changing ground conditions. Shotcrete dry mix, including steel fibers and silica pozzolans, can be

purchased in prepackaged super sacks (sling bags) and conveniently stored at the site until needed. Also if economic, a bulk delivery and storage facility can be built at the site. The dry mix is batched at an on-site plant where the quality of the shotcrete mixture can be controlled before application. Shotcrete can be placed by the dry or wet method.

When steel fiber-reinforced shotcrete are used to line tunnels, costly steel or wood arch forms, and even rebar or mesh, are not required, or at least minimized. Emplacement time is shorter because there is no need for erecting, curing, and removing forms or installing rock bolts with mesh. Shotcrete conforms to the rock surface and smoothes out the irregularities caused by blasting or by a tunnel boring machine. 


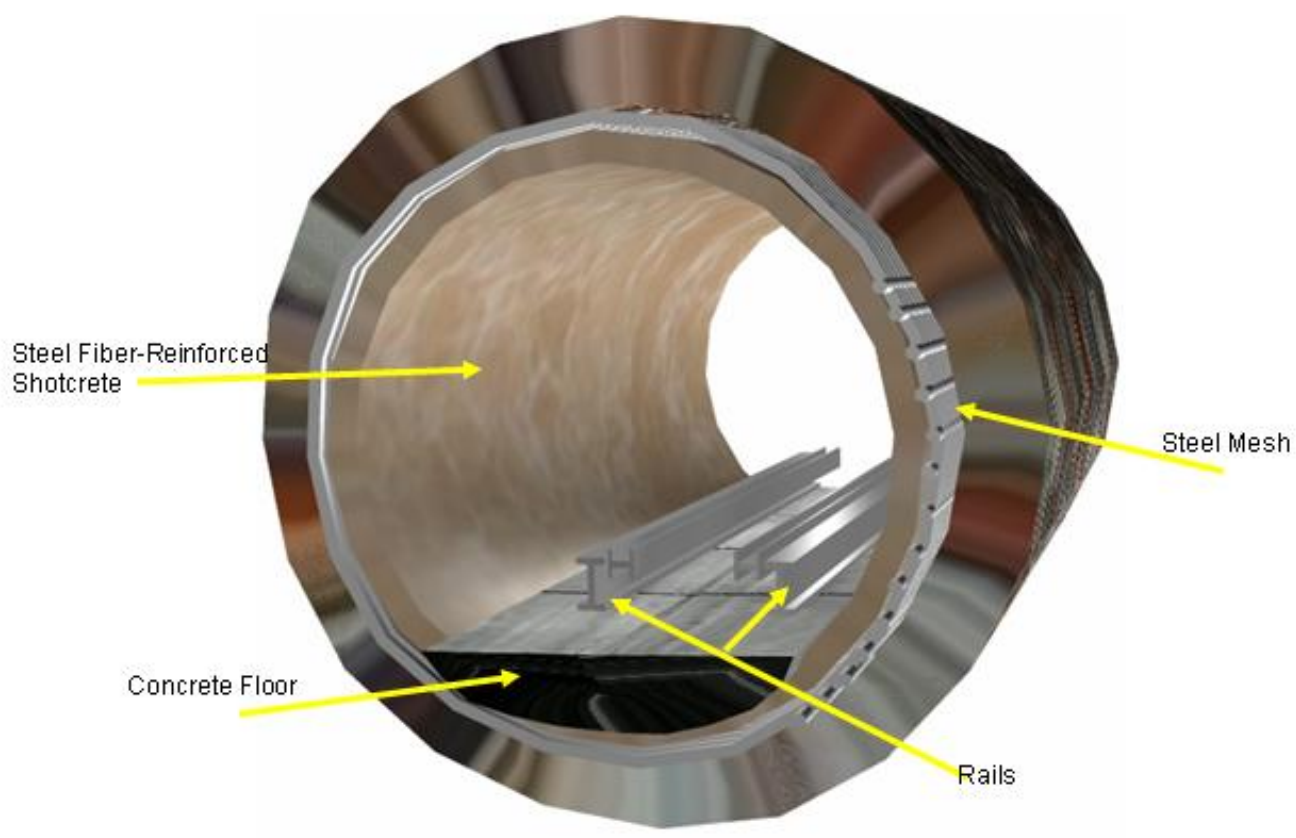

Fig. 17. For the YM repository, this illustrates the proposed application of a fiber-reinforced shotcrete tunnel lining with a high-strength concrete invert, both of which are fabricated using highsilica cements.

In cases where the tunnel rock is locally unstable, the strength of the ground support can be increased to carry the heavier loads by the addition of additional thickness of shotcrete and rock bolts to stop rock movement. Strain monitors may also be embedded in the shotcrete. In zones of very unstable ground, precast, prestressed ring sections made of high-strength silica cements may be installed (see the four options in Fig.16).

This preliminary analysis considered only the case of full replacement of the transverse support beams and the longitudinal support beam by high-silica concrete applied as a shotcrete. Figure 15 illustrates the original baseline invert that is used in the current YMP project's underground-construction cost estimates that is to be replaced by reinforced shotcrete.

The basic assumptions for the system's original design are the following:

- Tunnel diameter: $5.5 \mathrm{~m}$

- Rib separation: $1000 \mathrm{~mm}$

- Rib height: 8 in.

- Rib thickness: 1 in.

- Cost of steel plate : $\$ 0.60 / 1 b$

- Cost of making ribs: $\$ 0.15 / \mathrm{lb}$

Based on these estimates, the cost per kilometer of tunnel is approximately $\$ 1.6 \mathrm{M}$ 


\section{Potential Economic Impacts of Substituting a Conservative 100-mm Thickness of Fiber- Rreinforced Shotcrete}

The basic assumptions for the concrete replacement are

- The system includes bolt and screen attachments

- Steel fiber-reinforced shotcrete cost: $\$ 46 / \mathrm{m}^{2}$

- Thickness of steel fiber-reinforced shotcrete: $100 \mathrm{~mm}$

- Cost of steel plate: $\$ 0.60 / \mathrm{lb}$

- Cost of concrete: $\$ 121 / \mathrm{m}^{3}$

Based on these conservative assumptions, the cost per kilometer of tunnel is approximately $\$ 1 \mathrm{M}$.

\section{Economic Impact of Using a More Likely 50-mm Thickness of Shotcrete}

The basic assumptions for the concrete replacement are

- The system includes bolt and screen attachments

- Steel fiber-reinforced shotcrete cost: $\$ 30 / \mathrm{m}^{2}$

- Thickness of steel fiber-reinforced shotcrete: $100 \mathrm{~mm}$

- Cost of steel plate: $\$ 0.60 / \mathrm{lb}$

- Cost of concrete: $\$ 121 / \mathrm{m}^{3}$

Based on these assumptions, the cost per kilometer of tunnel is approximately $\$ 760 \mathrm{~K}$.

\section{Summary and Comparisons of Preliminary Economic Analyses}

While the actual costs will vary with the support systems required by the local ground conditions, there are generally very substantial savings when the steel invert and the ribs are replaced by a high-silica, concrete-shotcrete support system. From the above assumptions, the savings for a 100-mm thickness of shotcrete tunnel lining are estimated to be approximately $\$ 600 \mathrm{~K}$ per kilometer of tunnel. If a more likely shotcrete lining (50 mm thickness) is used, then the savings could be as much as $\$ 840 \mathrm{~K}$ per kilometer.

So without considering the impacts of an accelerated construction schedule afforded by using a shotcrete liner for the estimated $100 \mathrm{~km}$ of disposal drifts and $30 \mathrm{~km}$ of connecting tunnels, the potential savings to the YMP underground-construction cost ranges from \$78 to \$112M.

\section{The Laboratory Tasks to Support these Objectives}

The following tasks are recommended to meet these needs:

- Selection of local Nevada materials and the formulation of three to four high-silica concrete formulations for per-cast, roller compaction, and shotcrete (with and without fiber reinforcing) applications as required by the YMP design criteria, civil engineering practice, and the American Concrete Institute (ACI) guidelines and ASTM standards.

- Physical testing of aged samples (prisms) of selected formulas at the temperature expected at the YMP repository conditions. Testing should generally comply with ASTM standard methods; however, when Deutsche Industrie Norm (DIN) and Commissariat à l'Energie Atomique (CEA) methods offer better accuracy and precision, these can be substituted, with detailed documentation of the procedures.

- Static and flow-through (dynamic) tests lasting up to 3 years will be used to study interactions of candidate cementitious materials and WP materials with YM groundwater, at $30-160^{\circ} \mathrm{C}$. 
- Investigations of retardation of radionuclide mobility using packed-column and bulk-diffusion studies of the interaction of radionuclide-doped groundwater compositions with crushed and monolithic concrete samples.

- Biodegradation tests using the method described by Rogers et al. (2003).

- During these tests, the chemistry of the solid and liquid phases and the mineralogical changes in the cement should be measured to determine the extent of mineral alterations and formation of corrosion products.

- GFAA, ICP-MS, ICP-AES and IC are the principal tools for monitoring the composition of the groundwater. Quench-pH and unique, high-temperature, long-term $\mathrm{pH}$ monitoring facilities should be used to monitor solution $\mathrm{pH}$ in contact with cements over long time periods. However, the extent of dissolution of the cements is expected to be very small, and in some cases below the limit of detection of these normal analytical methods. Therefore, measuring the concentration of cement constituents in water may require analysis by radiochemical means. For example, ${ }^{90} \mathrm{Sr}$ could substitute for a small part of the calcium content.

- Characterize and detect the phases that form due to interaction with groundwaterpetrographic and SEMPA analyses and nanophase techniques such as SEM and TEM imaging should be employed.

- Isotopically labeled water should be used to allow isotopic and elemental imaging using secondary ion mass spectrometry (SIMS) to track the migration of the fluid into the solid samples at the micro- and nanoscale.

- Cost comparison study of the current practices that use concretes in the build-out of underground tunnels and drifts should be made with the current YMP underground construction baseline to evaluate potential cost reductions.

- Physical-chemical models coupling the transport of water, chloride, and heat have been successfully used to reproduce data observed in in situ exposures (Petre-Lazar et al. 2003). In addition, there are models that allow variable exposures with a thermodynamic analyses that are coupled with moisture transport, cement paste hydration, and microstructure phenomenology (Ishida and Maekawa 2003).

\section{Need 2: Establish Long-Term Performance of High-Silica Concretes by Studying AND Characterizing Natural AND ANTHROPOGENIC ANALOGS IN ORder To Predict the Long-Term Performance (>300,000 YeARS) OF THESE MATERIALS}

Natural, historical, or archaeological materials can be considered good analogs for repository materials performance assessment (Ewing 1979). While their use has been quite limited in the past for the design of matrices, both qualitative and quantitative information of great (and in some cases unique) interest has already been inferred for assessing their long-term performance (Petit 1992B). For example, several historical and archaeological cements (notably Roman and Gallo-Roman cements) have been studied as analogs of cement-based matrices (Rassineaux et al. 1989; Jull and Lees 1990). 
Although most of these materials were made with a technology different from that used currently, similar constituents (hydrated calcium silicates, ettringite, etc.) can be found. Further research must follow accepted guidelines for selecting samples and interpreting results of these tasks (Chapman et al. 1984, Petit 1992A, IAEA 1989).

Therefore to assess the long-term stability of the candidate cementitious materials, additional research is needed to characterize the effects of weathering and alteration of natural and anthropogenic analogs of the cementitious matrices proposed for YM.

Two types of analogs are available for investigating the effects of long-term weathering processes on the stability and strength of silica-rich cements that could be used in the repository construction: Roman cements and sanindinite-facies metamorphic rocks.

\section{Anthropogenic Analog Studies}

Roman pozzolanic cements and sanidinite-facies metacarbonates are chemically and mineralogically very similar to modern high-silica cements, and taken together they allow investigations of the fate of such materials over intervals of thousands, and tens-of-thousands of years. Therefore, pertinent samples should be collected in collaboration with local geologists and archaeologists (see attached letters in Appendix A) who will act as consultants and guides in the collection of samples of both types of analogs, which have been exposed to diverse weathering environments.

Since Roman cements are archaeological artifacts, there are severe restrictions to ensure their preservation in the various countries. Therefore the collection of Roman cements for study as YM analog materials is somewhat more difficult than collection of sanidinite-facies metamorphic rocks. Even though there are limitations on removing samples from their country of origin, most countries allow permits for their export.

Although Portland cements have many advantages over hydraulic limes (Czernin 1962), they also have many disadvantages. One of the most important of these is that OPCs tend to release calcium hydroxide during hydration, which causes weak spots in the hardened paste, an increase in the $\mathrm{pH}$ of surrounding waters, and the formation of efflorescence on surfaces. The addition of reactive Si and Al to the cement (pozzolanic cements), which reacts with the calcium hydroxide to form calcium silicate and calcium aluminate hydrates, can significantly reduce or completely eliminate the release of soluble calcium hydroxide. Therefore, the advantages of pozzolanic cements lie in their reactive Si and Al concentrations.

The properties of pozzolans vary considerably depending on their origin. This is caused not only by variations in the proportions of the active materials, but also of other mineralogical and physical characteristics. In general, however, silica accounts for more than half of the total weight of the pozzolan, the remainder consisting mainly of alumina, ferric oxide, and a few percent of lime and magnesia (Czernin 1962). In some cases, the alkali content can reach $4 \%$.

Although a great deal is known about pozzolanic cements, very few reliable, modern chemical methods have been applied to the problem of quantifying and characterizing the reactivity of these materials during fluid-rock interaction. Major advances in nano-scale imaging [e.g., high-resolution transmission electron microscopy (HRTEM) techniques, NanoSIMS imaging (Capitani et al. 2000)] and micro-analytical techniques [e.g., secondary ion microprobe (SIMS) (McLaren et al. 1994)] permit characterization of alteration within a single mineral grain, and thus the submicroscopic chemical processes in pozzolanic cements can now be studied in great detail.

Preliminary studies have been conducted at Oak Ridge National Laboratory (ORNL) on coupled reactive, diffusive exchange during the alteration of silicate phases such as alkali feldspar by placing grains of 
Amelia albite and Madagascar sanidine in $1 \mathrm{~m}$ and $2 \mathrm{~m} \mathrm{NaCl}$ and $\mathrm{KCl}$ solutions, respectively, with a solvent of composition $\mathrm{HD}^{18} \mathrm{O}_{0.5}{ }^{16} \mathrm{O}_{0.5}$. Samples were heated to $600^{\circ} \mathrm{C}$ at a pressure of $200 \mathrm{MPa}$ for periods of 4-6 days. The resulting exchanged rims were up to $\sim 25 \%$ of the original grain diameter. ORNL's study determined the elemental composition of the feldspar grains by electron microprobe analysis, the width of the rims by scanning X-ray and back-scattered electron images, and the distribution of ${ }^{18} \mathrm{O}, \mathrm{H}$, and D by scanning ion images using secondary ion mass spectrometry (equivalent to ORNL's Cameca $4 \mathrm{f}$ and/or Washington University's Cameca NanoSIMS).

An example of such experimental results is shown in the figures below. Fig. 18a shows a light gray Kfeldspar rim on Amelia albite (scale bar $=50 \mu \mathrm{m}$ ). The rim-core boundary is sharp at the 1-2 $\mu \mathrm{m}$ spatial resolution of the electron probe. The distribution of ${ }^{18} \mathrm{O}$ and ${ }^{16} \mathrm{O}$ in the same grain (from Cameca $4 \mathrm{f}$ SIMS measurements) is shown Fig. 18b. The light gray regions are the ${ }^{18} \mathrm{O}$-rich rims, and the darker gray in the core is the ${ }^{16} \mathrm{O}$-rich region. The pattern of $\mathrm{O}$ isotope distribution matches the cation distribution within spatial resolution of Cameca 4f SIMS. Very high spatial resolution $(\sim 70 \mathrm{~nm})$ NanoSIMS imaging (Washington University) results (Fig. 18c) reveals much greater detail. These experiments and analytical and imaging techniques allow monitoring and quantifying fluid-rock at scales that were previously unachievable.

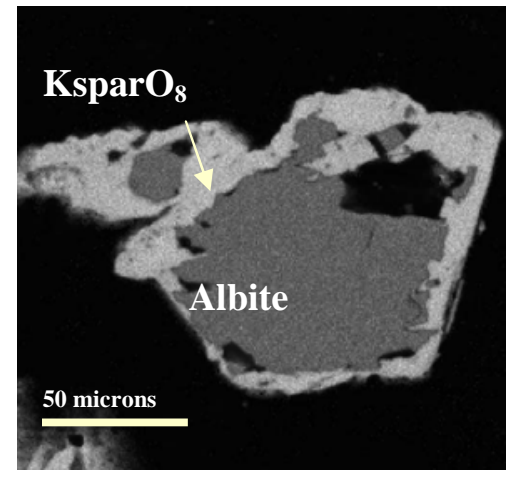

Fig. 18 (a). Electron backscatter image of K-spar replacing albite at $600^{\circ} \mathrm{C}$.

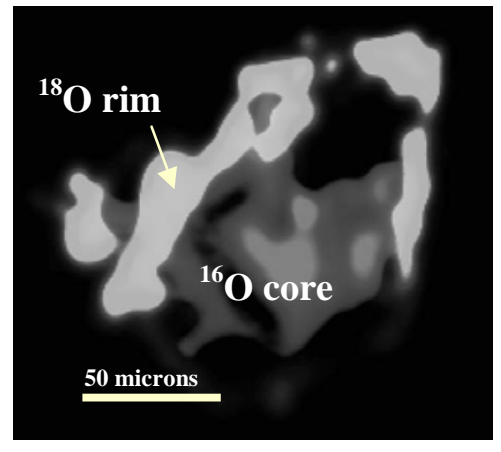

Fig. 18 (b). ${ }^{18} \mathrm{O}$ enriched zones (light) coincident with K-Na exchange.

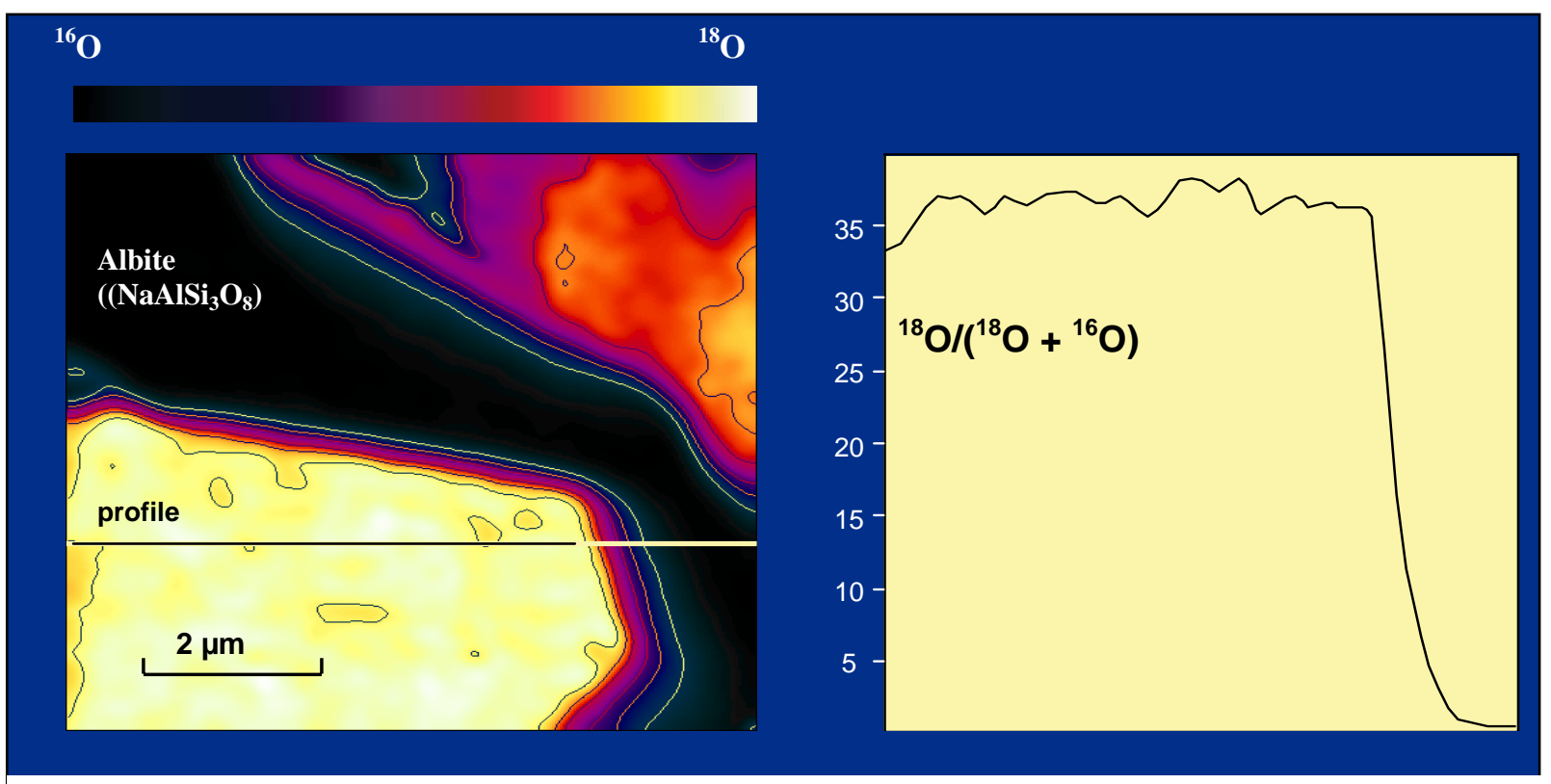

Fig. 18c. NanoSIMS ion imaging (contour map on left; line scan on right) of $O$ isotopes in a reaction zone in which albite reacted with ${ }^{18} \mathrm{O}$-enriched 2 molal $\mathrm{KCl}$ at $600^{\circ} \mathrm{C}, 200 \mathrm{MPa}$ for 6 days. 


\section{Roman Cements}

The strength and durability of Roman cements is legendary. The Pantheon in Rome has stood for over 1,800 years - without steel reinforcement in its cement structure. The famous Trevi fountain in Rome is still fed from the Salone springs, 11 miles outside the city, via the Aqua Virgo, a concrete aqueduct built in the year 19 B.C.E. during the reign of Ceasar Augustus. The arch of Constantine, many parts of the Colosseum or Flavian Amphitheater, the Pons Fabricus, the harbor at Puteoli, Trajan's forum, and many other ancient concrete structures are still standing, having withstood attack by the elements for over 2,000 years. The quality of Roman concrete is so good, in fact, that many engineers suggest that it is as good or better than commonly used modern materials and have sought to learn its "secrets" (Moore 1995).

In deciding whether Roman concrete is, indeed, a good analog for the high-silica concrete proposed for use at Yucca Mountain, it is necessary to first discuss what Roman concrete is (Moore 1995). In his book De Architectura (1st Century B.C.E.), the Roman author and architect Vitruvius states that the magnificent quality of Roman concrete resulted from the extensive use of artificial pozzolanic mortars and concretes. Roman concrete (opus caementicium), like modern concrete, is an artificial building material composed of an aggregate, a binding agent, and water. Aggregate is essentially filler, such as gravel, chunks of stone and rubble, broken bricks, etc. Binding agent is a substance that is mixed with the aggregate wet (water added) and solidifies when it dries, or "sets." Many materials, even mud, can be used as a binding agent, that we generally call mortar.

Historically, lime or gypsum mixed with rubble stones, have been used as strong binding agents. The Roman contribution to this basic structural mixture was the addition of pozzolan-a special volcanic dust found in central Italy - to the binder. Pozzolan created an exceptionally strong bond with the aggregate. In most parts of the Roman world, where similar volcanic powders could not be found, local materials such as lime or gypsum were used. By contrast, the binding agent used in modern concrete is called "cement," or Portland cement. It is manufactured artificially from burned limestone and clay. Modern concrete is stronger than Roman concrete mainly because it incorporates steel bars to build up tensile strength; technically, it is reinforced concrete, or ferro-concrete. The Romans did not use metal-reinforced concrete.

The evolution of Roman concrete began in the Middle East where walls for fortifications and homes were made by pounding moist clay between forms. To protect the surface of the clay from erosion, the ancient builders discovered that a moist coating of thin, white, pasty lime would harden to give their walls significant protection from rain and weather. Heating limestone in a kiln and then quenching the result in water created lime. When the lime plaster dries out, the calcium in the material chemically combines with carbon dioxide in the air to give a hard protecting shield. A precursor to Roman concrete may have been found about 200 B.C.E when one of these lime coatings was applied to a wall made of volcanic, pozzolanic ash near the town of Pozzuoli in Italy. A reaction occurred between the ash (silica and small amounts of alumina and iron oxide) and lime (calcium hydroxide), strengthening the coating. Later they found that mixing powdered volcanic ash with moist lime made a thicker, more durable product that could be submerged in water - something a mixture of lime plaster and plain sand could not match. This reaction occurs because pozzolan contains a significant amount of high surface area amorphous silica that reacts much more quickly with the lime than is possible with crystalline quartz.

Concrete, as the Romans developed it, had definite technical and practical advantages over traditional methods of enclosing space that used cut-stone and post-and-beam structures. These advantages can be summarized as follows: (1) it was exceptionally strong and could span great distances when shaped into arches, vaults, and domes; (2) it had greater flexibility in molding space because concrete was virtually "poured" (or layered) into a formwork and took the shape of its container-concrete is in that sense is a "plastic" material; (3) it did not requite special, skilled labor, therefore, it was cheaper to use; (4) it was much faster to construct than laboriously cut masonry; (5) since concrete-vaulted roofing was fireproof, 
unlike the wooden-beamed roofs of traditional systems, it was safer. From the earliest days of the Republic, Romans took advantage of this method in the construction of foundations, terraces, and harbor structures (because concrete could set under water). It was a formidable tool of Roman engineering.

From the point of view of a modern application of high-silica concrete to YM, study of Roman concrete has a number of distinct advantages. First, it is compositionally very similar to compositions that might be used at YM. While Pozzolana would likely be replaced by fly ash as the source of the reactive high-silica component of the binder, the resulting bulk composition and mineralogy will be quite similar.

Mineralogical examinations of Roman concrete show the presence of stable mineral phases, all of which have been observed in modern high-silica cements (Moore 1995). Second, Roman concrete was widely used in the ancient world. Examples exist not only in Italy, but throughout much of the extent of the ancient empire. In addition, it was not only used subarially, but its ability to harden underwater made it an ideal material for harbor construction. Thus, samples are available that have been exposed to a very wide variety of environmental conditions. Third, the 2000-year exposure time age of Roman concretes is a significant fraction of the 10,000-year required lifetime of the repository, thus reducing extrapolations from laboratory time-scale experiments while still providing a window into the nature of the concrete during the repository's functional period.

\section{Natural Analogs}

The contact metamorphism of calc-silicate rocks is one of the classic studies in metamorphic petrology, dating back to the work of Eskola (1922), Tilley (1923), and Bowen (1940), who established the series of minerals observed with increasing temperature during contact metamorphism of carbonates. Such contact aureoles form over a wide range of temperatures. Low- and intermediate-temperature contact aureoles, such as those at Alta, Utah (Moore and Kerrick 1976), and Black Butte, Montana (Bowman and Essene 1984, Bowman et al. 1985) and aureoles associated with a number of ore deposits, where metamorphic temperatures seldom exceed $600-700^{\circ} \mathrm{C}$ are very common. High temperature sanidinite-facies aureoles, however, are relatively rare. Examples include Crestmore, California (Burnham 1959), the Christmas Mountains aureole, Texas (Joesten 1974, 1976, 1977, 1983; Joesten and Fisher 1988), Marble Canyon, Texas (Bridge 1966a,b, 1980, 1986), the Hatrurim formation, Israel and Scawt Hill, Northern Ireland (Tilley 1929, 1942). It is, however, these latter examples that are of interest as analogs for long-term stability of high-silica cements at YM.

\section{Sanindinite-Facies Metacarbonates}

Sanidinite-facies metacarbonates are formed as the result of high-temperature, low-pressure metamorphism and metasomatism of carbonate rocks. The name is somewhat of a misnomer, as they are typically composed largely of calc-silicate minerals, most of the carbonate having been lost during the metamorphism. It is not, however, the metamorphism that formed sanidinites that is of interest when considering them as potential analogues for high-silica cements at YM, but the processes of alteration and weathering that have occurred since their formation. Therefore, sanidinite-facies metacarbonates are very useful as analogs for high-silica cements at YM for two reasons. First, many of the phases that occur in them are exact analogues of those in high-silica cements. Thus they are chemically, mineralogically, and texturally very close to true natural analog materials. Second, because they have been exposed to weathering for reasonably long periods of time in a variety of environments-much longer than even Roman cements - they can be used to predict how high-silica cements will respond in the repository over the mandated time periods.

While a large number of mineral phases have been found in sanindinite-facies metacarbonates, they are largely composed of calcium silicates. The exact mineralogy varies from location to location, yet these rocks contain assemblages involving rankinite $\left(\mathrm{Ca}_{3} \mathrm{Si}_{2} \mathrm{O}_{7}\right)$, bredigite $\left(\mathrm{Ca}_{7} \mathrm{Mg}\left(\mathrm{SiO}_{4}\right)_{4}\right)$, larnite $\left(\alpha-\mathrm{Ca}_{2} \mathrm{SiO}_{4}\right)$, $\beta-\mathrm{Ca}_{2} \mathrm{SiO}_{4}$, wollastonite $\left(\mathrm{CaSiO}_{3}\right)$, hatrurite $\left(\mathrm{Ca}_{3} \mathrm{SiO}_{5}\right)$, tilleyite $\left(\mathrm{Ca}_{5} \mathrm{Si}_{2} \mathrm{O}_{7}\left(\mathrm{CO}_{3}\right)_{2}\right)$, spurrite $\left(\mathrm{Ca}_{5} \mathrm{Si}_{2} \mathrm{O}_{8} \mathrm{CO}_{3}\right)$ and others. Some also contain calc-magnesium silicates such as monticellite $\left(\mathrm{CaMgSiO}_{4}\right)$, melilites 
$\left(\mathrm{Ca}(\mathrm{Mg}, \mathrm{Al})(\mathrm{Si}, \mathrm{Al})_{2} \mathrm{O}_{7}\right.$ diopside $\left(\mathrm{CaMgSi}_{2} \mathrm{O}_{6}\right)$ and merwinite $\left(\mathrm{Ca}_{3} \mathrm{MgSi}_{2} \mathrm{O}_{8}\right)$. Common alteration phases include tobermorite $\left(\mathrm{Ca}_{5} \mathrm{Si}_{6}(\mathrm{O}, \mathrm{OH})_{18} \cdot 5 \mathrm{H}_{2} \mathrm{O}\right)$, af willite $\mathrm{Ca}_{3} \mathrm{Si}_{2} \mathrm{O}_{4}(\mathrm{OH})_{6}$, foshagite, $\left(\mathrm{Ca}_{4} \mathrm{Si}_{3} \mathrm{O}_{9}(\mathrm{OH})_{2}\right)$, talc, serpentine, and xonotlite $\mathrm{Ca}_{6} \mathrm{Si}_{6} \mathrm{O}_{17}(\mathrm{OH})_{2}$. Geologically unusual phases, such as brownmillerite $\left(\mathrm{Ca}_{2}(\mathrm{Al}, \mathrm{Fe})_{2} \mathrm{O}_{5}\right.$ and mayenite $\left(\mathrm{Ca}_{12} \mathrm{Al}_{14} \mathrm{O}_{33}\right)$ otherwise known only from cement clinker, have also been found.

While the terminology is different, the phases that occur in these rocks are analogous to those in highsilica cements. Classic Portland cement clinker consists of four minerals (before hydration): alite, or $\mathrm{C}_{3} \mathrm{~S}$, which is identical to hatrurite; belite, or $\alpha-\mathrm{C}_{2} \mathrm{~S}$, which is identical to larnite; aluminate, or $\mathrm{C}_{3} \mathrm{~A}$; and ferrite or $\mathrm{Ca}_{4} \mathrm{AF}$, which is identical to brownmillerite. Addition of excess silica as a binder stabilizes silicates relative to calcium hydroxide during hydration, and many of the calcium silicate hydroxides mentioned above as alteration phases in the sanidinite-facies metacarbonates are also well known in high-silica cements.

Although high-temperature sanindinite-facies metacarbonates are not geologically common, several are known. These include localities at Crestmore, California (Eakle 1917; Murdoch 1955, 1961; Burnham 1959), the Christmas Mountains aureole, Texas (Clabaugh, 1953; Joesten 1974, 1976, 1977, 1983; Joesten and Fisher 1988), and Marble Canyon, Texas (Bridge, 1966a,b, 1980, 1986; Anovitz and Kalin 1990; Anovitz et al. 1991, 1992), Scawt Hill, Ireland (Tilley 1929, 1933 1942; Tilley and Harwood 1931), the Hatrurim formation (Mottled Zone, Israel), as part of a xenolith and autolith swarm in the Lower Zone of the Kiglapait Intrusion, Labrador (Owens 2000); the Oslo rift in southern Norway (Goldschmidt 1911; Tracy and Frost 1991; Jamtveit et al. 1997), Mayen in the Laacher See region of Germany (Jasmund and Hentschel 1964), localities in Velardena and Coahuila in Mexico (Wright 1908; Temple and Heinrich 1964), the Little Belt Mountains in Montana (Taylor 1935), the Tres Hermanas Mountains (South Sister Peak) in New Mexico (Homme and Rosenzweig 1958), Carlingford in Northern Ireland (McConnell 1954, 1955, 1960), the Isles of Skye and Much and Rhum in Scotland (Wyatt 1953; Tilley 1947; Hughes 1960), Kilchoan and Ardnamurchan in Scotland (Agrell 1965), Tokatoka, New Zealand (Mason 1957), Lower Tunguska, Siberia (Sobolev 1935; Reverdatto 1964), Mysore State, India (Naidu and Covidarajulu 1954) and the Sinai (Gross 1977).

The following analog study tasks should be performed:

- Collect anthropogenic pozzolanic cement samples with the cooperation of museums and archeologists from Europe and Asia.

- Collect natural samples by field trips and by cooperation with geologists from the United States, Europe, and Asia.

- Examine archeological and natural samples with the techniques that are discussed below and compared to the samples exposed during laboratory studies.

The laboratory and natural analog data should be compared with the prediction of current, selected models for aging cementitious materials. Then, further research should attempt to extrapolate performance and the long-term source term to the YMP risk models 


\section{Need 3: Negotiate and Coordinate Work Plans with Parallel Russian Program under an InTernational Science and Technology Center (ISTC) AGREement WITH the RusSian FEDERATION}

Pursuant to the agreements reached on October 15-24, 2004 in Moscow, Russian Federation (RF), and as described in the ORNL Trip Report 215960, November 9, 2004, U.S. researchers will negotiate scopes, schedules, and support under an International Science and Technology Center (ISTC) initiative for those RF tasks to be performed in coordination with U.S. tasks described below. Four areas of cooperative tasks were negotiated and are described by the following excerpt from ORNL Trip Report 215960.

These delegates reached agreements on four RF tasks that are to be coordinated with the U.S. program to develop and test high-silica cements for use in the YM Repository Project:

1.Develop independently, using local materials, high-silica cements for their storage and repository facilities. Based on these results, they will make recommendations to the United States on improving the durability and performance of high-silica cements for YM.

2. Measure surface alterations and aging of these materials to characterize and quantify interactions of these and U.S. high-silica cements with groundwaters comparable to YM.

3. Characterize the performances of these high-silica cements as "getters" in the retardation of nuclide transport from the YM repository, measuring and quantifying the partitioning and absorption of radionuclides onto and into these cements.

4. Survey, select, combine, modify, code, and apply current models that predict the long-term performances of cements in order to link the RF/U.S. laboratory and analog studies with predictions.

\section{DESCRIPTION OF TASKS}

The following are descriptions of the tasks to be performed to meet the two objectives of (1) developing and testing high-silica cements for the YMP and (2) comparing the results to anthropogenic and natural analogs in order to extrapolate the prediction of their performances to time frames relevant to the YMP.

This experimental program is needed to develop high-silica cements suitable for YM applications. These experiments will specifically address the effects of cement composition and binder type on cement strength and durability, water chemistry, and radionuclide transport and retention. To address these issues, candidate concrete binders should be used that will include pozzolans, trass, blast furnace slags, and other high-silica, hydraulic cements. Static and flow-through (dynamic) tests should be performed to study the interaction between candidate cementitious materials, YM groundwater, and WP materials at temperatures bracketing the expected repository service conditions $\left(30-160^{\circ} \mathrm{C}\right)$. These tests should run up to 2 to 3 years, during this time, the chemistry of the solid and liquid phases and the mineralogical changes in the cement should be periodically monitored to determine mechanisms and kinetics of alterations and formation of corrosion products.

Specifically, researchers should experimentally study the solubility of these cements using a series of experiments to characterize the alteration products, and understand the mechanisms involved during 
element mobility between the solid and the liquid phase. Techniques should be used such as SEM with electron dispersive X-ray (EDX) and secondary ion microscope (SIMS) imaging coupled with highresolution transmission electron microscopy (HRTEM) analysis of the solid phase to characterize the nanotextures that develop during the alteration process. GFAA, IC, ICP-MS, ICP-AES, and pH analysis of the liquid phase should allow monitoring change in the chemistry of the fluid during the alteration process.

\section{Laboratory Studies}

The laboratory studies are needed to select regionally available components and develop high-silica concrete formulations that meet the engineering criteria for specific applications in the YM repository, which include (1) lining of drifts and tunnels, (2) construction of the invert (tunnel floor), and (3) construction of bulkheads and other seals for the disposal drifts and tunnels. The formulations should use mixtures of Portland cement, blast furnace slags, class F fly ashes, and/or silica fumes. Also, local aggregates, such as crushed and graded basalt, should be screened. Metal fiber microreinforcement to increase the fracture-toughness may be used in the shotcrete formulas for tunnel liners. These formulas should be first screened for workability and set properties, then for expansion, compressive and flexstrength, dynamic modulus of elasticity, and Poisson's ratio. Three to four formulas that meet the engineering requirements for their specific applications should be chosen to continue the study, in which they will undergo exposure to YM groundwater and elevated temperatures.

During and after the exposure studies, the test specimens should be tested for strength and examined for surface alterations and compared with natural analogs. The chemical analyses of the leachates should be measured for the major constituents. Some of the exposure tests should include samples of high-fired fuel pellets (depleted uranium) in order to establish the formation of silicates on the surface of the concretes and fuel pellets.

In addition, cured concrete specimens should be submitted for inclusion in the ongoing corrosion studies, such as those at ORNL. Even though sufficient nutrients are not expected to exist in the YM repository horizon that could support biota, some selected specimens should be submitted for testing, using the modified NRC accelerated test for microbial degradation (Rogers et al. 2003).

\section{Selection of Materials and Formulations}

This study should select local Nevada materials and formulate three to four high-silica concretes for precast, roller compaction, and shotcrete (with and without fiber reinforcing) applications as required by the YMP design criteria, civil engineering practice, and the ACI guidelines and ASTM standards. (For example: ASTM C 150 - 02a, ASTM C 595 - 03, ASTM C 618-99, ASTM C 136-01 2001, ASTM C 989 - 04, ACI 21R-96 2001, ACI 211.1-97, ACI 233R-03 2004, and others as appropriate.)

In order to develop concrete formulation/blends it is anticipated that the following raw materials should be used:

- Freshly ground and graded basalt aggregate for the concrete

- Portland cement Type II-V

- Class F fly ash

- Blast furnace slag (BFS)

- Silica fumes

- Superplasticizers (polyols when possible)

The raw materials must be selected from regional sources when they are adequate and available. A complete certified characterization of each material should be performed or obtained from the supplier. The following characteristics should be verified for each of the raw materials: 
- Chemical composition

- Density

- Particle size distribution

- Blaine fineness

- XRD spectrum

After a source of material is selected, based on low sulfur and alkali and high reactive silica contents, a certified and validated batch of each material should be stockpiled in a quantity adequate to supply the program for its duration. Current estimates show that in total about $2,000 \mathrm{~kg}$ ( 2 tonne) of these materials will be required to make all of the required test specimens and to conduct the rheological testing, as well for testing to scale-up of the emplacement applications.

Formulations should be selected that meet the compositional criteria established in Fig. 1. However, when Class F fly ash is used, the silica composition may exceed the upper limit established in Fig. 1 because these have a range of particle sizes, and the larger particles react more slowly. Therefore, this residual unreacted silica has an advantage of supplying a reserve source of silica that is capable of healing microcracks.

The selected formulations must balance the requirements of composition, workability, and final strength. Compositions should be chosen to be consistent with the centuries-old examples of durable cements and concretes.

\section{Preparation of Test Specimens and Physical Testing \\ Fresh Paste}

The tests required to be performed on the fresh paste should characterize the properties of the concrete before hardening. These tests should to be performed at room temperature. These rheological data over the range of processing and emplacement strain-rates are important to predict mixing and workability for the civil engineering applications.

Scoping tests must be performed to find the best proportions of each additive-Type V cement, blast furnace slag, and Class F fly ash — and the amount of water and superplasticizer that would minimize the total quantity of water included in the concrete while keeping a workable material. After the formula is selected, test specimens will be cast.

\section{Time of setting of concrete-ASTM C403, "Standard test method for time of setting of concrete mixtures by penetration resistance"}

A mortar sample is obtained by sieving a representative sample of fresh concrete. The mortar is placed in a container and stored at a specified ambient temperature. At regular time intervals, the resistance of the mortar to penetration by standard needles is measured. From a plot of penetration resistance versus elapsed time, the times of initial and final setting are determined. Since the curing of the concrete will not occur at elevated temperature at the disposal site, only the time of setting at ambient temperature should be measured.

\section{Slump of concrete-ASTM C143, "Standard test method for slump of hydraulic-cement concrete"}

A sample of freshly mixed concrete is placed and compacted by rodding in a mold that is shaped as the frustum of a cone. The mold is raised, and the concrete is allowed sag or subside. The change in vertical distance between the original and slumped position of the center of the top surface of the concrete is measured and reported as the slump of the concrete. This method indicates the consistency of the unhardened concrete that is used in construction. 
Another possible rheological test that could be performed would be to measure the shear stress as a function of the shear rate on a sample of the concrete that would have been sieved to remove the large aggregate (ASTM C172). These rheological data are also very useful in engineering the mixing, pumping, and emplacement of concrete products.

Density of concrete-ASTM C138, "Standard test method for density (unit weight), yield, and air content (gravimetric) of concrete"

This test method covers determination of the density of freshly mixed concrete and gives formulas for calculating the yield, cement content, and air content of the concrete.

\section{Preparation of concrete specimens for testing}

The selected formulas should be used to prepare the test specimens for physical testing, chemical exposure, and mineralogical examination. These test specimens shall have a size that is greater than three times the diameter of the largest aggregate contained in the test mixture.

Compressive strength samples on a 2-in. diameter by 4-in. length cylinder

For each time interval $(1,3,6,12,18,24$, and 36 months) three samples are necessary.

The total number of specimens to prepare for this test will be

3 (cylinders) $\times 7$ (time intervals) $\times 3$ (temperatures $)=63$ cylinders

Permeability on 2 in.-diameter by 4 in.-length cylinders

Cured specimens should be tested for permeability at three selected time intervals, 6, 18, and 36 months. The number of specimen to prepare for this test will be

3 (cylinders) $\times 3$ (time intervals) $\times 3$ (temperatures $)=27$ cylinders

Flexural strength on 3 in. $\times 3$ in. $\times 10$ in. prismatic samples

Cured specimens should be tested for flexural strength at three selected time intervals, 6,18 , and 36 months. The number of specimen to prepare for this test will be

$$
3 \text { (prisms) } \times 3 \text { (time intervals) } \times 3 \text { (temperatures) }=27 \text { prisms }
$$

\section{Change in length 3 in. $\times 3$ in. $\times 10$ in. prismatic samples}

At each time interval these prisms should be measured for length and for Young modulus. The number of specimens to prepare for this test will be

$$
6(\text { prisms }) \times 3(\text { temperatures })=18 \text { prism }
$$

Making concrete test specimens to standards-ASTM C192, "Standard practice for making and curing concrete test specimens in the laboratory"

This practice provides standardized requirements for preparation of materials, mixing concrete, and making and curing concrete test specimens under laboratory conditions. The fresh concrete should be tested to evaluate its properties and after a formulation is found having the desired properties, cylinder specimens should be prepared for compressive strength measurements, and prismatic specimens will be prepared for length change measurements. The test cylinders may be of various sizes with a minimum of 2 in. diameter by 4 in. length.

Considering the highest curing temperatures that are selected, 90 and $160^{\circ} \mathrm{C}$, the size of the cylinders should have to fit with the curing device used. It is possible that custom-made containers may have to be manufactured for curing the samples. 
The upper bound on the aggregate size distribution $(<0.375 \mathrm{in} ., 9.5 \mathrm{~mm})$ may be adjusted for very small test specimens ( $<2$ in., $50 \mathrm{~mm}$ ) in order to ensure adequate precision in the physical measurement, so that comparisons between formulations and exposures are meaningful. This will be necessary because as the larger-size fractions of the aggregates become a significant fraction of the test specimens' cross-sections, small imperfections in the samples' preparation are amplified, and the resulting scatter can obscure the effects of incipient physical changes in the matrices.

\section{Curing of specimens}

After curing for the selected time intervals under humid conditions, the concrete samples should be tested for the following mechanical properties. To avoid fluctuations in the results that could be caused by a difference of temperature of the samples, the tests must be performed after the samples have been equilibrated at room temperature.

Prior to being brought to the selected testing temperatures, all the samples generated should undergo a precuring stage that will allow the specimens to hydrate under normal conditions before testing. This precuring period may be as long as 60 or 90 days at room temperature. This length of time is necessary to allow some cement additives (fly ash and blast furnace slag mainly) to start reacting.

\section{Bleeding of concrete-ASTM C232, "Standard test methods for bleeding of concrete"}

This test method covers the determination of the relative quantity of mixing water that will bleed from a sample of freshly mixed concrete. This test should be performed only at ambient temperature. Any significant quantities of bleed water collected should be analyzed for major elemental composition, $\mathrm{pH}$, and alkalinity using appropriate small-sample techniques.

\section{Compressive strength of concrete specimens-ASTM C39, "Standard test method for compressed strength of cylindrical concrete specimens"}

This test method consists of applying a compressive axial load to molded cylinders at a rate within a prescribed range until failure occurs. The compressive strength of the specimen is calculated by dividing the maximum load attained during the test by the cross-sectional area of the specimen. Three specimens should be tested for each time interval and temperature.

\section{Expansion of concrete prisms-ASTM C157, "Standard test method for length change of hardened hydraulic-cement mortar and concrete"}

The measurement of length change permits assessment of the potential for volumetric expansion or contraction of concrete due to various causes other than applied force or temperature change. It is very useful for comparative evaluation of this potential in different concrete mixtures. Six prismatic samples should be used for this test. The same prisms are tested at each time interval. The weight of each prisms should be recorded to follow the evolution of weight with curing time.

\section{Dynamic modulus of elasticity-ASTM C215, "Standard test method for fundamental transverse, longitudinal, and torsional resonant frequencies of concrete specimens"}

This test method is intended primarily for detecting significant changes in the dynamic modulus of elasticity of laboratory specimens that are undergoing exposing to weathering or other influences potentially causing deterioration. The same prisms used for the length change could be tested at each time interval.

\section{Flexural strength of concrete-ASTM C78 "Standard test method for flexural strength of concrete (using simple beam with third-point loading)"}

This test method is used to determine the flexural strength of specimens. Results are calculated and reported as the modulus of rupture. The strength determined should vary where there are differences in specimen size, preparation, moisture conditions, curing, or where the beam has been molded or sawed to 
size. This test should be performed only at the last time interval on the prisms that were tested for length change.

\section{Permeability of concrete-ASTM D5084, "Standard test method for measurement of hydraulic conductivity of saturated porous materials using a flexible wall permeameter"}

This test method applies for one-dimensional, laminar flow of water within porous materials. Concrete specimens are usually very impervious, and it is often necessary to modify this method and use an inert gas such as helium instead of water to obtain data. A few samples could be tested for this parameter.

\section{Additional equipment needed}

Because of the scope and duration of these experiments, additional dedicated equipment may be required to accommodate the large number, large sizes, and test durations. This equipment may include:

- Vacuum oven to dry the samples for porosity and SEM

- Upgrade of the compressive test instrument available to automate it and allow flexural test

- Dynamic modulus instrument

- Large ovens for long-term exposures

- Special containers for curing concrete to accommodate a large number of large test specimens

- Molds

All analytical instruments needed for these tests should be currently available to perform all phases of the proposed research.

\section{Exposure Testing Using Intact Cement Monoliths}

Static and flow-through (dynamic) tests should be performed to study the interaction between candidate cementitious materials, YM groundwater, and WP materials at temperatures bracketing the expected repository service conditions $\left(30-160^{\circ} \mathrm{C}\right)$. These tests should run up to $2-3$ years, during which the chemistry of the solid and liquid phases and the mineralogical changes in the cement should be periodically monitored to determine mechanisms and kinetics of alterations and formation of corrosion products.

The testing program should be based on the following conditions:

- Three testing temperatures: 30,90 , and $160^{\circ} \mathrm{C}$

- The contact solution for the concrete samples is a composite of J13 and UZ

- Concrete specimen should be tested at the following time intervals: 1, 3, 6, 12, 18, 24, 36 months

- Three or four different blends/mixtures will be prepared and studied:

- Low-water, high-strength for precast, vibratory, and/or roller compaction $(>6,000$ psi)

- Regular pumpable concrete mix for standard forms emplacement practices $(\sim 5,000$ psi)

- Shotcrete-reinforced with metal fibers (high fracture toughness)

These different blends should probably contain the same additives but in different proportions, depending upon the application for which they are tailored. 
At each time interval, three cylinders should be tested for compressive strength. The length change can be monitored with six prisms. The same prisms will be used for the measurement of the dynamic modulus of elasticity and Poisson's ratio. The prisms should also be used at the end of the project for flexural strength determination.

For each blend/mixture the following will be needed:

3 temperatures $\times 7$ time intervals $\times 3$ cylinders $=63$ cylinders

3 temperatures $\times 7$ prisms $=21$ prisms

7 cylinders for permeability

Table 5 compares the composite YM solution to be used in this study with the J13 well and UZ groundwaters. With the exception of the silica, the highest levels were chosen for each of the ions in order to be conservative. However, the lower silica concentration was chosen so that synthetic leachant would be more aggressive with regard to dissolving the hydrosilicate matrices from in the cements. A comparison of the composite solution with solutions currently considered most likely to enter the drifts during the hightemperature portion of the repository lifetime (YMP Technical Basis Document No. 5: In-Drift Chemical Environment, Revision 1, November, 2003, Table G-1, Bins 9 and 11) indicates that the proposed composite solution is significantly higher in $\mathrm{Ca}^{2+}$ and $\mathrm{Mg}^{2+}$ and lower in silica and $\mathrm{F}^{-}$. The final composition may be adjusted slightly to balance the cation and anions.
Table 5. The composite YM solution to be used in this study compared with the $\mathrm{J13}$ well and unsaturated zone (UZ) groundwaters

\begin{tabular}{lcccc}
\hline Ion & $\begin{array}{c}\text { Composite } \\
(\mathbf{p p m})\end{array}$ & $\begin{array}{c}\text { Solute } \\
(\text { Mole } \\
\text { fractions })\end{array}$ & $\begin{array}{c}\text { Well J13 } \\
(\mathbf{p p m})\end{array}$ & $\begin{array}{c}\mathbf{U Z}^{a} \\
\text { water } \\
(\mathbf{p p m})\end{array}$ \\
\hline $\mathrm{Cl}^{-}$ & 77 & 0.214 & 7.14 & 77 \\
$\mathrm{NO}_{3}^{-}$ & 12 & 0.019 & 8.78 & 12 \\
$\mathrm{Na}^{+}$ & 45.8 & 0.196 & 45.8 & 9 \\
$\mathrm{~K}^{+}$ & 5.04 & 0.013 & 5.04 & 0.01 \\
$\mathrm{HCO}_{3}^{-}$ & 128.9 & 0.208 & 128.9 & 66 \\
$\mathrm{SO}_{4}^{-2}$ & 79 & 0.081 & 18.4 & 79 \\
$\left(\mathrm{HO}_{2} \mathrm{SiO}_{2}^{-2}\right.$ & 46 & 0.048 & 61 & 46 \\
$\mathrm{Ca}^{+2}$ & 65 & 0.160 & 13 & 65 \\
$\mathrm{Mg}^{+2}$ & 12 & 0.049 & 2.01 & 12 \\
$\mathrm{~F}^{-}$ & 2.18 & 0.011 & 2.18 & 0 \\
\hline
\end{tabular}

${ }^{a}$ Source: Rosenberg, N. D.; G. E. Gdowski; and K .G. Knauss. 2001. "Evaporative Chemical Evolution of Natural Waters at Yucca Mountain, Nevada." Applied Geochemistry 16, pp. 1231-1240.

In order to ensure the initial stability of the carbonate and silica species in this synthetic groundwater, stability testing should be performed for a few weeks. If necessary, the $\mathrm{pH}$ of the composite solution should be adjusted to stabilize the carbonate and silica species. This may also result in starting the exposures with a more aggressive leachant that will test the $\mathrm{pH}$ buffering capacity of the high-silica cements. In exposure tests, the composition of this synthetic groundwater will begin to change immediately as it interacts with the surface phases of the high-silica cements and will continue to change as reactions with the encapsulated aggregate contributes to the aqueous system.

The components of the cement matrix will leach at different rates, and the composition of the leachates will go through a sequence of redepositions of these components back onto the cement surface. This sequence of reactions should be studied by analyzing both the leachate solutions and the secondary minerals that will form on the high-silicate cement surfaces. 


\section{Static exposure testing}

Synthetic groundwater and a large number of test specimens should be sealed separately in Teflon-lined pressure-vessels and allowed to equilibrate. At intervals, the vessels should be cooled, disassembled, and their contents examined and tested.

\section{Curing of the concrete specimens}

Before starting the static test, the specimens should be allowed to cure for 90 days in a solution of saturated humid air.

At the end of the pre-curing, the samples should be transferred into containers suitable for the temperature studied and put in contact with the synthetic groundwater. It is anticipated that three specimens would cure in the same container. This should allow analysis at the selected time interval of the solution corresponding to the concrete samples used for the test. On that basis, for each temperature studied, there will be ten containers necessary for curing the 2 in. $\times 4$ in. cylinders and five containers for curing the 3 in. $\times 3$ in. $\times 10$ in. prisms.

\section{Static test at ambient temperature}

To avoid any reaction with the containers during the test, the concrete specimens should be stored in Teflon containers containing the synthetic YM groundwater. At the selected time interval, the samples should be removed from the containers for testing. The solution should be tested for $\mathrm{pH}$ and chemical composition and the concrete specimen from the compression test should be collected and analyzed for porosity, chemical composition, X-ray diffraction, and SEM observation.

\section{Static test at $90^{\circ} \mathrm{C}$}

For this temperature, the concrete specimen should be cured in Teflon containers stored in an oven at $90^{\circ} \mathrm{C}$. As for samples at ambient temperature, selected samples at $90^{\circ} \mathrm{C}$ of both the solution and concrete specimens should be tested and analyzed.

\section{Static test at $160^{\circ} \mathrm{C}$}

This test should be conducted in commercially available pressure vessels in an air oven. The vapor pressure at this temperature is only six atmospheres, so thin-walled, Teflon-lined vessels can be used. These vessels should be fitted with titanium sampling capillary lines and valves which should allow periodic sampling of the solutions without removal from the oven.

\section{Static test of concrete exposed to YM groundwater and uranium}

The interaction of the concrete with the groundwater loaded with uranium should be studied at the three temperatures. The pre-cured concrete samples must be crushed to accelerate the rate of interaction, and small specimens of the cements should be placed in a container with the synthetic YM groundwater doped with a know amount of uranium. The containers should be kept in ovens at 90 and $160^{\circ} \mathrm{C}$. At selected time intervals, one container can be removed. The $\mathrm{pH}$ of the solution should be measured and the chemical composition of the groundwater will be analyzed. The amount of uranium left in the solution will indicate how much uranium was fixed in cement matrix.

$$
3 \text { temperatures } \times 7 \text { time intervals } \times 2 \text { duplicates }=42 \text { tests }
$$




\section{Mineralogical evaluation}

In addition to the mechanical data obtained, concrete specimens should be examined to identify alteration products that were formed during curing, aging, and exposures. The following evaluation should be performed:

- Mineralogy of the cement paste by X-ray diffraction

- Elemental analysis/composition of the paste by GFAA, IC, ICP-MS, and ICP-AES

- Porosity (if possible because of the aggregates)

- SEM-EDX for selected samples

- Detailed characterization of the alteration products formed on and near the surfaces of the exposed specimens

The exposure tests (described below) will study the solubility and rates of dissolution of high-silica cement phases using a series of experiments to characterize the alteration products, and understand the mechanisms involved during element mobility between the solid and the liquid phase. Techniques should be employed such as secondary ion microscope (SIMS) imaging coupled with HRTEM analysis of the solid phase to characterize the nanotextures that develop during the alteration process. ICP-MS, ICP-AES, and $\mathrm{pH}$ analysis of the liquid phase will allow monitoring changes in chemistry of the fluid during the alteration process.

Focusing on conditions and synthetic groundwater that are expected in the Yucca Mountain radioactive waste repository, the results from these experiments will (1) verify that the compositions of selected pozzolanic cements are stable in subsurface condition similar to the Yucca Mountain repository, (2) show the mechanisms associated with element mobility during alteration and the rates of the alteration of pozzolanic cements, (3) assess the effectiveness of pozzolanic cements to retard radionuclide migration, and (4) measure the effects of organic acids on pozzolan cement reactivity.

\section{Solubility and reactivity of pozzolanic cements}

To determine the near surface environmental effect on pozzolanic cements, a systematic study should be done of the solubility and reactivity of pozzolanic cement phases over a range of groundwater compositions under conditions that are expected in the YM repository.

Experiments should be designed to simulate concrete-tuff contact-environment pertinent to the Yucca Mountain nuclear-waste repository (i.e., groundwater composition, low temperature $\left(\sim 30^{\circ} \mathrm{C}-160^{\circ} \mathrm{C}\right)$ and pressures (vapor pressure)).

Because the expected reaction rates are very slow at these low temperatures and pressures, pozzolanic materials and isotopically labeled (e.g., ${ }^{18} \mathrm{O}$-rich, D-rich, ${ }^{30} \mathrm{Si}$ ) artificial groundwater should be placed in Teflon-sleeved metal vessels, which should then be kept at temperature and pressure in an autoclave. Solids and fluids should be periodically sampled. The solid phases should be examined both at the microscale and nanoscale using back-scattered electron, SEM-EDX, and TEM imaging techniques as well as ion imaging using the SIMS. The fluid should be analyzed using ICP-MS to monitor a variety of elements such as ${ }^{18} \mathrm{O}, \mathrm{D}, \mathrm{Si}, \mathrm{pH}$.

This approach should allow the detection of the progress of slow surficial interactions in real laboratory time, and allow comparison of these results with the examinations of archaeological and natural samples.

\section{Radionuclide migration}

To establish the effect of high-silica cement on the migration of radionuclides, a series of experiments, similar to those described above should be conducted using leachates containing ${ }^{238} \mathrm{U}$. SEM-EDX, SIMS ion imaging, and HRTEM can be used to periodically monitor surface products and the migration of ${ }^{238} \mathrm{U}$ 
into the concrete matrices. The uranium concentration in the fluid as well as other physiochemical parameters such as $\mathrm{pH}$ should be monitored. This approach should allow the determination of the fate of uranium during rock-groundwater-concrete interactions, and provide information on the mechanisms, extent, and rates of element immobilization during the alteration of pozzolanic cements. Ultimately, the migration of ${ }^{237} \mathrm{~Np}$ should also be studied.

\section{Organic ligand impacts on high-silica cement stability}

Researchers should also study the effect of natural organic and inorganic ligand concentrations on pozzolanic cement stability. Isotopically labeled acetate-rich and oxalic-rich fluids should be used. Experimental setup and design can be similar to that described above, and conditions $(\mathrm{P}, \mathrm{T})$ will be pertinent to nuclear-waste disposal (i.e., groundwater, low temperature $\left(\sim 90^{\circ} \mathrm{C}\right)$ and pressures (vapor pressure). The exposed solids and fluids should be sampled periodically and examined as discussed above.

Although there are studies that have examined the influence of inorganic ligands on the solubility of silicate and phosphate phases (Saxena 1966, Kraynov 1969, Giere 1989, Rubin et al. 1993, Fayek and Kyser 1997, Cherniak 2000, Poitrasson et al. 2000, Cherniak and Watson 2001, Trocellier and Delmas 2001, Geisler et al. 2002, Nagy et al. 2002), few studies have considered the influence of organic ligands. Organic ligands have been shown to occur in subsurface fluids (e.g., Carothers and Kharaka 1978, Giordano and Kharaka 1994, Fein 1994) and, they can enhance porosity in sedimentary basins by dissolution of silicate minerals such as feldpars (Fein 1994).

\section{Flow-Through Exposure Testing}

\section{Low-temperature flow-through tests}

Flow-through (or column) experiments should be performed to study the interaction between YM groundwater and both candidate cementitious materials and WP materials (mainly $\mathrm{UO}_{2}$ ) at temperatures in the range $30-90^{\circ} \mathrm{C}$. The flow-through experiment can be conducted in the apparatus such as that shown in Fig. 19, consisting of a column containing a bed of the pozzolanic cement of variable particle sizes or pieces of $\mathrm{UO}_{2}$. The column is approximately $1 \mathrm{~m}$ long and $\sim 5 \mathrm{~cm}$ ID. The bottom support for the specimen bed is fitted with filter paper to catch particulates that may originate in the bed. Surrogate YM water is circulated through the bed in one of two modes: the complete-fill mode, in which the bed is saturated with water at all times; or the drip mode, in which the bed is unsaturated. The

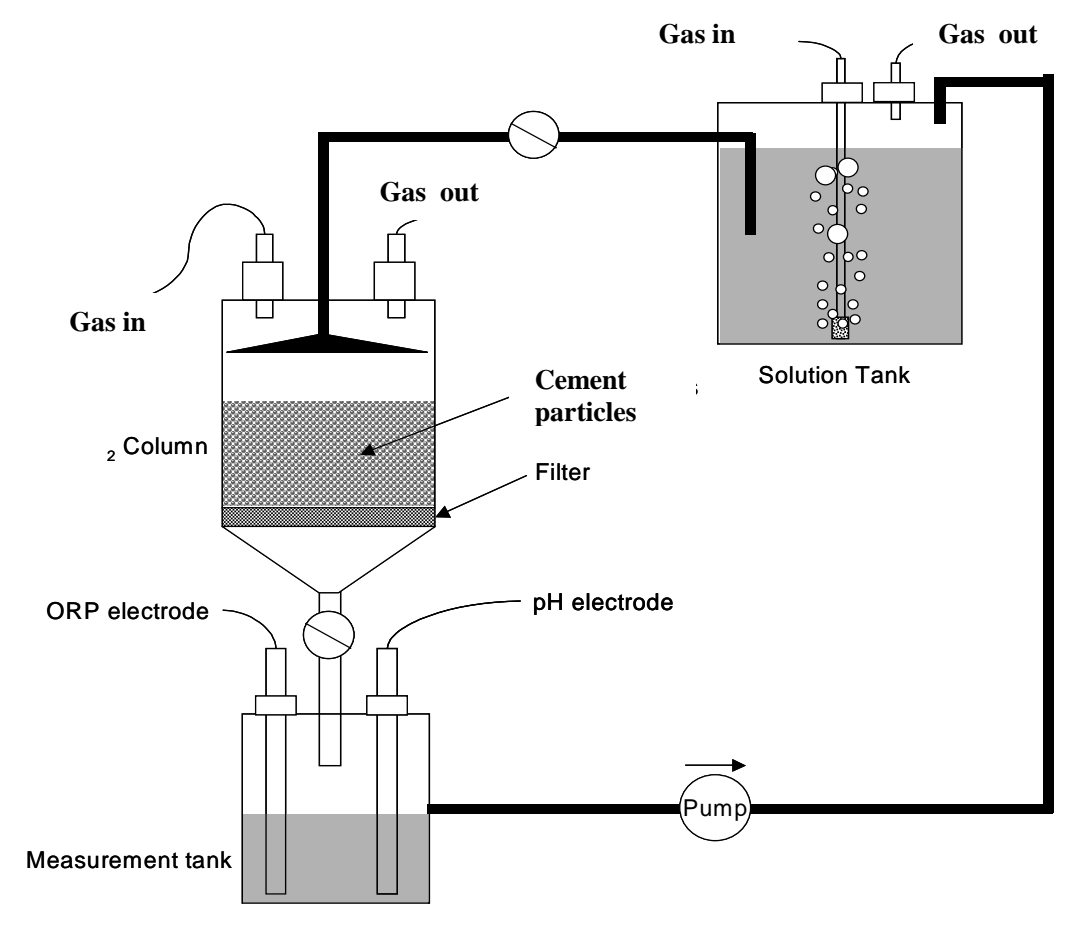

Fig. 19. Cement and WP test apparatus. 
latter condition best simulates conditions at YM but may be more difficult to obtain kinetic data from.

The effluent from the column drains into a measurement tank where various probes measure the oxidation-reduction potential (ORP), the $\mathrm{pH}$, and the $\mathrm{O}_{2}$ content of the exit water. Because the extent of dissolution of the solids in the bed is very small, the water should be circulated through the loop for extended periods of time in order to build up measurable concentrations of dissolved species (or solids on the filter). For this purpose, a small pump returns the water to the solution tank.

The function of the solution tank is twofold. First, it saturates the water with gases. Because the cements and WPs are located in the UZ of YM, the water is exposed to $\mathrm{O}_{2}$ and $\mathrm{CO}_{2}$ in the air, even at the elevation of the drifts. Either or both of these two gases can be sparged into the solution to maintain saturation concentrations in the circulating water. Second, this tank will have a sampling port (not shown in Fig. 19), through which water samples can be periodically removed and make-up water added. The samples should be analysed by GFAA, IC, ICP-MS and ICP-AEC analysis for the major constituents of the solid in the bed: calcium and silicon for a cement bed or uranium for a $\mathrm{UO}_{2}$ bed.

All components of the flow-through column apparatus must be provided with heaters and thermometers to permit experimentation at temperatures up to $\sim 90^{\circ} \mathrm{C}$. All-glass apparatus must not be operated at higher temperatures and pressures than atmospheric pressure.

The experiments are intended to provide experimental data on the kinetics of the dissolution and/or disintegration of cements and $\mathrm{UO}_{2}$ under conditions expected in the YM repository. If run long enough, the recirculating solution may reach the saturation concentration of the principal species in the solid.

Following each experiment, optical microscopy and SEM should be used to examine particles of the bed for alteration products on the surface and any liquid penetration of the porosity in the solid.

\section{High-temperature flow-cell studies}

Researchers should have a history of extensive research experience in the use of high-pressure, hightemperature, chemically inert reaction systems for studies of the solubility of highly insoluble minerals, for example such as Palmer et al. (2002), Bénézeth et al. (2002), and Palmer et al. (2004). Examples of such systems are described in detail by Palmer et al. (2002) and Bénézeth et al. (2002). The system must have all wetted parts composed of titanium, gold, platinum, and polyetheretherketone, so as to ensure chemical nonreactivity of the vessel materials. The system should also include provision for injection of strong base solutions $(\mathrm{NaOH})$ into the output stream, downstream from the reaction zone, but still within the high-temperature, high-pressure portion of the circulation system, in order to prevent plugging of capillary tubing and valves by precipitating silica and other species.

Samples of up to four different cement formulations must be crushed and sized, then characterized for mineralogical and textural properties. The methods will include SEM, XRD, optical thin section examination, and trace element determinations using SIMS, EPM, and other techniques. One of these samples should then be loaded into the high- temperature and pressure flow system, and a series of reaction studies conducted at temperatures of $50,100,125$, and $165^{\circ} \mathrm{C}$.

The chemical compositions of input solutions must also be established. Candidate brines in the system $\mathrm{Ca}^{2+}-\mathrm{Mg}^{2+}-\mathrm{Na}^{+}-\mathrm{K}^{+}-\mathrm{Al}^{3+}-\mathrm{Si}^{4+}-\mathrm{Cl}^{-}-\mathrm{NO}_{3}{ }^{-}, \mathrm{F}^{-}-\mathrm{SO}_{4}{ }^{2-}$ include those identified in YMP Technical Basis Document No. 5: In-Drift Chemical Environment, Revision 1 (November 2003), Appendix G, Table G-3, as being those most likely to enter the drift environment from the geological formation during the hightemperature portion of the repository performance period. In particular, solution compositions in Bins 9 and 11 solutions are considered the most likely compositions to drip onto canister surfaces during the period at which the drift environment is at or above $100^{\circ} \mathrm{C}$. A "deliquescent brine" composition should 
also be tested, and the composition of this solution will be established by consultation with other members of the OCRWM S\&T project research group and program managers. Researchers should test three solution compositions and remove some solid material from the upstream and downstream ends of the packed-column, flow-through reactor for textural and mineralogical studies at the end of each experiment. At the highest temperature, a polished coupon of alloy C-22 should be placed at the outlet end of the reaction cell, and it will be subsequently examined for corrosion-product formation.

Temperature should be ramped from 50 to $175^{\circ} \mathrm{C}$, and samples should be taken periodically over a 2 -week period at each temperature. The major- and trace-element compositions of the brines can be determined using ICP-AES, graphite furnace AA, ion chromatograph, and ICP-MS equipment, and compared with those of the input solution. This matrix represents four temperatures and three solutions for each two-week experiment.

The experimental matrix described above should be repeated during the second year with two new cement formulations, followed by a fourth cement formulation. Follow-up investigations related to these findings may also be necessary.

\section{Hydrogen electrode concentration cell (HECC) studies}

Extensive experience with high-temperature, in situ $\mathrm{pH}$ measurement during heterogeneous studies of mineral solubility, dissolution/precipitation rate studies, mineral surface charge, and ion adsorption studies is required, such as Bénézeth et al. (1999) and Palmer et al. (2001). Also, researchers should have experience with using hydrogen electrode concentration cell (HECC) systems, which are described in detail by Palmer et al. (2001). Such systems should be suitable for acidic, near-neutral, and basic aqueous solutions at temperatures in the range of $0-300^{\circ} \mathrm{C}$. The experimental apparatus must be capable of highly accurate and continuous $\mathrm{pH}$ monitoring experiments can be conducted for periods up to 2 months, permitting long-term studies of the $\mathrm{pH}$ generated by the reaction of cement formulations with the brines described above, and additional solution compositions spanning the range of possible "natural" and "deliquescent" brine compositions that might possibly enter the drift environment during the hightemperature portion of the performance period.

Also, studies of the same four cement formulations mentioned above should be planned for up to 1-month duration, during which the temperature should be ramped from 100 to 125 to 150 and then $175^{\circ} \mathrm{C}$. The $\mathrm{pH}$ generated by each cement formulation must be monitored until a stable or slowly changing $\mathrm{pH}$ is established at each temperature in the various brine compositions tested. For several brine compositions and at each temperature, the $\mathrm{pH}$-buffering capacity and response time to sudden changes in $\mathrm{pH}$ by injection of acidic or basic titrants will be determined. The effect of sudden additions of highly concentrated solutions on $\mathrm{pH}$ and the subsequent chemical evolution of the brines should be tested. During many of these experiments, polished coupons of alloy C-22 will be mounted within the experimental solution. Subsequent to each experiment, the cement will be examined for mineralogical and textural changes, as well as the formation of new mineral phases. The coupons should be examined optically and by SIMS to determine the chemical composition, spatial distribution, and depth of corrosion products; and the surfaces should be scanned for pit formation. These experiments should run continuously for the entire 30-month period.

Researchers should also conduct scoping $\mathrm{pH}$ titrations of the different cement suspensions in the presence of surrogate cations $\left(\mathrm{Ni}^{2+}\right.$ and $\left.\mathrm{Nd}^{3+}\right)$ over temperature range of 100 to $175^{\circ} \mathrm{C}$ to gauge the adsorption of cations on the surfaces of the cement particles (Machesky et al. 1994, Wesolowski et al. 2000, Ridley et al. 2004). Depending on the results of these tests, researchers should determine whether further investigations are necessary and correlate these findings with results of the static adsorption experiments with $\mathrm{U}(\mathrm{VI})$ solutions. 


\section{Radionuclide migration and encapsulation experiments}

Researchers should conduct experiments determining the migration of radionuclides in different highsilica concretes. These experiments should be conducted in parallel to those involving flow-cell studies and $\mathrm{pH}$ monitoring to provide relevant information obtained under similar conditions.

Migration and uptake tests should be devised to estimate the behavior of different radionuclides for various cement compositions. The samples should be studied using two different approaches. These two approaches are complementary and will provide an insight on the concrete behavior under different conditions.

First, tests should encompass column experiments with ground concrete through which a solution bearing the radionuclides will flow. The concrete could be ground more or less coarsely to investigate the effect of that parameter. Ground concrete placed in a column presents the advantage of being thoroughly representative of the concrete nature if it is inhomogeneous. It holds the disadvantage, however, of presenting a greater surface area than in reality, but this is easily overcome by considering a correction factor. Ground concrete is also more likely to retain radioelements effectively, leading to measurements in which the activity difference between the effluent and the raffinate is significant. The second approach should be closer to reality by considering the element migration through a concrete cylinder in the middle of which there is a whole that contains the radionuclide solution. Hydrostatic pressure will drive the migration phenomenon, which is anticipated to be slow. Measurements of the distribution through the concrete should then be carried out.

Iron-containing nanoparticles of silica can act as local reducing agents, which would make the radionuclides less mobile.

Researchers must have experience with radionuclide extraction, exchange, and transport through different media, such as solvents, resins, ion exchangers, and membranes. This experience should be applied to the testing of radionuclide migration through different kinds of concretes. Radionuclides relevant to the Yucca Mountain project include, but are not limited to, technetium-99 and iodide-129. Radioelements, such as uranium, plutonium, and neptunium, for which the isotope will not be specified, should be studied thoroughly because they represent the bulk of the elements present in the stored waste. All these elements can be analyzed by radioanalytical techniques $(\alpha, \beta$ scintillation counting, $\gamma$ counting) or by ICP-MS.

\section{Effects of High Temperatures on High-Silica Concretes}

In order to study the effect of temperatures that are expected to exist in the repository, a testing program must be developed. For each formulation selected ( 3 or 4$)$, the following tests should be performed. The specimen samples should be cured for 6 months prior to testing. After 6 months, a set of three samples should be tested for modulus of elasticity, compressive strength, and flexural strength. These data can be the reference for the samples that will undergo thermal treatment. Some samples should be heated slowly to a temperature of 66,150 and $250^{\circ} \mathrm{C}$ (Zadeh et al. 1998).

After reaching the selected temperature, the samples should be allowed to remain for 15 days ( \pm 5 days $)$ at this temperature. The oven can be turned off, and the samples should be allowed to cool down to room temperature inside of the oven. They should be removed $24 \mathrm{~h}$ after the ambient temperature is reached to prevent any gradient of temperature to exist in the sample. The samples should be removed from the oven, weighed, and tested for ultrasonic pulse velocity (Gowripalan et al. 1997, Malhotra et al. 1989). The prismatic samples should be tested for flexural strength, and the cylinders tested for compressive strength (Phan et al. 2002). The same tests should be performed to characterize the cured concrete: chemical analysis, X-ray diffraction, porosity, SEM, and permeability. 
Each formulation should use the following:

- $\quad$ Three prismatic samples per temperature (a total of 12 samples, including reference temperature)

- $\quad$ Five cylinders per temperature totalling 20 cylinder samples (three for compressive strength and two for permeability).

\section{Biodegradation Studies}

Rogers et al. (2003) have developed and tested an accelerated test for evaluating microbial influenced degradation (MID) of cement-solidified wastes. This improves the existing U.S. Nuclear Regulatory Commission (NRC) accelerated test, which cannot distinguish between degradation caused by biogenic acid produced under optimal conditions in a bioreactor and that caused by active biofilms formed on the waste materials. The key limitation of the NRC methods is that the nutrient levels significantly limit the activity of any developing biofilm.

A more realistic modified NRC test was proposed with separate biofilm formation and biofilm evaluation stages. The test removed nutrient limitations on biofilm growth and enabled the effects of MID resulting from active biofilms growing on waste forms to be examined. Aggressive MID microorganisms (T. thiooxidans) can form a biofilm on the surface of cement-solidified waste so that when nutrients are provided, the microbes remain active.

For the prevailing microorganisms expected in YM, cured concrete specimens should be submitted for testing under the guidelines and conditions of this modified NRC testing protocol.

\section{Chemical Analyses of Solid and Liquid Phases and Mineralogical Changes}

GFAA, IC, ICP-MS and ICP-AES are anticipated to be the principal tools for monitoring the composition and $\mathrm{pH}$ of the groundwater. However, the extent of dissolution of the cements is expected to be very small-below the limit of detection of normal analytical methods. Therefore, measuring the concentration of cement constituents in water may require analysis by radiochemical means. For example, ${ }^{90} \mathrm{Sr}$ could substitute for a small part of the calcium content.

\section{Characterize and Detect the Phases that Form due to Interaction with Groundwater}

Petrographic and SEMPA analyses and SEM and TEM imaging should be employed. Isotopic markers in the exposure studies will allow isotopic and elemental imaging using SIMS to track the migration of the fluid into the solid samples at the micro- and nanoscale.

\section{Cost Comparison Study}

In addition to having long-term durability superior to steel, the application of high-silica cements to the build-out and lining of the YM repository connecting tunnels and disposal drifts results in potential cost savings of $\$ 112 \mathrm{M}$ or more in construction costs.

The total system life-cycle cost for the Civilian Radioactive Waste Management System (CRWMS) was prepared as an estimate that aids in financial planning and provides policy makers with information for determining the course of the program. The life-cycle cost analysis includes the current repository design, including surface facilities, subsurface repository, and waste packaging. The waste should be placed in underground drifts (horizontal excavations) located in the emplacement block area. High-level waste packages should be placed in the drifts between the commercial spent nuclear fuel packages.

These estimates are not being interpreted as final because alternative designs and approaches for implementing the repository system have been and will continue to be analyzed.

The purpose of this task is to analyze the technical and economic impact of using concrete for the construction of the repository as it pertains to the building of the inverts as replacement of carbon steel. This design modification will impact the total life-cycle cost of the repository. Analysis of existing 
reports indicates global figures for the cost analysis. The Monitored Geological Repository (MGR) cost estimate to date comprises integrated costs from six time phases:

1. Development and evaluation

2. Licensing

3. Pre-emplacement construction

4. Emplacement operations

5. Monitoring

6. Closure and decommissioning

Most of these cost items need to be analyzed for this alternative project. It is forecasted that the preemplacement cost would be the cost item most impacted by the concrete construction alternative, followed by operations, licensing and closure, and decommissioning. On the original cost estimate, preemplacement represents about $13 \%(\$ 4,450 \mathrm{M})$ of the total life-cycle cost. This cost has been disaggregated as (1) surface ( $\$ 1,780 \mathrm{M})$; (2) subsurface $(\$ 1,200 \mathrm{M})$; (3) waste package and drip shield fabrication $(\$ 200 \mathrm{M})$; (4) performance confirmation $(\$ 330 \mathrm{M})$; and (5) regulatory, infrastructure and management support $(\$ 940 \mathrm{M})$. These costs correspond to procurement, design, and construction activities. The construction includes costs for site preparation and construction of surface and subsurface facilities.

It is forecasted that the emplacement operations cost item will also be impacted for this alternative project, mostly in the maintenance aspect of operations. The repository emplacement operations costs represent about $55 \%(\$ 19,710 \mathrm{M})$ of the total life-cycle cost.

Based on this information, the purposes of the cost analyses should be the following:

1. Investigate the details for the life-cycle cost analysis done for the repository.

2. Determine the cost of building the invert using concrete.

3. Determine the impact of item two in the total life-cycle cost of the repository.

\section{Models of the Aging of Cementitious Materials}

The laboratory and natural analog data will be compared with the prediction of current models of the aging of cementitious materials. For example, these models are based on the physical-chemical processes of degradation of OPC waste forms in water, their effects, and their time scales. These models include the effects when the silica concentration rises in the adjacent solution and an aluminosilicate film greatly reduces the dissolution rate. Such a model shows that a higher dissolved silica concentration in the interstitial solution stabilizes this protective layer (Faucon et al. 1998). In conjunction with the results from the natural analogs studies, attempts should be made to extrapolate the cement performance and its long-term impacts on the source term to the YMP risk models.

Physical-chemical models should be selected that couple the transport of water, chloride, and heat that can be conservative predictors of cement aging. These models have reproduced well some data observed from in situ exposures (Petre-Lazar et al. 2003). In addition, there are models that allow variable exposures with a thermodynamic coupling of moisture transport, cement paste hydration, and microstructure phenomenology (Ishida and Maekawa 2003). Models of thermal degradation in concretes have been applied to test specimens at NIST (Phan et al. 2002).

In the context of the YM repository, there have been coupled studies for the Stripa mine in Sweden that describes a detailed mechanism-based model of spent-fuel dissolution in an oxidizing deep repository setting with canister and near-field transport (Longcheng and Neretnieks 2001). 


\section{Anthropogenic Analog Tasks}

In order to facilitate this process, researchers must work closely with archaeologists (see Appendix A) from the countries in question (primarily Italy, but contacts should be made with archaeologists in the United States, as well as in Great Britain, Israel, and elsewhere who may have samples that can be examined). ORNL has an agreement in place with Dr. V. Lucarelli of the Societa Analisi Strutturale and Dr. F. Vestroni, Professor and Head of the Department of Structural and Geotechnical Engineering at the University of Rome, La Sapienza (see attached letter), and Mr. David Moore, an engineer who has made a special study of the origins of Roman cements (see attached letter) to aid in this collection. Dr. Vestroni already has samples he has agreed to provide from Basilica of Messenzio and Harbor of Ostia Antica (ancient harbor of Rome by the sea) and is currently helping make contact with the Natural Cultural Heritage Authority, whose permission will be needed to obtain additional materials. Additional contacts are being sought in Italy, Israel, and Great Britain in order to obtain a wider array of materials, but initial contacts are already sufficient to assure that some materials can be obtained.

\section{Natural Analog Tasks}

Initial efforts should focus on collecting samples from four localities: Marble Canyon and the Christmas Mountains in west Texas, Scawt Hill, Northern Ireland, and the Hatrurim formation in Israel. Detailed descriptions of the geology, metamorphism, and mineralogy of these localities can be found in Appendix B. These have been selected for several reasons: (1) the rocks at these localities contain phases that are very similar to high-silica cements (e.g., melilite, monticellite, merwinite, rankinite and spurrite); (2) these localites are very well known and characterized; (3) access to these localites is relatively simple; and (4) the rocks at these localities have been exposed to weathering in a variety of environments for reasonably long periods of time (>100,000 years). For example, Marble Canyon and the Christmas Mountains in west Texas and the Hatrurim formation in Israel occur in dry desert environments, whereas Scawt Hill, Northern Ireland, occurs in a region with high precipitation. Thus, rocks from each of these localities can be used to predict how high-silica cements will respond in the repository over the mandated time periods, and the differences between them will provide data on how environmental variables affect this prediction.

Sampling geological examples is typically far easier than obtaining samples from archaeological contexts insofar as most countries do not object to sampling or export. Nonetheless, when samples of a particular mineralogy are needed from relatively large terrains, the help of local experts will greatly facilitate sampling. Of the four localites outlined above, only one, the Hatrurim formation, will require outside help. Marble Canyon, Scawt Hill, and the Christmas Mountains are small enough that experienced geologists should be able to locate and sample the appropriate outcrops without assistance.

The Hatrurim formation, however, has outcrops in at least nine widely separate areas, including the Hatrurim syncline west of the Dead Sea, Ma'aleh Adumim, Beit Sahur, Nebi Musa and Jebel Harmun in the Judean Desert, Nahal Ayalon in the Coastal Plain, Kefar Uriyya and Tarqumiye in the Shefela region (western foothills), and Nahal Malhata in the Be'er Sheva' Valley in the northern Negev (of these, four and possibly five fall within the boundaries of pre-1967 Israel and can currently be visited in relative safety, including the major outcrop in the Hatrurim syncline). In its fully developed occurrence in the Hatrurim syncline the complex has a preserved thickness of more than $220 \mathrm{~nm}$ and covers an area of 50 $\mathrm{km}^{2}$. Thus, there are a number of localites, and a great deal of area to potentially cover to find the appropriate materials. In order to solve this problem, contacts have been made with three Israeli geologists, Drs. Y. Kelodny and A. Matthews of the Hebrew University of Jerusalem, and Avi Burg of the Geological Survey of Israel (see attached letters), each of whom has extensive experience working in the Hatrurim rocks. They have agreed to lead the necessary field trips to collect samples, and to collaborate in any other ways needed in order to be sure that the appropriate samples for this research will be obtained. 


\section{Laboratory Examination on Anthropogenic and Natural Samples}

After the samples have been obtained, the alteration phases that formed during weathering must be characterized in order to understand the mechanisms and time scale of alteration that occurred during the weathering process. Researchers should employ a number of techniques to characterize these samples, including, petrography, electron microprobe analysis, X-ray diffraction, ICP-MS, ICP-AES, and accelerator mass spectrometry (AMS). Specific areas of study include:

- Mineral paragenesis. To understand the log-term effects of the exposure of natural cements to the environment, it is imperative to develop a detailed mineral paragenesis that identifies and distinguishes between primary minerals and secondary alteration phases. This will allow the development of reaction paths for various minerals, allowing the determination of the physiochemical characteristics (e.g., $\mathrm{pH}$ ) of the fluids that formed these phases, and develop a thermodynamic model for the natural cement that will provide input parameters for PA models. This approach will allow determination of the chemical composition of cements that is most stable and robust under geological conditions.

- Exposure ages. In order to evaluate the effects of fluid-rock interaction associated with these natural cements, it is important to link the extent of alteration with the length of time the samples were exposed to surface or near surface environments. Although the ages of archaeological artifacts are documented, the exposure ages of older geological samples need to be quantified. Cosmogenic radionuclide pairs such as ${ }^{10} \mathrm{Be}$ and ${ }^{9} \mathrm{Be},{ }^{26} \mathrm{Al}$, and ${ }^{26} \mathrm{Mg}$ can be used to determine the exposure ages of terrestrial rocks. Both ${ }^{10} \mathrm{Be}$ and ${ }^{26} \mathrm{Al}$ are produced by direct cosmic-ray irradiation of rocks at the surface of the Earth (Jha et al. 1982, Xue et al. 1995). Both nuclides are unstable and decay to ${ }^{9} \mathrm{Be}$ and ${ }^{26} \mathrm{Mg}$, respectively (Lal and Peters 1967, Arnold 1956). The halflife of ${ }^{10} \mathrm{Be}$ is 1.5 million years and the half-life of ${ }^{26} \mathrm{Al}$ is 716,000 years (Faure 1986). Therefore, by measuring the isotopic ratios ${ }^{10} \mathrm{Be} /{ }^{9} \mathrm{Be}$ and ${ }^{26} \mathrm{Al} /{ }^{26} \mathrm{Mg}$, the exposure ages of the various cements can be quantified.

Researchers can use a multi-collector ICP-MS to measure the ${ }^{10} \mathrm{Be} /{ }^{9} \mathrm{Be}$ and ${ }^{26} \mathrm{Al} /{ }^{26} \mathrm{Mg}$ ratios. However, an AMS should be used to measure the desired isotopic ratios in some samples because of the low levels of ${ }^{10} \mathrm{Be},{ }^{9} \mathrm{Be},{ }^{26} \mathrm{Al}$, and ${ }^{26} \mathrm{Mg}$ in some terrestrial rocks (Faure 1986). This approach will allow determination of the length of time these samples were exposed to geological conditions and link these ages with the chemical composition of cements. Therefore, this will allow demonstration of the effects of long-term exposure to the environments over geological length scales.

These results should be compared with the results obtained from using these same analytical techniques on the high-silica concretes from the static and flow-through exposure tests. This comparison and the results from the cement-aging modeling will increase the confidence in extrapolating the physical and chemical properties of the proposed YM construction materials. An estimate of the potential impacts on the YMP long-term risk analyses can then be made. 


\section{WORK BREAKDOWN, COSTS, AND SCHEDULE}

The following represents a "strawman" work breakdown structure with preliminary estimates of scope, schedules, and costs for a comprehensive program that incorporates all of the previous tasks, except for the RF work. It shows the relationships between the various tasks that were identified in this report. The estimated times and costs are based on estimates of specific methods of performance and should only be used as a guide for future planning and budgeting. 



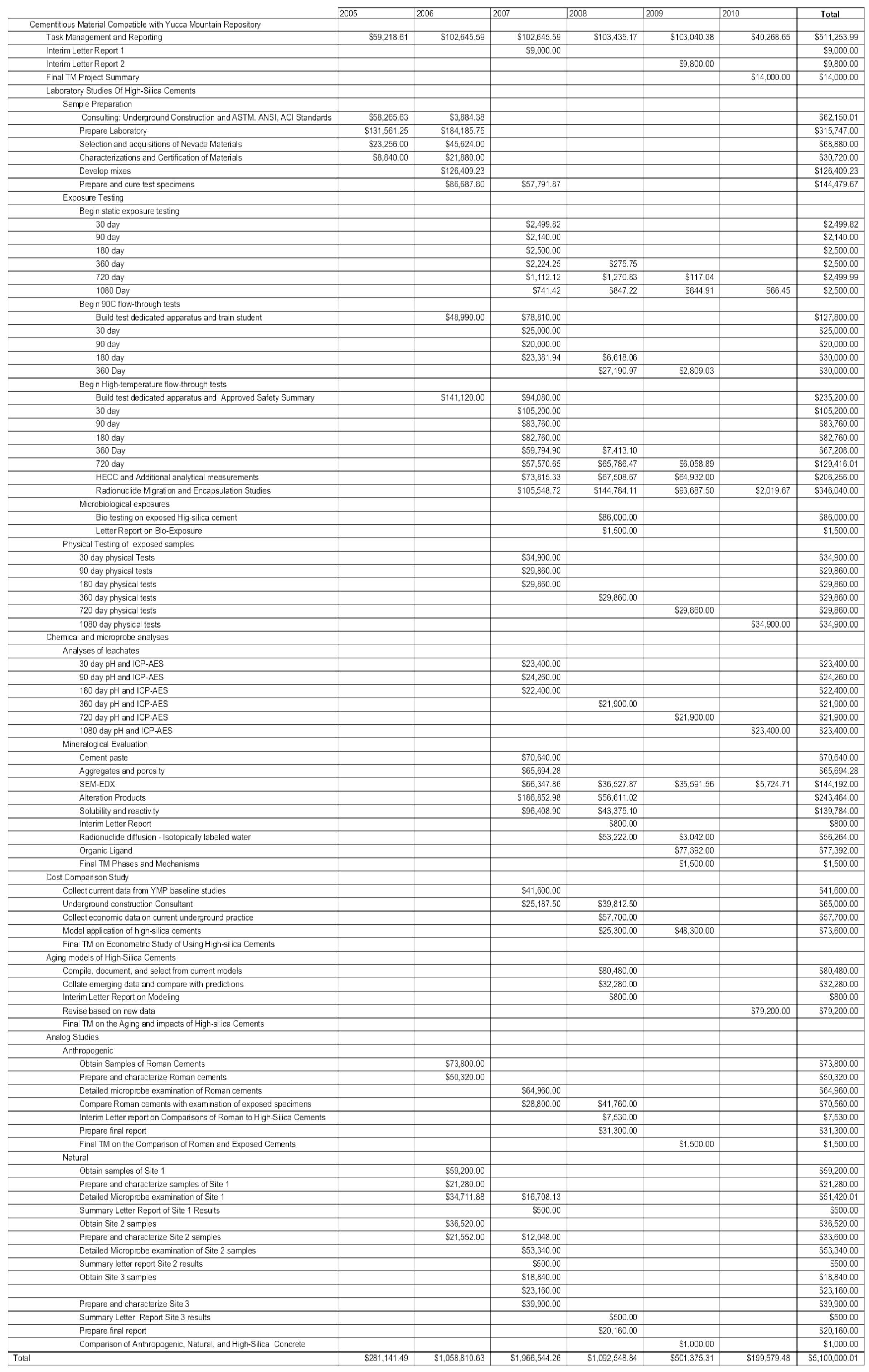





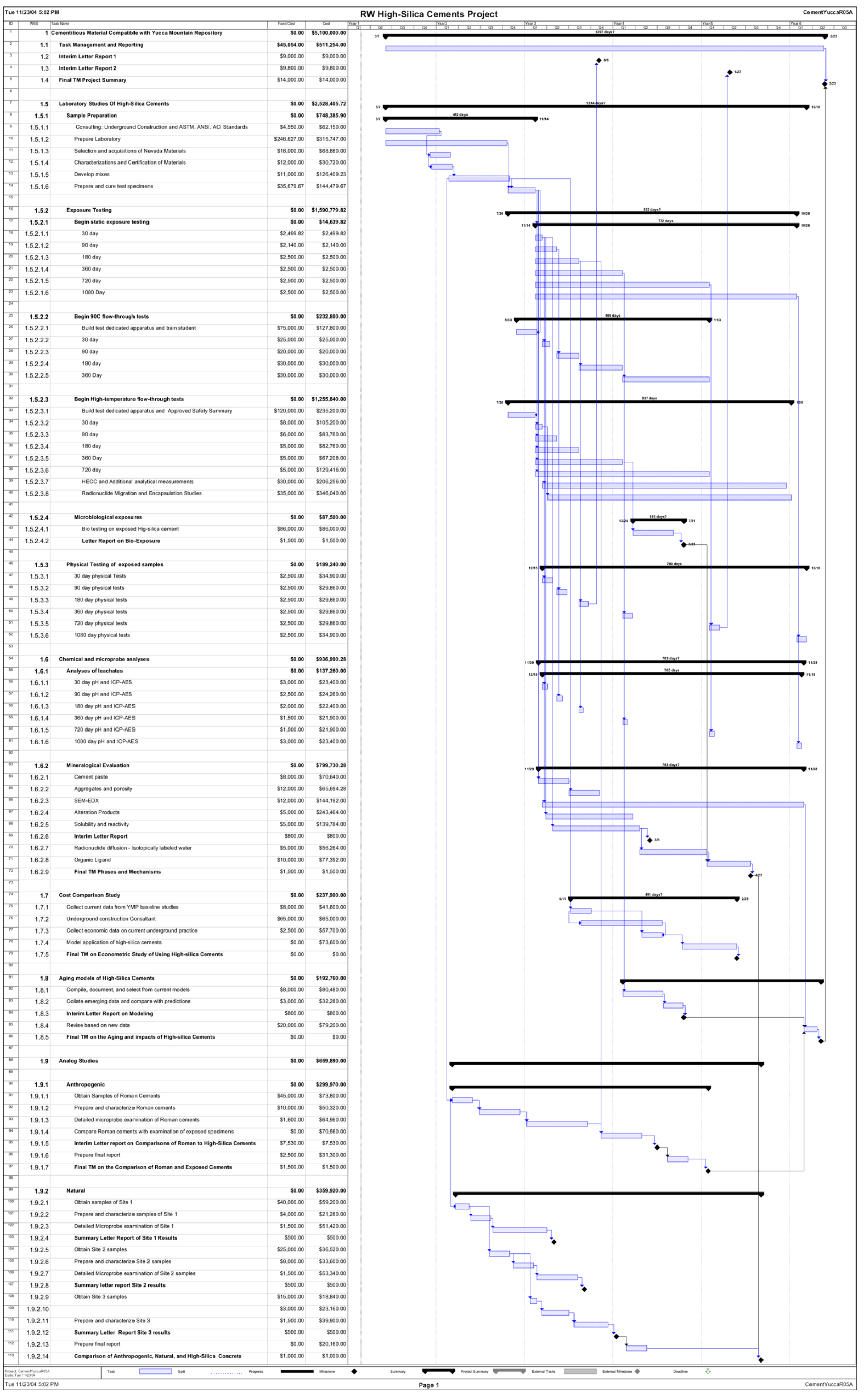





\section{REFERENCES}

ACI 221R-96. 2001. "Guide for Use of Normal Weight and Heavyweight Aggregates in Concrete." ACI 233R-03. 2004. "Slag Cement in Concrete and Mortar."

ACI SP-114. 1989. "Fly Ash, Silica Fume, Slag, and Natural Pozzolans in Concrete." Proceedings of Third International Conference, 2, Trondheim, Norway, SP-114, V. M. Malhotra, Ed., American Concrete Institute, Farmington Hills, Mich., pp. 1579-1596.

ACI 211.1-97. 1997. "Standard Practice for Selecting Proportions for Normal, Heavyweight, and Mass Concrete, American Concrete Institute."

Agrell, S.O. 1965. "Polythermal metamorphism of limestone at Kilchoan, Ardnamurchan (Scotland)." Min. Mag. 34, 1-15.

Anderson, G. M. 1996. Thermodynamics of Natural Systems, “Chapter 9: Redox Reactions.” University of Toronto, John Wiley \& Sons, Inc., Toronto.

Anovitz, L. M. and R. M. Kalin. 1990. "High-Temperature Metamorphism Around the Marble Canyon Intrusion, West Texas." Geol. Soc. Amer. Abst. 22, A258.

Anovitz, L. M., R. M. Kalin; and J. Ruiz. 1992. "Constraints on Fluids and Mass Transfer During HighTemperature Contact Metamorphism: Marble Canyon West Texas." Geol. Soc. Amer. Abst. 24, A263.

Anovitz, L. M.; R. M. Kalin; and J. Ruiz. 1991. "High-Temperature Contact Metamorphism: Marble Canyon West Texas. GSA Abst. w. Prog., Mineralogical Society of America Symposium. Contact Metamorphism, 23, A50.

Archibald, James F., Charles W. Pelley, Samantha J. Espley, and David O. DeGagné, 2004. "Economic and Productivity Comparison of Bolt and Screen, Shotcrete and Polymer Rock Support Methods," http://mine.queensu.ca/people/faculty/Archibald/SupportCostsPaper.pdf .

Arnold, C. A. 1956. "A New Calamite from Colorado." Contributions from the Museum of Paleontology. University of Michigan. 13, 6, pp. 161-173.

ASTM C 136-01. 2001. "Standard Test Method for Sieve Analysis of Fine and Coarse Aggregates."

ASTM C 150 - 02a. "Standard Specification for Portland Cement."

ASTM C 595 - 03. "Standard Specification for Blended Hydraulic Cements."

ASTM C 618-99. "Standard Specification for Coal fly Ash and Raw or Calcined Natural Pozzolan for Use as Admixtures in Concrete."

ASTM C 989 - 04. "Standard Specification for Ground Granulated Blast-Furnace Slag for Use in Concrete and Mortars."

Atkinson, A.; J. A. Hearne; C. F. Knights. 1989. "Aqueous Chemistry and Thermodynamic Modeling of CaO-SiO2-H2O Gels.” J. Chem. Soc., Dalton Trans. 10, pp. 2371- 2379.

Atkinson, A., and J. A. Hearne. 1989. The Hydrothermal Chemistry of Portland Cement and its Relevance to Radioactive Waste Disposal, Nirex Report NSS/R187.

Atkinson, A.1985. The Time Dependence of pH Within a Repository for Radioactive Waste Disposal. UKAEA Report AERE-R11777, UKAEA, UK.

Atkinson, A; N. M. Everitt; R. Guppy. 1987. Evolution of pH in a Radwaste Repository: Experimental Simulation of Cement Leaching. UKAEA Report AERE-R12594, UKAEA, UK.

BCAA00000-01717-0200-00013 REV 00, Sections 6.2.1- 6.2.2, "Evaluation of Alternative Materials for Emplacement Drift Ground Control, pp. 7-8 (referring to greater peak 10,000 year doses, Table 61).

Bénézeth, P.; D. A. Palmer, D. J. Wesolowski, and C. Xiao. 2002. "New Measurements of the Solubility of Zinc Oxide from 150 to $350^{\circ}$ C," J. Solution Chem., 31, 947-973.

Bénézeth, P.; D. A. Palmer; and D. J. Wesolowski. 1999. "The Solubility of Zinc Oxide in 0.03m Ionic Strength as a Function of Temperature with in situ pH Measurement," Geochim. Cosmochim. Acta, 63, 1571-1586.

Bentor Y. K.; M. Kastner; I. Perlman; Y. Yellin. 1981. "Combustion Metamorphism of Bituminous 
Sediments and the Formation of Melts of Granitic and Sedimentary Composition." Geochimica et Cosmochimica Acta 45 (11): 2229.

Berner, U. R. 1992. "Evolution of Pore Water Chemistry During Degradation of Cement in a Radioactive Waste Repository Environment." Waste Management 12, pp. 201- 219.

Berner, U.R. 1988. "Modelling the Incongruent Dissolution of Hydrated Cement Minerals, Radiochim." Acta 44/45, pp. 387-393.

Boyle. 2002. SD-S241-310-11, "Chapter 9: Tunnel Investigations and Cost Estimates," Boyle Inc., 7807 Convoy Court, Suite 200, San Diego, California.

Bridge, T. E. 1966b. "Bredigite, Larnite, and Dicalcium Silicates from Marble Canyon." Amer. Mineral. 51, 1766-1774.

Bridge, T. E. 1980. "Progressive Metamorphism of Permian Siliceous Limestone and Dolomite - A Complete Sequence Around a Monzonite Intrusion, Marble Canyon, Diablo Plateau, Texas." New Mexico Geol. Soc. Guidebook, $31^{\text {st }}$ Field Conference, Trans-Pecos Region, 225-229.

Bridge, T. E. 1986. "Contact Metamorphism Around the Marble Canyon Stock.” In J. G. Price, C. D. Henry, D. F. Parker, and D. S. Barker, Eds., Igneous Geology of Trans-Pecos, Texas: Field Trip Guide and Research Articles. Univ. Texas Bur. Econ. Geol. Guidebook 23, 26-30.

Bridge, T. E.1966a. Contact Metamorphism in Siliceous Limestone and Dolomite in Marble Canyon and Geology of Related Intrusion, Culberson County, Trans-Pecos, Texas. Ph.D. Thesis, Univ. of Texas, Austin.

Brookins, D. G. 1976. Shale as a Repository for Radioactive Waste: The Evidence from Oklo, Environ. Geol. 1, pp. 225-269.

Bruton, C. J. and H. F. Shaw. 1988. "Geochemical Simulation of Reaction Between Spent Fuel Waste Form and J-13 Water at $25^{\circ} \mathrm{C}$ and $90^{\circ} \mathrm{C}$." In M.J. Apted and R.E. Westerman, Eds., Scientific Basis for Nuclear Waste Management XI. Materials Research Society Proceedings, 112, pp. 473484.

Burnham, C. W. 1959. "Contact Metamorphism of Magnesian Limestones at Crestmore, California." Bull. Geol. Soc. Am. 70, 879-920.

Calleja, J. 1997. "Performance and Durability of Cementitious Materials." Proceedings of the $10^{\text {th }}$ International Congress on the Chemistry of Cement Vol. 4, Gothenburg, Sweden, June 2-6.

Calleja, J., Ed. 1980. International Congress on the Chemistry of Cement. Vol. I, Ed. Sephina, Paris, France.

Capitani, G. C.; H. Leroux; J. C. Doukhan; S. Rios; M. Zhang; E. K. H. Salje. 2000. “A TEM Investigation of Natural Metamict Zircons; Structure and Recovery of Amorphous Domains." Physics and Chemistry of Minerals 27, 8, pp. 545-556.

Carothers, W.W. and Y. K. Kharaka. 1978. "Aliphatic Acid Anions in Oil-Field Waters; Implications for Origin of Natural Gas.” AAPG Bulletin 62; 12, pp, 2441-2453.

Chapman, N. A.; McKinley, I. G.; and Smellie, J. 1984. The Potential of Natural Analogs in Assessing Systems for Deep Disposal of High-Level Radioactive Waste. NAGRA Tech. Rept. NTB 84-41.

Chen, F.; R. C., Ewing; and S. B., Clark. 1999. "The Gibbs Free Energies and Enthalpies of U ${ }^{6+}$ Phases: An Empirical Method of Prediction." American Mineralogist Vol. 84, pp 650-664.

Cherniak, D.J. 2000. "Rare Earth Element Diffusion in Apatite." Geochimica et Cosmochimica Acta. 64, 22, pp. 3871-3885.

Cherniak, D.J. and E. B. Watson. 2001. "Pb Diffusion in Zircon.” Chemical Geology. 172, 1-2, pp. 5-24.

Clabaugh, S.1953. "Contact Metamorphism in the Christmas Mountains, Brewster County, Texas." Bull. Geol. Soc. Amer. 64, 1408.

Czernin, W. 1962. Cement Chemistry and Physics for Civil Engineers. Chemical Publishing Co. Inc., New York, 139 p.

Daube, J. and R. Bakker.1986. Portland Blast-Furnace Slag Cement: A Review. ASTM-STP 897, G. Frohnsdorff, Ed., American Society for the Testing and Materials, Philadelphia, pp. 5-14. 
Davis, J.A. and D. B. Kent. 1990. "Surface Complexation Modeling in Aqueous Geochemistry," Rev. Mineral. 23, pp. 177-260.

De Belie, N.; Hans Jurgen Verselder; Benny De Blaere; Dirk Van Nieuwenburg; and Reinhart Verschoore. 1996. Influence of the Cement Type on the Resistance Concrete to Feed Acids, Cement and Concrete Research, Vol. 26, No. 11, pp.1717-1725.

Dodge, C. J.; A. J. Francis; J. B. Gillow; G. P. Halada; C. Eng; and C. R. Calton. 2002. "Association of Uranium with Iron Oxides Typically Formed on Corroding Steel Surfaces.” Environ. Sci. Techno. 36, pp. 3504-351.

Dole, L. R. 1991. "Fixation of Pumping Station Contaminated Soils." Proceedings of the HMCRINortheast '91 Conference, Hazardous Materials Control Research Institute, Boston, Massachusetts, pp. 292-293, July 10-12.

Dole, L. R.; M. W. Grutzeck; and P. H. Licastro. 1993, "Final Report: Performance Verification Study on the Solidification/Stabilization Waste Form for PCB-Contaminated Soils at the Rail Yard in Paoli, Pennsylvania.” Ogden Environmental and Energy Services, 1009 Commerce Park Drive, Oak Ridge, Tennessee, 37830, January 28.

Eakle, A. S. 1917. "Minerals Associated with the Crystalline Limestone at Crestmore, Riverside County, California.) Univ. Calif. Bull. Dept. Geol. 10, 327-360.

Ehrenburg, D. O. 1980. "An Analytical Approach to Gap-Graded Concrete." Cement, Concrete, and Aggregates Vol. 2, No. 1, pp. 39-42.

Eng, C. W.; G. P. Halada; A. J. Francis; C. J. Dodge; and J. B. Gillow. 2003. "Uranium Association with Corroding Carbon Steel Surfaces." Surf. Interface Anal. 35, pp. 525-535.

Ewing, R. C. 1979. "Natural Glasses: Analogs for Radioactive Waste Forms.” Mater. Res. Soc. Symp. Proc. 1, 57-68.

Faucon, P.; F. Adenot; J. F. Jacquinot; J. C. Petit; R. Cabrillac; and M. Jorda, M. 1998. "Long-Term Behavior of Cement Pastes used for Nuclear Wastes Disposal: Review of Pysico-Chemical Mechanisms of Water Degradation." Cement and Concrete Reseach Vol. 28(6), pp. 847-857.

Faure, G. 1986. Principles of Isotope Geology. Wiley and Sons, New York, 589 p.

Fayek, M. and T. K. Kyser. 1997. "Characterization of Multiple Fluid Events and Rare Earth-Element Mobility Associated with Formation of Unconformity-type Uranium Deposits in the Athabasca Basin, Saskatchewan." Can. Min., 35, 627-658.

Fein, J. B. 1994. "Porosity Enhancement During Clastic Diagenesis as a Result of Aqueous MetalCarboxylate Complexation: Experimental Studies." Chemical Geology. 115, 3-4, pp. 263-279.

Finch, R. J. 1994. Paragenesis and Crystal Chemistry of the Uranyl Oxide Hydrates. Ph.D. thesis, University of New Mexico.

Finch, R. J. 1997. "Thermodynamic Stabilities of U(VI) Minerals: Estimated and Observed Relationships, Scientific Basis for Nuclear Waste Management XX," Materials Research Society Proceedings, W.J. Gray and I.R. Triay, Eds., 465, pp. 1185-1192.

Flint, L. E. 1998. Characterization of Hydrogeologic Units Using Matrix Properties, Yucca Mountain, Nevada, Water-Resources Investigations Report 97-4243. US Geological Survey, Denver, CO, 64 pp.

Freeze, R. A. and A. J. Cherry. 1979. Groundwater. Prentice-Hall, Inc., Englewood Cliffs, New Jersey, pp. 254-289.

Fulton, F. S. 1974. The Properties of Portland Cement Containing Milled Granulated Blast-Furnace Slag. Monograph, Portland Cement Institute, Johannesburg, pp. 4-46.

Gaal, G. C. M.; A Van Beck; J.D. Baker; and J. C. Walraven. 2003. "Coefficient of Diffusion Derived from Structure Exposed to Chloride More than 60 Years Old." Proceedings of the 2nd International Workshop on Life Predication and Aging of Management of Concrete Structures, Paris, France. May 5-6, PRO 29, RILEM Bagneux, France, pp. 21-29.

Geisler, T.; R. T. Pidgeon; W. van-Bronswijk; R. Kurtz. 2002. "Transport of Uranium, Thorium, and Lead in Metamict Zircon under Low-Temperature Hydrothermal Conditions." Chemical Geology 191, 1-3, pp. 141-154. 
Giere, R. 1989. Isotopic Composition of Sulfides in Ti-rich Veins from the Adamello Contact Aureole (Italy). Annual Report of the Director, Geophysical Laboratory, Carnegie Institution. pp. 33-37.

Giordana S.; I. Mabille; and C. Fiaud. 2003. "Inhibiting Effect of Silicates on Corrosion of Low Silicon Alloyed Steels in Neutral Non-Oxidizing Conditions at $90^{\circ}$ C." Corrosion Engineering, Science and Technology 38 (no. 4), pp. 291-297(7), December 1.

Giordano, T.H. and Y. K. Kharaka.1994. "Organic Ligand Distribution and Speciation in Sedimentary Basin Brines, Diagenetic Fluids and Related Ore Solutions.” Geological Society Special Publications 78; pp. 175-202.

Glasser F. P. 1993. Chemistry of Cement-Solidified Waste Forms, in Chemistry and Microstructure of Solidified Waste Forms. Edited by R. D. Spence, Oak Ridge National Laboratory, Lewis Publishers.

Glasser, F. P., S. Diamond; and D. M. Roy. 1986. "Hydration Reactions in Cement Pastes Incorporating Fly Ash and Other Pozzolanic Materials." Proceedings of the Materials Research Society Vol. 85, Microstructural Development During Hydration of Cement, L.J. Struble and P.W. Brown, Eds., December 2-4, Boston, Massachusetts, Materials Research Society, Pittsburgh, Pennsylvania, pp. $167-186$.

Glasser, F. P.; M. J. Angus; C. E. McCulloch; D. Macphee; and A. A. Rahman. 1985. "The Chemical Environment in Cements." In C. M. Jantzen, J. A. Ewing, R. C. Ewing (Eds.), Scientific Basis for Nuclear Waste Management VIII, MRS Symposia Proceedings, Vol. 44, Materials Research Society, Pittsburgh, PA, pp. 849- 858.

Glasser, F.P. and S.-Y. Hong. 2003. "Thermal Treatment of C-S-H Gel at $1 \mathrm{Bar}^{\mathrm{H}} \mathrm{H}_{2}$ pressure up to $200^{\circ} \mathrm{C}, "$ Cement and Concrete Research, 33, 271-279.

Goldschmidt, V. 1911. "The Nature of Crystals." Science 33, p. 871.

Gowripalan, N., P. Salonga, and C. Dolden.1997. "Residual Strength of High-Performance Concrete Subjected to High Temperatures," in proceedings of ACI International Conference on HighPerformance Concrete, Malaysia, ACI SP-172-10, pp. 171-191.

Gross, S. 1970. "Mineralogy of the 'Mottled Zone' Complex in Israel: List of Minerals.” Israel J. Earth Sci. 19, pp. 211-216.

Gross, S. 1977. "The Mineralogy of the Hatrurim Formation, Israel." Israel Geol. Surv. Bull. 70, 80 pp.

Gur D.; G. Steinitz; Y. Kolodny; A. Starinsky; M. Mcwilliams.1995. "Ar/Ar Dating of Combustion Metamorphism ("Mottled Zone", Israel)." Chemical Geology 122 (1-4), pp. 171-184.

Harris, A. W. 1998. An Assessment of the pH Buffering Provided by the Nirex Reference Vault Backfill Within a Radioactive Waste Repository, Nirex Report NSS/R323.

Harris, A. W.; A. Atkinson; V. Balek; K. Brodersen; G. B. Cole; A. Haworth; Z. Malek A. K. Nickerson; K. Nilsson; A. C. Smith. 1997. The Performance of Cementitious Barriers in Repositories. European Commission Report EUR-17643 EN, Office for Official Publications of the European Communities, Luxembourg.

Harris, A. W.; M. C. Manning; W. M. Tearle; and C. J. Tweed. 2002. "Testing of Models of the Dissolution of Cements-Leaching of Synthetic CSH Gels," Cement and Concrete Research 32, pp. 731-746.

Herrera, L. K.; C. E. Arroyave; and H. A. Videla. 2003. PRO 34, "The Use of Methods for Material Characterization, Surface Analysis Techniques and Atmospheric Aggressiveness in the Study of the Biodegradation of Two Sites of Cultural Heritage in the City of Medellin, Columbia."

Proceedings of the International RILEM Conference on Microbial Impact on Building Materials, September 8-9, 2003. Lisbon, Portugal. M.R. Silva, Ed., RILEM Publications, S.A.R.L., Bagneux, France, pp. 13-23.

Hoek and Brown. 1980. Underground Excavations in Rock. Institute on Mining and Metallurgy, London, England.

Homme, F.C. and A. Rosenzweig. 1958. "Spurrite and Monticellite Skarns in the Tres Hermanas Mountains, Luna County, New Mexico.” Bull. Geol. Soc. Amer. 69, p. 1586. 
Hooton, D. R.1986. Permeability and Pore Structure of Cement Pastes Containing Fly Ash, Slag, and Silica Fume, Blended Cements. ASTM-STP 897. G. Frohnsdorff, Ed., American Society for the Testing and Materials, Philadelphia, pp. 128-143.

Hoyle, S. Q.1988. Cesium and Strontium Partitioning During Hydration of Calcium Aluminosilicates. Ph.D. thesis, The Pennsylvania State University, University Park.

Hughes, C. J.1960. "An Occurrence of Tilleyite-Bearing Limestones in the Isle Rhum, Inner Hebrides." Geol. Mag. 97, pp. 384-388.

IAEA. 1989. Natural Analogs in Performance Assessment of the Disposal of Long-Lived Radioactive Waste. Technical Report series No. 304.

Idachaba, M. A.; K. Nyvor; N. O. Egeibor; and R. D. Rogers. 2003. "Limitation of the NRC Method for Microbial Stability Evaluation of Waste Forms." Advances in Environmental Research Vol. 7 , Issue 2, pp. 273-281.

Ishida, T., and K. Maekawa. 2003. "Modeling of Durability Performance of Cementitious Materials and Structures Based on Thermo-Hygro Physics." Proceedings of the 2nd International Workshop on Life Predication and Aging of Management of Concrete Structures. Paris, France, May 5-6, PRO 29, RILEM Bagneux, France, pp. 39-49.

Iwaki, K., A. Hirama, K. Mitani, S. Kaise, K. Nakagawa. 2001. Technical Research Institute, Tobishima Corporation, Chiba, Japan., "A Quality Control Method for Shotcrete Strength by Pneumatic Pin Penetration Test,” NDT\&E International, 34(6), pp. 395-402.

Jamtveit B.; S. Dahlgren; H. Austrheim. 1997. "High-Grade Contact Metamorphism of Calcareous Rocks from the Oslo Rift, Southern Norway." American Mineralogist. 82, 11-12, pp. 1241-1254.

Jasmund, K. and G. Hentschel. 1964. "Seltene Mineralparagenesen in den Kalksteineinschlussen der Lava des Ettringer Bellerberges bei Mayen (Eifel)." Beitr. Miner. Petrog. 10, 296-314.

Jha, K. and J. G. Laguros.1982. "X-ray Diffraction and Electron Microscopic Studies of Raw and Stabilized Oklahoma Shales." Indian Geotechnical Journal. 12, 3, pp. 227-236.

Joesten, R. 1974. "Local Equilibrium and Metasomatic Growth of Zoned Calc-silicate Nodules from a Contact Aureole, Christmas Mountains, Big Bend Region, Texas.” Am. J. Sci. 274, 876-901.

Joesten, R. and G. Fisher. 1988. "Kinetics of Diffusion Controlled Mineral Growth in the Christmas Mountains (Texas) contact Aureole. Geol. Soc. Am. Bull. 100, 714-732.

Joesten, R. 1976. "High-Temperature Contact Metamorphism of Carbonate Rocks in a Shallow Crustal Environment, Christmas Mountains, Big Bend Region, Texas." Amer. Mineral. 61, 776-781.

Joesten, R. 1977. "Mineralogical and Chemical Evolution of Contaminated Igneous Rocks at a GabbroLimestone Contact, Christmas Mountains, Big Bend Region, Texas." Geol. Soc. Am. Bull. 88, 1515-1529.

Joesten, R. 1983. "Grain Growth and Grain Boundary Diffusion in Quartz from the Christmas Mountains (Texas) Contact Aureole.” Am. J. Sci. 283-A (Orville Vol.), 233-254.

Joesten, R. 1991. "Local Equilibrium in Metasomatic Processes Revisited: Diffusion-Controlled Growth of Chert Nodule Reaction Rims in Dolomite. Amer. Mineral. 76, 743-755.

Jull, S. P; and T. P. Lees. 1990. Studies of Ancient Concrete. CEC Technical Report No. 12972, CEC Brussels.

Kersten, M. 1996. "Aqueous Solubility Diagrams for Cementitious Waste Stabilization Systems: 1. The C-S-H Solid-Solution System.” Environ. Sci. Technol. 30, pp. 2286- 2294.

Kleinlogel, A. 1960. "L' Influence des Divers Elements Physicochimiques sur les Betons," pp. 4-9. Dunod, Paris.

Kolodny Y. and S. Gross. 1974. "Thermal Metamorphism by Combustion of Organic-Matter - Isotopic and Petrological Evidence." Journal of Geology 82 (4): 489-506.

Kolodny Y., M. Bar; E. Sass 1973. "Fission Trackage of Mottled Zone Event in Israel." Earth and Planetary Science Letters 11 (4): 269.

Kolodny Y.; N. Schulman; S. Gross. 1973. "Hazeva Formation Sediments Affected by Mottled Zone Event." Israel Journal Of Earth Sciences 22 (3): 185-193. 
Kraynov, S.R. 1969. "Migration Rate of Nb in Groundwaters of Alkali Massifs and Accumulation in Weathering Crusts." Geochemistry International. 6, 5, pp. 1011.

Kumar, Dheer, P. K. Behera, U. K. Singh. 2002. Res. Scholar, Mining Dep., Indian Inst. Technology, Kharagpur, India, "Shotcreting in Rock Excavation and its Adhesion Strength," Electronic Journal of Geotechnical Engineering (online computer file) 7. http://geotech.civen.okstate.edu/ejge/2002/Ppr0203/Ppr0203.htm

Lacroix, R. and P. Rossi. 2000. "BEFIM: The French National Project for the Industrial Development of Metal Fiber Reinforced Concrete," RILEM Proceedings PRO 15, Fiber-Reinforced Concretes (FRC), pp. 19-27.

Lal, D. and B. Peters. 1967. "In-situ Cosmogenic (Super 14) C; Production and Examples of its Unique Applications in Studies of Terrestrial and Extraterrestrial Processes." Radiocarbon. 43, 2B, pp. 731-742.

Langmuir, D.1978. "Uranium Solution-Mineral Equilibrium at Low Temperatures with Applications to Sedimentary Ore Deposits." Geochimica et Cosmochimica Acta Vol. 42(6), pp. 547-569.

Li, Shu-t'ien and V. Ramakrishnan. 1974. "Gap-Graded Concrete Optimum Mixture Proportioning." Proportioning Concrete Mixes, SP-46, American Concrete Institute, Detroit, pp. 65-75.

Li, Shu-t'ien; V. Ramakrishnan; and B. V. Rangan. 1969. Workability of Gap-Graded Versus Continuously-Graded Concrete and Correlation between Slump and Vibe Time. Technical Report No. 3, State of South Dakota Department of Highways/U.S. Bureau of Public Roads, 34 pp.

Longchen, L.; and I. Neretneiks. 2002. "A Reactive Transport Model for the Oxidative Dissolution of Spent Fuel and Release of Nuclides within a Defective Canister." Nuclear Technology Vol. 137 (3), pp. 228-240.

Machesky, M. L.; D. A. Palmer, and D. J. Wesolowski. 1994. "Hydrogen Ion Binding at the Rutile-Water Interface to $250^{\circ} \mathrm{C}, "$ Geochim. Cosmochim. Acta. 58, 5627-5632.

Malhorta, V. M.; V. S. Ramachandran; R. F. Feldman; and P-C. Aïtcin. 1986. Condensed Silica Fume in Concrete. CRC Press, Boca Raton, Florida.

Malhotra, V. M., Ed.1989. "Fly Ash, Silica Fume, Slag, and Natural Pozzolans in Concrete." Proceedings of Third International Conference, 2, Trondheim, Norway, SP-114, American Concrete Institute, Farmington Hills, Mich., pp. 1579-1596.

Malhotra, V. M.; H. S. Wilson, and K. E. Painter. 1989. "Performance of Gravel-Stone Concrete Incorporating Silica Fume at Elevated Temperatures," in the Proceedings of the Third International Conference, Trondheim, Norway, 1989, Volume 2, pp. 1051-1076, ACI publication SP114-51.

Marine Engineering Organization. UK. 2004. "Corrosion Inhibitors ussed in Jacket Water System." http://www.marineengineering.org.uk/motjktwtr/motcorinhibMain.htm.

Mason, B. 1957. "Larnite, Scawtite and Hydrogrossular from Tokatoka, New Zealand." Amer.Mineral. 42, 379-392.

Massazza, F. 2004. Pozzolana and Pozzolanic Cements. Chapter 10, "Lea's Chemistry of Cement and Concrete." P.C. Hewlett, Ed., Elsevier, London.

Matthews A. and Y. Kolodny. 1978. "Oxygen Isotope Fractionation in De-carbonation MetamorphismMottled Zone Event." Earth and Planetary Science Letters 39 (1): 179-192.

Matthews A. and Y. Nathan. 1977. Decarbonation of Carbonate-Fluorapatite (francolite)." American Mineralogist 62 (5-6), pp. 565-573.

Matthews, A. and S. Gross.1980. "Petrologic evolution of the 'Mottled Zone' (Hatrurim) Metamorphic Complex in Israel.” Israel J. Earth Sci. 29, pp. 93-106.

Mattus C. H. and Gilliam T. M. 1994, A Literature Review of Mixed Waste Components: Sensitivities and Effects upon Solidification/Stabilization in Cement-Based Matrices. ORNL/TM-12656.

Mattus, C. H. and L. R. Dole. 2003. "Durability of Depleted Uranium Aggregates (DUAGG) in DUCRETE Shielding Applications," International High-Level Radioactive Waste Management Conference, Las Vegas, NV, USA, American Nuclear Society, La Grange Park, IL USA, 03/30/2003-04/02/2003. 
McConnell, J. D. C. 1954. "The Hydrated Calcium Silicates Riversideite, Tobermorite and Plombierite." Min. Mag. 30, pp. 293-305.

McConnell, J. D. C. 1955. "The Hydration of Larnite (b-Ca2SiO4) and Bredigite (aCa2SiO4) and the Properties of the Resulting Gelatinous Mineral Plomierite." Min. Mag. 30, pp. 672-680.

McConnell, J. D. C. 1960. "Vaterite from Ballycraigy, Larne, Northern Ireland.” Min. Mag. 32, pp. 534544.

McCreath and Kaiser. 1992. "Evaluation of Current Support Practices in Burst-Prone Ground and Preliminary Guidelines for Canadian Hardrock Mines," Rock Support in Mining and Underground Construction, International Symposium on Rock Support (Sudbury), Kaiser and McCreath (eds.), Balkema, Rotterdam, pp. 611-619.

McLaren, A. C.; J. D. Fitz-Gerald; and I. S. Williams. 1994. "The Microstructure of Zircon and its Influence on the Age Determination from $\mathrm{Pb}$ / U Isotopic Ratios Measured by Ion Microprobe." Geochimica et Cosmochimica Acta. 58, 2, pp. 993-1005.

Milodowski, A. E.; P. H .A. Nancarrow; and B. Spiro. 1989. A Mineralogical and Stable Isotope Study of Natural Analogs of Ordinary Portland Cement (OPC) and CaO-SiO2-H2O (CSH) Compounds. Nirex Report NSS/R240.

Moore, D. 1995. The Roman Pantheon: The Triumph of Concrete.

Moropoulou, A.; A. Bakolas, and S. Anagnostopoulou. 2004. "Composite Materials in Ancient Structures, Cement and Concrete Composites,", (in press).

Murdoch, J. 1955. "Bultfonteinite from Crestmore, California." Amer. Mineral. 40, 900-906.

Murdoch, J. 1961. "Crestmore, Past and Present.” Amer. Mineral. 46, pp. 245-257.

Nagy, G.; E. Draganits; A. Demeny; G. Panto; P. Arkai. 2002. "Genesis and Transformations of Monazite, Florencite and Rhabdophane During Medium Grade Metamorphism: Examples from the Sopron Hills, Eastern Alps." Chemical Geology. 191, 1-3, pp. 25-46

Naidu, M. G. and B. V. Covidarajulu. 1954. "Occurrence of Calciphyres Near Mallarajanahundi, Nanjangud (Mysore State)." Current Sci. 23, 10.

Neall, F. B. 1996. "Modelling the Long-Term Chemical Evolution of Cement-Groundwater Systems." In W.M. Murphy, D.A. Knecht (Eds.), Scientific Basis for Nuclear Waste Management XIX, MRS Symposia Proceedings, Vol. 412, Materials Research Society, Pittsburgh, PA, pp. 483- 490.

Nitao, John J.; and William E.Glassley. 1999. "Modeled Near-Field Environment Porosity Modification due to Coupled Thermohydrologic and Geochemical Processes. Materials Research Society Symposium - Proceedings, v 556, pp 705-711.

Oji, L. N. 2004. Condition Conducive to Forming Crystalline Uranyl Silicates in SRS Evaporators. WRSC-TR-2003-00553, Rev. 0.0, Westinghouse Savannah River Company, Aiken, SC.

Onofrei, M., and M. Gray.1988. "The Effect of W/C Ratio and Cement Type on the Longevity of Grouts for Use in Nuclear Fuel Waste Vaults." Proceedings of the Materials Research Society Symposium in Boston, Massachusetts, November 28-30, 1988. MRS Proceedings Volume 137, "Pore Structure and Permeability of Cementitious Materials." L. R. Roberts and J .P. Skalny, Eds., Materials Research Society, Pittsburgh, Pennsylvania, pp. 359-367, 1989.

Onofrei, M.; N.G. Malcom; L.D.Keil; and R. Pusch. 1989. "Studies of Cement and Grouting Techniques for Sealing a Nuclear Waste Disposal Vault." Proceedings of the Materials Research Society Symposium in Boston, Massachusetts, November 28-30, 1988. MRS Proceedings Volume 137, "Pore Structure and Permeability of Cementitious Materials." L.R. Roberts and J.P. Skalny, Eds., Materials Research Society, Pittsburgh, Pennsylvania, pp. 349-358, 1989.

Owens, B.E. 2000. "High-Temperature Contact Metamorphism of Calc-silicate Xenoliths in the Kiglapait Intrusion, Labrador." American Mineralogist. 85, 11-12, pp. 1595-1605.

Palmer, D. A.; P. Bénézeth; and D. J. Wesolowski. 2001. "Aqueous High Temperature Solubility Studies: The Solubility of Boehmite as a Function of Ionic Strength (to 5 molal, NaCl), Temperature (100$250^{\circ} \mathrm{C}$ ), and $\mathrm{pH}$ as Determined by In Situ Measurements," Geochim. Cosmochim Acta, 13, 20812095.

Palmer, D. A.; P. Bénézeth; and J. M. Simonson. 2004, “The Solubility of Copper Oxide 
Around the Water/Steam Cycle." PowerPlant Chemistry, 6(2), 81-87.

Palmer, D. A.; P. Bénézeth; D. J. Wesolowski; and L. M. Anovitz. 2002. "Impact of Nickel Oxide Solubility on Pressurized Water Reactor Fuel Deposit Chemistry," EPRI Report 1003155.

Parker, Harvey; Paul Godlewski; and Roberto Guardia. 2002. "The Art of Tunnel Rehabilitation with Shotcrete," Shotcrete, pp. 14 - 18, Fall.

Peterman, Z. E. and Cloke, P. L. 2002. Geochemistry of rock units at the potential Repository Level, Yucca Mountain, Nevada, Applied Geochemistry, v. 17, pp. 683-698.

Petit, J-C. 1992. "Natural Analogs for the Design and Performance Assessment of Radioactive Waste Forms: A Review." Journal of Geochemical Exploration 46, pp. 1-33.

Petit, J-C. 1992. "Reasoning by Analogy: Rational Foundation of Natural Analog Studies." Applied Geochemistry Supplementary Issue No. 1, pp. 9-11.

Petre-Lazar, L. Abdou, C. Franco, and I. Sadri. 2003. "THI - Model for Estimating the coupled Transport of Heat, Moisture, and Chloride Ions in Concrete." Proceedings of the 2nd International Workshop on Life Predication and Aging of Management of Concrete Structures. Paris, France, May 5-6, PRO 29, RILEM Bagneux, France, pp. 51-69.

Phan, L. T. et al. 2002. "High-Strength Concrete at High Temperature - An Overview," International Symposium on Utilization of High-Strength, High-Performance Concrete, June 16-20, Leipzig, Germany.

Pinheiro, S. M. de Mores, and M. R. Silva.2003, PRO 34, "Alteration of Concrete Microstructure by Biodeterioration Mechanisms." Proceedings of the International RILEM Conference on Microbial Impact on Building Materials, September 8- 9, 2003, Lisbon, Portugal. M.R. Silva, Ed. RILEM Publications, S.A.R.L., Bagneux, France, pp. 48-57.

Poitrasson, F.; S. Chenery; and T. J. Shepherd. 2000. "Electron Microprobe and LA-ICP-MS Study of Monazite Hydrothermal Alteration: Implications for U-Th-Pb Geochronology and Nuclear Ceramics." Geochimica et Cosmochimica Acta. 64, 19, pp. 3283-3297.

PQ Quartz. 2004. Bulletin 37-3, "PQ® Soluble Silicates: For Protection of Water Systems From Corrosion." P.O. Box 840, Valley Forge, PA 19482-0840.

Prikryl, James D.; Alka Jain; David R. Turner; Roberto; and T. Pabalan. 2001. "UraniumVI Sorption Behavior on Silicate Mineral Mixtures," Journal of Contaminant Hydrology, 47, pp. 241-253.

Ramachandran, V. S. 1984. Concrete Admixtures Handbook, Properties, Science and Technology. Noyes Publications, Park Ridge, NJ.

Rassineaux, F.; J-C. Petit; and A. Miunier. 1988. “Ancient Analogs of Modern Cement: Calcium Hydrosilicates in Mortars and Concretes from Gallo-Roman Thermal Baths of Western France." Journal of the American Ceramics Society 72 (6), pp. 1026-1032.

Ratcliffe, R. 1999. Scancem Materials (Australia) Pty Ltd, Osborne Park, WA, USA., "The Important Properties of Steel Fiber Reinforced Shotcrete (SFRS) Used in Mining," Publications of the Australian Institute of Mining and Metallurgy, 10th Australian Tunneling Conference 2/99, pp. 133-140.

Reverdatto, V. V. 1964. "Metamorphism in the Contacts of Anakit Trappean Massif in the Low Tunguska River, Materials on Genetic and Experimental Mineralogy." Akad. Nauk 2 97-169, SSSR, Novosibirsk.

Ridley, M. K.; M. L. Machesky; D. J. Wesolowski; and D. A. Palmer. 2004. "Modeling the Surface Complexation of Calcium at the Rutile-Water Interface to $250^{\circ} \mathrm{C}$," Geochim. Cosmochim. Acta, 68, 239-251.

Roberts, L. R. and J. P. Skalny, Eds. 1989. "Pore Structure and Permeability of Cementitious Materials." Proceedings of the Materials Research Society Symposium in Boston, Massachusetts, November 28-30, 1988. MRS Proceedings Volume 137, Materials Research Society, Pittsburgh, Pennsylvania, pp. 349- 358, 1989.

Rogers, R. D.; J. J. Knight; C. R. Cheeseman; J. H. Wolfram; M. Idachaba; K. Nyavor; and N. O. Egeibor. 2003. "Development of a Test Method for Assessing Microbial Influenced Degradation 
of Cement-Solidified Radioactive and Industrial Wastes." Cement and Concrete Research 33, pp. 2069-2076.

Ron H. and Y. Kolodny. 1992. "Paleomagnetic and Rock Magnetic Study of Combustion Metamorphic Rocks in Israel." Journal of Geophysical Research-Solid Earth 97 (B5), pp. 6927-6939

Rosato, V. G. and L. P. Traversa. 2000. "Lichen Growth on a Concrete Dam in a Rural Environment (Tandil Buenos Aires Province, Argentina).” PRO 20, Proceedings of the July 6-7, 2000, First International RILEM Workshop on Microbial Impacts on Building Materials, São Paulo, Brazil, Ed. R. Silva. RILEM Publications, S.A.R.L., Bagneux, France, No. 8, 2000.

Rosenberg, N. D.; G. E. Gdowski; and K .G. Knauss. 2001. "Evaporative Chemical Evolution of Natural Waters at Yucca Mountain, Nevada." Applied Geochemistry 16, pp. 1231-1240.

Roy, D. M. and B. E. Scheetz. 1992. "The Chemistry of Cementitious Systems for Waste Management: The Penn State Experience." Chapter 3, Chemistry and Microstructure of Solified Waste Forms, Ed. R.D. Spence, Lewis Publishers, Ann Arbor, MI, pp. 83-101.

Rubin, J. N.; C. D. Henry; and J. G. Price. 1993. "The Mobility of Zirconium and other 'Immobile' Elements during Hydrothermal Alteration." Chemical Geology. 110, 1-3, pp. 29-47.

Saito, Hiroshi and Akira Deguchi. 2000. "Leaching Tests on Different Mortars Using Accelerated Electrochemical Method." Cement and Concrete Research 30, pp. 1815-1825.

Saxena, S. K. 1966. "Evolution of Zircons in Sedimentary and Metamorphic Rocks." Sedimentology 6, 1, pp. $1-33$.

Shoesmith, D. W. 2000. "Fuel Corrosion Processes Under Waste Disposal Conditions," Journal of Nuclear Materials, 282, pp. 1-31.

Simmons, A. 2002. Natural Analogue Synthesis Report. TDR-NBS-GS-000027 REV00 ICN 02. Simmons, A. 2004. Natural Analogue Synthesis Report. TDR-NBS-GS-000027 REV00 ICN 04.

Sobolev, V. 1935. "A Rare Type of Contact Metamorphism of Limestones." Azp. Vses. Min. Obshch. 64, pp. 162-165.

Sonnenberg, E. L. and G.S. Bodvarsson. 1999. "Constraints on the Hydrology of the Unsaturated Zone at Yucca Mountain, Nevada from Three-Dimensional models of Chloride and Strontium Geochemistry." J. Contam. Hydrol. 38 (1-3), pp. 107-156.

Soroka, I. 1980. Portland Cement Paste and Concrete. Chapter 5, "Volume Changes in the Hardened Paste." Chemical Publishing Co., Inc., NY, pp. 102-144.

Sowder, A. G.; S. B. Clark; and R. A. Field. 1996. "The Effect of Silica and Phosphate on the Transformation of Schoepite to Becquerelite and Other Uranyl Phases." Radiochimica Acta 74, 45-49.

Spence, R. D., Ed. 1993. Chemistry and Microstructure of Solidified Waste Forms. Oak Ridge National Laboratory, Lewis Publishers.

Spence, R. D.; Bostick, W. D.; McDaniels, E. W.; Giliam, T. M.; Shoemaker, J. L.; Tallent, P. K.; Morgan, I. L.; Evans-Brown, B. S.; and Dodson, K. E. 1989. "Immobilization of Technectium in Blast Furnace Slag Grouts," Fly Ash, Silica Fume, Slag, and Natural Pozzolans in Concrete, Proceedings of Third International Conference, 2, Trondheim, Norway, SP-114, V. M. Malhotra, Ed., American Concrete Institute, Farmington Hills, Mich., pp. 1579-1596.

Spence, R. D.; T. M., Gilliam; I. Morgan; and S. C. Osborne. 1992. "Stabilization/Solidification of Wastes Containing Volatile Organic Compounds in Commercial Cementitious Waste Forms, Stabilization and Solidification of Hazardous, Radioactive, and Mixed Wastes." Vol. 2, ASTM STP 1123, T. M. Gilliam and C. C., Wiles, Eds., American Society for Testing and Materials, Philadelphia, pp. 61-72.

Steadman, J. A. 1986. "Archaeological Concretes as Analogs." Proceedings of the $2^{\text {nd }}$ NAWG Meeting, Interlaken, Switzerland, CEC Technical Report No. 1071 EN, CEC, Brussels, pp. 165-171.

Sun, W.; Y. Zhang; S. Liu; and Y. Zhang. 2004. "The Influence of Mineral Admixtures on Resistance to Corrosion of Steel Bars in Green High-Performance Concrete," Cement and Concrete Research, (in press).

Taylor, H.F.W. 1990. Cement Chemistry, Academic Press, London. 
Taylor, J. H. 1935. “A Contact Metamorphic Zone from the Little Belt Mountains, Montana.” American Mineralogist. 20, 2, pp. 120-128.

Temple, A. K. and E. W. Heinrich. 1964. “Spurrite from Northern Coahuila, Mexico.” Min. Mag. 33, pp. 841-852.

Tilley, C. E. 1929. "On Larnite (Calcium Orthosilicate, a New Mineral) and its Associated Minerals from the Limestone Contact Zone of Scawt Hill, County Antrim.” Min. Mag. 22, pp. 77-86.

Tilley, C. E. 1933. "Portlandite, a New Mineral from Scawt Hill, County Anrim." Min. Mag. 23, pp. 419420.

Tilley, C. E. 1942. “Tricalcium Silicate (Rankinite), a New Mineral from Scawt Hill.” Min. Mag. 26, pp. 190-196.

Tilley, C. E. 1947. “The Gabbro-Limestone contact Zone of Camas Mor, Muck, Inverness-shire.” Bull. Comm. Geol. Fin. 20, pp. 97-105.

Tilley, C.E. and H. F. Harwood. 1931. "The Dolerite-Chalk Contact at Scawt Hill, County Antrim.” Min. Mag. 22, pp. 439-468.

Tracy, R. J. and B. R. Frost. 1991. "Phase Equilibria and Thermobarometry of Calcareous, Ultramafic and Mafic Rocks, and Iron Formations." Reviews in Mineralogy. 26, pp. 207-289.

Trocellier, P. and E. Delmas. 2001. "Surface Chemistry of Weathered Zircons." Chemical Geology. 181, 1-4, pp. 13-22.

Walenta, K. 1968. Amer. Mineral. 69, pp. 408.

Wesolowski, D. J.; M. L. Machesky; D. A. Palmer; and L. M. Anovitz. 2000. "Magnetite Surface Charge Studies to $290^{\circ} \mathrm{C}$ from in situ pH Titrations." Chem. Geol. 167, 193-229.

Wood, K. 1981. Twenty Years of Experience with Slag Cement, Symposium on Slag Cement. University of Alabama, Birmingham.

Wright, F. E. 1908. "On the Contact Minerals from Velardena, Durango, Mexico (Gehlenite, Spurrite, Hillebrandite)." Amer. J. Sci. 26, p. 156.

Wronkiewicz, D.J.; J. K. Bates, S. F. Wolf, and E.C. Buck. 1996. J. Nucl. Mater. 238, 78.

Wu, X. and D. M. Roy. 1982. "Zeta Potential Investigation During Hydration of Slag Cement." Proceedings, M.R.S. Symposium, Boston, Research Society.

Wyatt, M. 1953. The Camansury (Skye) Gabbro-Limestone Contact. Part II of Ph.D. Thesis, Cambridge University.

Xue, S.; G. F. Herzog; A. Souzis; M. H. Ervin; R. T. Lareau; R. Middleton; J. Klein. 1995. "Stable Magnesium Isotopes, $\mathrm{Al}, \mathrm{Be}$, and $\mathrm{Mg} / \mathrm{Al}$ Exposure Ages of Iron Meteorites." Earth and Planetary Science Letters. 136, 3-4, pp. 397-406

Zadeh, M. S., G. Debicki, P. Clastres, and Y. Billard. 1998. "Influence of Silica Fumes on Permeability of Concrete to Oxygen for Temperatures up to $500^{\circ} \mathrm{C}$," in Sixth CANMET / ACI JCI International Conference, Volume 2, pp. 975-996; ACI SP 178-50. 


\section{APPENDIX A: LETTERS AND MESSAGES OF SUPPORT}



From: Larry Anovitz [anovitzIm@ORNL.GOV]

Sent: Tuesday, September 14, 2004 10:35 AM

To: Dole, Leslie Robert

Subject: Letter 4 - Alan Matthews- hebrew Univ. Jerusalem

>Date: Sun, 25 Jul 2004 15:35:41 +0300

>From: alan matthews <alan@vms.huji.ac.il>

>Subject: Hatrurim Samples

>To: anovitzlm@ORNL.GOV

$>\mathrm{X}$-Spam-Level :

$>$ X-OriginalArrivalTime: 25 Jul 2004 12:33:06.0671 (UTC)

$>$ FILETIME $=[89654 \mathrm{FF0}: 01 \mathrm{C} 47243]$

$>$

$>$ Dr Larry Anovitz

$>$ Oak Ridge National Laboratory, $>$ USA

$>$

$>$ Dear Larry,

$>$ In continuation of our previous communications, I will be pleased to >help you in any way that I can with the sampling of the Hatrurim

>formation for your proposed research project. I am well familiar with >the Hatrurim samples, having worked with my colleague Prof. Y.

>Kolodny on the petrology and stable isotopes of the metamorphic

>calc-silicates. We will be happy to take you to the sites that are

>best from the point of view of your study. There are no logistical

>problems that I know of in sampling or sending samples, but we will

>certainly be around to assist if any unforeseen problems were to crop $>$ up.

$>$ Yours sincerely.

$>$ Alan Matthews

$>$

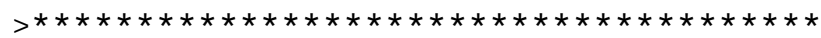

$>$ Alan Matthews, Professor and Chairperson Institute of Earth Sciences, $>$ Hebrew University of Jerusalem

$>91904$ Jerusalem

$>$ Israel

>Tel:(972) 26584230

$>$ mobile phone: 0523244538

$>$ Fax: (972) 25662581

>e-mail: alan@vms.huji.ac.il

$--$

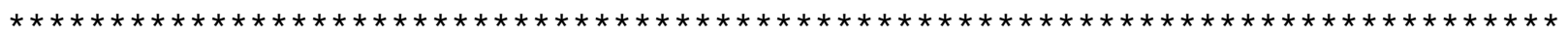

Dr. Lawrence M. Anovitz

MS 6110, PO Box 2008

Bldg. $4500-S$

Chemical Sciences Division

Oak Ridge National Laboratory

Oak Ridge, Tennessee 37831-6110

Phone: (865)-574-5034

Fax: (865) -574-4961

e-mail IZ9@ORNL.GOV

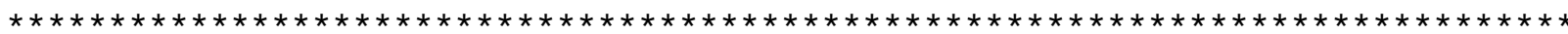




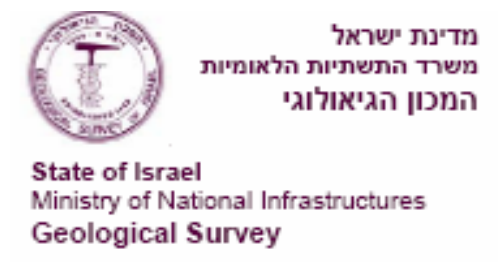

Dr. Lawrence M. Anovitz

MS 6110 , PO Box 2008, Bldg. 4500-S

Chemical Sciences Division

Oak Ridge National Laboratory

Oak Ridge. Tennessee $37831-6110$

August $1^{\text {1t }}, 2004$

Dear Dr. Anovitz,

This is to let you know that I will be happy to collaborate with you on your proposed work on the Hatruim rocks.

My experience with this "Mottled Zone" dates back to 1987 when I worked on this rock unit within the framework of my M.Sc thesis under the supervision of Prof. Y. Kolodny, Prof. A. Starinsky and Dr. Y. Bartov. My M.Sc. work concentrated on mapping and modeling of the high-T low-P metamorphic rocks exposed in some outcrops in Israel. The work included a detailed study of the mineral assemblages and their degree of metamorphism, and enabled for the first time to define four distinct metamorphic mapping units. The consequent mapping included detailed study of the relationship between the metamorphosed bodies and their parent rock (protolith). A method to map a metamorphic unit, which occurs within a sedimentary sequence, was thus developed. Consequently, I mapped the largest outcrop in Israel - the Hatrurim basin near the city of Arad. In addition, the duration of the combustion process at each site, its temperature and the age of metamorphism were determined. Integration of the data and the understanding of the phenomena led to the development of a model for the entire process, which includes ignition, combustion, cooling, and later retrograde metamorphism.

A detailed mapping of the Hatrurim rocks in other localities in Israel (Ma'ale Adumim, Nabi Musa, Jebel Harmun) was done later by me as part of my work in the Geological Survey of Israel.

Below are the references for two papers which summarize parts of the work.

With best regards

Avi Burg 
From: Larry Anovitz [anovitzIm@ORNL.GOV]

Sent: Tuesday, September 14, 2004 10:40 AM

To: Dole, Leslie Robert

Subject: Letter 5 - David Moore - Engineer working on roman concrete

>Date: Wed, 02 Jun 2004 19:05:41 -0400

>From: "John E. Moore" <moore.john.e@cox.net>

>Subject: Letter from my father

>X-Sender: moore.john.e@pop.east.cox.net

>To: lanovitz@utk.edu, anovitzlm@ORNL.GOV

$>\mathrm{X}$-OriginalArrivalTime: 02 Jun 2004 23:05:56.0984 (UTC)

$>$ FILETIME $=[29928780: 01 \mathrm{C} 448 \mathrm{~F} 6]$

$>$

$>$ Dr. Anovitz,

$>$ I will try again to send you the letter from my father. Two

>problems have been happening. One is that somehow, we got your email

>address wrong and an "i" was put in front of the "m" in anovitzlm

sinstead of an "el". That might have been a mistyping by my father.

$>$ With arial font, you can't tell the difference! The other problem is

>that his internet provider is going through an "upgrade" to prevent

>spam, and it is preventing him from sending any emails, even though he

$>$ is not sending spam.

$>$ so lets try it from my account.

$>$ Below is his letter.

$>$ Call or email if you have questions. Thanks, John Moore

$>703.385 .3367$ home

$>703.869 .1326 \mathrm{cell}$

$>3161$ Canyon Rim Lane

>Salt Laker City, Utah 84109

$>$

$>23$ May 2004

$>$

$>$ Dr. Lawence M. Anovitz

$>$ MS 6110, PO box 2008

$>$ Bldg. $4500-S$

>Chemical Sciences Division

>Oak Ridge National Laboratory

>Oak Ridge, Tennessee 37831

$>$

$>$ Dear Dr. Anovitz:

$>$

$>$ At your request, I am submitting a brief of my qualifications for pproviding submittals in the investigation of a review of the technical >processes of ancient Roman concrete to study the elements of high >silica cements. This effort should prove valuable in developing a high >quality cement especially tailored to produce special encasements at $>$ Yucca Mountain for the Laboratory.

$>$

$>$ My educational alignment is with the civil engineering profession; my >degrees are from Utah State University (BS), University of Utah (MS), >and Stanford University (PE). My work in this field covers a lifetime >of experience (45 years) in design and construction of large projects >such as dams, hydraulic works, airfields, highway structures, various >buildings, and missile system engineering. I have been a supervisor in >the prestigious consulting engineering firm of International 


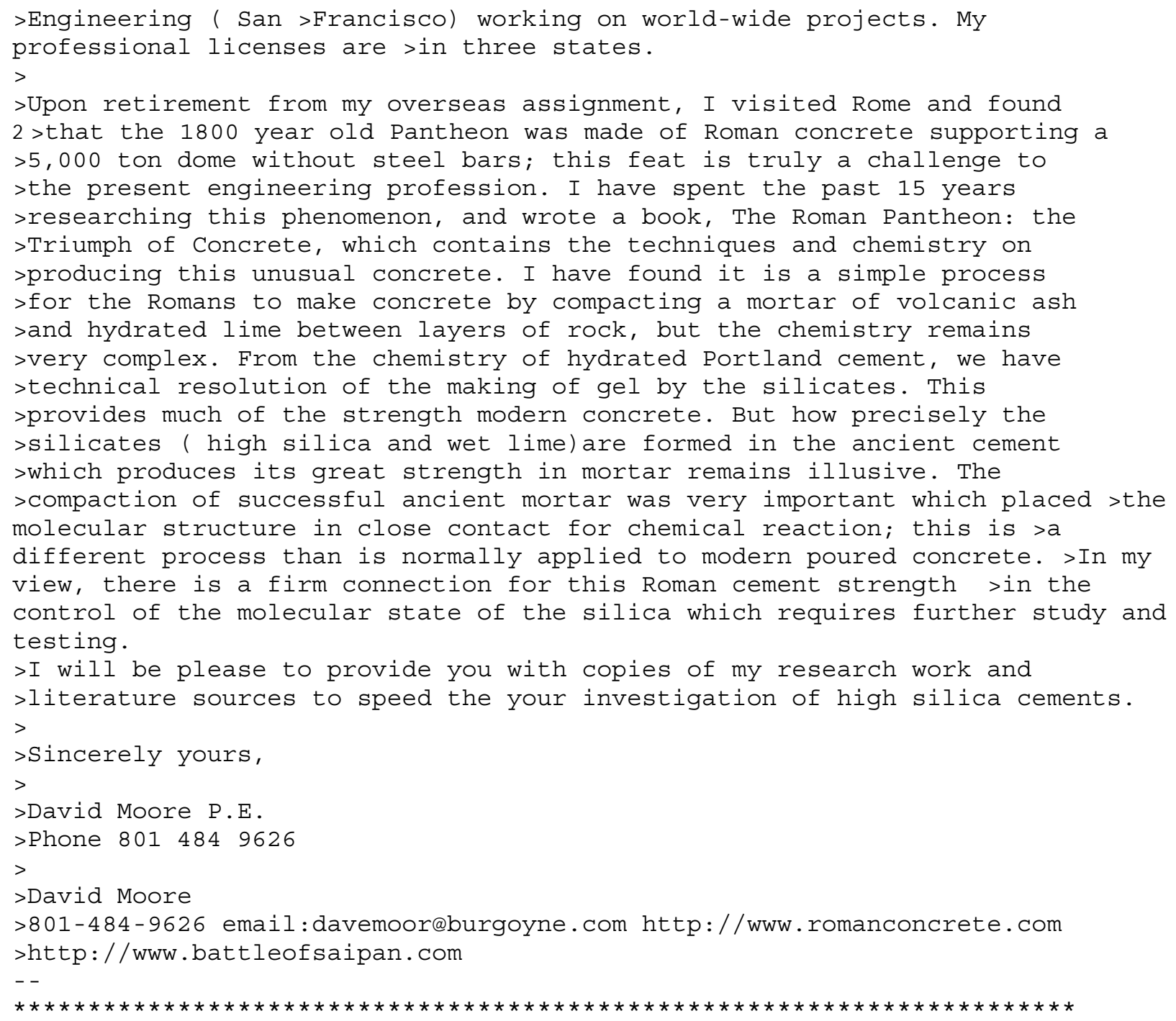




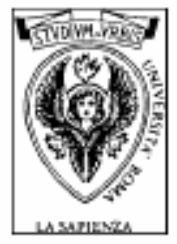

\author{
Università degli Studi di Roma "La Sapienza" \\ Dipartimento di Ingegneria Strutturale e Geotecnica \\ Via Eudossiana, 18 - 00184 Roma
}

il direttore

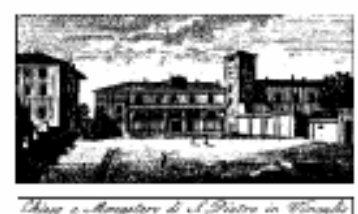

Dr. Lawrence M. Anovitz

MS 6110 , PO Box 2008

Bldg. 4500-S

Chemical Sciences Division

Oak Ridge National Laboratory

Oak Ridge, Tennessee 37831-6110

Dear Dr. Anovitz,

following our e-mail contacts, in my quality of Professor and Head of the Department of Structural and Geotechnical Engineering of the University of Rome "La Sapienza", I am pleased to inform you that we have, in our material Laboratory, some samples of ancient roman concrete that we can share with Oak Ridge National Laboratories for your Research needs,

The samples come from the Basilica of Massenzio and from the Harbour of Ostia Antica (the ancient harbour of Rome on the sea), which structures were studied in previous researches.

Our Department has a considerable experience in the study of ancient Roman structures, obtained in years of analysis and restoration of the most important monuments of Rome. All the projects involving ancient Monuments are under the supervision of the National Cultural Heritage Authority and any sampling will be executed after their permit. Such studies are in continuous development and we can try to help to get other useful samples in the future.

Please feel free to ask me for any further detail.

Best Regards

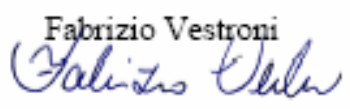

Fabrizio Vestroni

Professor and Head

Dip. di Ingegneria Strutturale e Geotecuica, Università di Roma "La Sapienza"

Via Eudossiana 18, 00184 Roma, Tel. 06-4458 5198, Fax 06-488 4852

email : vestroni $a$ uniromal it 


\section{האגיברסיטה העברית בירושלים}

THE HEBREW UNIVERSITY OF JERUSALEM Institute of Earth Sciences

Yehoshua Kolodny

Leo Picard Professor of Geology

kolodny@vms.huji.ac.il

Tel: (972)-2-6584 685

Fax: (972)2-5662581

Dr. Lawrence M. Anovitz

MS 6110, PO Box 2008

B1dg. 4500-S

Chemical Sciences Division

Oak Ridge National Laboratory

Oak Ridge, Tennessee 37831-6110

Dear Larry,

I was most pleased to receive your suggestion of cooperation on the study of the Hatrurim Formation (Mottled Zone) assemblage as a natural analogue of radioactive waste disposal into Portland Cement related man-made environments. As you well know I have been involved for many years in the study of this exciting rock assemblage from numerous aspects: geological, mineralogical, geochemical. I will be more than pleased to cooperate with you and your group in any possible way: take you to the best localities we know, show you our rather extensive rock and mineral collection, share with you any old samples we collected that you might find critical. I do not foresee any problem in collecting samples in Israel and taking them to the US. Neither do I expect any problem in going out to the field: almost all good Hatrurim exposures are within Israel proper (West of the "Green Line"), and pose no security problem in visiting them.

I look forward to a fruitful cooperation, and wish you much success with the project Sincerely

Yehoshua 
APPENDIX B: NATURAL ANALOG SITE DETAILED DESCRIPTIONS 



\section{Marble Canyon, West Texas}

Marble Canyon is a box canyon on the eastern rim of the Sierra Diablo plateau, Culberson County, west Texas. It is located north of the town of Van Horn and is reached from State Highway 54. The regional and local geology around Marble Canyon have been described by Bridge (1966a, 1966b, 1980, 1986), Gregg and Sibley (1984), Price and Henry (1986), Henry and Price (1986), and Price et al. (1986), and their discussions are summarized here. The canyon is elongate, approximately $1.5 \mathrm{~km}$ long and $1 \mathrm{~km}$ wide. Exposures of the Permian Hueco and Bone Springs formations are intruded by a zoned Tertiary pluton (Sharp 1979). Where the contact of the intrusion with the surrounding marbles is exposed, it is nearly vertical (King 1965). The country rocks appear to have been only slightly deformed by the intrusion, as they dip away from it at the south end, and towards it on the north (Price and Henry 1986).

The Hueco Formation in Marble Canyon is approximately $270 \mathrm{~m}$ thick and in this area is nearly pure dolomite. Unmetamorphosed, it is relatively permeable, containing intercrystalline and fossil moldic porosity. The northeast section of the intrusion is in the Hueco, while the rest of the contact zone is in the Bone Springs Formation. The metamorphosed Hueco is currently being mined underground for architectural aggregate and for use in dry-wall products, stuccos, plaster, paints, and plastics (Price and Henry 1986; Williams, personal communication).

The Bone Springs Formation is approximately $740 \mathrm{~m}$ thick and consists of interbedded dolomitic limestone and cherty fossiliferous limestone and is locally interbedded with thin shales. Most of the hightemperature calc-silicate phases at Marble Canyon occur in metamorphosed Bone Springs Formation. The intrusion itself is roughly elliptical in shape, is approximately $1400 \mathrm{~m}$ long and $300 \mathrm{~m}$ wide, and is zoned from a rim of nepheline-bearing alkali gabbro to a quartz syenite core. Reconstruction of the regional stratigraphy constrains the present top of the intrusion to a lithostratigraphic pressure of approximately 370 bars at the time of intrusion (Price et al. 1986). This was based on mapping by King (1965) of $550 \mathrm{~m}$ of later Permian rocks above the intrusion in the canyon, a reconstruction of $770 \mathrm{~m}$ of Cretaceous cover, and $120 \mathrm{~m}$ of Tertiary volcanic and volcanoclastic cover. The composition and nature of this intrusion are well known (Kuehn 1969, Price et al. 1986).

On the peak to the north near the mouth of Marble Canyon sits a second, smaller igneous body, the Cave Peak intrusion. This body contains a molybdenum prospect, and has been extensively drilled. It appears to be a later phase of the same intrusive event that formed the Marble Canyon intrusion. It is rhyolitic and contains abundant fragments that appear lithologically similar to the Marble Canyon body (Sharp 1979). K-Ar dating of the Marble Canyon and Cave Peak intrusions range from 34 to 37 m.y., with one additional result of 39.5 m.y. on a questionable sample (Sharp 1979, Price and Henry 1986). The Marble Canyon intrusion appears to be slightly the older of the two, although the uncertainties are too large to prove this. The Cave Peak intrusion is sufficiently distant from the Marble Canyon intrusion $(\sim 1 \mathrm{~km})$ that its effects on the Marble Canyon metamorphism are likely to be minor.

The Marble Canyon Stock is surrounded by a well-defined contact aureole approximately $180 \mathrm{~m}$ wide. This limit, mapped by Bridge (1966a), was defined underground in the Hueco Formation by a transition from a white to a grey marble, and in the Bone Springs Formation by the occurrence of black, fossiliferous, somewhat fetid limestone. It is the mineralogy of this contact aureole that makes the Marble Canyon area truly spectacular, as it was the first location in the United States in which the entire sequence of metamorphic minerals predicted by Tilley (1923) and Bowen (1940) for calc-silicates was described (Bridge 1966a, 1966b, 1980, 1986). Marble Canyon is unusual in that it contains a number of very high temperature phases. In addition, Bridge (1966a, 1966b) reported the presence of three of the $\mathrm{Ca}_{2} \mathrm{SiO}_{4}$ polymorphs, including the as-yet-unnamed phase $\mathrm{Ca}_{2} \mathrm{SiO}_{4}$ (informally known as shannonite) for which

Marble Canyon is the only known location where it occurs worldwide. It is this mineral assemblage that makes Marble Canyon an excellent location for an analog study of weathering of high-silica cements. 


\section{HUECO LIMESTONE}

The Hueco Formation in Marble Canyon has been metamorphosed to white marble. Approximately 125 $\mathrm{m}$ from the contact, the marble changes from grey to white. The distal edge of the grey marble has not been mapped. Previous workers (Bridge 1966a, 1980, 1986) have interpreted the grey to white transition as the edge of metamorphism. The presence of very small amounts of humites and olivine in the grey marble, however, suggests that these rocks have not remained completely unmetamorphosed. The grey limestone consists primarily of calcite, dolomite, and brucite after periclase. Quartz is not present. The white primarily consists of calcite and periclase. All of the dolomite in the white marble occurs in veins or as a secondary alteration. The compositions of several of the secondary dolomites are unusual, being either calcian or magnesian. This may suggest the presence of fine-grained intergrowths of calcite and/or other $\mathrm{Ca}-\mathrm{Mg}$ carbonates such as huntite. As quartz is not present in the grey marble, the color boundary appears to represent the isograd for the reaction:

$$
\text { Dolomite }=\text { Calcite }+ \text { Periclase }+\mathrm{CO}_{2}
$$

The width of the dolomite-calcite-periclase zone is unknown because mining operations stop at the white/grey marble contact.

With the exception of phases found in a small skarns of uncertain thickness (probably $<2 \mathrm{~m}$ ) between the Hueco marble and the intrusion, and in the marble within less than $0.5 \mathrm{~m}$ of the skarn, small amounts of humites, forsterite, and secondary serpentine are usually the only silicates in these rocks, although quartz has been found in some samples lacking humites and forsterite.

\section{BONE SPRINGS LIMESTONE}

The mineralogy of the metamorphosed Bone Springs Formation is significantly different from that of the Hueco Formation, and it is this formation that is of primary interest for the analog study proposed here. The Bone Springs is a much siltier limestone, with a greater initial porosity. This resulted in the formation of a number of contact metamorphic assemblages, including many of the very high-temperature calcsilicates.

Distal samples of the Bone Springs, collected at distances up to $100 \mathrm{~m}$ from the contact, appear in hand specimens to be unmetamorphosed, black to grey, fossiliferous, slightly fetid limestone. In thin section some recrystallization can be seen, but fossils such as fusilinids and crinoids are still evident. Mineralogically the samples consist primarily of a low-magnesian calcite and dolomite. Calcites commonly contain several mole percent $\mathrm{MgCO}_{3}$ and $\mathrm{FeCO}_{3}$. Many of the samples contain observable organic matter, which accounts for their dark color. As with the Hueco Formation, small amounts of metamorphic minerals, including humites, brucite after periclase, forsterite, geikelite, sphene and rutile are found in even the least-altered samples.

Wollastonite, occasionally coexisting with both calcite and quartz, becomes common nearer the contact. Diopside is also common in these assemblages, and spinel occurs in some samples. Primary talc and tremolite, the lower temperature phases of Bowen's decarbonation series, have not been found, although small amounts of secondary talc do occur. Barite, anhydrite and/or phlogopite or an aluminous biotite are occasionally found in this zone. Texturally, the assemblage wollastonite \pm calcite \pm quartz \pm diopside occurs both as a fine intergrowth of $<0.1 \mathrm{~mm}$ phases, and as larger grains up to $1 \mathrm{~mm}$ across. These phases are commonly intergrown and in contact and appear in textural equilibrium. In some cases, calcite appears to occur as an interstitial phase between quartz grains. Wollastonite is occasionally found as small inclusions in larger calcite aggregates although in other parts of the same thin section it occurs as larger grains coexisting with quartz and/or calcite. Diopside commonly occurs as smaller, rounded grains as 
inclusions and along the boundaries of the other phases. Calcite in these assemblages is generally nearly end-member $\mathrm{CaCO}_{3}$ - the $\mathrm{MgCO}_{3}$ content of the lower-grade material apparently having reacted out in the absence of dolomite. Sphene and rutile found in more distal samples are replaced by perovskite in this zone.

The assemblage wollastonite \pm calcite \pm quartz \pm diopside give way fairly abruptly to samples containing higher temperature phases including melilite, monticellite, merwinite, rankinite, spurrite, and the $\mathrm{Ca}_{2} \mathrm{SiO}_{4}$ phases near the contact. The position of this break relative to the contact is variable, occurring as close as $3 \mathrm{~m}$ and as far as $23 \mathrm{~m}$ from the intrusion. These samples are generally much coarser grained than those in the calcite - wollastonite zone, with grain sizes up to $1 \mathrm{~mm}$. In hand samples, these phases are usually difficult to distinguish, as even samples consisting almost entirely of monticellite appear as massive grey rock.

Most of the higher-temperature phases have compositions that are close to end-member. The most common exception is the melilite-grains that are commonly zoned, with gehlenite-rich cores and akermanite-rich rims. Larger grains are occasionally more strongly zoned than the smaller ones in the same thin section, suggesting that either they formed earlier or the smaller grains were not cut near the center. In many grains, the zoning is optically apparent. Zoning profiles through this core region suggest that it represents a sharp compositional break. This may reflect a change in the melilite-forming reaction during the growth of these grains and suggests that they may be useful for describing T-X $\left(\mathrm{CO}_{2}-\mathrm{H}_{2} \mathrm{O}\right)$ paths that are followed during metamorphism. This possibility will be explored in greater detail in future research. Occasionally, monticellite samples also yield non-end-member compositions. These samples are iron-bearing and somewhat subcalcic and may co-exist with forsterite.

Garnets are also found near the contact. These are commonly zoned andradite-grossular garnets, with grossular-rich cores and andradite-rich rims. The zoning is often visible in thin section because the garnets often have yellow cores and clear rims. Backscattered electron imaging also shows the zoning clearly, and cross-sectional analysis shows that some of these grains contain several compositional zones. Garnets rich in $\mathrm{Ti}$ and $\mathrm{Cr}$ also occur at Marble Canyon. Some are very chromian. Most garnets analyzed, however, have relatively low $\mathrm{Ti}$ and $\mathrm{Cr}$ contents. Garnets are commonly, but not always, anisotropic and often show sector zoning. Many of the anisotropic samples are Si-deficient, yield microprobe totals that are 1-5 wt \% low, and may have a significant hydrogarnet component. Some garnets appear to be overgrowths on other phases and thus may have formed late, while others appear primary.

Fluorine-bearing minerals are common at Marble Canyon. Cuspidine $\left(\mathrm{Ca}_{4} \mathrm{Si}_{2} \mathrm{O}_{7} \mathrm{~F}_{2}\right)$ is a common phase in both the samples from near the contact and in the wollastonite \pm calcite \pm quartz \pm diopside assemblages. Texturally it appears primary, occurring in contact with a variety of other calc-silicate minerals. Phlogopite is also commonly fluorine- rich, as is apatite. Humites are also found in both the Bone Springs and Hueco Formations, usually in distal rocks with an otherwise simpler calcite \pm dolomite \pm quartz mineralogy.

Apatite group minerals at Marble Canyon are unusual as they often contain a high percentage of fluoroellestadite $\left(\mathrm{Ca}_{5}\left(\mathrm{SiO}_{4}, \mathrm{SO}_{4}\right)(\mathrm{F}, \mathrm{OH}, \mathrm{Cl})\right)$. Some samples are nearly end-member. There is a tendency for the ellestadite concentration in apatite to be higher near the contact, as apatites in distal rocks seldom contain a large component.

Perovskite is the most common oxide phase found in the Bone Springs marble. Grains vary from $10 \mu \mathrm{m}$ to $0.5 \mathrm{~mm}$ in diameter, are dark brown in color, and large grains are commonly twinned. Rutile occurs in distal samples, as does brucite after periclase. Spinel occurs in samples from near the contact. This is 
dominantly $\mathrm{MgAl}_{2} \mathrm{O}_{4}$, but usually contains some hercynite component and traces of $\mathrm{Ti}$ and $\mathrm{Cr}$. Geikelite, hematite, magnetite, and Ti-magnetite grains are occasionally observed, but all are rare.

A wide array of alteration phases are found in the Bone Springs Formation. Pectolite commonly occurs as radiating sprays up to several milimeters long, and chlorite occurs in a number of samples. Hydrotalcite $\left(\mathrm{Mg}_{6} \mathrm{Al}_{2}\left(\mathrm{CO}_{3}\right)(\mathrm{OH})_{16^{\bullet}} 4 \mathrm{H}_{2} \mathrm{O}\right)$ occurs occasionally as an alteration of spinel. Brucite occurs commonly in the Hueco Formation and occasionally in the Bone Springs as a pseudomorph after periclase. Serpentine is also common, sometimes with relict forsterite or humite. Identification of many of the alteration phases is made difficult by their fine-grained, intergrown habit, and because a number of phases have similar compositions. Tentative phase identifications were made from microprobe analyses that yielded cation ratios and an estimate of the water content from the oxide totals, but many of these phases can only be identified as one of a group of minerals in this manner. These include okenite or gyrolite or nekoite, and heulandite or stilbite, and other hydrous calc-silicate phases including afwillite (and/or foshallasite), rosenhahnite (and/or scawtite or xonotlite), foshagite, fukalite (and/or hillebrandite), and possibly tobermorite occur in numerous samples. Calcite occasionally also occurs as a secondary phase. Secondary calcite occurs either in veins, or on grain boundaries.

\section{Christmas Mountains, West Texas}

The Christmas Mountains (discussion based on Joesten 1974), an elliptical dome of Cretaceous carbonate rocks which dip radially away from a core of intrusive gabbro and syenite, lie along the northwest border of the Big Bend National Park in west Texas. Cross-cutting relationships indicate that rocks of the gabbro complex are the oldest of a series of intrusive and extrusive igneous rocks of Early Tertiary age in the western part of the range (Bloomer, Ms. in progress; Swadley, Ms. in progress; Jenkins, Ms. in progress).

Nodules of rusty-weathering, calcareous chert are sparsely distributed throughout the Lower Cretaceous Del Carmen and Santa Elena Limestones in the Christmas Mountains. Although nodular chert generally is a trace constituent in the stratigraphic section, at some horizons it makes up as much as $20 \%$ of the rock. Nodules from one such horizon, exposed at an elevation of $1370 \mathrm{~m}$ along the crest of the flat-topped ridge that forms the south wall at the mouth of Mud Springs Draw, were sampled at closely spaced intervals along a $120 \mathrm{~m}$ traverse, normal to the contact with the Christmas Mountain gabbro, which dips $70^{\circ}$ beneath the limestone at this location. The total thickness of strata, from the base of the Sue Peaks formation to the top of the Cretaceous section, is $1345 \mathrm{~m}$ (Bloomer, Ms. in progress; Joesten, Ms. in progress; Maxwell et al. 1967), thus the sampled horizon was overlain by, at most, $1230 \mathrm{~m}$ of rock at the time of gabbro emplacement. The lithostatic pressure at this depth is 325 bars, if an average rock density of $2.7 \mathrm{~g} / \mathrm{cm}^{3}$ is assumed.

As the gabbro contact is approached, a series of changes takes place both in the shape and mineralogy of the chert nodules as a result of reaction between chert and limestone. In the unmetamorphosed limestone, chert nodules range in shape from equidimensional to very irregular, branching forms. When the chert recrystallized to quartz or reacted with the enclosing limestone to form concentric shells of calc-silicate minerals, morphological irregularities were smoothed out. The resulting nodules are spherical or ellipsoidal.

Perhaps the most striking feature of the nodules is the change from homogeneous, aphanitic chert to concentrically zoned nodules of coarse-grained, talc-silicate minerals. In addition to wollastonite, which forms the core of the nodules, and calcite, which forms the rim, individual talc-silicate nodules may contain rankinite, spurrite, and tilleyite. The phases present in a given nodule are a function of the distance from the intrusive contact and reflect, in a general way, the thermal history of that point in the aureole. The calc-silicate minerals are distributed in concentric one- and two-phase shells, separated from one another by sharp contacts. The sequence of mineral assemblages across a nodule results in a radial 
compositional gradient along which the ratio of $\mathrm{CaO}$ to $\mathrm{SiO}$ increases in steps from the core of the nodule to its rim.

Mineral assemblages in the chert and calc-silicate nodules are listed in Table B.1. The assemblages, as listed from left to right, correspond to the sequence of zones from the rim of the nodule to the core. Zone boundaries commonly are quite sharp and smoothly curving in three dimensions. There is a marked tendency for one-phase assemblages to occur, but two- and, rarely, three-phase assemblages are found within $18 \mathrm{~m}$ of the gabbro. 
Table B.1. Assemblages in Christmas Mountain nodules

\begin{tabular}{|c|c|c|c|c|c|c|c|c|c|c|}
\hline Sample & $\begin{array}{l}\text { Distance } \\
\text { (meters) }\end{array}$ & $\mathbf{C}$ & $\mathbf{C}+\mathbf{T}$ & $\mathbf{T}$ & $\mathbf{T}+\mathbf{S}$ & $\mathbf{T}+\mathbf{R}$ & $\mathbf{T}+\mathbf{W}$ & $\mathbf{R}+\mathbf{W}$ & $\mathbf{W}$ & $\overline{\mathbf{Q}}$ \\
\hline$\overline{\mathrm{CM}}-152$ & 4.6 & $\mathrm{X}$ & $\mathrm{X}$ & & & $X$ & $\mathrm{X}$ & $\mathrm{X}$ & $\mathrm{X}$ & \\
\hline CM-153 & 5.5 & $X$ & $X$ & & & $X$ & $X$ & & $X$ & \\
\hline CM-154 & 7.9 & $X$ & $X$ & $X$ & $\mathrm{X}$ & $X$ & & $X$ & $X$ & \\
\hline CM-155 & 11.3 & $X$ & $X$ & & & $X$ & $X$ & & $X$ & \\
\hline CM-156A & 15.0 & $X$ & & & $\mathrm{X}$ & $X$ & $X$ & $X$ & $X$ & \\
\hline CM-156B & 15.2 & $X$ & & $X$ & & & $X$ & & $X$ & \\
\hline CM-124-1 & 15 & $X$ & $X$ & $X$ & & $X$ & $X$ & & $X$ & \\
\hline CM-124-2 & 15 & $X$ & & $X$ & & $X$ & $X$ & & $X$ & \\
\hline CM-157 & 18.3 & $X$ & & $X$ & & & $X$ & & $X$ & \\
\hline CM-158 & 22.0 & $X$ & & $X$ & & & & & $X$ & \\
\hline CM-159 & 26.2 & $X$ & & $X$ & & & & & $X$ & \\
\hline CM-160 & 29.6 & $X$ & & $X$ & & & & & $X$ & \\
\hline CM-161 & 82.4 & $X$ & & & & & & & $X$ & \\
\hline CM-163 & 35.7 & $X$ & & & & & & & $X$ & \\
\hline CM-163 & 38.8 & $X$ & & & & & & & $X$ & \\
\hline CM-131 & 59.5 & $X$ & & & & & & & $\mathrm{X}$ & \\
\hline CM-1655 & 83.9 & $X$ & & & & & & & & $X$ \\
\hline CM-129 & 122 & $X$ & & & & & & & & $X$ \\
\hline
\end{tabular}

Chert nodules from unmetamorphosed limestone consist of microcrystalline silica and calcite. Calcite occurs in irregular patches of granular grains and as microfossils. Although it is not uniformly distributed within a nodule, calcite generally makes up about $10 \%$ of its volume. Contacts between chert and enclosing limestone are sharp. In the interval of 70 to $100 \mathrm{~m}$ from the gabbro, microcrystalline silica has been recrystallized to a xenoblastic aggregate of quartz.

Nodules collected between 30 and $60 \mathrm{~m}$ from the gabbro-marble contact consist entirely of fine- to very coarse-grained, prismatic wollastonite. The contact between the wollastonite nodule and enclosing calcite marble is sharp. Wollastonite and quartz have not been found intergrown, and quartz does not form the core of any wollastonite-bearing nodule.

Nodules collected between 18 and $30 \mathrm{~m}$ from the contact have a core of coarse, prismatic wollastonite separated from marble by a rim of granoblastic tilleyite, 0.5 to $1 \mathrm{~cm}$ in width. In most of the nodules from this interval, tilleyite is nearly completely replaced by fibrous scawtite, but irregular relicts of fresh tilleyite confirm its presence in this zone. Apart from this fibrous alteration of tilleyite, calcite, tilleyite, and wollastonite occur in well-defined, monomineralic zones. There are no incompatable phases in contact across zone boundaries. That is, calcite and wollastonite are never found in mutual contact. 
Calc-silicate nodules collected within $16 \mathrm{~m}$ of the gabbro contain calcite, tilleyite, rankinite, wollastonite, and, in some cases, spurrite. Calcite, tilleyite, and wollastonite form monomineralic zones as before, but spurrite and rankinite occur exclusively in two- and three-phase assemblages with tilleyite or wollastonite. One- and two-phase assemblages form distinct zones in the talc-silicate nodules, but three-phase assemblages usually consist of isolated grains of the third phase within a two-phase zone. For example, the observed three-phase assemblages, tilleyitespurrite-rankinite and tilleyite-rankinite-wollastonite, consist of scattered single grains of spurrite or wollastonite in zones consisting mainly of tilleyite and rankinite.

Nodules collected within $16 \mathrm{~m}$ of the intrusive contact differ from the other calc-silicate nodules in two important respects. The first is the abrupt appearance, in a single nodule, of two new phases-spurrite and rankinite - as contrasted with the appearance of a single, new phase each of the other calc-silicate zones. The second is the restriction of spurrite and rankinite to two- and three-phase assemblages, which is a significant departure from the pattern of monomineralic assemblages characteristic of calc-silicate nodules from the outer part of the aureole.

The inferred sequence of prograde reaction zones is

1. calcite-quartz

2. calcite-wollastonite

3. calcite-tilleyite-wollastonite

4. calcite-tilleyite-spurrite-rankinite-wollastonite

5. calcite-spurrite-rankinite-wollastonite

Each set of phases differs from its neighbor by the appearance, or disappearance of a single phase, except for spurrite and rankinite, which appear together at $18 \mathrm{~m}$. The question naturally arises as to whether spurrite and rankinite resulted from a single reaction or from two separate reactions' If the latter were the case, the order in which they formed with increasing temperature may yield information that would place limits on the pressure and fluid phase composition during metamorphism.

\section{HATRURIM Formation (MOTTLED ZONE), ISRAEL}

The Hatrurim Formation, originally described as the Mottled Zone Complex (Picard 1931, Bentor 1960) is a classic example of what is known as "combustion metamorphism" - metamorphism caused by something, usually a coal bed, that has caught on fire. The metamorphism of this deposit has been described by a number of authors, including Avnimelech (1965, in a review of earlier work), Picard (1931), Bentor (1960), Bentor and Vroman (1960), Bentor et al. (1963a,b, 1981), Gvirtzman and Buchbinder (1966), Gross et al. (1967), Gross (1970), Bentor et al. (1972) Kolodny and Gross (1974), Gross (1977) (the description below has largely been taken, with some modifications, from this source), Matthews and Nathan (1977), Matthews and Kolodny (1978) Matthews and Gross (1980), Kolodny et al. (1973), Ron and Kolodney (1992), and Gur et al. (1995).

In many parts of Israel, a sequence of slightly phosphatic chalks and marls of the Ghareb Formation (Upper Campanian to Maastrichtian age) and clays and marls of the Taqiye Formation (Dano-Paleocene Age), are found overlying flint and phosphorite beds of the Mishash Formation (Campanian age). In many outcrops and in subsurface sections, these rocks are bituminous. The lower part of the Ghareb Formation may contain up to $26 \%$ organic matter and can be classified as oil shales (Shahar and Würzburger 1967).

In a number of areas, an entirely different, thermally metamorphosed facies, the so-called Hatrurim Formation or Mottled Zone appears instead of the normal sequence. These rocks in the Jerusalem-Jericho area attracted the attention of numerous geologists as early as the middle of the nineteenth century. The 
name "Mottled Zone" was proposed by Picared (1931), who described its outcrops in the Ma'ale Adumim and at Nebi Musa. The term "mottled" refers to the vivid, variegated colors of the rocks.

At least nine, widely separate outcrops are known: the Hatrurim syncline west of the Dead Sea, Ma'aleh Adumim, Beit Sahur, Nebi Musa and Jebel Harmun in the Judean Desert, Nahal Ayalon in the Coastal Plain, Kefar Uriyya and Tarqumiye in the Shefela region (western foothills), and Nahal Malhata in the Be'er Sheva' Valley in the northern Negev (of these four and possibly five fall within the boundaries of pre-1967 Israel and can currently be visited in relative safety, including the major outcrop in the Hatrurim syncline). In its fully developed occurrence in the Hatrurim syncline, the complex has a preserved thickness of more than $220 \mathrm{~nm}$ and covers an area of $50 \mathrm{~km}^{2}$. The complex includes the rock-teime equivalents of the Ghareb, Taquie, and possibly Zor'a formations and relicts of the Hazeva Formation.

The Hatrurim formation has a very complex mineralogy and is composed largely of uncommon hightemperature minerals characteristic of contact metamorphosed calc-silicates. In all other localities these assemblages were found in narrow aureoles immediately adjacent to near-surface intrusion or in limestone xenoliths within basalts. The Hatrurim Formation is, however, unique in that, unlike the other sanidinite-facies localities, it could not have formed by contact metamorphism, as no igneous rocks have been found associated with it except for a small dike reported at Tarqumiye. While there were a number of early suggestions as to the origin of the Hatrurim Formation, Bentor and Vroman (1960) were the first to suggest a high-temperature origin for these rocks in which spontaneous combustion of bituminous matter was the heat source, and Bentor et al. (1963a,b) provided the first evidence for high-temperatures based on the presence of high-temperature minerals such as spurrite, gehlienite, and brownmillerite. This was confirmed isotopically by Bentor et al. (1972) and Kolodny and Gross (1974).

There have been two attempts to date the metamorphism. Kolodny et al. (1973) dated the latest thermal event at 13.6 or $16.8 \mathrm{Ma}$ on the basis of fission-track dating. Gur et al. (1995) re-evaluated the age of the metamorphic events using ${ }^{40} \mathrm{Ar} /{ }^{39} \mathrm{Ar}$ plateau and isochron ages Their results indicated a major combustion metamorphic event around $3 \mathrm{Ma}$, probably preceded by an event around $16 \mathrm{Ma}$. They concluded that the early event took place upon initial exposure of the protolith in the Miocene, whereas the second followed the removal of Neogene sediments and re-exposure of the bituminous rocks.

Gross (1977) identified three stages of metamorphism in the Hatrurim formation: (1) a high-temperature progressive metamorphism in which decarbonation and dehydration were the major chemical changes, (2) a retrograde metamorphism in the presence of a $\mathrm{CO}_{2}-\mathrm{H}_{2} \mathrm{O}$ fluid, leading to the development of zeolitebearing assemblages, and (3) chemically active weathering, with extensive hydration, recarbonation and, occasionally, sulfatization. The high-temperature origin of mineral assemblages has been confirmed in several studies. Bentor et al. (1972) heated nonmetamorphosed Ghareb and Taqiya sediments in air, obtaining characteristic Mottled Zone calc-silicates. Matthews and Nathan (1977), using the irreversible kinetics of carbonate-fluorapatite decarbonation as a geothermometer, showed that temperatures in excess of $300-400^{\circ} \mathrm{C}$ must have been generated in the event. Additional indications for a high-temperature origin of many assemblages come from the application of phase equilibrium studies to coexisting minerals: e.g., wollastonite + anorthite $\left(\mathrm{T}>520^{\circ} \mathrm{C}\right)\left(\right.$ Newton 1966); calcite + spurrite $\left(\mathrm{T}>520^{\circ} \mathrm{C}\right.$; data of Harker and Tuttle (1956) extrapolated in Matthews and Kolodny (1978); wollastonite +anorthite+gehlenite $\left(\mathrm{T}>800^{\circ} \mathrm{C}\right)$ (Newton 1966).

The mineral assemblages formed from the Ghareb and Taqiya formations during the progressive (heating) stages of metamorphism are typical of calcareous silica-deficient metasediments. Siliceous limestone compositions lead to the formation of spurrite and larnite and less commonly rankinite and wollastonite. The Hatrurim Formation is the type locality of the mineral Hatrurite $\left(\mathrm{Ca}_{3} \mathrm{SiO}_{5}\right)$, the equivalent of the cement phase $\mathrm{C}_{3} \mathrm{~S}$. Marly compositions result in the formation of melilite (mainly gehlenite), Ca garnets, diopside-hedenbergite and anorthite. In peraluminous silica-deficient compositions, assemblages 
containing brownmlllerite $\left(\mathrm{Ca}_{2}(\mathrm{Al}, \mathrm{Fe})_{2} \mathrm{O}_{5}\right)$ and mayenite $\left(\mathrm{Ca}_{12} \mathrm{~A}_{14} \mathrm{O}_{33}\right)$ develop. High-temperature minerals such as pseudowollastonite (high-temperature $\mathrm{CaSiO}_{3}$ ), and spinel are also found, though not commonly. Hazeva sediments are more siliceous and much less aluminous than Ghareb and Taqiya rocks and are mainly composed of metamorphosed conglomerates and quartzites in a calcite matrix. Monomineralic zones of $\mathrm{Ca}-\mathrm{Al}$ silicates are occasionally observed at calcium carbonate-silicate interfaces.

The metamorphism of the Eocene formations is less clear. Metamorphosed barite concretions are found in the upper parts of the complex (cf., Bentor and Vroman 1960), but these occur in "porous olive" (Gross 1977) and low-grade marble horizons in the Taqiya Formation rather than the Eocene. In some horizons at the top of the metamorphic sequence, larnite microcrystalline rocks (with minor gehlenite and bredigite) plus their retrograded equivalents (carbonates plus talc-silicate hydrates) may be representative of originally Eocene sediments. It is also possible that these formations were eroded away before metamorphism occurred, probably in the Late Miocene (Kolodny et al. 1971).

The prograde rocks are dominantly fine grained, typically exhibiting mosaic, granoblastic and poikiloblastic textures. Hornfels are common in gehlenite-anorthite-wollastonite-diopside-garnet rocks of the Taqiya Formation. Overprinting of the principal parageneses by rarer minerals and retrograde hydration and recarbonation products is ubiquitous. Very rarely coarse grained and occasionally pegmatitic high-grade assemblages occur, possibly due to recrystallization in the presence of a $\mathrm{H}_{2} \mathrm{O}$-rich fluid phase. Melting is rare in Mottled Zone rocks.

The zeolites can be grouped with grossular and diopside because of their general association with these minerals and with their low-temperature origin $\left(<250^{\circ} \mathrm{C}\right)$, but it is unclear at which stage of the metamorphism the zeolites formed. The zeolites are essentially silica undersaturated calc-zeolites, thompsonite, gismondite, phillipsite, chabazite, etc. Gross (1977) concluded they formed hydrothermally during retrograde metamorphism, but Matthews and Gross (1980) noted that, even though the zeolites frequently crystallize in veins or vugs, and the associated calcite often shows a retrograde symplectic texture, zeolite-bearing grossular-dopside rocks are quite common. Similarly, grossular, presumably formed during prograde heating, is sometimes surrounded by hydrogrossular rims (see Gross 1977, pp. $32-35$ and plate XIV), suggesting the reintroduction of $\mathrm{H}_{2} \mathrm{O}$ at low temperatures $\left(<200-300^{\circ} \mathrm{C}\right)$. Thermodynamic data argue against any simple calcite-zeolite association in retrograde conditions, since the presence of even a minute amount of $\mathrm{CO}_{2}$ in vapor phase (necessary for retrograde carbonate formation) would destabilize the calcite-zeolite assemblage in favor of aluminous clay $+\mathrm{CO}_{2}$ (Thompson 1971).

The third and final phase of metamorphic change is low-temperature hydration, recarbonation, and sulfatization. Texturally high-grade minerals such as spurrite, larnite, and brownmillerite are replaced by calcium carbonates and hydrated calc-silicates, tobermorites, apophyllite, portlandite, and when sulphur is mobilized, ettringite. Unstable carbonates, aragonite and vaterite form by recarbonation of $\mathrm{CaO}$. The carbonates are frequently symplectic, showing fibrous growth and spherulites and intergrowth of calcite with an isotropic silica-aluminous serpentine phase. In the presence of a $\mathrm{CO}_{2}-\mathrm{H}_{2} \mathrm{O}$ phase, this is probably the equilibrium equivalent of the zeolite-carbonate association. Phase equilibria amongst these hydrated minerals (Lea 1970) indicate a very low-temperature origin to many assemblages $\left(<50^{\circ} \mathrm{C}\right)$. In as much as the processes are continuing today, water of meteoric origin must be involved in hydration.

\section{ScaWt Hill, Larne, Co. Antrim, Northern IReland, UK}

Scawt Hill is the dominant feature on the skyline of the Antrim Coast Road near Ballygalley Head and Ballygalley. The summit of Scawt Hill (Grd Ref. D337090) rises some $30 \mathrm{~m}$ above the general level of the Antrim Plateau to a height of 378 m O.D. It may be seen along the East Antrim escarpment some 5 
km WNW of Ballygalley or $19 \mathrm{~km} \mathrm{NW}$ of Larne. The hill marks the outcrop of an olivine dolerite plug that intrudes the Cretaceous Ulster White Limestone and overlying Tertiary lavas of the Lower Basalt Formation. A high-temperature, low-pressure thermal metamorphism at the plug contacts produced unusual calc-silicate mineral assemblages in the limestone, and assimilation of the carbonate rock has produced a sequence of alkali basic igneous rocks just inside the old volcanic conduit.

C.E. Tilley, in a series of publications, notably those in the Mineralogical Magazine for 1929, 1931, and 1933, was the first to appreciate the nature and potential of the dolerite-limestone contacts. His writings inspired many other workers to find similar rock relationships worldwide; his interpretation of the associated alkali basic rocks also prompted a revision of the petrogenesis of similar rocks in many other countries.

The reaction had three main components: (1) the effect of heat on the limestone, (2) the penetration of high-temperature solutions from the melt into the limestone, and (3) assimilation of limestone into the margin of the magma. Investigations at Scawt Hill has yielded five new minerals (larnite, scawtite, rankinite, portlandite and hydrocalumite) and elucidated the relationships between a whole suite of rare minerals of similar chemistry. In all, 28 minerals are known from this site.

The dolerite plug has a roughly circular outcrop some $270 \mathrm{~m} \times 180 \mathrm{~m}$. Its steep cylindrical contact is defined by the east-facing precipitous cliff (30-60 m high) where curving joints parallel the outer contact, and it is well exposed in two steep gullies at the SE and NE corner of the hill. Metamorphic and metasomatic effects in this area have been separated into two zones. The exogenous zone, the region outside of the initial contact, and the endogenous zone, the area inside the contact affected by assimilation of limestone into the magma. It is the rocks of the exogenous zone that are of most interest as analogs for the long-term behavior of high-silica cements.

The Cretaceous Ulster White Limestone (exogenous zone) forms conspicuous crags south of the plug and extends as a thin veneer on the steep slope of the hill. The pure carbonate rock, free from detrital materials and containing only flint nodules, passes into a coarse marble towards the dolerite contact and within $\sim 60-120 \mathrm{~cm}$ of the contact changes to a silicate assemblage. It is this silicate assemblage that is the analog material of interest. This assemblage is best developed at the foot of the SE gully.

The silicate zone may reach a thickness of $60 \mathrm{~cm}$ and is variable in its mineral assemblage; the principal rock types are spurrite-rock (with or without calcite), larnite-rock (with or without spurrite), spurritelarnite-gehlenite-rock, and spurrite-gehlenite-merwinite-spinel-rock (with or without larnite).

Larnite, named after the township of Larne, was the first recorded natural occurrence of calcium orthosilicate. It is never found in direct contact with calcite-spurrite always intervenes. Magnetite, perovskite, wollastonite, xonotolite, gyrolite, afwillite, okenite, pectolite, cebollite, bredigite, plombierite, rankinite, hydrocalumite, portlandite, and ettringite also occur in these assemblages. These formed when solutions from the dolerite magma enriched the contact zone in silica, magnesia, iron oxides, and alumina.

The flint nodules also show progressive metamorphic and metasomatic changes towards the dolerite contact. At first the flint (chalcedony) recrystallizes to granular quartz, and a reaction rim of wollastonite develops between the nodule and the enclosing limestone. Some lime migrates and forms stringers of wollastonite within the nodule. Nearer the contact sheaves of greenish xonotolite crystals with associated wollastonite prisms rim the nodule and may completely replace the chalcedony. Green pyroxene, hedenbergitic diopside, aegerine and okenite have been identified. Close to the igneous contact, the nodules are replaced by dark green augite-aegerine and wollastonite, the latter sheathed with pectolite; melilite altered to magnetite and cebollite also occur. 
At the NE gully the metamorphic and metasomatic changes are more restricted, but several centimetres of larnite rock develop. The flint nodules encased and veined by this calc-silicate material show extensive hydration to mineral gels such as plombierite. The north contact of the plug can be traced above this NE gully, and small exposures contain metamorphosed basalts. In the endogenous zone the marginal dolerite was extensively modified by assimilation of the carbonate country rock, forming pyroxenites of progressively more alkaline compositions. Again, the best occurrence is in the SE gully, where veins of pyroxenite penetrate the exogenous zone. In this zone the normal olivine dolerite merges within a meter of the contact into pyroxene-rich dolerite that contains vesicles lined with thomsonite associated with analcime, stilbite, natrolite, scawtite, and calcite. Zeolite minerals, along with hydronephelite, may replace the plagioclase. The pyroxene is enriched in diopside as a result of lime assimilation. 



\section{APPENDIX C: ANNOTATED BIBLIOGRAPHY}



Applicable sections of works cited in this document are given in this Appendix. The annotated references are not inclusive, but are intended to give insight into the background research that supports this document.

\section{ACI 221R-96. 2001. "Guide for Use of Normal Weight and Heavyweight Aggregates in Concrete."}

This guide presents information on selection and use of normal weight and heavyweight aggregates in concrete. The selection and use of aggregates in concrete should be based on technical criteria as well as economic considerations and knowledge of types of aggregates generally available in the area of construction. The properties of aggregates and their processing and handling influence the properties of both plastic and hardened concrete.

For high-strength concrete, crushed cubical coarse aggregate generally produces higher compressive strength than rounded gravel of comparable grading and quality.

For example, an excess of aggregate in any one size may cause harshness in the mixture. In some instances, gap gradings with reduced amounts of aggregate in the coarse fine aggregate sizes and small coarse aggregate sizes (particularly if angular particles are present in these sizes) have been found to be very workable where consolidation is by vibration even though slump is not high (Ehrenburg 1980, Li and Ramakrishnan 1974, and Li, et al. 1969).

In lean (low cement factor) concrete, workability may be improved and cohesion increased with the presence of higher amounts of silt- and clay-size fines in the aggregate.

Concrete made with more angular or poorly graded aggregates is expected to be more difficult to pump because of its higher internal friction. The particle shape of coarse aggregate will have a modest effect on pumpability and line pressure. The properties of fine aggregate play an important part in proportioning pumpable mixtures.

\section{ACI 233R-03. 2004. "Slag Cement in Concrete and Mortar."}

The use of ground granulated iron blast-furnace slag cement (slag cement) as a cementitious material dates back to 1774 when Loriot made a mortar using slag cement in combination with slaked lime (Mather 1957).

A discussion of the basic principles of slag cement hydration makes it possible to identify the primary factors that, in practice, will influence the effectiveness of the uses of slag cement in concrete and mortar. These factors are

a. Chemical composition of the slag cement and Portland cement;

b. Alkali-ion concentration in the reacting system;

c. Glass content of the slag cement;

d. Fineness of the slag cement and the Portland cement; and

e. Temperature during the early phases of the hydration process.

\section{ACI 211.1-97. 1997. "Standard Practice for Selecting Proportions for Normal, Heavyweight, and Mass Concrete, American Concrete Institute."}

This Standard Practice describes methods for selecting proportions for hydraulic cement concrete made with and without other cementitious materials and chemical admixtures. This concrete 
consists of normal and/or high-density aggregates (as distinguished from lightweight aggregates) with workability suitable for usual cast-in-place construction (as distinguished from special mixtures for concrete products manufacture). Also included is a description of methods used for selecting proportions for mass concrete. Hydraulic cements referred to in this Standard Practice are Portland cement (ASTM C 150) and blended cement (ASTM C 595). The Standard does not include proportioning with condensed silica fume. The methods provide a first approximation of proportions intended to be checked by trial batches in the laboratory or field and adjusted, as necessary, to produce the desired characteristics of the concrete.

U.S. customary units are used in the main body of the text. Test methods mentioned in the text are listed in Appendix 3 of the Standard.

Keywords: absorption, admixtures, aggregates, blast-furnace slag, cementitious materials, concrete durability, concretes, consistency, durability, exposure, fine aggregates, fly ash, heavyweight aggregates, heavy-weight concrete, mass concrete, mix proportioning, pozzolans, quality control, radiation shielding, silica fume, slump tests, volume, water-cement ratio, watercementitious ratio, workability.

ACI Standards 211.1 and 304R provide that, for concrete that is to be pumped, the amount of coarse aggregate may be decreased by up to $10 \%$. This means that the mortar-coarse aggregate ratio may be increased if necessary to provide for more workable concrete.

\section{Anderson, G. M. 1996. Thermodynamics of Natural Systems, "Chapter 9: Redox Reactions." University of Toronto, John Wiley \& Sons, Inc., Toronto.}

This is a monograph on natural water systems and their thermodynamic properties. Describes the Eh and $\mathrm{pH}$ interrelationships as well as the $\mathrm{EH}$ vs. $\mathrm{pH}$ plots for some uranium species. The relationship of Eh to dissolved $\mathrm{O}_{2}$ (a) and $\mathrm{pH}$ can be reduced to

$$
\mathrm{Eh}=1.23+0.0148 \log f_{\mathrm{o}_{2}}-0.0592 \mathrm{pH}
$$

where $f_{\mathrm{O}_{2}}$ is the dissolved oxygen fugacity.

\section{Archibald, James F., Charles W. Pelley, Samantha J. Espley, and David O. DeGagné, 2004. "Economic and Productivity Comparison of Bolt and Screen, Shotcrete and Polymer Rock Support Methods," http://mine.queensu.ca/people/faculty/Archibald/SupportCostsPaper.pdf .}

Underground mining rock support for ground control, while necessary for safe and effective modern mining, is time consuming and expensive. The most common types of rock support in use today are the combination of rock bolts and mesh screens and various forms of shotcrete (Archibald et al. 2004). More recently, innovative spray-on polymer linings have been developed for use as an alternative type of rock support. Initial research indicates that bolt and screen support is relatively inexpensive but is not as productive as either shotcrete or polymer linings and is not readily automated. Shotcrete is significantly more productive than using screen and bolts, but is considerably more expensive and requires substantially more material handling. Spray-on liners tend to have high material costs associated with them, but they result in significantly increased productivity and reduced material handling efforts compared to the other support systems. 
ASTM C 136-01. 2001. "Standard Test Method for Sieve Analysis of Fine and Coarse Aggregates."

This test method covers the determination of the particle size distribution of fine and coarse aggregates by sieving.

\section{ASTM C 150 - 02a. "Standard Specification for Portland Cement."}

This specification covers eight types of Portland cement, as follows:

Type I-For use when the special properties specified for any other type is not required.

Type IA-Air-entraining cement for the same uses as Type I, where air-entrainment is desired.

Type II-For general use, when moderate sulfate resistance or moderate heat of hydration is desired.

Type IIA-Air-entraining cement for the same uses as Type II, where air-entrainment is desired.

Type III-For use when high early strength is desired.

Type IIIA-Air-entraining cement for the same use as Type III, where air-entrainment is desired.

Type $I V$ - For use when a low heat of hydration is desired.

Type $V$-For use when high sulfate resistance is desired.

\section{ASTM C 595 - 03. "Standard Specification for Blended Hydraulic Cements."}

This specification pertains to five classes of blended hydraulic cements for both general and special applications, using slag or pozzolan, or both, with Portland cement or Portland cement clinker or slag with lime.

\section{ASTM C 618-99. "Standard Specification for Coal fly Ash and Raw or Calcined Natural Pozzolan for Use as Admixtures in Concrete."}

This specification covers coal fly ash and raw or calcined natural pozzolan for use as a mineral admixture in concrete where cementitious or pozzolanic action, or both, is desired.

\section{Classification:}

Class $\mathrm{N}$-Raw or calcined natural pozzolans that comply with the applicable requirements for the class as given herein, such as some diatomaceous earths; opaline cherts, and shales, tuffs and volcanic ashes or pumicites, calcined or uncalcined; and various materials requiring calcination to induce satisfactory properties, such as some clays and shales.

Class $\boldsymbol{F}$-Fly ash normally produced from burning anthracite or bituminous coal that meets the applicable requirements for this class as given herein. This class fly ash has pozzolanic properties. Class $\boldsymbol{C}$-Fly ash normally produced from lignite or sub-bituminous coal that meets the applicable requirements for this class as given herein. This class of fly ash, in addition to having pozzolanic properties, also has some cementitious properties.

\section{ASTM C 989 - 04. "Standard Specification for Ground Granulated Blast-Furnace Slag for Use in Concrete and Mortars."}

This specification covers three strength grades of finely ground granulated blast-furnace slag for use as a cementitious material in concrete and mortar. Slag is classified by performance in the slag activity test in three grades: Grade 80, Grade 100, and Grade 120 .

Sulfur in granulated blast-furnace slag is present predominantly as sulfide sulfur. In most cases, instrumental analyses, such as X-ray fluorescence, cannot differentiate sulfide sulfur from sulfate. 
Determine and report the sulfide sulfur content separately, and do not include it in the $\mathrm{SO}_{3}$ calculations.

Brookins, D. G. 1976. Shale as a Repository for Radioactive Waste: The Evidence from Oklo, Environ. Geol. 1, pp. 225-269.

Natural analogs are the only means by which very slow mechanisms can be identified and by which the pertinence (if not validation) of long-term models' predictions can be tested.

Chapman, N. A.; McKinley, I. G.; and Smellie, J. 1984. The Potential of Natural Analogs in Assessing Systems for Deep Disposal of High-Level Radioactive Waste. NAGRA Tech. Rept. NTB 84-41.

Chapman et al. were looking for the best criteria to identify analogs among natural objects. Their criteria for good similarity with a disposal system for part of it (e.g., nature of materials, geological or geochemical situation) define an analog.

Chen, F.; R. C., Ewing; and S. B., Clark. 1999. "The Gibbs Free Energies and Enthalpies of $\mathbf{U}^{6+}$ Phases: An Empirical Method of Prediction.” American Mineralogist Vol. 84, pp. 650-664.

Chen et al. determined values and the average residuals associated with the predicted $\Delta G^{0}$ and $\Delta H^{0}{ }_{\text {f }}$ for the uranyl phases used in the model are 0.08 and $0.10 \%$, respectively, well below the limits of uncertainty for the experimentally determined values. To analyze the reliability of the predicted $\Delta G^{0}$ values, activity-activity diagrams in $\mathrm{SiO}_{2}-\mathrm{CaO}-\mathrm{UO}_{3}-\mathrm{H}_{2} \mathrm{O}$ and $\mathrm{CO}_{2}-\mathrm{CaO}-\mathrm{UO}_{3}-\mathrm{H}_{2} \mathrm{O}$ systems at $298.15 \mathrm{~K}$ and 1 bar were constructed using the predicted $\Delta G_{\mathrm{f}, 298.15}^{0}$ values for the relevant $\mathrm{U}^{6+}$ phases. There is good agreement between the predicted mineral stability relations and field occurrences, thus providing confidence in this method for the estimation of $\Delta G^{0}$ and $\Delta H^{0}$ of the $\mathrm{U}^{6+}$ phases.

Daube, J. and R. Bakker.1986. Portland Blast-Furnace Slag Cement: A Review. ASTM-STP 897, G. Frohnsdorff, Ed., American Society for the Testing and Materials, Philadelphia, pp. 5-14.

This document reviews characterizations of blast-furnace slags' compositions and reactivity indexes, as well as strength development and volume stabilities. The two main characteristics that determine the quality of blast-furnace slags are (1) the composition and (2) the vitreous state. There is an empirical formula that characterizes the cementitious quality of slags. Normal range for $I_{h}$ is from 1.65 to 1.85 and the vitreous fraction of the slag should range between 60 to $80 \%$ by weight.

De Belie, N.; Hans Jurgen Verselder; Benny De Blaere; Dirk Van Nieuwenburg; and Reinhart Verschoore. 1996. Influence of the Cement Type on the Resistance Concrete to Feed Acids, Cement and Concrete Research, Vol. 26, No. 11, pp. 1717-1725.

Chemical attack by the most important feed acids, lactic and acetic acid (De Belie et al. 1996). Lactic and acetic acid are very aggressive because their reaction with free lime $\left(\mathrm{Ca}(\mathrm{OH})_{2}\right)$ of the concrete produces very soluble calcium salts (Kleinlogel 1960). When those salts are leached, the concrete porosity will increase and the $\mathrm{pH}$ in the pores will decrease. Furthermore calcium lactate crystals may cause an internal stress in the concrete, resulting in cracks. The hydrates of the hardened cement paste will start decomposing and the concrete disintegrates. 
The resistance of concrete to chemical attack is mainly determined by its permeability, its alkalinity and the chemical composition of the cement paste. The permeability mainly depends on the geometry of the pores and their distribution. The lower $\mathrm{Ca}(\mathrm{OH})_{2}$ content and the finer pore structure of blast furnace slag concrete and fly ash concrete could therefore contribute to a larger resistance.

Dodge, C. J.; A. J. Francis; J. B. Gillow; G. P. Halada; C. Eng; and C. R. Calton. 2002. "Association of Uranium with Iron Oxides Typically Formed on Corroding Steel Surfaces." Environ. Sci. Techno. 36, pp. 3504-351.

The iron oxide coating formed on steel surfaces is influenced by the type of steel as well as by environmental factors, including oxygen, moisture, the presence of other ions, and the $E \mathrm{~h}$ and $\mathrm{pH}$ of the local environment. Radionuclides incorporated into the iron oxides formed on corroding steel surfaces. The iron oxide coating formed on steel surfaces is influenced by the type of steel as well as by environmental factors, including oxygen, moisture, the presence of other ions, and the $E \mathrm{~h}$ and $\mathrm{pH}$ of the local environment. The oxides found on corroding steel surfaces include ferrihydrite, goethtite, green rusts (GRs), hematite, lepidocrocite, maghemite, and magnetite. Wolski identified the presence of an ordered maghemite on iron couplers buried in the soil for extended periods. McGill et al. concluded that a stable green rust formed on cast-iron pipes was structurally different from that of green rust II (GR II).

The oxides commonly associated with corroded steel surfaces include ferrihydrite, goethtite, GR II, lepidocrocite, maghemite, and magnetite. The association of uranium with the oxide is dependent on the nature of the oxide. Addition of the uranyl ion to iron oxides resulted in its attachment to surface sites as an inner-sphere bidentate complex. The addition of uranium during coprecipitation with iron may result in bi- and tri-dentate bonding with iron, formation of di- and tri-nuclear Fe-U complexes, and polymeric forms of uranium oxyhydroxide. During the crystallization process, the uranium may also become encapsulated into the oxide as a microcrystalline phase.

Dole, L. R. 1991. “Fixation of Pumping Station Contaminated Soils.” Proceedings of the HMCRINortheast '91 Conference, Hazardous Materials Control Research Institute, Boston, Massachusetts, pp. 292-293, July 10-12.

This study reports the in situ solidification of petroleum hydrocarbons and PCBs in a gas pipeline pumping station blow out pit in the Floridian panhandle.

Dole, L. R.; M. W. Grutzeck; and P. H. Licastro. 1993, “Final Report: Performance Verification Study on the Solidification/Stabilization Waste Form for PCB-Contaminated Soils at the Rail Yard in Paoli, Pennsylvania.” Ogden Environmental and Energy Services, 1009 Commerce Park Drive, Oak Ridge, Tennessee 37830, January 28.

This study measures diffusion-controlled PCB leachability from solidified, oily rail yard soils.

Eng, C. W.; G. P. Halada; A. J. Francis; C. J. Dodge; and J. B. Gillow. 2003. “Uranium Association with Corroding Carbon Steel Surfaces.” Surf. Interface Anal. 35, pp. 525-535.

In general, heavily corroded areas physically shield the uranium species, which tended to associate spatially with hydroxyl groups and lepidocrocite. Lightly corroded areas contained uranium species with stronger axial U-O bonding. Infrared spectroscopy, Rutherford backscattering spectroscopy, and energy-dispersive spectroscopy mapping analysis revealed that 
the uranium species are well distributed within the upper micron of the thick corrosion layer and associated more with areas of high hydroxide content.

Coupons that were heavily corroded prior to exposure retained more uranium species than cleaned steel coupons that only possess a thin native oxide layer. Coupons that were heavily corroded have a rough and spalling surface, which promotes more uranium-corrosion product interactions due to the greater surface area of the corrosion product layer.

\section{Ewing, R. C. 1979. “Natural Glasses: Analogs for Radioactive Waste Forms.” Mater. Res. Soc.} Symp. Proc. 1, 57-68.

In a parody of the famous sentence of the renowned eighteenth century geologist, Hutton, who founded the geological method ("the present is the key to the past"), R. C. Ewing says that the past is also the key to the future, meaning that our ability to predict the likely evolution of a repository must be evaluated against our capability of thoroughly explaining past geological events (defined as the process of post-diction, as opposed to prediction, in reference to the work of Simpson on historical sciences). He finally argues that such reasoning does not "demonstrate that our understanding is correct, but it does add to the demonstration of the general applicability and acceptability of the approach."

\section{Faucon, P.; F. Adenot; J. F. Jacquinot; J. C. Petit; R. Cabrillac; and M. Jorda, M. 1998. "Long- Term Behavior of Cement Pastes used for Nuclear Wastes Disposal: Review of Pysico- Chemical Mechanisms of Water Degradation." Cement and Concrete Reseach Vol. 28(6), pp. 847-857.}

A review of physical-chemical processes of degradation of (ordinary Portland cement) waste forms in water, the effects and their time scales. When silica rises in the adjacent solution, an aluminosilicate film greatly reduces the dissolution rate, higher $\operatorname{Si}(\mathrm{OH}) 2(-2 \mathrm{a})$ concentrations in the interstitial solution stabilizes the protective layer.

\section{Finch, R. J. 1997. "Thermodynamic Stabilities of U(VI) Minerals: Estimated and Observed Relationships, Scientific Basis for Nuclear Waste Management XX," Materials Research Society Proceedings, W.J. Gray and I.R. Triay , Eds., 465, pp. 1185-1192.}

Because the uranyl oxide hydrates, $\mathrm{U}(\mathrm{OH})_{\mathrm{x}}$ are the first corrosion products to form on uraninite, their paragenesis provides insight as to the reaction path for uraninite corrosion.

The precipitation of uranyl silicates directly from solution requires large over saturations, and this favors the early formation of $\mathrm{U}(\mathrm{OH})_{\mathrm{x}}$, such as schoepite, which can apparently form from solutions with significant silica concentrations. Small inclusions (unidentified) of uranyl silicates occur within schoepite grains, suggesting that silica was present in the ground water, but that nucleation and growth proceed more rapidly for schoepite than for the uranyl silicates.

The uranophane group $(\mathrm{U}: \mathrm{Si}=1: 1)$ is the most abundant of the uranyl silicates both in number of phases (nine) and in abundance. Uranophane $(\mathrm{Ca})$ and sklodowskite $(\mathrm{Mg})$ are the most common. The 1:3 silicates (the "haiweeite group") are only known from Si-rich environment such as tuffaceous rocks, where weeksite is common. Uranosilite is indicative of still higher Si activities, but this phase has been reported from only one locality - Menzenschwand, Germany (Walenta 1968). Lepersonite and soddyite are indicative of more U-rich solutions, and both occur in close proximity to corroded uraninite. There is virtually no data on important U-Si complexes. 
Langmuir (1978) notes only $\mathrm{O}_{2} \mathrm{SiO}(\mathrm{OH})(+3 \mathrm{a})$ in dilute solutions, where it may predominate in a narrow range of $\mathrm{pH}$ near six.

\section{Flint, L. E. 1998. Characterization of Hydrogeologic Units Using Matrix Properties, Yucca Mountain, Nevada, Water-Resources Investigations Report 97-4243. US Geological Survey, Denver, CO, 64 pp.}

The Topopah Spring welded unit (Montazer and Wilson 1984) consists of a very thin upper vitrophyre; a thick central zone consisting of several densely welded, devitrified ash-flow sheets; and a thin lower vitrophyre. The unit contains several lithophysal cavity zones of varying thickness, and the rocks are intensely fractured. This unit is the thickest and most extensive of the Paintbrush Group and contains the central and lower densely welded and devitrified zones being considered for the potential repository. The vitric, densely welded (Tptrvl) subzone, which contains the vitrophyre, is typically less than $0.5 \mathrm{~m}$ thick, but varies from 0 to $2 \mathrm{~m}$ thick across Yucca Mountain (D.C. Buesch and R.W. Spengler, U.S. Geological Survey, written communication 1996). The Tptrvl typically has porosity less than $5 \%$. It has highly contrasting properties to the rocks overlying it. The underlying dense subzone of the crystal-rich nonlithophysal zone (Tptrn3) also has very low porosity (less than $9 \%$ ) and can be combined with the Tptrvl as the hydrogeologic unit $\boldsymbol{T C}$. Tptrn3 is typically thicker to the north and very thin in the southern parts of the study area. Most of the crystallized, moderately to densely welded Topopah Spring Tuff is divided into five hydrogeologic units that closely correspond to lithostratigraphic units. The vapor-phase corroded and crystaltransition subzones of the crystalrich nonlithophysal zone (Tptrn2) have porosity similar to the underlying lithophysal zone, but moisture-retention characteristics differ.Therefore, Tptm 2 is represented by $\boldsymbol{T} \boldsymbol{R}$ and has greater than $9 \%$ porosity. The lithophysal (Tptrl, Tptpul, and Tptpll) and nonlithophysal (Tptprnn, Tptpln) zones differ in porosity with the lithophysal zones being approximately $14 \%$ porosity and the nonlithophysal zones approximately $11 \%$.

They differ particularly in moisture-retention characteristics; therefore, each zone is represented by individual hydrogeologic units: TUL, the upper lithophysal zone; TMN, the middle nonlithophysal zone; TLL, the lower lithophysal zone; and TM2 and TM1, comprising the lower nonlithophysal zone. The lower nonlithophysal zone of the Topopah Spring Tuff transitions into lower porosity (approximately $9 \%$ ) and locally vitric rocks at the base that have different moisture- retention characteristics due to a downward increase in the amount of smectite (Bish and Chipera 1989) and is, therefore, divided into two hydrogeologic. units. Vitric rocks at the base of the Topopah Spring Tuff are highly contrasting in porosity with rocks above and below them. The very low-porosity densely welded subzone (Tptpv3), which contains the vitrophyre, is a discrete hydrogeologic unit, PV3. The moderately welded subzone (Tptpv2) is PV2. The nonwelded base of the Topopah Spring Tuff, Tptpvl, is similar in properties to the underlying bedded tuff, Tpbtl, and they are combined in hydrogeologic unit BTI.

\section{Fulton, F. S. 1974. The Properties of Portland Cement Containing Milled Granulated Blast-Furnace Slag. Monograph, Portland Cement Institute, Johannesburg, pp. 4-46.}

Fulton investigated workability in great detail and suggested that a cementitious matrix containing slag cements exhibited greater workability due to the increased paste content and increased cohesiveness of the paste. Wood (1981) reported that the workability and placeability of concrete containing slag cement was improved when compared with concrete containing no slag cement. He further stated that this result was due to the surface characteristics of the slag cement, which created smooth slip planes in the paste. He also theorized that, due to the smooth, dense surfaces of the slag cement particles, the slag cement absorbed little if any water during 
initial mixing, unlike Portland cement. Wu, Roy (1982) found that pastes containing slag cements exhibited different rheological properties compared with pastes of Portland cements alone. Their results indicate a better particle dispersion and higher fluidity of the pastes and mortars, both with and without water-reducing admixtures. Concrete containing slag cement is consolidated under mechanical vibration more easily than concrete that does not contain slag cement.

Gaal, G. C. M.; A Van Beck; J.D. Baker; and J. C. Walraven. 2003. "Coefficient of Diffusion Derived from Structure Exposed to Chloride More than 60 Years Old." Proceedings of the 2nd International Workshop on Life Predication and Aging of Management of Concrete Structures, Paris, France. May 5-6, PRO 29, RILEM Bagneux, France, pp. 21-29.

In a Study of Dutch bridge columns exposed to concentrated de-icing chloride solutions for up to 62 years, cements with low blast furnace slag substitutions at only 30 to $50 \%$ by weight showed chloride-ion $\left(\mathrm{Cl}^{-}\right)$diffusion coefficients of less than $<1 \times 10^{-9} \mathrm{~cm}^{2} / \mathrm{s}$. These are considered less durable than modern blast furnace cements at substitution levels or $70 \%$ by weight.

Giordana S.; I. Mabille; and C. Fiaud. 2003. "Inhibiting Effect of Silicates on Corrosion of Low Silicon Alloyed Steels in Neutral Non-Oxidizing Conditions at $90^{\circ}$ C." Corrosion Engineering, Science and Technology 38 (no. 4), pp. 291-297(7), December 1. Marine Engineering Organization, UK, Corrosion inhibitors used in Jacket Water System, http://www.marineengineering.org.uk/motjktwtr/motcorinhibMain.htm, 2004.

Unalloyed and low-alloyed steels undergo predictable uniform corrosion and are potential candidates for high-level nuclear waste disposal containers. In this study, low-alloyed silicon steel $\left(<5 \mathrm{wt} \% \mathrm{Si}\right.$ ) has been tested in a silicate containing corrosive solution at $90^{\circ} \mathrm{C}$ in order to establish whether the addition of silicon to iron would improve the resistance of the surface film to corrosion in an argillaceous (i.e., clayey) soil. Electrochemical tests were conducted for shortterm immersion of the steel coupons and showed that the addition of silicate to the corrosive solution decreased the corrosion rate, whereas the addition of silicon to the steel increased the critical passivation current peak. The inhibiting effect of sodium silicate was significantly increased after some hours of immersion, and the Si alloyed steel was more easily protected than the carbon steel.

Glasser F. P. 1993. Chemistry of Cement-Solidified Waste Forms, in Chemistry and Microstructure of Solidified Waste Forms. Edited by R. D. Spence, Oak Ridge National Laboratory, Lewis Publishers.

Glasser indicates that in the case of uranium doped cements, the solubility in the short term is caused mainly by $\mathrm{pH}$ conditioned precipitation of hydrous oxides but, in the long term the hydrated compounds that uranium form with calcium and silicon are lowering the solubility by orders of magnitude. Uranium is in the $\mathrm{U}^{+6}$ phase in the cement matrix.

Glasser, F. P., S. Diamond; and D. M. Roy. 1986. "Hydration Reactions in Cement Pastes Incorporating Fly Ash and Other Pozzolanic Materials." Proceedings of the Materials Research Society Vol. 85, Microstructural Development During Hydration of Cement, L.J. Struble and P.W. Brown, Eds., December 2-4, Boston, Massachusetts, Materials Research Society, Pittsburgh, Pennsylvania, pp. 167-186.

Higher silica content of blended cements pastes develop finer pore structures and have enhanced chemical resistance. 
Glasser, F.P. and S.-Y. Hong. 2003. "Thermal Treatment of C-S-H Gel at $1 \mathrm{Bar} \mathrm{H}_{2} \mathrm{O}$ pressure up to $200^{\circ}$ C," Cement and Concrete Research, 33, 271-279.

Gels with high Si/Ca ratios partially crystallized at $85^{\circ} \mathrm{C}$. At $130^{\circ} \mathrm{C}$ in steam, crystalline products included 11 and $14 \mathrm{~A}^{\circ}$ tobermorite, xonotlite, afwillite, portlandite and another incompletely characterized phase. At $200^{\circ} \mathrm{C}$, the gels retained much water but remained amorphous to X-ray powder diffraction (XRD). However, electron microscopy, coupled with diffraction and analysis, disclosed that the "amorphous" product obtained at $85-200^{\circ} \mathrm{C}$ had undergone crystallization with domains typically $10-1000 \mathrm{~nm}$.

Silica is usually added in reactive form, e.g., as quartz flour, fly ash, etc., to lower the bulk $\mathrm{Ca} / \mathrm{Si}$ ratio to $0.8-1.5$. This leads to development of phases such as tobermorite, xonotlite and possibly afwillite, which enable better strength retention and reduced solubility in an aqueous phase, relative to either OPC or $\mathrm{Ca}(\mathrm{OH}) 2$ or mixtures H.F.W. Taylor (1990).

Comparing treatments at 130 and $200^{\circ} \mathrm{C}$, and restricting comparison to largely non-crystalline reparations, the content of water is reduced by high temperature treatment (Glasser and Hong 2003). Very little of the remaining water in $200^{\circ} \mathrm{C}$ product can be removed upon subsequent drying at $<105^{\circ} \mathrm{C}$. The amount of water retained to higher temperature, $>105^{\circ} \mathrm{C}$, is therefore substantial and is in theory sufficient to form all but the more highly hydrated crystalline phases of the $\mathrm{CaO}-\mathrm{SiO} 2-\mathrm{H} 2 \mathrm{O}$ system.

\section{Gowripalan, N., P. Salonga, and C. Dolden.1997. "Residual Strength of High-Performance Concrete Subjected to High Temperatures,' in proceedings of ACI International Conference on High-Performance Concrete, Malaysia, ACI SP-172-10, pp. 171-191.}

This paper presents results of NIST experimental program on the effects of elevated temperature exposure on the mechanical properties and potential for explosive spalling of high strength concrete (HSC). Mechanical properties of HSC were measured by heating $100 \times 200 \mathrm{~mm}$ cylinders at $5^{\circ} \mathrm{C} / \mathrm{min}$ to temperatures of up to $600^{\circ} \mathrm{C}$, and heat-induced pore pressure buildup was measured by heating $100 \times 200 \times 200 \mathrm{~mm}$ blocks to the same temperature level at the same heating rate. The results of NIST mechanical property measurement are compared with results obtained in other studies as well as with existing code provisions to evaluate their applicability to HSC. The paper also presents results of measurement that indicate the efficacy of polypropylene fibers for mitigation of explosive spalling.

\section{Harris, A. W.; M. C. Manning; W. M. Tearle; and C. J. Tweed. 2002. "Testing of Models of the Dissolution of Cements-Leaching of Synthetic CSH Gels," Cement and Concrete Research 32, pp. 731-746.}

The exhaustive leaching of a range of synthetic calcium silicate hydrate (CSH) gels in dematerialized water has been studied. This has tested the applicability of experimental data and models based on the static dissolution of synthetic CSH gels in pure water (dissolution of a set of $\mathrm{CSH}$ gels with a range of compositions, each at effectively constant composition) to the description of the slow leaching of cementitious materials by flowing waters. This provides additional confidence in the modeling of the long-term evolution of conditions in a repository backfilled with cementitious materials and thereby helps underpin the assessment of the performance of such a repository. The results demonstrate that the initial stages of the dissolution of a range of CSH gels in dematerialized water are apparently incongruent, followed by an approach to congruent behavior. This behavior is broadly similar to that predicted from the static 
dissolution of $\mathrm{CSH}$ gels. The congruently dissolving composition is found at a $\mathrm{Ca} / \mathrm{Si}$ ratio of approximately 0.8 to 0.9 . This is comparable to the ratio of about 0.8 suggested by static dissolution. However, sequential leaching of CSH gels apparently results in a lower solubility for the congruently dissolving composition than is predicted from static dissolution. The experimental results are compared with data obtained from static dissolution measurements for synthetic CSH gels and with the predictions of a computer model based on the Berner model of cement dissolution (Berner 1988). The need to revise the model of dissolution to take account of the behavior of CSH gels during sequential leaching is examined.

Although CSH gels are believed to be metastable with respect to crystalline CSH minerals such as tobermorite and afwillite, they are known to persist for extremely long times under geological conditions (McConnell 1955, Milodowski et al. 1989). Consequently, predictions of the evolution of the equilibrium chemistry in a repository have concentrated on defining the contribution from the dissolution of CSH gels (Atkinson 1985, Atkinson et al. 1987, Harris 1998, Glasser et al. 1985, and Neall 1996).

Berner suggests that the static dissolution data indicate that the congruently dissolving composition lies at a $\mathrm{Ca} / \mathrm{Si}$ ratio of approximately 0.8 (Berner 1988). Atkinson et al. (1989) similarly suggest a value of $0.8-0.9$. The congruently dissolving composition from static leaching is apparently comparable with that of the crystalline $\mathrm{CSH}$ mineral tobermorite, typically assumed to be $\mathrm{C}_{5} \mathrm{~S}_{6} \mathrm{H}_{5-9}$ (Berner 1992, Taylor 1990, Atkinson and Hearne 1989). The results from CSH gel these previous leaching may be interpreted as being consistent with these assertions.

However, some authors have proposed compositions closer to a $\mathrm{Ca} / \mathrm{Si}$ ratio of unity, commonly as the basis for modeling. For example, Berner adopted a composition of $\mathrm{CaH}_{2} \mathrm{SiO}_{4}(\mathrm{CSH})$ as the notional end member for the description of the portlandite-CSH gel system as a solid solution (Berner 1992, Harris et al. 1997). Kersten has suggested a similar composition, $\mathrm{CaH}_{4} \mathrm{SiO}_{5}$ (Kersten 1996). It may be observed that the congruently dissolving composition indicated by the $\mathrm{CSH}$ gel leaching results is not entirely consistent with these end member compositions.

Results from more recent leaching tests demonstrate that the initial stages of the dissolution of a range of CSH gels into dematerialized water are not incongruent, and are then followed by an approach to congruent behavior (Harris et al. 2002). This sequential leaching of CSH gels apparently results in a lower solubility for the congruently dissolving composition than is predicted from static dissolution. Therefore, the Berner model of cement dissolution (Berner 1988) needs to be revised to take account of the behavior of CSH gels during sequential leaching.

Herrera, L. K.; C. E. Arroyave; and H. A. Videla. 2003. PRO 34, "The Use of Methods for Material Characterization, Surface Analysis Techniques and Atmospheric Aggressiveness in the Study of the Biodegradation of Two Sites of Cultural Heritage in the City of Medellin, Columbia.” Proceedings of the International RILEM Conference on Microbial Impact on Building Materials, September 8-9, 2003. Lisbon, Portugal. M.R. Silva, Ed., RILEM Publications, S.A.R.L., Bagneux, France, pp. 13-23.

This is a study of colonies of biological fauna on building in Medellin, Columbia, in which analysis techniques and methods are developed.

Hooton, D. R.1986. Permeability and Pore Structure of Cement Pastes Containing Fly Ash, Slag, and Silica Fume, Blended Cements. ASTM-STP 897. G. Frohnsdorff, Ed., American Society for the Testing and Materials, Philadelphia, pp. 128-143. 
This is a study of blast furnace slag's influence on reducing the porosity and permeability of as cement paste.

Hoyle, S. Q.1988. Cesium and Strontium Partitioning During Hydration of Calcium Aluminosilicates. Ph.D. thesis, The Pennsylvania State University, University Park.

This is the Penn State University Ph.D. thesis that reports the composition of $\mathrm{CaO}-\mathrm{SiO}_{2}-\mathrm{Al} 2 \mathrm{O} 3$ positional relationships that prevent Portlandite formation.

IAEA. 1989. Natural Analogs in Performance Assessment of the Disposal of Long-Lived Radioactive Waste. Technical Report series No. 304.

Panel of international experts review, discuss and acknowledge the use of natural analogs in performance assessment from both a qualitative and quantitative point of view. They describe three areas:

Development of conceptual models: In the case of waste-forms, this would include, for instance, a model of aqueous dissolution, how thermodynamic and/or kinetic aspects should be introduced in the model, what are the main processes to consider (e.g. hydrolysis, ion exchange, redox reactions), etc. This first step is fundamental since it controls the global structure of the model and the hierarchy of mechanisms and processes involved. The role of natural analogs is essential, and unique for long-term issues, in this qualitative activity.

Acquisition of data, definition of initial and boundary conditions: This is clearly important for the proper running of a proposed model. Analogs can be useful in this area, despite the fact that data are often difficult to extract from natural sites, because initial and/or boundary conditions are hard to estimate in the environment over geological time spans. This is both a qualitative and semi-quantitative activity.

Validation of models: This is a fundamental step when scientists want to convince themselves (and hence authorities and the lay public) that the model developed is pertinent and gives credible predictions of what should occur in a repository. Here, for the long-term, natural analogs are irreplaceable. Validation can be qualitative or quantitative. In the evaluation of the outputs of a model, orders of magnitude can be sufficient since, in safety assessment, one is merely interested in fixing upper limits.

Idachaba, M. A.; K. Nyvor; N. O. Egeibor; and R. D. Rogers. 2003. "Limitation of the NRC Method for Microbial Stability Evaluation of Waste Forms." Advances in Environmental Research Vol. 7, Issue 2, pp. 273-281.

This study is a critical evaluation of the NRC prescribed (10 CFR 61.56(b)(1)) accelerated test protocol for measuring the rates of microbial degradation of Class $\mathrm{B}$ and $\mathrm{C}$ low-level waste forms.

Iwaki, K., A. Hirama, K. Mitani, S. Kaise, K. Nakagawa. 2001. Technical Research Institute, Tobishima Corporation, Chiba, Japan., "A Quality Control Method for Shotcrete Strength by Pneumatic Pin Penetration Test,” NDT\&E International, 34(6), pp. 395-402.

Shotcrete is applied as a significant support element in tunneling because of its rapid strength development by adding accelerators. Thus the investigation of real shotcrete strength of tunnel 
lining is required for stabilization of excavation surfaces. Therefore, a pin penetration test using air pressure as the penetrating energy is proposed as a simple in situ test method. In this method, the penetration depth is used as an indication. Because of the close relationships between the penetration depth and wide range of compressive strength obtained from laboratory and field tests, the new testing method is considered effective for shotcrete. In addition, the application of this simple in situ test enables strength control to be undertaken with short intervals and to identify non-uniformity of the lining caused by accelerator dosage.

\section{Kleinlogel, A. 1960. “L’ Influence des Divers Elements Physicochimiques sur les Betons,” pp. 4-9.} Dunod, Paris.

Double- and triple-adding approaches also greatly increased the electrical resistance of concrete, which led to a delay in the initial time of corrosion and a decrease in the corrosion rate of steel bars. Additionally, double- and triple-adding mineral admixtures (instead of single additive) of fly ash can reduce the corrosion of steel bars when a large amount of fly-ash replacement is used.

\section{Kumar, Dheer, P. K. Behera, U. K. Singh. 2002. Res. Scholar, Mining Dep., Indian Inst. Technology, Kharagpur, India, "Shotcreting in Rock Excavation and its Adhesion Strength," Electronic Journal of Geotechnical Engineering (online computer file) 7. http://geotech.civen.okstate.edu/ejge/2002/Ppr0203/Ppr0203.htm}

In the present trend of support system used in underground coal mines, shotcrete is gaining wide acceptance, particularly in tunnel linings. The shotcrete support efficacy depends on the adhesion strength i.e., bonding between shotcrete and the rock surface. In order to determine the bond strength of shotcrete to the rock surface, an instrumental setup has been devised. The different coal measure rocks like shale, sandstone (coarse, medium, and fine grained) were acquired from various mines. A thorough laboratory study of adhesion of shotcrete to same rock with different surfaces roughness shows that roughness of the rock surface play a more significant role in bond strength, for a particular range of JRC between 8 and 17. For a particular range of JRC, bond strength is strongly correlated to JRC. The result also showed that tensile strength of rock has no relationship with bond strength. For a perfect bonding, min. setting time of shotcrete mixture is found to be 21 days. The use of some accelerating material becomes significant in order to achieve full bond strength at the earliest time. A minimum of five days is required for early setting of the shotcrete. The practical consequences of the investigation are also discussed.

\section{Lacroix, R. and P. Rossi. 2000. "BEFIM: The French National Project for the Industrial} Development of Metal Fiber Reinforced Concrete," RILEM Proceedings PRO 15, FiberReinforced Concretes (FRC), pp. 19-27.

A review on the studies involved in the French National Project for the industrial developments of metal fiber-reinforced concretes. Studies conducted include industrial slabs and airport runways, bored piles, tunnel supports and linings, the use of metal fiber-reinforced concrete in repair works, and precast products.

\section{Langmuir, D.1978. "Uranium Solution-Mineral Equilibrium at Low Temperatures with Applications to Sedimentary Ore Deposits." Geochimica et Cosmochimica Acta Vol. 42(6), pp. 547-569.}

Comprehensive review of Uranium groundwater chemistry and tabulation of thermodynamic data for U-oxide species as it pertains to solubility and the formation of ore bodies in sedimentary ore bodies. 
Longchen, L.; and I. Neretneiks. 2002. "A Reactive Transport Model for the Oxidative Dissolution of Spent Fuel and Release of Nuclides within a Defective Canister." Nuclear Technology Vol. 137 (3), pp. 228-240.

This study describes a detailed mechanism-based model of spent fuel dissolution in a oxidizing deep repository setting with canister and near field transport.

Malhorta, V. M.; V. S. Ramachandran; R. F. Feldman; and P-C. Aïtcin. 1986. Condensed Silica Fume in Concrete. CRC Press, Boca Raton, Florida.

This is a detailed monograph on the use of condensed silica fume in cementitious binders in concretes.

Malhotra, V. M.; H. S. Wilson, and K. E. Painter. 1989. "Performance of Gravel-Stone Concrete Incorporating Silica Fume at Elevated Temperatures," in the Proceedings of the Third International Conference, Trondheim, Norway, 1989, Volume 2, pp. 1051-1076, ACI publication SP114-51.

This paper reports performance of gravel-stone concrete incorporating $8 \%$ silica fume by weight of cement, after $72 \mathrm{~h}$ exposure at 150,300 , and $450^{\circ} \mathrm{C}$. Compression and flexural strength as well as weight loss and pulse velocity determinations were made before and after heat exposure for both the control mixture and the concrete containing silica fume. After $72 \mathrm{~h}$ at $150^{\circ} \mathrm{C}$, the strengths of control and silica fume concretes are not significantly different from the reference strength. At $300^{\circ} \mathrm{C}$, there is a moderate to significant loss depending upon the water to cement ratio used.

Marine Engineering Organization, UK 2004.

http://www.marineengineering.org.uk/motjktwtr/motcorinhibMain.htm

The metals closer to the anodic end of the list corrode with preference to the metals towards the cathode end cadmium. A galvanic cell can occur within an apparently homogeneous material due to several processes one of which is differential aeration where one area is exposed to more oxygen than another. The area with less oxygen becomes anodic and will corrode.

\section{Mattus C. H. and Gilliam T. M. 1994, A Literature Review of Mixed Waste Components: Sensitivities and Effects upon Solidification/Stabilization in Cement-Based Matrices. ORNL/TM-12656.}

In this literature study, Mattus and Gilliam found that by tailoring the formulation of the concrete, good retention of radionuclides were achieved by cement-based waste forms.

Mattus, C. H. and L. R. Dole. 2003. "Durability of Depleted Uranium Aggregates (DUAGG) in DUCRETE Shielding Applications,” International High-Level Radioactive Waste Management Conference, Las Vegas, NV, USA, American Nuclear Society, La Grange Park, IL USA, 03/30/2003-04/02/2003.

A study of the aging of basalt sintered $\mathrm{UO}_{2}$ in DI-water, $1 \mathrm{~N} \mathrm{NaOH}$, and cement porewater at $20^{\circ}$, $66^{\circ}$, and $150^{\circ} \mathrm{C}$ for up to 13 months. 
McCreath and Kaiser. 1992. "Evaluation of Current Support Practices in Burst-Prone Ground and Preliminary Guidelines for Canadian Hardrock Mines," Rock Support in Mining and Underground Construction, International Symposium on Rock Support (Sudbury), Kaiser and McCreath (Eds.), Balkema, Rotterdam, pp. 611-619.

McCreath and Kaiser suggest three main functions that a ground support system provides to the rockmass. These functions are to retain and hold a broken rock mass together, to provide reinforcement to help the rock mass support itself (Hoek and Brown 1980) and to strengthen the rock mass for control of swelling, and reduction of dilation and wall convergence.

\section{Moropoulou, A.; A. Bakolas, and S. Anagnostopoulou. 2004. "Composite Materials in Ancient Structures, Cement and Concrete Composites” (in press).}

Mortars and concretes employed in ancient structures concern composite materials which have exhibited excellent durability through time. They were used as lining materials in cisterns, wells, aqueducts, shafts and duct drains, as supporting materials for pavements and mosaics, as plasters on external and internal walls, as supporting materials for frescoes and as joint mortars on masonry structures. They were comprised of various binding materials (or mix of them) and natural or artificial aggregates, along with natural or artificial pozzolanic additions, primarily of volcanic origin, that improved their performance and prolonged their longevity. Moreover, various types of organic substances were employed to increase plasticity and regulate setting rates, while fibrous materials were commonly used to obtain greater strengths or to avoid cracks due to the shrinkage during setting. The comprehension of the production procedures employed and of the physico-chemical and mechanical characteristics of such composite materials can be achieved by integrating properly the results of various analyses. Data obtained from tests performed on a large number of historic composites sampled from ancient structures in the Mediterranean Basin permitted the identification of physico-chemical and mechanical characteristics of the most typical mortars encountered in ancient structures.

Nitao, John J.; and William E.Glassley. 1999. "Modeled Near-Field Environment Porosity Modification due to Coupled Thermohydrologic and Geochemical Processes. Materials Research Society Symposium - Proceedings, Vol. 556, pp. 705-711.

Heat deposited by waste packages in nuclear waste repositories can modify rock properties by instigating mineral dissolution and precipitation along hydrothermal flow pathways. Modeling this reactive transport requires coupling fluid flow to permeability modifications reflecting fracture and matrix porosity evolution resulting from dissolution and precipitation. Modification of the NUFT thermo-hydrologic code package to account for this coupling in a simplified geochemical system has been undertaken. The resulting capability was used to model the time dependent change in porosity, permeability, matrix and fracture saturation, and temperature in the vicinity of waste emplacement drifts, using conditions anticipated for the potential Yucca Mountain repository. The results show dramatic porosity reduction within a few hundred years, over a distance of about ten meters above emplacement drifts. Most of this reduction is attributed to deposition of solute load at the boiling front, although some of it also results from decreasing temperature along the flow path. The actual distribution of the nearly sealed region is sensitive to the time-dependent characteristics of the thermal load imposed on the environment, and suggests that the geometry of the sealed region can be engineered through management of the waste emplacement strategy and schedule.

These results demonstrate that porosity-reduction by silica deposition will modify hydrologic properties of the rock mass in the vicinity of waste-emplacement drifts. The time-dependent 
nature of these changes is complex. Periods of porosity reduction or enhancement can be followed by periods that reverse the nature of the change in porosity, depending upon heating histories and loading. These changes are of large magnitude and irreversible. Although the chemical system presented here is simplified, it likely represents a lower bound for the extent and magnitude of porosity reduction; with more complex chemistry, a wide range of mineral species with much larger molar volumes are likely to precipitate over a greater range of temperature and saturation conditions.

The parameters that exert the greatest control over mineral precipitation are temperature evolution and effective surface area. The former is an engineered property of the system and has the potential to be used to engineer the location and extent of mineral precipitation. The latter is an intrinsic and variable property of the rock system and needs to be better characterized to develop detailed, high-resolution models of high confidence.

The consequences of these results to repository performance may be substantial. Reduction in fracture aperture around the drifts may reduce seepage into the drifts. However, the actual threedimensional geometry of the sealed regions may be complex and uneven because of local inhomogeneity in hydrologic properties and mineral distributions along fractures. As a consequence, "dimples" in the sealed zone may possibly lead to perched condensate in some locations. Moreover, precipitation in the fractures will tend to be more extensive over regions of high refluxing (e.g., over hotter WPs) rather than over regions of low refluxing (e.g., over cooler WPs). Thus, variation in the spatial flux conditions caused by heating heterogeneity is potentially further increased by geochemical changes. These considerations emphasize the importance of considering geochemical changes when evaluating the performance implications of different engineering designs.

Oji, L. N. 2004. Condition Conducive to Forming Crystalline Uranyl Silicates in SRS Evaporators. WRSC-TR-2003-00553, Rev. 0.0, Westinghouse Savannah River Company, Aiken, SC.

This is a study of the hydrothermal conditions necessary to form insoluble uranyl silicates.

Onofrei, M., and M. Gray.1988. "The Effect of W/C Ratio and Cement Type on the Longevity of Grouts for Use in Nuclear Fuel Waste Vaults." Proceedings of the Materials Research Society Symposium in Boston, Massachusetts, November 28-30, 1988. MRS Proceedings Volume 137, "Pore Structure and Permeability of Cementitious Materials." L. R. Roberts and J .P. Skalny, Eds., Materials Research Society, Pittsburgh, Pennsylvania, pp. 359-367, 1989.

Canadian study verifies the results of OCED/NEA in the Stripa Mine, confirming that chemical changes in as a result with the interactions with the groundwater cause secondary alteration phases the influence the leaching processes. Also, greater durability is associated with the absence of $\mathrm{Ca}(\mathrm{OH})_{2}$ in the cement paste matrix.

Onofrei, M.; N.G. Malcom; L.D.Keil; and R. Pusch. 1989. "Studies of Cement and Grouting Techniques for Sealing a Nuclear Waste Disposal Vault." Proceedings of the Materials Research Society Symposium in Boston, Massachusetts, November 28-30, 1988. MRS Proceedings Volume 137, "Pore Structure and Permeability of Cementitious Materials." L.R. Roberts and J.P. Skalny, Eds., Materials Research Society, Pittsburgh, Pennsylvania, pp. 349-358, 1989. 
Canadian study verifies the results of OCED/NEA in the Stripa Mine, confirming that the addition of silica fume reduced the hydraulic conductivity and increased the matrix's ability to heal small fractures.

\section{Parker, Harvey; Paul Godlewski; and Roberto Guardia. 2002. "The Art of Tunnel Rehabilitation with Shotcrete,' Shotcrete, pp. 14 - 18, Fall.}

One of the advantages of tunnels is that they inherently last much longer and require less maintenance than other infrastructures. The authors have rehabilitated several tunnels that were over a century old, allowing these tunnels to begin their second century of service. This long life represents a huge life-cycle benefit for the tunnel owner, and this cost advantage can be maintained by conducting an occasional rehabilitation from time to time. The increase in the number and type of tunnels being rehabilitated over the last few decades was largely made possible by the continued development of ground support methods using rock bolts and steel fiber-reinforced shotcrete.

The use of steel fiber-reinforced shotcrete made the rehabilitation of railroad and highway tunnels practical and economically viable. The strength and durability of steel fiber micro-silica shotcrete in combination with tensioned or un-tensioned anchor bolts can handle almost any type of tunnel ground loading. Shotcrete can be installed utilizing the wet or dry methods and can be installed to sculpt any tunnel shape without the use of costly forms or the need for rebars or mesh. No matter whether 10 or $1000 \mathrm{y}^{3} / \mathrm{m}^{3}$ of shotcrete are required, there is always an economical method of providing and installing quality and durable shotcrete.

\section{Petit, J-C. 1992a. "Natural Analogs for the Design and Performance Assessment of Radioactive Waste Forms: A Review.” Journal of Geochemical Exploration 46, pp. 1-33.}

This paper shows that reasoning by analogy plays a very important role in the process of scientific discovery, which is fully acknowledged by numerous studies in the history and sociology of science. It is just the only means at hand for obtaining unique qualitative and, in some cases, quantitative information on systems of equivalent complexity to a nuclear waste repository, and for periods of time not accessible to laboratory or in situ experiments. It must be used with caution and only in conjunction with laboratory and in situ experiments as well as with modeling.

It has been recognized very quickly that long-term extrapolations concerning the safety of a nuclear waste repository cannot be satisfactorily made on the sole basis of short-term laboratory investigations. Most nuclear countries have hence developed an approach relying on the following research directions:

- Laboratory experiments, which allow the identification of individual mechanisms (in particular "rapid" ones) and the quantitative evaluation of the influence of particular parameters in well-designed controlled systems.

- In situ testing, which permits the investigation of ruling mechanisms or global phenomena in a medium-scale system of appropriate complexity but only on the short term.

- Modeling, which, in spite of the often necessary relative simplification of the system components and functions, allows the rational extrapolation of short-term data to much longer periods of time. 
- Natural analogs, which are the only means by which very slow mechanisms can be identified and which can test long-term predictions of models for pertinence (if not truly validated). Among the pioneers of this field are Brookins (1976), Ewing (1979), and more recently Chapman et al. (1984).

\section{Petit, J-C. 1992b. "Reasoning by Analogy: Rational Foundation of Natural Analog Studies." Applied Geochemistry Supplementary Issue No. 1, pp. 9-11.}

Good analogs suggest that, while their use has been quite limited in the past for the design of matrices, both qualitative and quantitative information of great (and in some cases unique) interest has already been inferred for assessing their long-term performance.

Several historical and archaeological cements (notably Roman and Gallo-Roman cements) have been studied as analogs of cement-based matrices (Jull and Lees, 1990). Although most of these materials were made with a different technology to that used nowadays, similar constituents (hydrated calcium silicates, ettringite, etc.) can be found.

Some work has been reported on both old cements, with a maximum age of 150 years, and archaeological binders with ages up to about 2,000 years (Steadman, 1986; Jull and Lees, 1990). The analogy of such binders with modem cement is, in most cases, very poor, but there are some instances where the major constituents of modern cement (calcium hydrosilicates labeled CSH, ettringite, etc.) have been formed, due to specific conditions of cement preparation. This is found in particular where binders have been made up of fired clays, volcanic rocks (e.g., pozzolans), etc., which introduce both silicon and aluminum to the system. In these cases, silicates, silicaaluminates, and possibly aluminates, could form during the setting of the binders and the analogy between archaeological artifacts and modern cement is then worth studying.

Two investigations can best illustrate the use of natural analogs for assessing alteration processes. The first has been conducted on samples collected from Hadrian's Wall, in the north of England (Jull and Lees 1990), and the second in Gallo-Roman baths from the southwest of France (Rassineux et al. 1989). These studies have confirmed that, on the long-term, the carbonation of hydrosilicates is the main mechanism of alteration of binders. Indeed, whenever $\mathrm{CO}_{2}$ has access to the material, CSH can rapidly transform into calcite throughout the bulk. This process is enhanced by the presence of fissures.

The evolution of CSH over 1800 years could also be determined. It was commonly thought that such amorphous substances would organize with time and transform into crystalline minerals, such as their natural counterparts (tobermorite, gyrolite, etc.), which are high-temperature alteration products of basic and ultra-basic rocks. From a purely thermodynamic point of view, this is conceivable, but these archaeological analogs show that this transformation does not occur over this time span, probably because of its slow kinetics.

Analogs also suggest that the higher the $\mathrm{SiO}_{2} / \mathrm{CaO}$ ratio the higher the stability of the $\mathrm{CSH}$, which exhibits no evidence of crystallization or better organization.

Petre-Lazar, L. Abdou, C. Franco, and I. Sadri. 2003. “THI - Model for Estimating the coupled Transport of Heat, Moisture, and Chloride Ions in Concrete." Proceedings of the 2nd International Workshop on Life Predication and Aging of Management of Concrete Structures. Paris, France, May 5-6, PRO 29, RILEM Bagneux, France, pp. 51-69. 
There are physical-chemical models that couple the transport of water, chloride, and heat that can be conservative predictors of cement aging. These models reproduce well some data observed in situ exposures.

\section{Phan, L. T. et al. 2002. "High-Strength Concrete at High Temperature - An Overview," International Symposium on Utilization of High-Strength, High-Performance Concrete, June 16-20, Leipzig, Germany.}

This paper presents results of NIST experimental program on the effects of elevated temperature exposure on the mechanical properties and potential for explosive spalling of high strength concrete (HSC). Mechanical properties of HSC were measured by heating $100 \times 200 \mathrm{~mm}$ cylinders at $5^{\circ} \mathrm{C} / \mathrm{min}$ to temperatures of up to $600^{\circ} \mathrm{C}$, and heat-induced pore pressure buildup was measured by heating $100 \times 200 \times 200 \mathrm{~mm}$ blocks to the same temperature level at the same heating rate. The results of NIST mechanical property measurement are compared with results obtained in other studies as well as with existing code provisions to evaluate their applicability to HSC. The paper also presents results of measurement that indicate the efficacy of polypropylene fibers for mitigation of explosive spalling.

Pinheiro, S. M. de Mores, and M. R. Silva. 2003, PRO 34, "Alteration of Concrete Microstructure by Biodeterioration Mechanisms.” Proceedings of the International RILEM Conference on Microbial Impact on Building Materials, September 8-9, 2003, Lisbon, Portugal. M.R. Silva, Ed. RILEM Publications, S.A.R.L., Bagneux, France, pp. 48-57.

This study describes the interaction of the cement-paste microstructure with colonies of Cladosporium sphaerospermum fungus. This describes techniques for inoculation and the conservation of the samples for analysis.

PQ Quartz. 2004. Bulletin 37-3, "PQ® Soluble Silicates: For Protection of Water Systems From Corrosion.” P.O. Box 840, Valley Forge, PA 19482-0840.

Soluble silicates are economical, effective, and environmentally responsible chemicals, which have been used for more than 70 years to protect metals from the corrosive effects of water. They are classified as corrosion inhibitors because they can deposit protective films onto various metal surfaces, isolating the metal from any further corrosive attack.

Prikryl, James D.; Alka Jain; David R. Turner; Roberto; and T. Pabalan. 2001. “UraniumVI Sorption Behavior on Silicate Mineral Mixtures,” Journal of Contaminant Hydrology, 47, pp. 241-253.

An example of a case where the ad/absorption of U(VI) on to silica-rich surfaces without silica in the leachate, these data from sorption experiments on quartz at atmospheric $p \mathrm{CO}_{2}$ conditions (Prikryl et al. 2001) were used to derive U(VI) binding constants for a diffuse-layer surfacecomplexation model DLM (Davis and Kent 1960). The DLM was then used with surface area as a scaling factor to predict sorption of $\mathrm{U}(\mathrm{VI})$ onto clinoptilolite and clinoptilolite/quartz mixtures under both atmospheric and low $p \mathrm{CO}_{2}$ conditions (Prikryl et al. 2001). The calculations reproduced many aspects of the $\mathrm{pH}$-dependent sorption behavior. If this approach can be demonstrated for natural mineral assemblages, it may be useful as a relatively simple method for improving radionuclide transport models in performance-assessment calculations. 
Uranium(VI) sorption experiments involving quartz and clinoptilolite, important mineral phases at the proposed U.S. nuclear waste repository at Yucca Mountain, NV, were conducted to evaluate the ability of surface complexation models to predict U(VI) sorption onto mineral mixtures based on parameters derived from single-mineral experiments (Prikryl et al. 2001).

The data how that $\mathrm{U}(\mathrm{VI})$ sorption on clinoptilolite, quartz, and clinoptilolite/quartz mixtures is strongly influenced by solution $\mathrm{pH}$. In experiments, conducted at atmospheric $p \mathrm{CO}_{2}, \mathrm{U}(\mathrm{IV})$ sorption reaches a maximum at near-neutral $\mathrm{pH}=6.0$ to 6.5 , and then decreases toward more acidic and more alkaline conditions. Under low- $p \mathrm{CO}_{2}$ conditions, $\mathrm{U}(\mathrm{VI})$ sorption increases with increasing $\mathrm{pH}$ up to about 6.0, then remains relatively constant with further increases in $\mathrm{pH}$. Notably, the $\mathrm{pH}$ dependence of $\mathrm{U}(\mathrm{VI})$ sorption is similar regardless of the relative proportion of clinoptilolite to quartz.

Results of the U(VI) sorption experiments are cast in terms of the distribution coefficient $K_{d}$ vs. $\mathrm{pH}$.

Ratcliffe, R. 1999. Scancem Materials (Australia) Pty Ltd, Osborne Park, WA, USA., "The Important Properties of Steel Fiber Reinforced Shotcrete (SFRS) Used in Mining," Publications of the Australian Institute of Mining and Metallurgy, 10th Australian Tunneling Conference 2/99, pp. 133-140.

This is a review with 10 references. The reasons for using SFRS, including the way a SFRS performs in comparison to plain shotcrete as a support element in mining tunnels, are discussed. The mechanisms by which steel fibers reinforce shotcrete and the need for specifying performance criteria are highlighted. A description of current testing procedures, including an overview of 'quant.' design recommendations provided from various international authorities, is provided. A summary of international recommendations on suitable 'qual.' performance classifications is also reviewed, including a critique of their suitability. Finally,recommendations on the practical considerations necessary to ensure good quality, in-place SFRS are made, including a calculation method for determining minimum steel fiber dosages.

\section{Rogers, R. D.; J. J. Knight; C. R. Cheeseman; J. H. Wolfram; M. Idachaba; K. Nyavor; and N. O. Egeibor. 2003. "Development of a Test Method for Assessing Microbial Influenced Degradation of Cement-Solidified Radioactive and Industrial Wastes." Cement and Concrete Research 33, pp. 2069-2076.}

This study develops an improved methodology for the accelerated testing of biodegradation of cementitious materials. It discusses the development of accelerated tests for evaluating microbial influenced degradation (MID) of cement-solidified wastes. An existing U.S. Nuclear Regulatory Commission (NRC) accelerated test cannot distinguish between degradation caused by biogenic acid produced under optimal conditions in a bioreactor and that caused by active biofilms formed on the waste materials. Nutrient limitations were also observed that would significantly limit the activity of any developing biofilm. Results from this work have shown that it is possible to modify this test to remove nutrient limitations and enable the effects of MID resulting from active biofilms to be examined.

Mineral acid production by T. thiooxidans can promote cemented waste form degradation comparable to that of media amended with sulphuric acid. 
The existing NRC accelerated microbial degradation test cannot distinguish between degradation caused by biogenic acid produced under optimal conditions in a bioreactor and that caused by active biofilms formed on the waste materials.

Nutrient limitations in the NRC test would significantly limit the activity of any developing biofilm and the effects of waste components on biological acid generation cannot be examined with this test. It is necessary to establish free growing biofilm on the waste forms before the effects of MID can be determined.

A more realistic modified NRC test was proposed with separate biofilm formation and biofilm evaluation stages. The test removed nutrient limitations on biofilm growth and enabled the effects of MID resulting from active biofilms growing on waste forms to be examined. Aggressive MID microorganisms ( $\mathrm{T}$. thiooxidans) can form a biofilm on the surface of cement-solidified waste so that when nutrients are provided the microbes remain active.

Rosato, V. G. and L. P. Traversa. 2000. "Lichen Growth on a Concrete Dam in a Rural Environment (Tandil Buenos Aires Province, Argentina).” PRO 20, Proceedings of the July 6-7, 2000, First International RILEM Workshop on Microbial Impacts on Building Materials, São Paulo, Brazil, Ed. R. Silva. RILEM Publications, S.A.R.L., Bagneux, France, No. 8, 2000.

Lichen only grows on OPC surfaces after a period of exposure to $\mathrm{CO}_{2}$ in the atmosphere that carbonizes the concrete surface and seals the lichen from the Portlandite embedded in the cement paste matrix.

Rosenberg, N. D.; G. E. Gdowski; and K .G. Knauss. 2001. "Evaporative Chemical Evolution of Natural Waters at Yucca Mountain, Nevada.” Applied Geochemistry 16, pp. 1231-1240.

This is a study of the compositions of Yucca mountain groundwaters, Well J13 and the unsaturated zone as they are evaporated to dryness.

Sodium, $3.9 \times 10^{-3}-2.0 \times 10^{-3} \mathrm{M} \mathrm{Na}(+\mathrm{a})$, and carbonate, $1.1 \times 10^{-3}-2.1 \times 10^{-3} \mathrm{M} \mathrm{HCO}_{3}(-\mathrm{a})$, concentrations are found in the YM groundwater.

Roy, D. M. and B. E. Scheetz. 1992. "The Chemistry of Cementitious Systems for Waste Management: The Penn State Experience.” Chapter 3, Chemistry and Microstructure of Solified Waste Forms, Ed. R.D. Spence, Lewis Publishers, Ann Arbor, MI, pp. 83-101.

This paper reports the work of Hoyle, who established the $\mathrm{CaO}-\mathrm{SiO}_{2}-\mathrm{Al} 2 \mathrm{O} 3$ positional relationships that prevent Portlandite formation.

Saito, Hiroshi and Akira Deguchi. 2000. "Leaching Tests on Different Mortars Using Accelerated Electrochemical Method.” Cement and Concrete Research 30, pp. 1815-1825.

The characteristics of the cement hydrate structure reflect differences in mix proportions and pozzolanic admixture. In particular, pozzolanic admixture replacement decreases $\mathrm{Ca}(\mathrm{OH})_{2}$ content to from a tight cement hydrate structure. Pozzolanic admixture replacement for a part of the cement is very useful for mix proportion design of a durable concrete that resists leaching and shows small loss of performances after leaching. 
Saito and Deguchi measured the effects of granulated blast furnace slags on the distribution of pore sizes in mortars (only fine aggregate).

After electrolytic, accelerated leaching, the water permeability in the surficial, degraded region of mortar specimens increased by about two orders of magnitude in the nonreplacement test (i.e., without pozzolans), but by only one order of magnitude in test samples with pozzolans. The water permeabilities in the un-degraded region in both test series remained the same because of the small increase in pore volume due to dissolution of the cement hydrate. Therefore, the replacement of cement with pozzolanic admixtures reduces the increase in the mortars' water permeabilities.

\section{Shoesmith, D. W. 2000. "Fuel Corrosion Processes Under Waste Disposal Conditions," Journal of Nuclear Materials, 282, pp. 1-31.}

Assuming the ions are incorporated into U(VI) deposits with very low solubilities, the rapidity of the reduction of the corrosion rate by the addition of $\mathrm{Ca} / \mathrm{Si}$ indicates that very little of these silica phases is required to suppress corrosion. This is consistent with electrochemical experiments which show that the incorporation of $\mathrm{Ca} / \mathrm{Si}$ into $\mathrm{U}(\mathrm{VI})$ surface phases is very rapid and that only a few nm can suppress uranium oxide substantially. Corrosion experiments in the presence of $\gamma$ radiation fields show that the accumulation of secondary phases begins as soon as steady-state corrosion conditions are established.

Beyond this transient period, a dense mat of alteration phases developed on the fuel surface, accompanied by depletion in the alkali and alkaline earth cations and $\mathrm{Si}$ in the leachate solution. The nature of these alteration phases and the sequence in which they appear on the fuel are similar to those observed in surficial weathering zones of natural uraninite deposits, with alkali and alkaline earth uranyl silicates being the long-term solubility limiting phases for uranium. The formation of this layer of alteration (or corrosion) products prevents further release of $\mathrm{UO}_{2}$ particles, hence leading to a drop in the $\mathrm{U}$ release.

Sonnenberg, E. L. and G.S. Bodvarsson. 1999. "Constraints on the Hydrology of the Unsaturated Zone at Yucca Mountain, Nevada from Three-Dimensional models of Chloride and Strontium Geochemistry." J. Contam. Hydrol. 38 (1-3), pp. 107-156.

The formation above the repository horizon is an unfractured tuff, the Paintbrush hydrostratographic unit and a welded unit of the Tonopah Springs Tuff.

Soroka, I. 1980. Portland Cement Paste and Concrete. Chapter 5, "Volume Changes in the Hardened Paste.” Chemical Publishing Co., Inc., NY, pp. 102-144.

Chapter 5 includes a discussion of pore size control of vapor pressure in the context of wet-dry cycles and the texture of the cement-paste texture.

Sowder, A. G.; S. B. Clark; and R. A. Field. 1996. "The Effect of Silica and Phosphate on the Transformation of Schoepite to Becquerelite and Other Uranyl Phases." Radiochimica Acta 74, 45-49.

The influence of silica and phosphate on schoepite weathering in calcium bearing systems has been examined. The presence of $\mathrm{Si}\left(10^{-3} \mathrm{M}\right)$ retarded the transformation of schoepite to becquerelite in $10^{-2}$; and $10^{-3} \mathrm{M}$ Ca systems as compared to silica free systems. The formation of uranyl silicates was not observed. The presence of phosphate $\left(10^{-2} \mathrm{M}\right)$ in a $10^{-3} \mathrm{M}$ Ca system led 
to the transformation of schoepite into autunite via several intermediate products, including becquerelite and one or more uranyl phosphates. These results indicate the importance of silica and phosphate in the transformation of secondary uranyl phases in natural systems.

Spence, R. D.; T. M., Gilliam; I. Morgan; and S. C. Osborne. 1992. "Stabilization/Solidification of Wastes Containing Volatile Organic Compounds in Commercial Cementitious Waste Forms, Stabilization and Solidification of Hazardous, Radioactive, and Mixed Wastes." Vol. 2, ASTM STP 1123, T. M. Gilliam and C. C., Wiles, Eds., American Society for Testing and Materials, Philadelphia, pp. 61-72.

This study measured diffusion coefficients of small organic molecules in cement pastes. The diffusion coefficient s for small organic molecules were $\sim 1 \times 10^{-6} \mathrm{~cm}^{2} / \mathrm{s}$ for chloroform, $\sim 3.5 \times$ $10^{-8} \mathrm{~cm}^{2} / \mathrm{s}$ for acetone, 1,2-dichloroetylene and benzene, and $\sim 3 \times 10^{-9} \mathrm{~cm}^{2} / \mathrm{s}$ for chlorobenzene and percloroethene.

Sun, W.; Y. Zhang; S. Liu; and Y. Zhang. 2004. "The Influence of Mineral Admixtures on Resistance to Corrosion of Steel Bars in Green High-Performance Concrete," Cement and Concrete Research (in press).

Fly ash reduced the corrosion of steel bars when a large replacement for OPC was used (Sun 2004). Silica mineral admixtures greatly increased the electrical resistance of concrete, which delayed the initial corrosion time of steel bars and a decrease of the steady-state corrosion rate. The results of electrochemistry and immerging-drying cycle tests indicated that single-adding silica fume or double- and triple-adding mineral admixtures possessed a superior resistance to the steel corrosion in high performance concretes.

Zadeh, M. S., G. Debicki, P. Clastres, and Y. Billard. 1998. "Influence of Silica Fumes on Permeability of Concrete to Oxygen for Temperatures up to $500^{\circ} \mathrm{C}$," in Sixth CANMET / ACI JCI International Conference, Volume 2, pp. 975-996; ACI SP 178-50.

High-performance concretes incorporating silica fume are increasingly used for the construction of nuclear reactor containment wall susceptible to accident conditions. This paper deals with the influence of the silica fume dosage rate on the permeability coefficient for temperatures ranging from room temperature to $500^{\circ} \mathrm{C}$. The use of silica fume reduces the oxygen permeability of concrete by 2 to 3.6 times at room temperature. The advantage of the silica fume addition to decrease the loss of leak tightness integrity depends strongly on the use of the optimum dosage rate of silica fume (i.e., 6-7\% in these tests). The authors found that for temperatures up to $105^{\circ} \mathrm{C}$, the capillary and adsorbed water losses causes increase permeability, while for the temperature interval $105-200^{\circ} \mathrm{C}$ is due to porosity evolution, and for higher temperatures up to $500^{\circ} \mathrm{C}$ losses of leak-tightness and integrity of concrete is induced by micro cracking propagation during heating. 